\title{
Agrupaciones
} heterogéneas $e$ intervención en arquitecturas existentes

TESIS DOCTORAL VÍCTOR NAVARRO RIOS, ARQUITECTO 

DEPARTAMENTO DE PROYECTOS ARQUITECTÓNICOS ESCUELA TÉCNICA SUPERIOR DE ARQUITECTURA DE MADRID

\section{Agrupaciones heterogéneas e intervención en arquitecturas existentes}



Tribunal nombrado por el Mgfco. Y Excmo. Sr. Rector de la Universidad Politécnica de Madrid, el día

Presidente D.

Vocal D.

Vocal D.

Vocal D.

Secretario D.

Realizado el acto de defensa y lectura de Tesis el día en la Escuela Técnica Superior de Arquitectura de Madrid

Calificación:

EL PRESIDENTE

LOS VOCALES

EL SECRETARIO 



\section{Agradecimientos}

Son muchas la personas que han ayudado y han contribuido a que esta tesis sea posible. Tantas y en tantos momentos que sería imposible nombrar a todas. A ellas mi máximo agradecimiento.

Quiero reconocer especialmente y dedicar esta tesis

a Emilio Tuñón por aceptar el reto de dirigir esta investigación y por su guía en todo el proceso.

a Sofía Blanco por ayudarme a bucear en los fondos de la Universidad de Harvard.

a Ángela Juarranz por su inagotable y entusiasta ayuda, cualquier agradecimiento es poco.

a Jesús y Pilar, también a mis padres.

a María por mucho más de lo que puede imaginar.

a Darío. 



\section{RESUMEN}

Esta tesis doctoral profundiza, dentro del campo de la práctica del proyecto arquitectónico, en aquellas técnicas proyectuales que al intervenir sobre lo ya construido son capaces de cambiar su valor y su significado.

La investigación tiene como objetivo demostrar que es posible revertir la obsolescencia de las arquitecturas ordinaras existentes mediante una técnica proyectual que hemos llamado agrupaciones heterogéneas. En ellas, la preexistencia y lo aportado inauguran un tiempo de convivencia que obliga a reinterpretar a la primera mientras que la segunda es forzada a traducir sus imaginarios.

Esta investigación se conecta con el mundo del conocimiento a través de dos vectores, uno que lo enlaza con el estudio de las agrupaciones heterogéneas y otro con la intervención sobre arquitecturas ordinarias. Para el desarrollo de los trabajos, en una primera parte, se ha procedido al análisis de cada campo por separado a través del estudio de casos concretos: la plastic furniture de Charles y Ray Eames para el caso de las agrupaciones heterogéneas y el libro-manifiesto Plus de Frédéric Druot, Anne Lacaton y Jean-Philippe Vassal para la intervención sobre arquitecturas ordinarias. En cada estudio hemos obtenido unas conclusiones parciales: la arquitectura entendida como estado de encuentro y la teoría de la resistencia a los imaginarios. La segunda parte de la tesis toma el proyecto de Frank Gehry para su casa en Santa Mónica como un ejemplo en el que se ha revertido con éxito la obsolescencia de una arquitectura ordinaria a través de la técnica de las agrupaciones heterogéneas. A partir de ese ejemplo, y bajo la perspectiva de los dos campos estudiados, se propone una cartografía teórica para leer los procesos de innovación que tienen lugar al utilizar esta estrategia en diseño del proyecto. 



\section{ABSTRACT}

This PhD thesis will provide an in-depth view of the techniques in practice in architectural projects, with proposals that are able to change the value and meaning of work that has already been built.

The research is aimed at proving that it is possible to revert the obsolescence of the existing ordinary architecture using a project technique that we have called "heterogeneous ensembles". In these ensembles, what existed beforehand and what has been contributed afterwards have brought about a new form of co-existence which forces the former to be reinterpreted and the latter to clarify its archetypes.

This research connects to the world of knowledge through two vectors: one which links it to the study of the beterogeneous ensembles and the other to the work carried out on the ordinary architecture. To carry out this work, firstly we analysed each field separately by studying specific cases: the Charles and Ray Eames plastic furniture for the heterogeneous ensembles and the book and manifesto Plus by Frédéric Druot, Anne Lacaton and JeanPhilippe Vassal for the work carried out on the ordinary architecture. We drew partial conclusions in each study: architecture understood as a state of encounter and the theory of resistance to the archetypes. The second part of the thesis takes Frank Gehry's project for his Santa Monica house as an example in which the obsolescence of ordinary architecture has been successfully reverted using the heterogeneous ensembles technique. Based on this example and from the standpoint of the two fields in question, we propose a theoretical cartography to read the innovation processes that take place when using this strategy in project design. 



\section{ÍNDICE DE LA TESIS}

INTRODUCCIÓN I

INTRODUCCIÓN III

RESUMEN DE CAPITULOS $\quad$ VII

ALGUNOS CONCEPTOS XI

Túneles del tiempo $\quad \mathrm{XI}$

Energías cautivas $\quad X I I$

$\begin{array}{ll}\text { Economía cultural } & X V\end{array}$

Innovación por desplazamiento $\quad$ XVII

\section{PARTE I}

1. AGRUPACIONES HETEROGÉNEAS: LA PLASTIC FURNITURE DE CHARLES Y RAY EAMES

$1.1 \quad$ UNA SILLA, UNA ARQUITECTURA

1.2 UNA SILLA ORDINARIA

$\begin{array}{lll}1.3 & \text { PLASTIC FURNITURE: LAS SILLAS-MUNDO } & 17\end{array}$

1.4 COMBINACIÓN Y MONTAJE: LANGUAGE OF VISION 29

1.5 LA PLASTIC FURNITURE COMO ESTADO DE ENCUENTRO 41

1.5.1 Dimensión experiencial: la percepción dinámica del objeto 43

1.5.2 Dimensión pública: la espacialización de la seducción 49

1.5.3 Dimensión performativa: la silla como proceso abierto 51

1.5.4 Dimensión relacional: la confluencia de universos 55

1.5.5 Dimensión mestiza: la silla como conflicto 

2. INTERVENCIÓN EN ARQUITECTURAS EXISTENTES: PLUS DE DRUOT, LACATON \& VASSAL 65

$\begin{array}{lll}2.1 & \text { RESISTENCIAS } & 67\end{array}$

2.2 RAZONES DE LA PRESERVACIÓN

2.2.1 La aproximación cualitativa 73

2.2.2 La aproximación cuantitativa

2.3 PLUS: UN MANIFIESTO

2.3.1 Principios Plus 87

2.3.2 Suspensión del juicio $\quad 91$

2.3.3 Economía cualitativa $\quad 95$

2.3.4 Desplazamiento de imaginarios 99

$\begin{array}{lll}2.4 & 111\end{array}$

2.4.1 Shearing Layers of Change 113

2.4.2 El caso Bois-le-Prêtre $\quad 119$

$\begin{array}{lll}2.5 & \text { TEORÍA DE LA RESISTENCIA A LOS IMAGINARIOS } & 127\end{array}$

\section{PARTE II}

3. TRANSMUTACIÓN DE VALOR Y SIGNIFICADO: LA CASA DE GEHRY EN SANTA MÓNICA 137

$\begin{array}{lll}3.1 & \text { AMUEBLAR EL MUNDO } & 139\end{array}$

$\begin{array}{lll}3.2 & \text { DE LA CASA-ROSA A LA CASA-GEHRY } & 147\end{array}$

3.2.1 La casa-rosa 153

3.2.2 La casa-Gehry 159

3.3 LA TOTALIDAD-CASA COMO ESTADO DE ENCUENTRO 185

3.3 RESISTENCIA A LOS IMAGINARIOS EN LA CASA DE SANTA MÓNICA 195

3.5 CARTOGRAFÍA DE LA INNOVACIÓN. GUÍA DE DESPLAZAMIENTOS 203

\begin{tabular}{lr} 
4. & CONCLUSIONES \\
\hline
\end{tabular}

$\begin{array}{lr}\text { 5. BIBLIOGRAFÍA } & 227\end{array}$ 

INTRODUCCIÓN 

El arte es un juego entre los hombres de todas las épocas.

Marcel Duchamp

Lo nuevo es insoslayable, inevitable, irrenunciable.

Boris Groys

\section{INTRODUCCIÓN}

Toda construcción es un cuerpo en transición sometido a la entropía, el tiempo consume su memoria y degrada su materia. Si queda desatendida acabará por no ser nada, por no dejar huella. La comunidad planetaria, conocedora de la irreversibilidad de ese proceso, ha concebido instituciones y ha propuesto jerarquías de valor para seleccionar y organizar la preservación de esas construcciones según criterios de significación. ${ }^{1}$ La humanidad, consciente de que algunas arquitecturas son capaces de concentrar la identidad y las aspiraciones de toda una cultura, se ha esforzado en catalogarlas y conservarlas. En cambio, las excluidas son recibidas con indolencia y relegadas a un destino incierto.

A esa masa construida que la disciplina de la arquitectura proclama fuera de su territorio y contra la que define sus límites la denominamos lo ordinario ${ }^{2}$, un término elástico que reúne todo aquello que no queda protegido ni inventariado por los archivos de la cultura. Ese conjunto edificado, que se acepta con resignación y se mira con indiferencia, supera con mucho la suma de los proyectos que maneja y custodia la disciplina. Es la textura de nuestras ciudades y donde se construye el día a día. 


\section{AGRUPACIONES HETEROGÉNEAS}

\section{INTERVENCIÓN EN ARQUITECTURAS EXISTENTES}

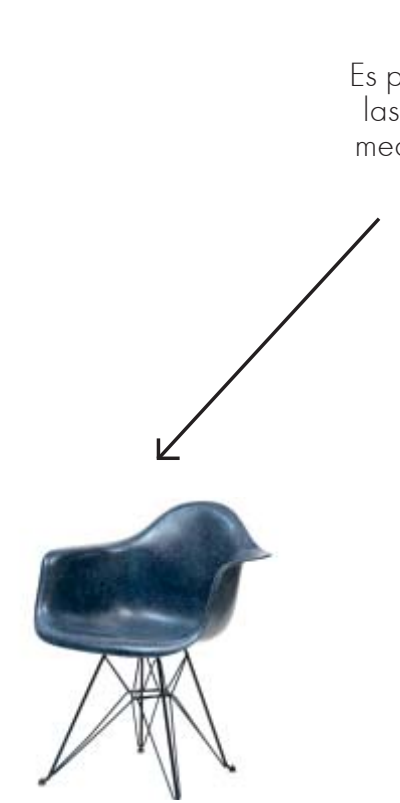

HIPOTESIS DE PARTIDA

Es posible revertir la obsolescencia de as arquitecturas ordinaras existentes mediante la técnica proyectual de las agrupaciones heterogéneas.

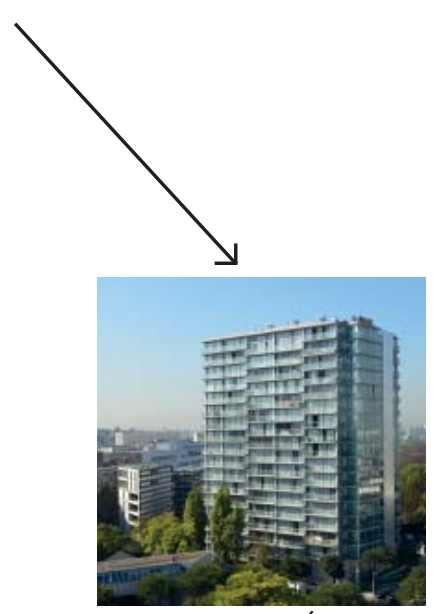

2. INTERVENCIÓN EN

1. AGRUPACIONES HETEROGÉNEAS ARQUITECTURAS EXISTENTES

PLUS y Bois-le-Prêtre

Plastic Furniture

Charles y Ray Eames, 1950

Druot, Lacaton y Vassal, 2007

\section{ARQUITECTURA COMO ESTADO DE ENCUENTRO}

TEORIAA DE LA RESISTENCIA A LOS IMAGINARIOS
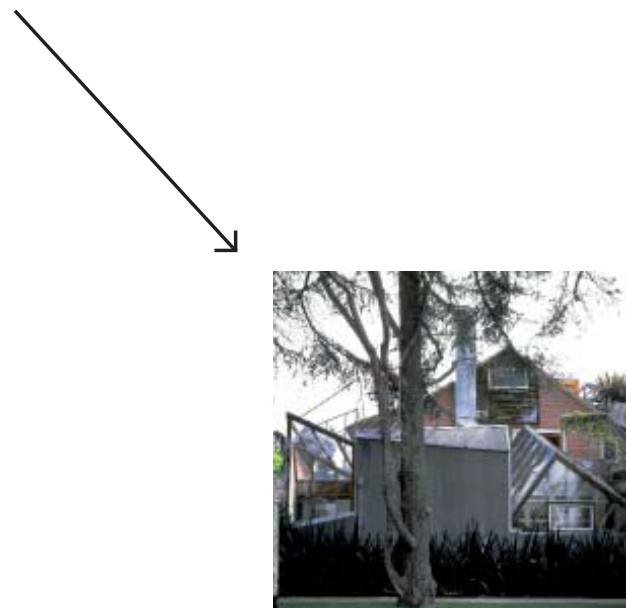

3. TRANSMUTACIÓN DE VALOR Y SIGNIFICADO

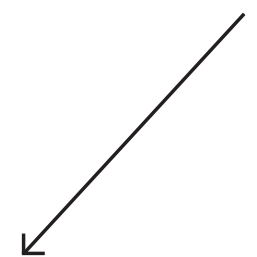

Residencia de la familia Gehry Anónimo, 1920s

Frank Gehry, 1978, 1994

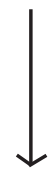

CARTOGRAFÍA DE LA INNOVACIÓN: GUÍA DE DESPLAZAMIENTOS 
Tarde o temprano todas esas arquitecturas ordinarias acaban por caer en un estado de obsolescencia. Su devaluación empieza como un distanciamiento entre lo construido y sus expectativas y culmina con un desprecio por su ineficaz desempeño de funciones. A lo largo de la historia lo habitual ha sido revertir el agotamiento de esa materia mediante la adaptación y la reapropiación. Sin embargo, durante el siglo XX y promovido por el ideario moderno se optó por el derribo masivo y la sustitución. Este planteamiento entró en crisis debido a su fuerte impacto en el medio ambiente y el alto consumo de recursos. Los modelos de desarrollo sostenible advirtieron de la necesidad de reutilizar y reciclar esa ciudad anodina a la que la arquitectura no prestaba atención. Fueron otros agentes como ingenierías, fabricantes y promotores los que, bajo posicionamientos exclusivamente cuantitativos, tomaron la iniciativa.

No ha sido hasta entrado en siglo XXI que desde algunas prácticas de nuestra disciplina se ha reclamado ese territorio para la arquitectura y se han propuesto liderar su transformación. Cada vez son más numerosos los ejemplos construidos que merecen atención y no son pocos los que ya se han convertido en paradigmáticos. Sin embargo, la producción de textos críticos que analicen estas experiencias no ha seguido la misma progresión. Esta tesis pretende ocupar parte de ese vacío y ampliar el conocimiento sobre las prácticas del proyecto arquitectónico que operan en ese campo.

Nuestra investigación analiza y evalúa una parte concreta de esta producción: las agrupaciones heterogéneas. Desde un punto de vista genérico estas arquitecturas son el resultado de la coexistencia de dos o más sistemas diferenciados entre los que se manifiesta una tensión. Nos ocuparemos concretamente del resultado de su aplicación sobre una arquitectura existente. A partir del estudio de tres casos concretos profundizaremos en los diferentes campos involucrados en la investigación: la plastic furniture de Charles y Ray Eames para el caso de las agrupaciones heterogéneas y el libromanifiesto Plus de Frédéric Druot, Anne Lacaton y Jean-Philippe Vassal para la intervención sobre arquitecturas ordinarias. Por último tomaremos como ejemplo en el que se ha revertido con éxito la obsolescencia de una arquitectura ordinaria a través de la técnica de las agrupaciones heterogéneas el proyecto de Frank Gehry para su casa en Santa Mónica 
Esta investigación en definitiva surge del interés por entender los procesos de innovación que tienen lugar en la trasmutación de valor y significado de la materia construida. ${ }^{3}$ Indaga en esa acrobacia que permite a lo ordinario revertir el agotamiento del entusiasmo. Conocemos estos desplazamientos en el arte, y sin embargo aquí nos proponemos evaluarlos desde la arquitectura. Pero no se debe confundir el objetivo de esta tesis con el de estudiar la "artisticidad" de los proyectos seleccionados. No es una investigación sobre estética o composición sino más bien sobre la técnica del proyectar. Es un texto, en su sentido más amplio, que explora las maneras en las que se gestiona lo material como una acción colectiva, en cuanto que es proyectada, recibida e imaginada por una sociedad. Busca también erradicar la noción de que la actuación sobre lo existente es en sí misma una hermana pequeña de la arquitectura o que lo existente es un bastidor sin atributos a la espera de ser vestido. En definitiva esta tesis reivindica que la intervención sobre arquitecturas existentes puede movilizar reflexiones tan profundas, establecer la misma intensidad de debates, ser tan innovadora, provocar con igual energía o, en definitiva, ser tan sexy como la creación ex novo. 


\section{RESUMEN DE CAPÍTULOS}

Esta investigación se organiza en dos bloques. En el primero se estudian por separado los dos campo de estudio involucrados: las agrupaciones heterogéneas y la intervención en arquitecturas ordinarias. El segundo bloque analiza la intersección de dichos campos.

\section{PARTE I}

\section{CAPÍTULO 1. AGRUPACIONES HETEROGÉNEAS: PLASTIC FURNITURE}

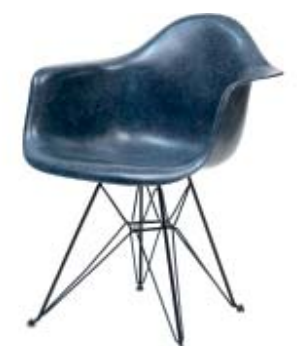

Charles y Ray Eames. DAR Shell Chair con Eiffel Tower Base (años cincuenta).
En el primer capítulo estudiaremos el caso de la Plastic Furniture como ejemplo de agrupación heterogénea. La silla fue ideada por Charles y Ray Eames en 1950 para ofrecer un diseño moderno y de bajo coste para el consumo de masas. Su audacia consistía en proporcionar una colección de asientos y bases intercambiables que podían ser combinados para adaptarse a diferentes funciones y contextos. Los asientos estaban formados por una atractiva cascara de fibra de vidrio con diferentes acabados y colores. Las bases por su parte estaban constituidos por una eclética gama de soportes metálicos o mixtos.

Elegir un objeto aparentemente ajeno a la escala de la arquitectura y de carácter ordinario nos permitirá suspender los prejuicios vinculados a la aproximación de lo edificado y profundizar en nuestro objetivo de entender la herramienta proyectual que lo sustenta. Afirmaremos que la obra de los Eames y, de forma específica, la plastic chair está pensada con las lógicas del montaje, herramienta de origen fotográfico, sobre la que tuvieron una ascendencia importante dos profesores emigrados de la Bauhaus, Làszlò Moholy-Nagy y su discípulo Gyorgy Kepes. Ambos publicaron sendos libros que resultarían seminales para el pensamiento y producción de los Eames.

La interpretación de la silla bajo dichas obras teóricas nos llevará a la conclusión de que la plastic chairy por extensión las agrupaciones heterogéneas se manifiestan como un estado de encuentro. La obra se convierte así en una "duración” en la que se confrontan, a modo de conversación, dos mundos diferenciados. Por último, se visita la silla como estado de encuentro en cinco dimensiones: la dimensión formal, la dimensión pública, la dimensión performativa, la dimensión relacional y la dimensión mestiza. 


\section{CAPÍTULO 2. INTERVENCIÓN EN ARQUITECTURAS}

\section{EXISTENTES: RESISTENCIAS E IMAGINARIOS}

Anne Lacaton y Jean-Philippe Vassal, junto con Frédéric Druot, son los autores de Plus, La vivienda colectiva-Territorio de Excepción, una investigación manifiesto en el que se exponen propuestas de acción arquitectónica para revertir la obsolescencia de los conjuntos habitacionales franceses construidos en la segunda mitad del siglo XX. El documento es una demostración de que las razones que se esgrimían para su demolición no se debían tanto a una obsolescencia funcional como a un agotamiento del entusiasmo consecuencia de un urbanismo segregador y de mínimos.

Para entender los posicionamientos a lo largo de la historia con respecto a lo construido, se realizará un breve repaso de las razones de la preservación, primero, por las relativas a la significación y después por las de base cuantitativa. La aportación de Plus a este debate será la de proponer una suspensión del juicio de las interpretaciones culturales e históricas para aproximarse desde una economía cualitativa. Druot, Lacaton y Vassal establecerán una estrategia para renovar el entusiasmo de los edificios a través de la gestión material de lo construido y la incorporación del imaginario de las Case Study Houses de California. La torre de Bois-le-Prêtre en Paris será la manifestación construida que nos permitirá ver los saltos entre las ideas de partida y el resultado final.

Dicha obra será evaluada bajo la teoría de las Shearing Layers of Change de Steward Brand. En ella Brand propone entender los edificios como una estratificación de capas con diferentes resistencias al cambio. Este análisis mostrará la forma activa en la que lo material responde a los procesos de mutación en el tiempo.

Como conclusión al capítulo se propone la enunciación de una teoría complementaria a la propuesta por Brand: la teoría de la resistencia a los imaginarios. En ella se enuncia que existe una vinculación entre la resistencia al cambio de los diferentes estratos en un edificio y la capacidad de estos para a asumir imaginarios y conservarse en función de los afectos.
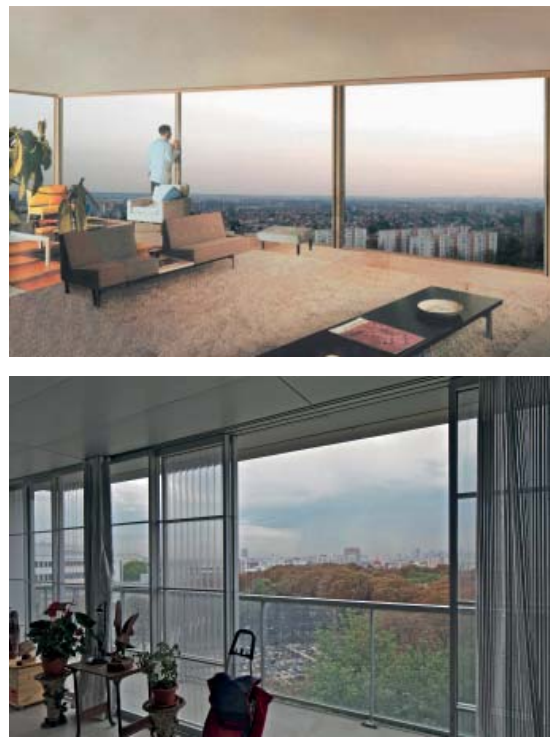

Frédéric Druot Architecture y Anne Lacaton \& Jean Philippe Vassal. Montaje y resultado del edificio residencial Bois Le Prêtre, París (2013).

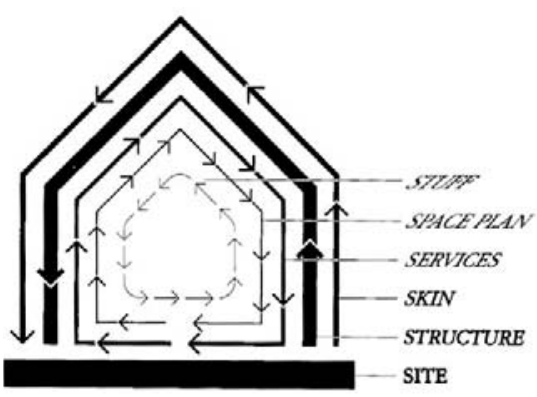

SHEARING LAYERS OF CHANGE. Because of the different rates of change of its components, a building is always tearing itself apart.

Steward Brandt. Shearing layers of change. 


\section{PARTE II}

\section{CAPÍTULO 3. TRANSMUTACIÓN DE VALOR Y SIGNIFICADO}

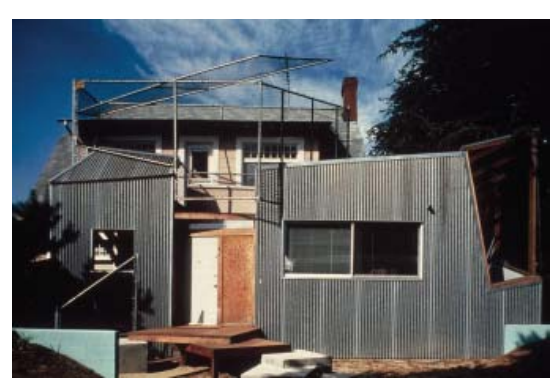

Este capítulo estudiará la intervención sobre las arquitecturas ordinarias mediante la lógica de las agrupaciones heterogéneas. Analizaremos como la incorporación de nuevos imaginarios es capaz de revertir la obsolescencia de lo construido y mostrará que existe una forma de arquitectura cuyo objetivo no es tanto construir el mundo como aprender a habitarlo.

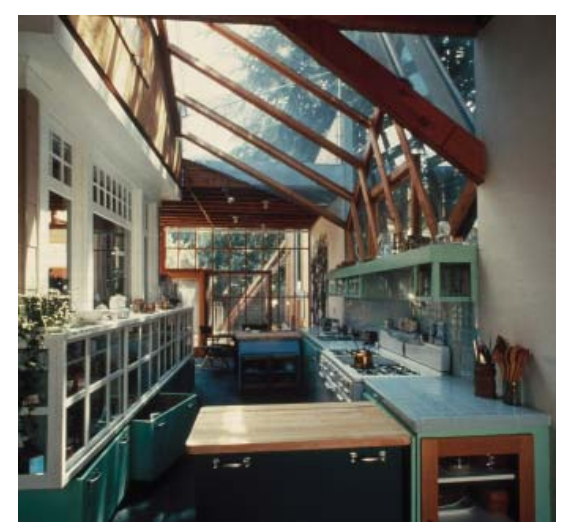

Frank Gehry. Santa Monica.
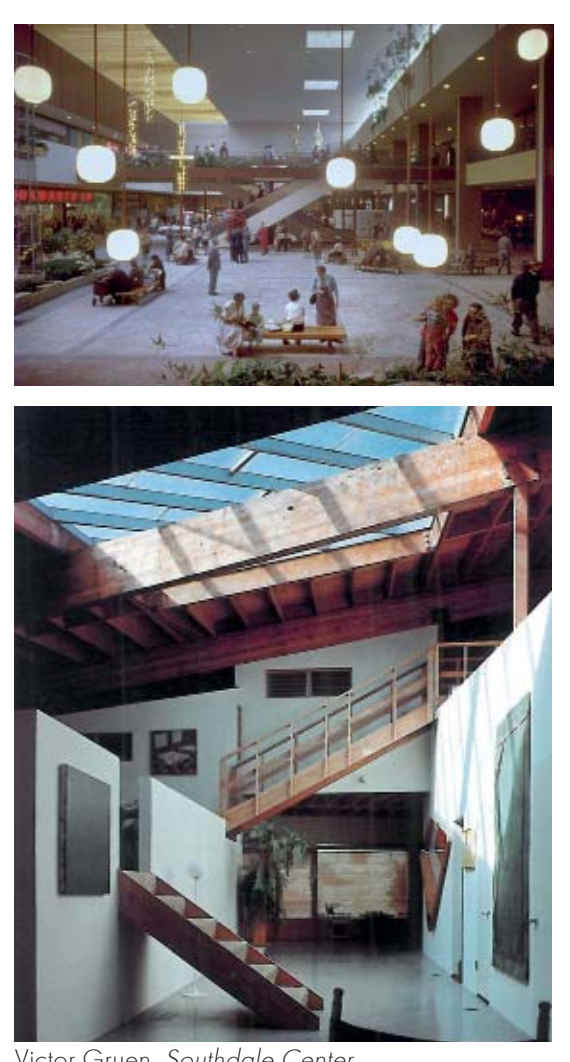

Victor Gruen. Southdale Center. Frank Gehry. Ron Davis House.
$\mathrm{Al}$ igual que en los capítulos precedentes, se explorará este territorio de la mano de una arquitectura concreta. El cicerone elegido esta vez es la casa que Frank O. Gehry transformó para su familia en 1975 en la ciudad de Santa Mónica, California. El proyecto consiste en la transformación de un anónimo bungalow de estilo holandés de los años veinte mediante la adición de una segunda casa: una destartalada acumulación de materiales baratos en posición inestable. El resultado catapultó el proyecto a una nueva dimensión mediática y lo convirtió en un objeto de culto, excitante y polémico, la última casa manifiesto que ha dado la arquitectura doméstica californiana.

Para ser fieles a la dualidad de la casa y ser capaces de identificarla simultáneamente como un todo y una multiplicad se ha optado por analizar y definir la casa por partes. Para referirnos a la casa que abarca desde 1920 hasta la llegada de la intervención de Gehry hemos utilizado de forma intencionada el nombre genérico y anónimo de "casa-rosa". Para denominar a la casa que surge de la acción del arquitecto californiano se utilizará el habitual "casa-Gehry". Para nombrar el conjunto resultante de ambas se ha recurrido al más explícito "totalidad-casa" o su versión geográfica "casa de Santa Mónica."

El interés último de la investigación por entender los mecanismos a través de los que se produce la innovación en la casa de Santa Mónica ha llevado a rastrear los imaginarios que son desplazados en esa intervención. La tesis sostiene que estos se encuentran en los mecanismos de creación de ficción desplegados en la construcción de los centros comerciales de Southdale y Rochester en los que colaboró Gehry cuando trabajaba con el arquitecto Victor Gruen. 
La última parte del capítulo se dedicará al análisis de la totalidad-casa bajo la doble perspectiva que ha guiado nuestra investigación: las agrupaciones heterogéneas y la intervención sobre las arquitecturas existentes. Para ello, primero se analizará la casa como estado de encuentro y posteriormente se evaluará a través de la teoría de la resistencia a los imaginarios. 


\section{ALGUNOS CONCEPTOS}

Antes de adentrarnos en la investigación se ha considerado necesario realizar una aclaración a conceptos con los que el lector se debe familiarizar para moverse cómodamente por las ideas de este texto. Son apuntes y no explicaciones exhaustivas que, en caso de ser necesarias, pueden obtenerse a través de las fuentes originales. Son cuatro:

-Túneles del Tiempo plantea una forma de interpretar las arquitecturas existentes como instrumentos que operan en el tiempo. Surge como parte de la investigación profesional del autor junto a María Langarita.

-Energías cautivas es una aclaración al concepto de la entropía vinculado a la materia de las arquitecturas existentes. Toma como punto de partida las ideas de Nicholas Georgescu-Roegen.

-Economía cultural describe la teoría de Boris Groys sobre los mecanismos que ponen en relación el mundo de lo profano con los archivos de la cultura.

-Innovación por desplazamiento describe la transmutación de valor y significado que tiene lugar en los ready-made de Marcel Duchamp.

\section{TÚNELES DEL TIEMPO 4}

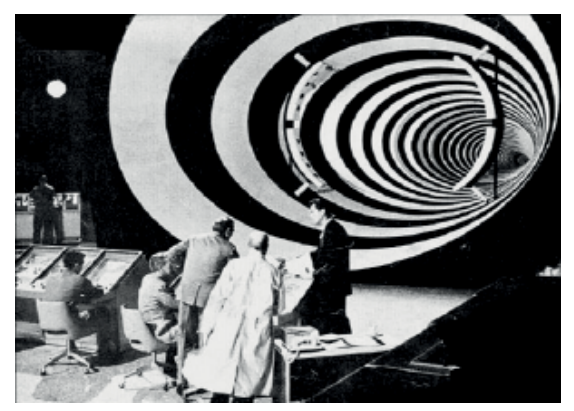

Fotograma de la serie americana de ciencia ficción The Time Tunnel (1966-1967).

4. El presente texto es, con ciertas variaciones, un extracto del artículo "Trabajar con máquinas del Tiempo" publicado originalmente en el monográfico de Langarita y Navarro, 2G 70. Langarita y Navarro, 2015: 163-165
La apertura mágica de un agujero en la pared que atraviesa las convenciones del tiempo y del espacio es un elemento recurrente en muchas películas de ciencia ficción. Aparece por los más diversos motivos y tiene un mantenimiento delicado. En unos casos su presencia pasa desapercibida, en otros transforma los parámetros de la existencia de aquellos que se acercan a él. Es la coartada perfecta para quienes se quieren ir y la excusa para quienes ya no quieren volver; el dilema para quienes deciden arriesgarse y la justificación para quienes se resignan. Lo que salga de ese agujero y lo que de él llegue movilizará las derivas de la trama. El túnel conecta mundos remotos e impulsa erráticos acontecimientos, de ahí la fascinación por las intrigas que genera. Los túneles del tiempo son pura expectativa. 
Curiosamente, cualquier arquitectura comparte esa capacidad, todas son túneles del tiempo. No es una simple metáfora, tampoco una figura poética. La arquitectura se convierte es su posibilidad más pedestre, su prototipo más avanzado, el mejor construido hasta el momento. Las arquitecturas todavía fallan en la teletransportación de los humanos, pero pueden enlazar lo lejano y lo cercano, catapultar lo trivial y, al mismo tiempo, ser el registro de lo que no está aquí. Las arquitecturas son la acumulación de energías en transición, una táctica de preservación y un modo de nemotecnia. Son todo aquello que no puede ser solo explicado por el presente; son el mensaje y la botella. Y, si se activan de la forma adecuada, nos permiten acceder a lo remoto para establecer las relaciones de connivencia y tangencia de nuestro tiempo con los tiempos que fueron y los que están por venir.

En realidad esas arquitecturas están en estado de latencia, desplazándose junto a nosotros, en otras escalas de tiempo, sumadas a ritmos estelares y geológicos o a fugaces y efímeros. Necesitan un desencadenante, un acontecimiento que las active y las ponga en funcionamiento. Sin embargo, no cabe esperar de esa actuación una visión panorámica, clara y totalizadora: un edificio, un lugar o un escenario son campos de operación esquivos y problemáticos. No son un libro; no empiezan ni acaban con la secuencia cerrada de una narración. Son un territorio de contradicción donde se deshacen las certezas y se muestra la multiplicidad. La acumulación de orígenes diversos no solo se hace visible en la variedad de lo material o en su datación histórica, sino también en la superposición de lo inmaterial, en la constatación de que se trata de una amalgama de conocimientos técnicos, relaciones asentadas o rituales sociales, con amplificaciones y derivas que van más allá de sus límites. Evidencian la huella de una cultura latente que puede intuirse o imaginarse, una memoria que ensamblamos sin necesidad de coherencias y que, en arquitectura, se intuye en aspectos tan diversos como la manufactura de los detalles constructivos, las especies vegetales que la colonizan o los restos de una actividad ya extinguida. El objetivo de su conocimiento no es llegar a una síntesis o un resumen, sino, al contrario, establecer aperturas y relaciones.

La arquitectura no solo abre y custodia el acceso a "lo otro remoto", sino que también tiene la propiedad de transportar lo inesperado, como el coche 
de Regreso al futuro ${ }^{5}$ (1985). En la película, los protagonistas se desplazan por el calendario al volante de un DeLorean DMC-12. Lo atolondrado del argumento surge del desplazamiento extemporal de acciones y objetos que casi siempre provienen de lo accesorio, y que, fuera de lugar y ajenos a su contexto, anudan, desestabilizan y alimentan la trama. La acción de lanzar algo al futuro sin un objetivo claro construye un nuevo territorio para lo desconcertante y lo incierto, e irónicamente es la dispersión incontrolada de lo anecdótico lo que da sentido a ese mundo. Son los objetos "proyectados", en su doble acepción de diseñados y lanzados, los que al entrar en el devenir de los acontecimientos empiezan a desarrollar sus propias jugadas.

Por la misma razón, las ideas asumidas sobre la creación entran en un territorio de arenas movedizas cuando trabajamos sobre arquitecturas existentes. No puede ser de otro modo. Es imposible entender el proyectar como un acto solitario. Los proyectos constituyen una cadena de actuaciones, unas veces anónimas y otras conocidas, donde se evidencia una autoría desfigurada. El resultado no puede ser más prometedor, obliga a reducir en nosotros lo mecánico, destruir cualquier tipo de acuerdo a priori para encontrar fugas en las que volver a ensanchar el campo de juego. Saber que no seremos los primeros ni los últimos en intervenir proporciona cierta cualidad liberadora a la producción de la arquitectura. En definitiva, todo eso consiste en estar del lado de lo vivo, de lo que está en movimiento.

5. Back to the Future, titulada Regreso al Futuro en España, es una película de ciencia ficción y comedia de 1985 dirigida y escrita por Robert Zemeckis. La trama relata las aventuras de Marty McFly, un adolescente que es enviado accidentalmente de vuelta en el tiempo de 1985, su época, a 1955.

6. Georgescu-Roegen, 1971

\section{ENERGIAS CAUTIVAS}

La segunda ley de la termodinámica dictamina que la transformación de la energía es única e irreversible, pasando de "energía disponible o aprovechable" a "energía no disponible" hasta desaparecer. Según reconoce GeorgescuRoegen ${ }^{6}$ la ley de la entropía es la más económica de todas las leyes naturales puesto que su enunciado se intersecta con el objetivo fundamental de la economía: la gestión de los recursos escasos. En un mundo sin entropía, no habría ni escasez de energía ni de materiales, continuaríamos usando el mismo trozo de carbón una y otra vez y ni las máquinas ni los organismos vivos se desgastarían. La entropía nos dice que nunca se podrá volver al mismo punto de equilibrio, que no hay posibilidad de retorno. Esta condición hace que las variables cualitativas y evolutivas, que no pueden considerarse dentro 
del paradigma neoclásico mecanicista y circular, se subrayen y adquieran una vigencia esencial para el trabajo del arquitecto. Encargada de la gestión de lo material del medio ambiente construido, la arquitectura se enfrenta y a su vez se alía con la entropía, con el tiempo.

El éxito que la física se atribuye así misma está vinculado al hecho de que esta ciencia estudia solamente la materia uniforme. Aquello que no está sujeta a variables. Sería más apropiado decir que la física estudia solamente aquellas propiedades de la materia que son constantes, es decir, independientes tanto de la novedad por combinación como del tiempo, condiciones que, por otra parte, se encuentran estrechamente relacionadas. Si la física estudiase todas las posibles novedades por combinación de la materia elemental, incluiría no sólo a la química sino también la biología, la psicología, la sociología, la arquitectura, en una palabra, todo. Estudiaría entonces propiedades que no son independientes del tiempo. ${ }^{7}$

Sin embargo, como ya hemos visto, si de algo se encarga la arquitectura es del tiempo". "Viaje al interior del tiempo" la renombró Luis Moreno Mansilla. Un viaje de potencialidades en degradación constante. Un viaje que consume la materia y la memoria -que también viaja, aunque adherida con mayor levedad-. Toda construcción contiene unas energías cautivas, un material corpóreo o invisible que la humanidad se afana por mantener, destruir o simplemente dejar estar. Viaja en forma de materia, en los modos de lo inorgánico y lo orgánico, pero también como conocimientos y tecnologías no corpóreas que se adivinan como fantasmas. Advertidos de la irreversibilidad del proceso, de la inexorable degradación, del incremento de la entropía, las sociedades tratan de forma muy diversa ese material y le atribuyen poderes muy diversos. El fundamento de la irreversibilidad es "psicológico», pues se deriva del hecho de que «tenemos una memoria del pasado y podemos poseer así conocimiento de lo que sucedió en un tiempo anterior, pero no de lo que sucederá en un momento posterior». ${ }^{10}$ Ese aspecto obliga a pensar que es inviable un mundo ajeno al observador e incluso a depender obligadamente de la conciencia humana o de una uniformidad de la conciencia humana.

Al enfrentarnos, como sociedad, a lo existente, surgen unos vínculos complejos de valor y también se activan unos mecanismos de reacción. A veces es tratado solo como un residuo, otras como un recuerdo y las menos
7. Es cierto que la física no ha sido capaz de mantener totalmente al tiempo fuera de su campo de estudio: la termodinámica y la astrofísica se ocupan de los cambios de la materia en el tiempo.

8. "Tiempo: el gran misterio. A pesar de ser una palabra relativamente corta, Tiempo denota una complejidad extraordinaria......el Tiempo no puede reconstruirse a partir del continuo aritmético de sus instantes, pero este rasgo por sí solo no basta para diferenciar el Tiempo del Espacio. La estructura del Tiempo consiste no en duraciones colindantes sino solapadas (o presentes engañosos, como se le llama con frecuencia). Además se solapan en una estructura dialéctica, no aritmomórfica. El rasgo peculiarmente único del Tiempo es su fugaz carácter combinado con su omnipresencia. El Tiempo fluye, pero está siempre presente. Esta es la razón por la que el problema del Tiempo ha torturado las mentes de todos los grandes filósofos mucho más que su correlativo, el Espacio." En Georgescu-Roegen, 1996: 184

9. Mansilla, 2002

10. Georgescu-Roegen, 1996: 188 
como un ente singular, capaz de concentrar toda una cultura. Aunque trataremos el tema de la preservación más adelante, nos interesa entender aquí que existe una capacidad humana para desviar la tendencia irrevocable de la materia a su desaparición. Esa herramienta, tan mágica como la máquina del tiempo, es la de la significación. Un proceso a través del cual otorgamos a la materia unos nuevos poderes, los del arte, aquellos que les permiten permanecer como muestra de lo que somos o hemos sido en los archivos de la cultura. A esa labor lo llamamos innovación y es el objetivo último de esta investigación.

\section{ECONOMÍA CULTURAL}

Boris Groys traza una lectura precisa y profundamente reveladora de los mecanismos que rigen la innovación. Para ello hay que adentrarse un poco más en su pensamiento y entender los criterios y mecanismos bajo los que la cultura considera que algo de la esfera de lo profano debe ocupar un lugar en sus archivos:

"La "economía cultural" es el intercambio que se produce entre el archivo de los valores culturales y el espacio profano exterior a este archivo. En el archivo se coleccionan y custodian cosas que son importantes, relevantes o valiosas para una determinada cultura; todas las demás cosas sin importancia, irrelevantes o sin valor, quedan fuera del archivo en el espacio profano. Sin embargo, los archivos culturales cambian constantemente: una parte del espacio profano se incorpora a ellos, mientras que otra parte de las existencia del archivo se desecha como algo que ha dejado de ser relevante"11

Y prosigue:

"El archivo es una máquina de producción de recuerdos, una máquina que fábrica historia a partir del material de la realidad que no está recopilado. De manera que el archivo cultural se encuentra en una contradicción interna, producida por su propia dinámica. Por una parte el archivo tiene vocación de exhaustividad: debe reunir y representar todo aquello que se encuentra fuera de él. Pero, por otra, 
las cosas del interior del archivo tienen un destino completamente distinto a la del exterior a él: las cosas del archivo son consideradas valiosas y dignas de ser protegidas, mientras que se acepta sin más la decadencia, la mortalidad y la brevedad de las cosas profanas." ${ }^{12}$

Esta forma de entender la innovación desarma muchos de los a prioris con los que habitualmente nos acercamos a su funcionamiento. Lo nuevo no sería un descubrimiento desde la interioridad, un desvelamiento de lo oculto o la creación desde la no-materia a la materia. Lo nuevo por el contrario sería accesible y visible desde el principio. Y ha de ser así porque lo nuevo, solo lo puede ser en relación a otros. El valor de una obra de la cultura se determina en relación con otras obras, no mediante su confrontación con la realidad exterior a la cultura, o por su verdad o por su sentido. La innovación no consiste en que comparezca algo que estaba escondido, sino en trasmutar el valor de algo visto y conocido desde siempre. Groys apunta en este sentido:

"La transmutación de los valores es la forma general de la innovación: en ese acontecimiento, lo verdadero y lo distinguido, que tiene vigencia como valioso, resulta devaluado, y se revaloriza lo que antes se consideraba carente de valor, profano, extraño, primitivo o vulgar. Como transmutación de valores, la innovación es, pues, un proceso económico. Por eso, la exigencia de lo nuevo pertenece al ámbito de las obligaciones económicas que determinan la entera vida de las sociedades. La economía consiste en el tráfico con los valores dentro de una determinada jerarquía de valores." ${ }^{13}$

Como puntualización debería quedar claro que el sentido expuesto por Groys para el término de economía es ajeno al sistema económico en términos monetarios y la palabra valor no guarda relación ninguna con la esfera de los mercados. Tampoco la cultura es la representación de los procesos económicos exteriores a ella, por el contrario lo que pretende mostrar esta teoría es que la lógica del desarrollo cultural es igual a la lógica de la transmutación de valores. La cultura es siempre una jerarquía de valores. Cada acción cultural confirma o modifica esa jerarquía, y por lo tanto redefine la relevancia o irrelevancia de la existencia de los archivos. 
14. Citan como origen de estos procesos una anécdota ocurrida en 1912 con motivo de una visita al Salon de la Locomotion Aérienne en la que Marcel Duchamp hizo la siguiente observación a Constantine Brancusi: "La pintura ha muerto. ¿̇Quién haría algo mejor que esta hélice? Dime, ¿̇podrías hacer esto?" en Foster, 2006: 127

15. Groys, 2005: 117

\section{INNOVACIÓN POR DESPLAZAMIENTO}

La categoría del ready-made supuso un cambio radical en el arte y en el concepto de innovación. El arte de la modernidad, desde el Renacimiento, rompió con la tradición anterior y se alejó de la imagen fiel de la realidad exterior en su búsqueda de la representación verdadera. En las vanguardias el arte fue interpretado por muchos como una imagen de la realidad interior, oculta, como una búsqueda de la verdad y de la autenticidad de la que había que buscar su origen. Estas visiones se vieron sacudidas y puestas en crisis cuando Marcel Duchamp utilizó la cita directa de la realidad exterior a la cultura. El ready-made, esa estrategia de "combinación del azar y la elección, de lo arbitrario y lo dado" ${ }^{14}$, fue el artífice de esta acrobacia intelectual. La primera ocasión en la que Duchamp utilizó esta estrategia, aunque todavía sin recibir ese nombre, fue una rueda de bicicleta invertida sobre el asiento de un taburete. Con esta empezó una serie de obras en las que aplicó una estrategia similar, un desplazamiento que constituía un cambio de valor cultural del objeto elegido. Estas obras de Duchamp contienen siempre dos estratos. Uno de ellos apunta a tradición de la cultura valorizada; el otro al espacio de lo profano, de lo que carece valor, que se asocia a la "realidad en sí". El resultado es una co-existencia de mundos, en la que la presencia de ambos dos estratos en una obra de arte genera una tensión, que es la que produce el valor de la obra. ${ }^{15} \mathrm{La}$ innovación de los Ready-made se convierte en una acción de desplazamiento. Un desplazamiento que cuenta con la presencia permanente del inicio y el final. Por ello se convierte en un conector de dimensiones distantes, y por ello la arquitectura que, como ya hemos indicado, y veremos puede tener la propiedad de la simultaneidad, es capaz de participar de los mismos mecanismos. 

PARTE I 



\section{CAPÍtULO 1.}

AGRUPACIONES

HETEROGÉNEAS:

LA PLASTIC FURNITURE

DE CHARLES Y RAY EAMES 

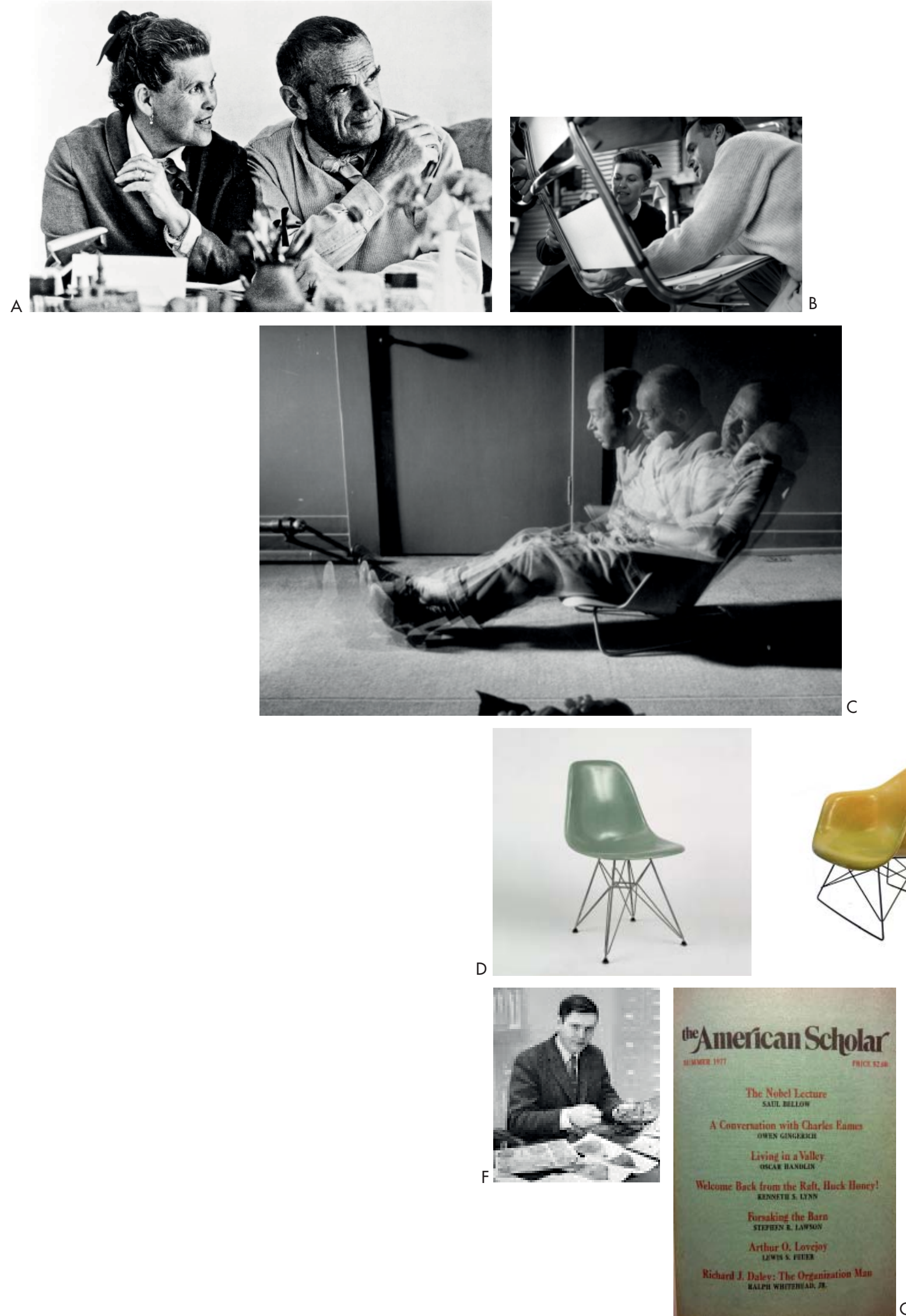
En el poema aparentemente más etéreo late en sordina una visión del mundo.

Édouard Glissant

Las sillas siempre han sido las precursoras de un cambio en el mundo del diseño.

Alison y Peter Smithson

\subsection{UNA SILLA, UNA ARQUITECTURA}

A. Ray y Charles Eames en la Aspen Design conference, 1976

B. Ray y Charles Eames con un prototipo de las Aluminium Chairs, 1957.

C. Exposición múltiple del director de cine Billy Wilder, sentado en la silla diseñada por Ray y Charles Eames.

D. Ray y Charles Eames. Silla DSR, Dining or desk height Sideshell Wire (Rod) base, (1954). Producida por Herman Miller.

E. Ray y Charles Eames. Silla LAR, Low Armchair, (1957). Producida por Herman Miller.

F. Owen Gingerich, profesor emérito de Astronomía e Historia de la Ciencia y de la Tecnología en Harvard University.

G. Portada de American Scholar. Vol. 46, 1977.

16. Lo habitual era que las entrevistas, textos y conferencias fueran firmadas exclusivamente por Charles Eames. Es por eso que se han singularizado en él las citas si así lo indicaban las fuentes utilizadas. En el resto de las ocasiones se ha utilizado el plural Eames para referirnos a la pareja de Ray y Charles Eames, y según el contexto también se podría hacer extensivo al equipo de la Eames Office.

17. Gingerich, 1977

18. Charles y Ray Eames se mudaron a California en 1940.

19. Por aquellos años los Eames se dedicaban casi exclusivamente a realizar películas, diseño de exposiciones e investigaciones sobre docencia y comunicación.
Una silla es una arquitectura. Así lo creía Charles Eames ${ }^{16}$ y así se lo trasmitió a Owen Gingerich, profesor de astronomía e historia de la ciencia en la Universidad de Harvard, en una entrevista en 1977 publicada en el volumen 46 de American Scholar. ${ }^{17}$ Habían pasado treinta y ocho años desde que Ray Kaiser y él hubieran decidido abrir su oficina y empezar una nueva vida en la ciudad de Los Ángeles ${ }^{18}$. No parece que la afirmación sobre la silla fuera casual, ni siquiera improvisada. Era sin duda una reflexión meditada, el pensamiento de toda una vida. En el momento de la conversación hacía casi una década que los Eames no diseñaban una nueva pieza de mobiliario. Las últimas que habían producido eran las Aluminium Chairs en $1968^{19}$. Sin embargo, la primera pregunta de la conversación pasaba por alto ese dato. Para el entrevistador -como para muchos otros- los Eames seguían estando, a pesar del tiempo transcurrido, encarnados en su mobiliario:

"Owen Gingerich: Most people, I believe, think of you in terms of chairs. I remember so well how, when we were starting on the Copernicus show, we arrived at the Arlanda Airport in Sweden and you looked around and said, "These are all my chairs." 

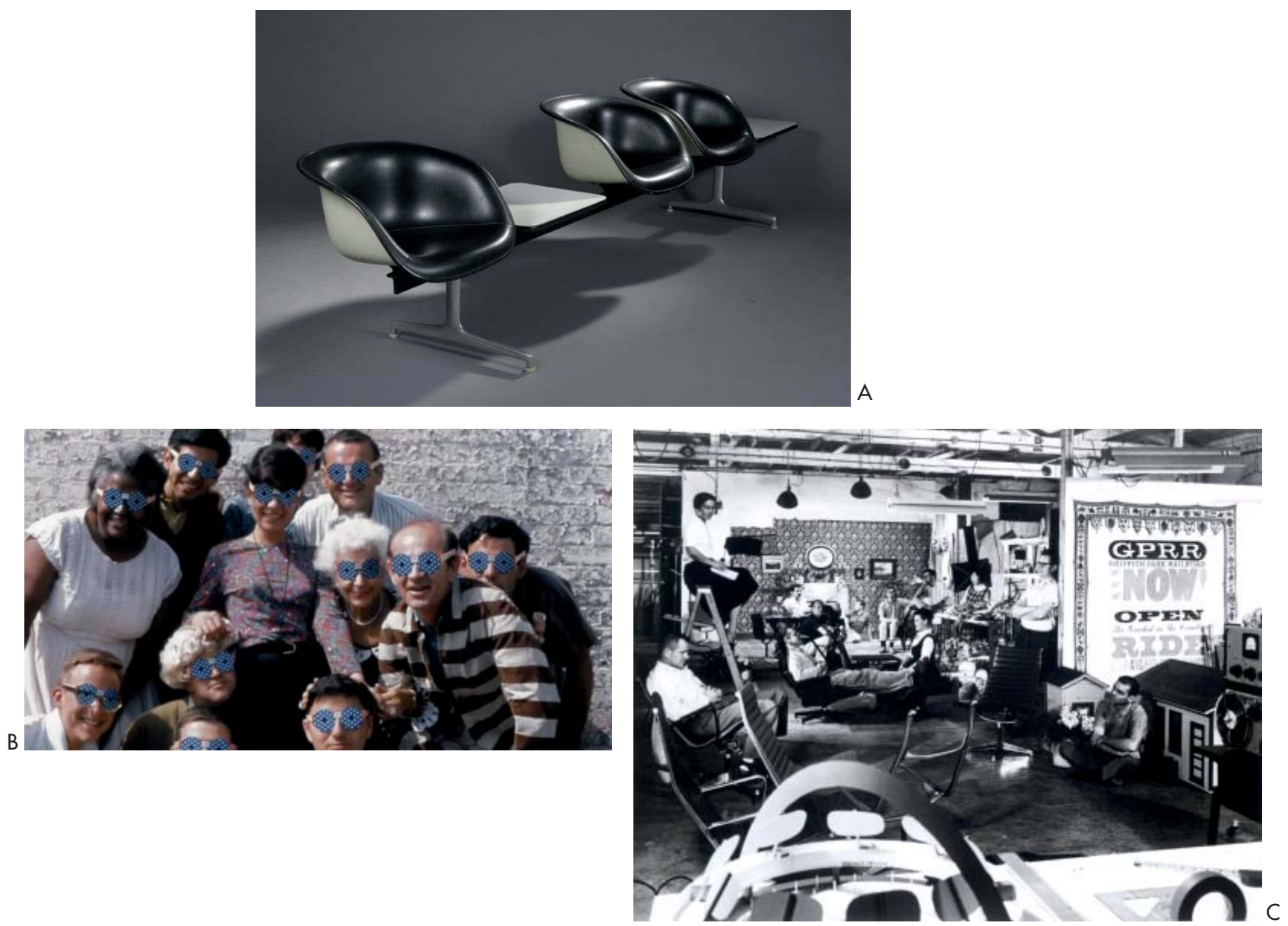
A. Charles y Ray Eames. Tandem Shell Seating Unit (1962). Fabricada para su uso en aeropuertos. Producida por Herman Miller.

B. Los trabajadores de la Eames Office celebrando July 4th, 1965.

C. La Eames Office con Charles y Ray Eames y el personal, incluyendo a John Neuhart y Don Albinson en primer plano. Posiblemente en el momento de la realización de la película $A n$ Introduction to Feedback (1960).
Charles Eames: I probably said, 'These are all our chairs.'

Gingerich: Never mind.

Eames: But it's unlike me to say 'my chairs.'

Gingerich: But nevertheless they were from your designs." ${ }^{20}$

Eran sus sillas y estaban en un aeropuerto sueco. Se habían convertido en un diseño cosmopolita y global. De hecho a Eames, como reconoció en la entrevista, le resultó decepcionante que en Suecia tuvieran sillas americanas, aunque fueran las suyas, en lugar de promover una experiencia local, exótica para los visitantes. ${ }^{21}$ Imaginamos que ese mismo razonamiento llevó al entrevistador a preguntar por el tema del diseño y a cuestionar por qué, siendo las sillas su producto más popular y sin haber construido prácticamente ningún edificio, todavía se autodenominaba arquitecto:

"Gingerich: Most people would call you a designer, but I know you prefer to think of yourself as an architect. How do the chairs fit in to that?

Eames: I think I've mentioned to you that we consider this all as architecture: the chairs are architecture, the films they have structure just as the front page of a newspaper has structure. The chairs are literally like architecture in miniature. For an architect who has difficulty controlling a building because of the contractor and the various forces brought to bear on anything that costs that much money, a chair is almost handleable on a human scale, and so you find great architects turning to chairs: Frank Lloyd Wright, Mies van der Rohe, Le Corbusier, Aalto, Eero Saarinen- any number of them doing it, because this is architecture you can get your hands on."22
Para los Eames todo era arquitectura. La definición no provenía del objeto, no era una cuestión de escala ni era un problema de tamaño, sino de la actitud, de la forma en la que uno se aproximaba al diseño. Otros, cuando habían diseñado sillas no habían dejado de ser arquitectos y por eso ellos, sin 


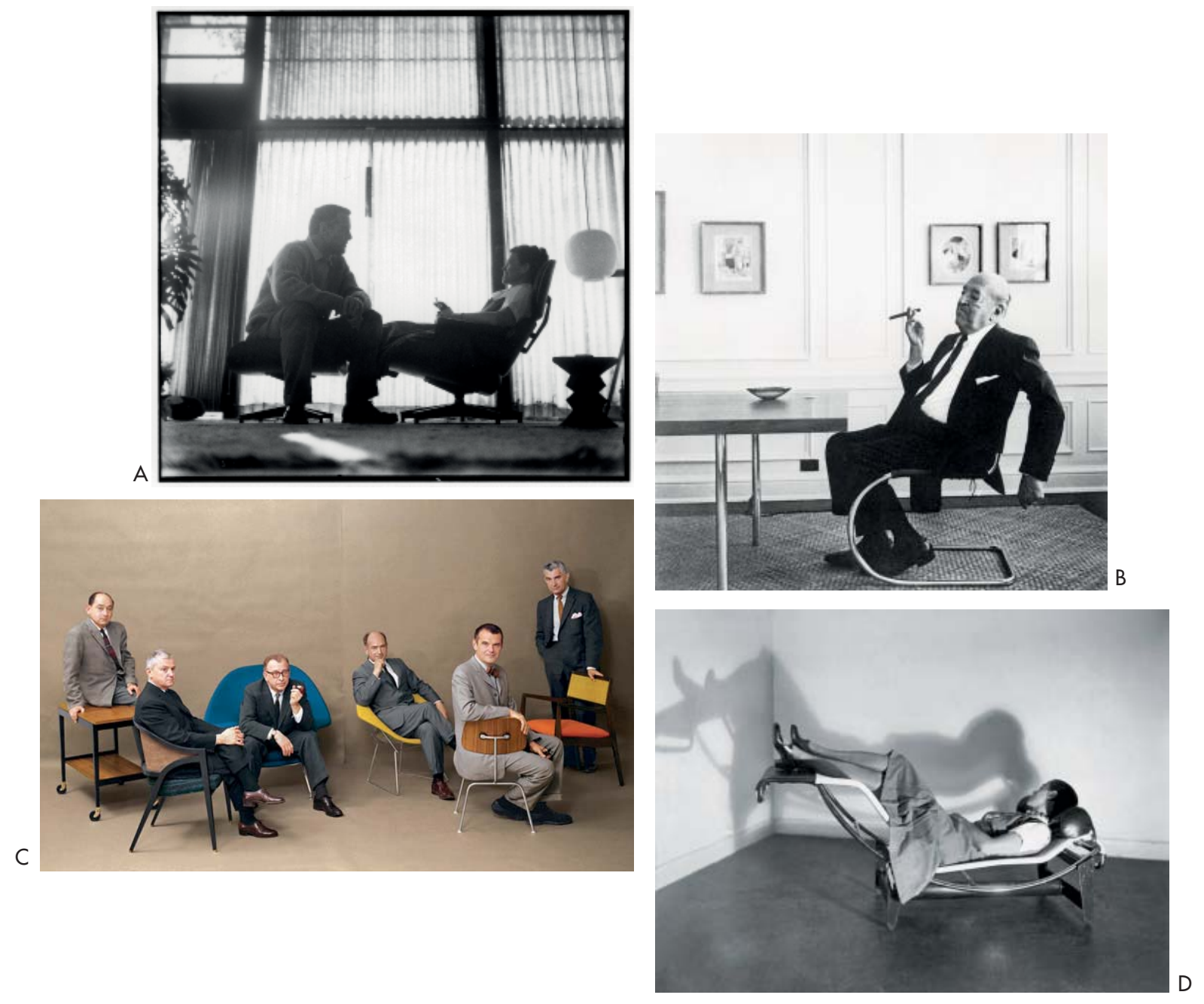


A. Ray y Charles Eames en la Vitra Lounge Chair. B. George Nelson, Edward Wormley, Eero Saarinen, Harry Bertoia, Charles Eames y Jens Risom con sus diseños para el número de Julio de 1961 de la revista Playboy.

C. Mies van Der Rohe en la Silla MR 10 (1927), diseñada junto con Lilly Reich.

D. Charlotte Perriand en la Chaise Longue B306, 1928

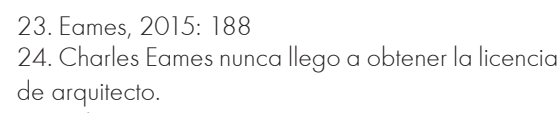

haber construido apenas edificios, seguían siendo arquitectos. En definitiva, las sillas podían ser pequeñas, podían ser corrientes o podían ser genéricas pero sin duda eran arquitectura.

Charles Eames dedicó un texto exclusivamente a este tema con el elocuente título de Architecture in Miniature ${ }^{23}$. Afirmaba que no era casual el hecho de que numerosos arquitectos -y citaba a Mies van der Rohe, Alvar Aalto, Marcel Breuer, Le Corbusier, Antonin Raymond, Eero Saarinen, George Nelson, Alexander Girard y Florence Knoll- se hubieran acercado al mobiliario de forma intencionada. Lo entendía por su proximidad con la escala humana y por la capacidad de condensar conceptos y corazonadas. Los arquitectos utilizaban el diseño de mobiliario como un campo de pruebas donde experimentar los límites de las ideas, con la poderosa ventaja de que aquello se comportaba como un laboratorio esterilizado a las incomodas contingencias de la edificación. Libertad y densidad eran lo que ofrecía el confortable espacio de los enseres del hogar.

Otros insinuaron que lo de seguir llamándose arquitectos era una forma de apropiarse del respeto social que con la denominación de diseñadores nunca hubieran alcanzado. ${ }^{24}$ No sabemos si fue por mantener su orgullo o por pura convicción pero parece que ese tipo de comentarios fue lo que les animó durante toda su carrera a hacer una pedagogía continua para desmontar prejuicios y deshacer las jerarquías que categorizaban lo que era y no era arquitectura. Lo que ocultaba su insistencia por llamarse arquitectos era una concepción más profunda y meditada de las derivas que tenía el acto de diseñar. Una concepción que implicaba pensar no solo en la forma sino también en la técnica y el tiempo. El objetivo detrás de todo, era hacer entender que la arquitectura como el diseño, era un verbo, no un sujeto; una acción, no un objeto.

Charles Eames se defendía:

"It is not that I'm embarrassed about 'designer' so much as the degree to which I prefer the word 'architect' and what implies. It implies structure, a kind of analysis, as well as a kind of tradition behind it." 25 

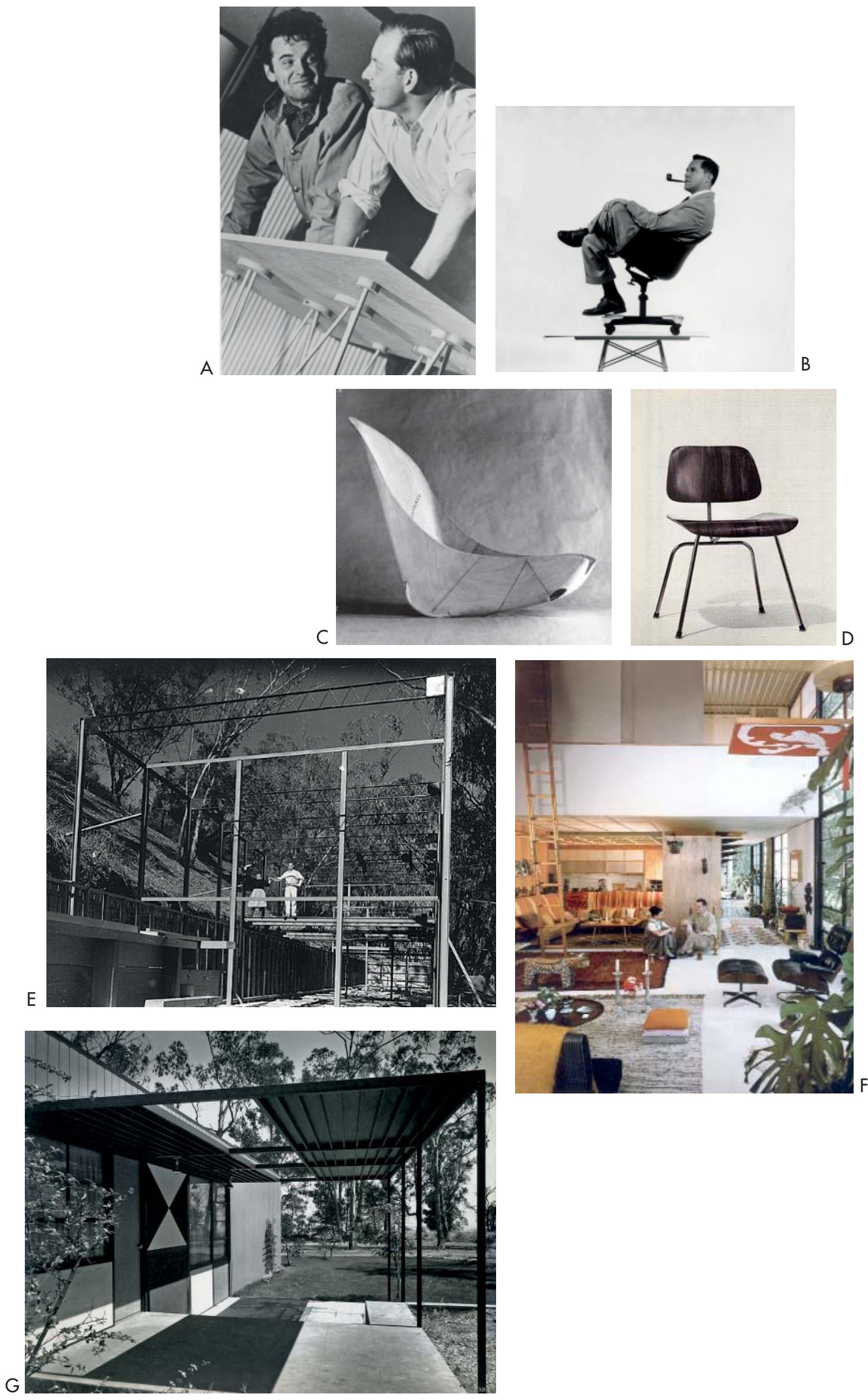
A. Eero Saarinen y Charles Eames probando una estructura de tracción ligera para para

la exposición en Cranbrook Academy of Art \&Architecture, 1939

B. Charles Eames sobre silla y mesa.

C. Charles y Ray Eames. Plyformed (1943). Prototipo para asiento de piloto realizado mediante madera laminada estampada.

D. Charles y Ray Eames. Silla DCM (1946) Realizada mediante contrachapado y tubo de acero.

E. Charles and Ray Eames en la estructura de la Eames House, 1949

F. Charles and Ray Eames en su casa en Pacific Palisades, 1949

G. Charles Eames y Eerro Saarinen. Case StudyHouse \#9 (1949). Foto de Julius Shulman.
Con motivo de una conferencia volvía a insistir:

"So, broadly, the function of design would be to apply the technical advantages developed by man to the evolutionary problems of man. And the aesthetics of design will be to the degree which the solution of these problems adds to the richness of man's life, whether it's applied on a very large scale or a very small scale...."26

La conferencia llevaba el elocuente título de Design Today y fue impartida en la University of Washington Arboretum de Seattle en Octubre de 1950. Por aquellas fechas en los tableros de su oficina se simultaneaban las escalas. Hacía pocos meses que Charles y Ray Eames habían terminado su casa en Pacific Palisades y ultimaban las obras de la Case Study House 9. También habían empezado a producir, después del éxito de las plywood chairs, una nueva familia de sillas para la empresa de mobiliario Herman Miller, las plastic chairs. Habían sido ideadas como un sistema que funcionaba por la combinación de dos partes: un asiento-cascara de doble curvatura realizado mediante fibra de vidrio susceptible de ser producida en diferentes acabados y una base que aportaba diversas soluciones para uso doméstico y comercial.

Tanto las casas como las sillas compartían una misma actitud y partían de las mismas inquietudes: La posibilidad de utilizar la tecnología avanzada de la industria, la producción en serie, la apuesta por una fabricación económica, la amplificación de las experiencias sensibles o la activación de los sentidos a través del constraste entre las geometrías o el color. Ambas son ejemplos tan fascinantes que han recibido merecida atención. Sin embargo se han escrito muchas páginas de la casa como arquitectura y bien pocas de la silla como arquitectura. Nos proponemos equilibrar la balanza con algunas páginas a su favor. 

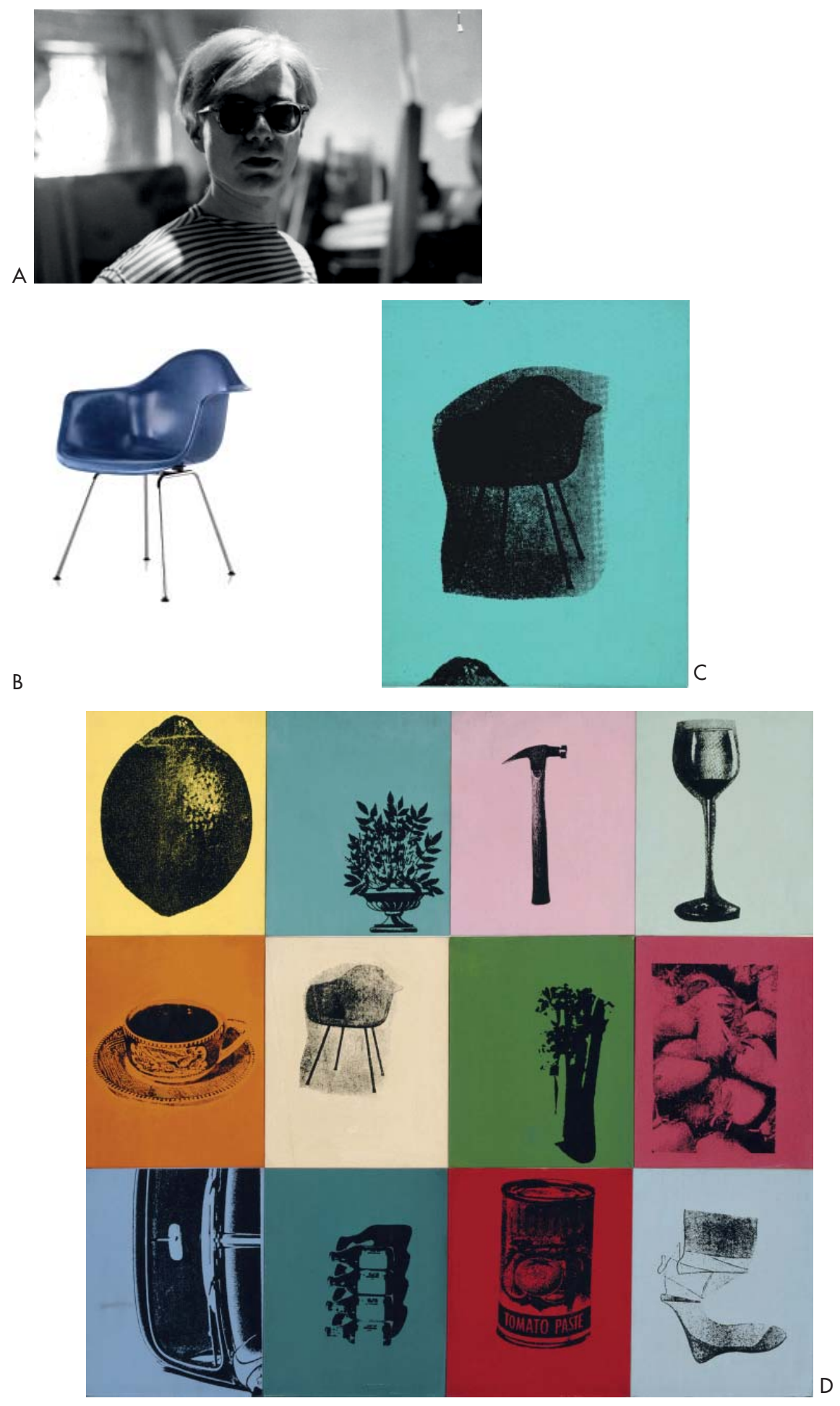


\subsection{UNA SILLA ORDINARIA}

A. Andy Warhol, 1963.

B. Charles y Ray Eames. Shell Chair (1961).

C. Andy Warhol. Serigrafía de la Armchair en la serie Container Corporation of America Seires (1963).

D. Andy Warhol. Serigrafía sobre lienzo de la serie completa de Container Corporation of AmericaSeires (1963).

27. A lo largo del texto se utilizará el término genérico América para referirse a Estados Unidos. Aunque el autor es consciente de la inexactitud, ha decidido utilizar esa denominación por considerarla más próxima al espíritu de los textos y hechos que se comentan.

28. La producción de la silla por parte Herman Miller se interrumpió en 1989 y se reanudó por Vitra en 2004.

29. "¿Promete su embalaje preservar, defender, guardar, proteger, cobijar, alojar, cuidar, presentar y vender su producto?"
La Plastic Furniture de Charles y Ray Eames fue un éxito. Hoy lo sigue siendo. Aunque en su genética ya estaba ser producida en masa es difícil saber que la convirtió en un producto con tanta aceptación. Fue pensada para proveer de un mobiliario moderno a una América ${ }^{27}$ recién salida de la guerra y ha pervivido, incluso resucitado ${ }^{28}$, hasta llegar a nuestros días. Son aclamadas por especialistas y profanos. No fue el único de sus diseños que lo consiguió pero, de todos los que concibieron, es probablemente el que más lejos ha llegado. No es raro encontrarlas, originales y copias, en sus múltiples combinaciones. Ocupa páginas de prestigio en igual proporción que en las revistas de decoración. Ya sea por su belleza, precio o por la facilidad para ser reproducida, se ha convertido en un estándar de nuestra cultura. Un éxito Pop.

Esta afirmación no es casual ni arbitraria. De entre muchos objetos posibles, un audaz observador de la cultura popular como es Andy Warhol, seleccionó la silla para formar parte de su imaginario Pop. La Armchair, la versión con brazos de la plastic furniture, apareció en la serie Corporate Trade $A d$ rodeada de otros once objetos cotidianos: un limón, una planta, un martillo, un vaso de vino, una taza de café, un manojo de apio, algunas fresas, el parabrisas de un coche, unos botes de pastillas, una lata de tomate y una media de nylon.

La obra está fechada en 1963, al principio de su carrera, y fue un encargo de la Container Corporation of America, el líder en fabricación de envases de Estados Unidos, como parte de un cambio en la estrategia de publicidad de la compañía. Warhol propuso para el anuncio una aproximación diferente a la previsible tendencia por singularizar y destacar a la corporación por encima de todo. Lejos de centrarse en la marca, la obra ayuda a distanciar a la empresa de la descarada y engañosa imaginería de la venta de productos. Lo que se muestra es una colección de objetos de consumo triviales sin una aparente voluntad comercial. El mensaje que los acompañaba encajaba con la matriz de imágenes: "Does your package promise to preserve, defend, guard, shield, shelter, house, care for, present - and sell your product?"'29 La multiplicidad de verbos tenía su eco en la multiplicidad de imágenes. Al mismo tiempo la elección del término product aludía a la impersonalidad de las cosas allí reunidas. No era casual, los objetos elegidos debían ser 

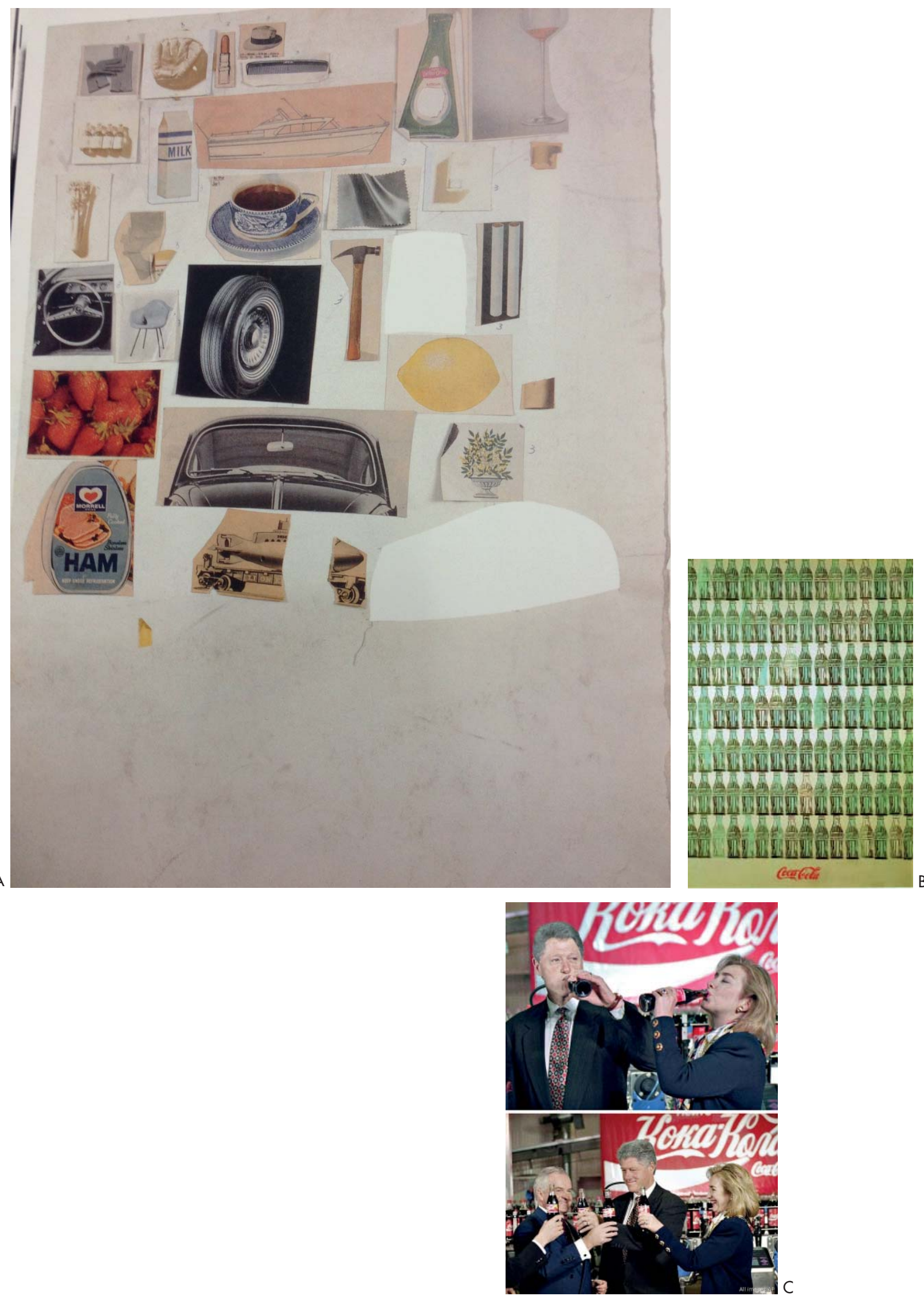
A. Andy Warhol. Collage preparatorio para la serie Container Corporation of AmericaSeires (1963).

B. Andy Warhol. Green Coca-Cola-Bottles (1963).

C. El presidente de los Estados Unidos Bill Clinton y Hillary Rodham Clinton bebiendo Coca-Cola en Moscú, 1995
30. Por aquellas fechas Warhol estaba empezando a trabajar en las famosas series de marcas comerciales. En Noviembre de 1962 inauguró su primera exposición en Nueva York en la galería Stable. Allí incluyó el díptico de Marilyn, 100 latas de sopa, 100 botellas de cola y 100 billetes de dólar.

31. Warhol, 1975: 21 cotidianos y universales. Incluso Warhol evita de forma intencionada que quede representada ninguna marca comercial. Los nombres se enmascaran en borrosas manchas, la marca de la sopa se desdibuja y se rota el parabrisas de un Volkswagen para que no sea identificado a simple vista. Todos son objetos conocidos y al mismo tiempo todos son genéricos.

Esta actitud sin duda contrasta con su obra de aquel periodo y de lo que sería su exitoso futuro artístico. ${ }^{30}$ Quizá como reacción a este encargo, Warhol poco después, empezaría una prolífica cantidad de obras en las que los embalajes recobrarían una singular importancia. En cualquier caso, la voluntad de la obra realizada para la Container Corporation of America era evidente: buscar objetos ordinarios que formaran parte de la memoria colectiva americana. En ese sentido es especialmente esclarecedor el collage preparatorio para la realización del anuncio. En él se ven las imágenes elegidas, todavía sin postproducir, sumadas a otras que no llegaron a aparecer definitivamente en la publicidad. Salvo por la inclusión de un barco y un submarino, que parecen fuera de lugar, el resto fija el territorio del día a día. Cigarrillos y pintalabios; peines y limones; guantes y ruedas. Los productos cotidianos de una América que se adentraba en una espiral de consumo y mercadotecnia para insinuar que todos sus ciudadanos podían participar de un mismo sueño de prosperidad. Un Warhol lúcido y naif lo resumía con ironía en una sentencia que ya se ha hecho mítica:

"Lo bueno de este país es que América empezó la tradición por la cual los consumidores más ricos compran esencialmente las mismas cosas que los pobres. Puedes estar viendo la tele y ver una CocaCola, y puedes saber que el Presidente bebe Coca-Cola, Liz Taylor bebe Coca-Cola, y piénsalo, tú también puedes beber Coca-Cola. Una Coca-Cola es una Coca-Cola y ninguna cantidad de dinero puede brindarte una mejor Coca-Cola que la que está bebiendo el mendigo de la esquina. Todas las Coca-Colas son iguales y todas las Coca-Colas son buenas. Liz Taylor lo sabe, el presidente lo sabe, el mendigo lo sabe y tú lo sabes." ${ }^{31}$

Si una Coca-Cola podía ser igual para todos por qué no lo iba a ser una silla. Hagamos el ejercicio de sustituir la bebida carbonatada por el trabajo de los Eames. La afirmación también podría ser cierta: El presidente se sienta en 

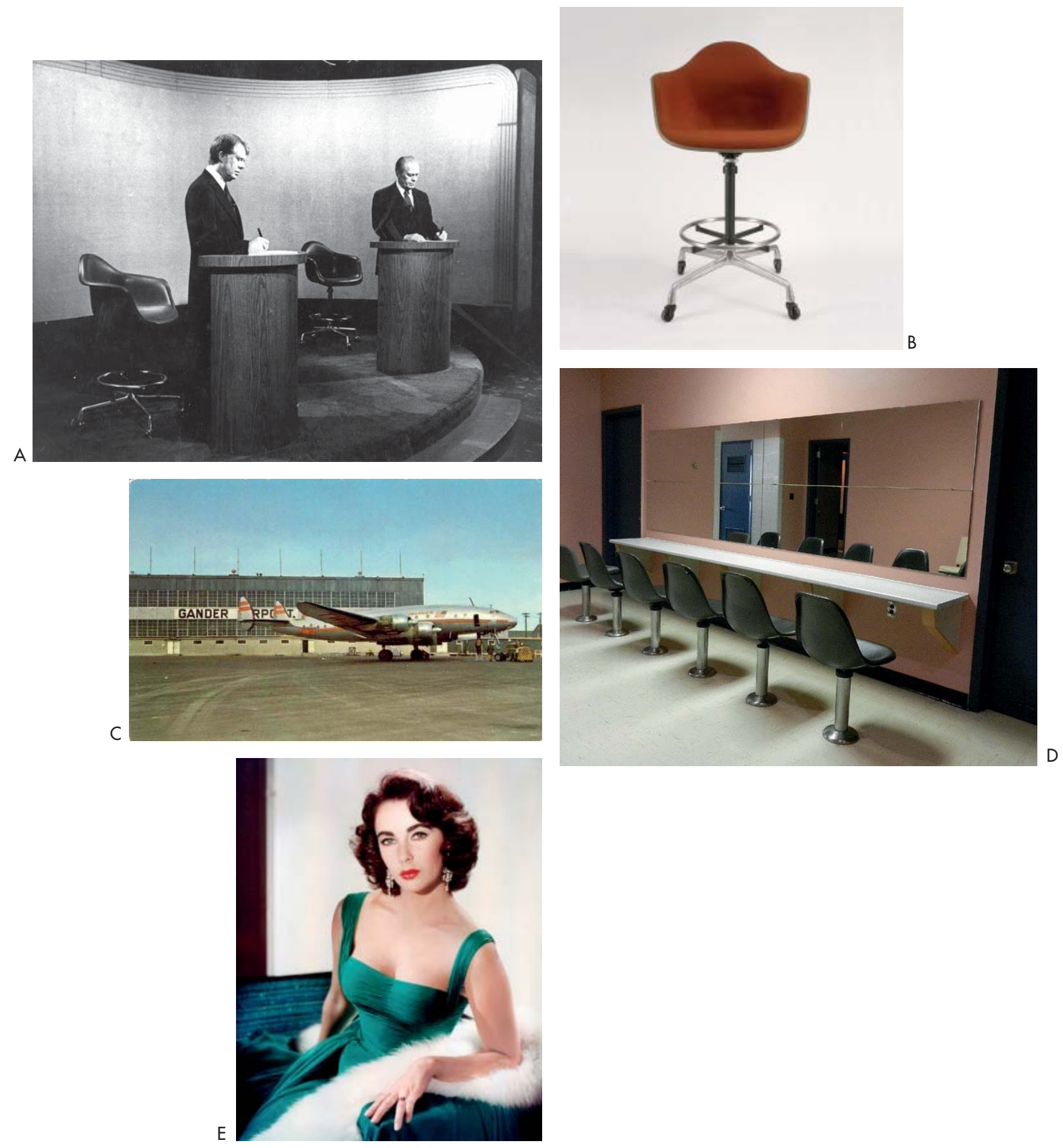
A. Jimmy Carter y Gerald Ford en el debate presidencial con las Eames Chair, 1976.

B. Charles y Ray Eames. Eames EC 118 (1970). Silla similar a la utilizada en el debate de Carter y Ford.

C. Terminal de pasajeros del aeropuerto Gander Canada, años 60

D. Charles y Ray Eames. Sillas del aseo de mujeres del aeropuerto Gander Airport, Canada.

E. Elizabeth Taylor, 1960
32. En el National Museum of American History se puede consultar la puesta en escena del debate y su representación dentro y fuera de la pantalla.

33. Gollner, 2005

34. El concepto de aura de la obra de arte surge de las reflexiones de Walter Benjamin expuestas en su texto paradigmático La obra de arte en la época de su reproductibilidad técnica de 1936. Hoy en día, dicho aura, se ha perdido o ha cambiado de forma sustancial en el arte de masas. una Plastic Chair, Liz Taylor se sienta en una Plastic Chair, y piénsalo, tú también te puedes sentar en una Plastic Chair. No es que tengamos que imaginarlo o sea una probable suposición, todo esto ocurrió, y América lo vio.

En 1976 dos presidentes de los Estados Unidos mostraron a todo la nación que las posaderas presidenciales también hacían uso de las Plastic Chairs. No fue una ocasión cualquiera. Fue durante el debate presidencial entre el entonces gobernador Jimmy Carter y el presidente Gerald Ford, el segundo de la historia. Dieciséis años antes, en 1960, había tenido lugar el primero entre el candidato John F. Kennedy y el vicepresidente Richard Nixon y su emisión, como es bien sabido, había cambiado el rumbo de las elecciones. Con aquel precedente, la expectación en 1976 no fue menor, un 53,5\% de los hogares con televisión siguió el debate con motivo de aquel acontecimiento. ${ }^{32}$ También sabemos que Liz Taylor no pudo evitar sentarse en alguna versión de aquellas sillas. Igual que Jackie O., Marlene Dietrich, Ingrid Bergman y toda una abultada lista de famosas que sintieron la necesidad de retocarse el maquillaje como recuerda la Memorabilia del Aeropuerto Gander de Canadá. ${ }^{33}$ La parada para repostar en aquel aeropuerto era inevitable para todos los aviones que cruzaban el Atlántico en su conexión con Europa hasta mediados de los años 60 en el que el combustible para la aviación mejoró. El aeropuerto canadiense, un clásico del diseño moderno, fue amueblado con piezas del catálogo Herman Miller y entre ellas se escogió para equipar el aseo de señoras una larga fila de las sillas de fibra de vidrio de los Eames.

La conclusión podría ser: La silla está tan extendida, es tan común y tan ordinaria como la Coca-Cola. Sin extendernos más en ello, lo que podemos inferir de esta divagación por lo cotidiano es que esta silla ocupa una privilegiada situación en el imaginario colectivo. Cualquier objeto que pueda formar parte de un anuncio, un aeropuerto, un museo y un debate a la presidencia de los Estados Unidos no se puede considerar sino como un artefacto sofisticado y complejo. Esta sorprendente condición sitúa a la silla en el centro de uno de los dilemas modernos. Una perspectiva tradicional plantearía la pregunta en estos términos: ¿Puede una pieza de buen gusto soportar la envestida del consumo de masas sin que afecte a su aura ${ }^{34} \operatorname{Sin}$ embargo, una visión revisada podría plantearla en otros términos: ¿Qué 


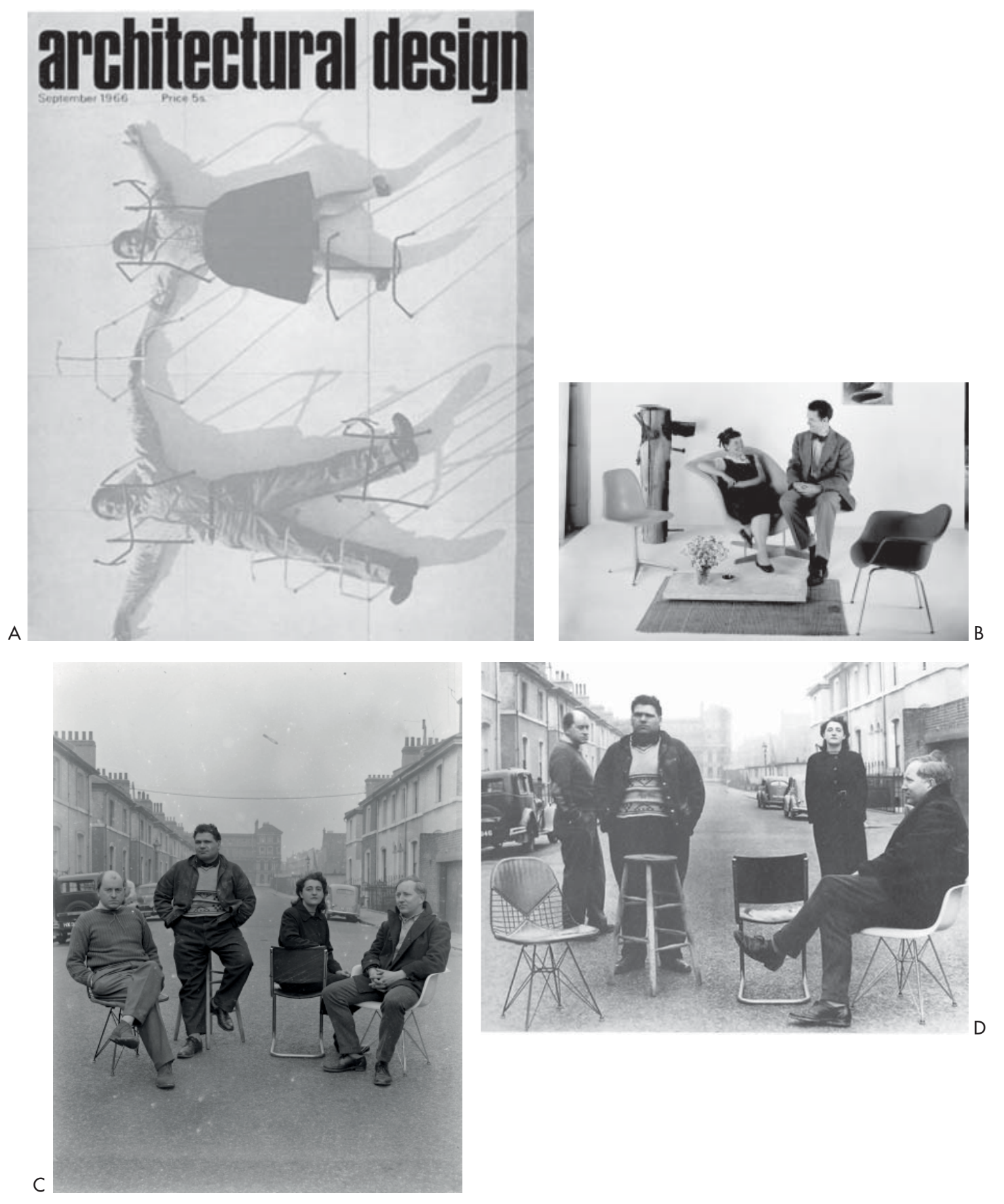


A. Portada del número especial dedicado a los Eames de la revista Architectural Design. Septiembre, 1966.

B. Charles y Ray Eames con prototipos para Low Cost Furniture Competition, 1948.

C-D. Alison and Peter Smithson con Nigel Henderson y Eduardo Paolozzi en Londres, 1956 mecanismos permiten a un objeto establecer continuidades y relaciones a tantos niveles sin agotarse en el proceso? ¿Cómo habita esta arquitectura con dos universos aparentemente distantes y opuestos? Son pocos los que pueden presumir de ser un lugar de paso o espejo del mundo, pero las plastic chair parecen uno de ellos.

\subsection{PLASTIC FURNITURE: LAS SILLAS-MUNDO ${ }^{35}$}

En Septiembre de 1966 Alison y Peter Smithson fueron los editores de un número especial de la revista Architectural Design dedicado al mundo de Charles y Ray Eames cuyo elocuente nombre era Eames Celebration. Devoción era sin duda uno de los sentimientos que les había empujado a realizar ese emocionado acto de generosidad en el que, a través de textos de diversos autores, buscaban celebrar a los diseñadores americanos. Just a Few Chairs and a House: an Essay on the Eames Aesthetic es uno de los textos con los que los Smithson participaban en la publicación. En él relatan como, durante los años cincuenta, el clima general del diseño habría cambiado para siempre con la obra de Charles y Ray Eames. Con unas pocas sillas, el "modo Eames" de ver las cosas se habría convertido, en cierto sentido, en el nuevo estilo:

"Las sillas siempre han sido las precursoras de un cambio en el mundo del diseño. Por alguna misteriosa razón, poseen la capacidad de establecer un nuevo sentido del estilo casi de la noche a la mañana. Rietveld estableció todo un nuevo modo de diseñar con una silla, al igual que hizo Mackintosh con la suya."36

35. Este apartado es un extracto de un artículo de mayor extensión publicado durante la investigación en la revista REIA también titulado Plastic Furniture: Las sillas Mundo. Navarro, 2014.

36. Smithson y Smithson, 2001: 72

37. The Shell es el nombre que utilizaron desde el origen para referirse a esta parte del asiento.

38. El origen de esta investigación se podría situar en el trabajo desarrollado por Charles Eames y Eero Saarinen para el concurso Organic Design in home Furnishings organizado por el Museum of Modern Art de Nueva York en 1940. Eames y Saarinen ganaron en la categoría de sillas y almacenamiento pero fue en la primea de ellas en la que destacó su diseño al presentar una propuesta radicalmente diferente a todo lo que se había visto hasta ese momento. El resultado, a pesar de las buenas críticas que recibió, fue agridulce ya que fueron incapaces de llevarlo a la fabricación en serie.
Es difícil imaginar las verdaderas ambiciones de los Eames y si entre ellas estaba cambiar el mundo del diseño, pero es evidente durante la primera parte de su carrera persiguieron con ahínco un objetivo preciso. A mediados de los años cuarenta los Eames decidieron que era el momento de empezar una investigación que les permitiera fabricar en serie la visión que años antes habían tenido de un asiento-cáscara ${ }^{37}$ y que se les había resistido con la técnica del contrachapado. ${ }^{38}$ Los Eames aprovecharon la oportunidad que ofrecía el concurso International Competition for Low-Cost Furniture Design organizado por el MoMA en 1948 para desarrollar un diseño que fuera 


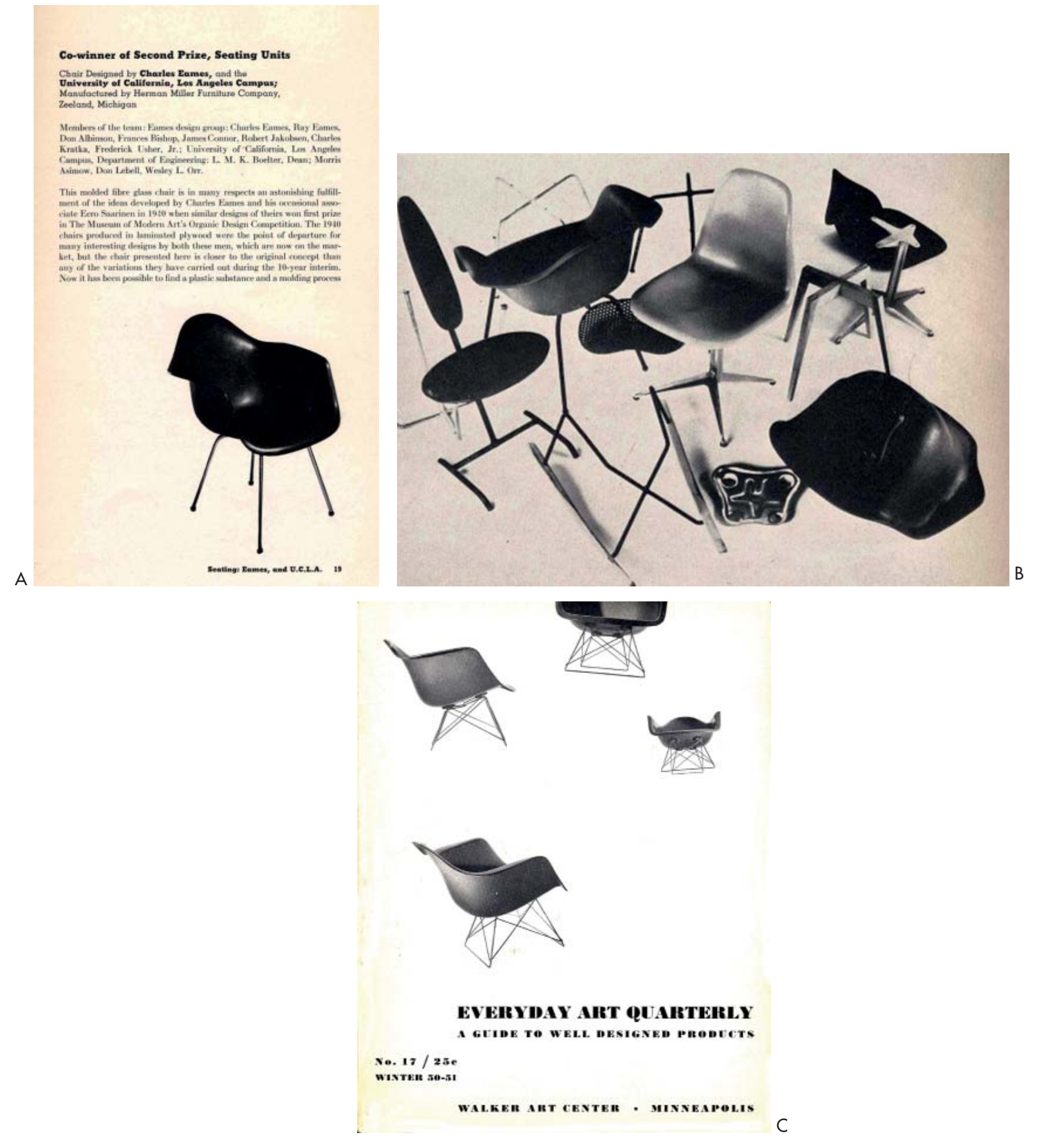


A. Publicación de premiados en el concurso International Competition for Low-Cost Furniture Design.MoMA, 1948.

B. Imagen del material presentado por los Eames al International Competition for Low-Cost Furniture Design. MoMA, 1948

C. Portada del Everyday Art Quaterly del Walker Art Center de Minneapolis, nº 17, Invierno, 1950

Diferentes vistas de las sillas de fibra de vidrio. capaz de proponer un mobiliario de bajo coste, eficientemente planeado y adaptado al consumo de las familias americanas. Fascinados por las suaves curvas de los guardabarros que salían de las fábricas de Detroit pensaron en la utilización de esa misma tecnología para su producción.

Los Eames obtuvieron en el concurso, según sus propias palabras, un decepcionante segundo premio. A pesar de ello el desarrollo de la silla continuó. Sin embargo los Eames tomarían una decisión trascendental, descartar el metal estampado por la dificultad en su fabricación y el alto coste y sustituirlo por un material que provenía del mundo de la aviación militar: la fibra de vidrio. El fruto a esos años de investigación recibió el nombre genérico de Plastic Furniture. La silla es el resultado de unir dos componentes visiblemente diferenciados: un asiento orgánico, the shell, de misteriosa translucidez cuyo peso era transferido desde cuatro puntos a una extensión, the supporting base, que contaba con diferentes versiones.

Esta decisión iba a suponer un cambio radical en la forma de pensar, diseñar y entender el mobiliario industrializado. Los Eames introducían en su propuesta una condición que desarmaba la unidad objetual de la silla y la desplazaba a un campo de posibilidades múltiples. Su apuesta era crear una colección de asientos intercambiables soportados por bases intercambiables. Era una audaz estrategia que permitía, por su combinatoria, generar una amplia gama de opciones. El repertorio inicial inclúa, para los asientos, dos modelos de superficie curvada que resolvían en continuidad asiento y respaldo: La Sidechair y la Armchair. De ambos se produjeron diversas versiones tintadas en color y tapizadas. La base también se pensó como un sistema de múltiples diseños que fueron incrementándose y cambiando en el tiempo. La H-base, X-base, la Wire strut and Sooden leg base, Wire cage base o la Eiffel Tower base son algunos de los prototipos que tuvieron más éxito. La posibilidad de permutación no solo ampliaba la versatilidad de uso sino que afirmaba la independencia entre las partes. En definitiva, la base y la carcasaasiento se comportaban como una combinación de elementos reconocibles y diferenciados.

La totalidad-silla es una agrupación de dos sistemas independientes que pueden ser descritos de forma autónoma desde su materialidad, su estructura, su técnica o sus mecanismos de relación con el entorno. Esta condición es 

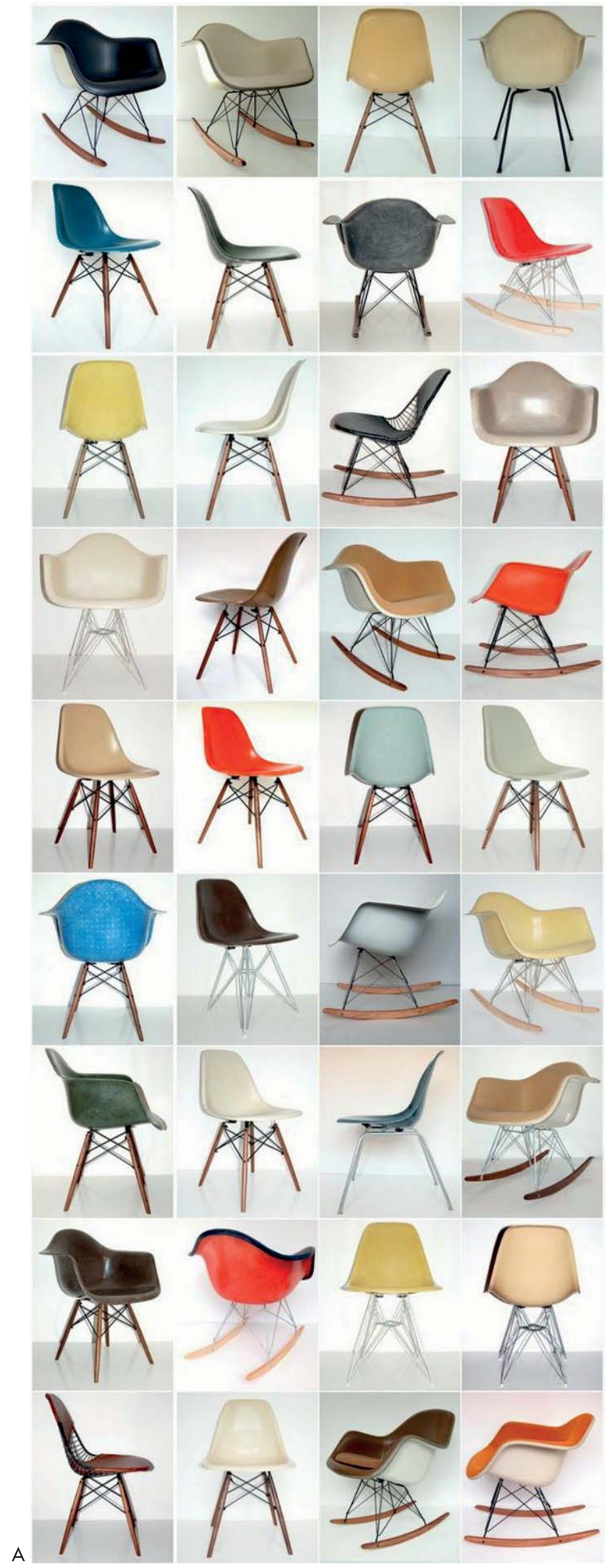
A. Charles y Ray Eames. Diferentes modelos de silla, Plastic Furniture. fundamental ya que es desde esta perspectiva como podemos empezar a pensar que la silla funciona como una agrupación heterogénea formada por dos entidades equiparables cuyos orígenes están en universos diferenciados. Es una relación entre iguales y distintos, sin subordinación o jerarquías, donde entre las partes simplemente existe una relación de oportunismo. Una descripción poco ortodoxa podría ver el resultado como la cita de dos individuos de tribus de naturaleza distinta que, contra todo pronóstico, han congeniado. Percibimos la tensión al mismo tiempo que entendemos que existe una afinidad. Una relación que solo puede admirarse desde la disparidad de ambas organizaciones.

Algunas de sus propiedades, como el material, la geometría o el color, fascinaron por su novedad. Como enunciaron los Smithson:

"Antes de los Eames, ninguna silla del canon moderno disfrutaba de varias versiones en color, ni resultaba ligera de peso, o era básicamente rectangular en planta, como las sillas de Rietveld, Stam, Breuer, Le Corbusier, Mies o Aalto.....” 39

La literatura en torno a la silla ha dedicado una atención extensa al asiento justificada en las innovaciones que aportaba con respecto a otras sillas precedentes. Pero, si queremos de verdad entender las complejas relaciones que entran en juego en la plastic furniture, debemos observar por igual ambas partes del objeto. En esta investigación pretendemos equiparar la importancia de ambos cuerpos, de ahí que primero queramos reivindicar la base como elemento esencial del diseño. Las bases de la plastic chair son el espejo de las expectativas que el usuario proyectaba en lo que suponemos que para muchos era un objeto extraño. La percepción de un artefacto leve y móvil no se debe tanto a las propiedades del asiento-concha sino a la ligereza que emana del trazado alámbrico de sus patas. Incluso podríamos añadir que la apariencia tensa y metálica ayuda por contraste a reafirmar el carácter orgánico y acogedor de la concha que recibe al usuario. La destrucción de la solidez de la silla se debe fundamentalmente a la extraña coexistencia del asiento y la base.

La condición múltiple de las Plastic Chair va más allá de la percepción visual o de un contraste entre materia o geometría. Cuando los Eames empezaron 

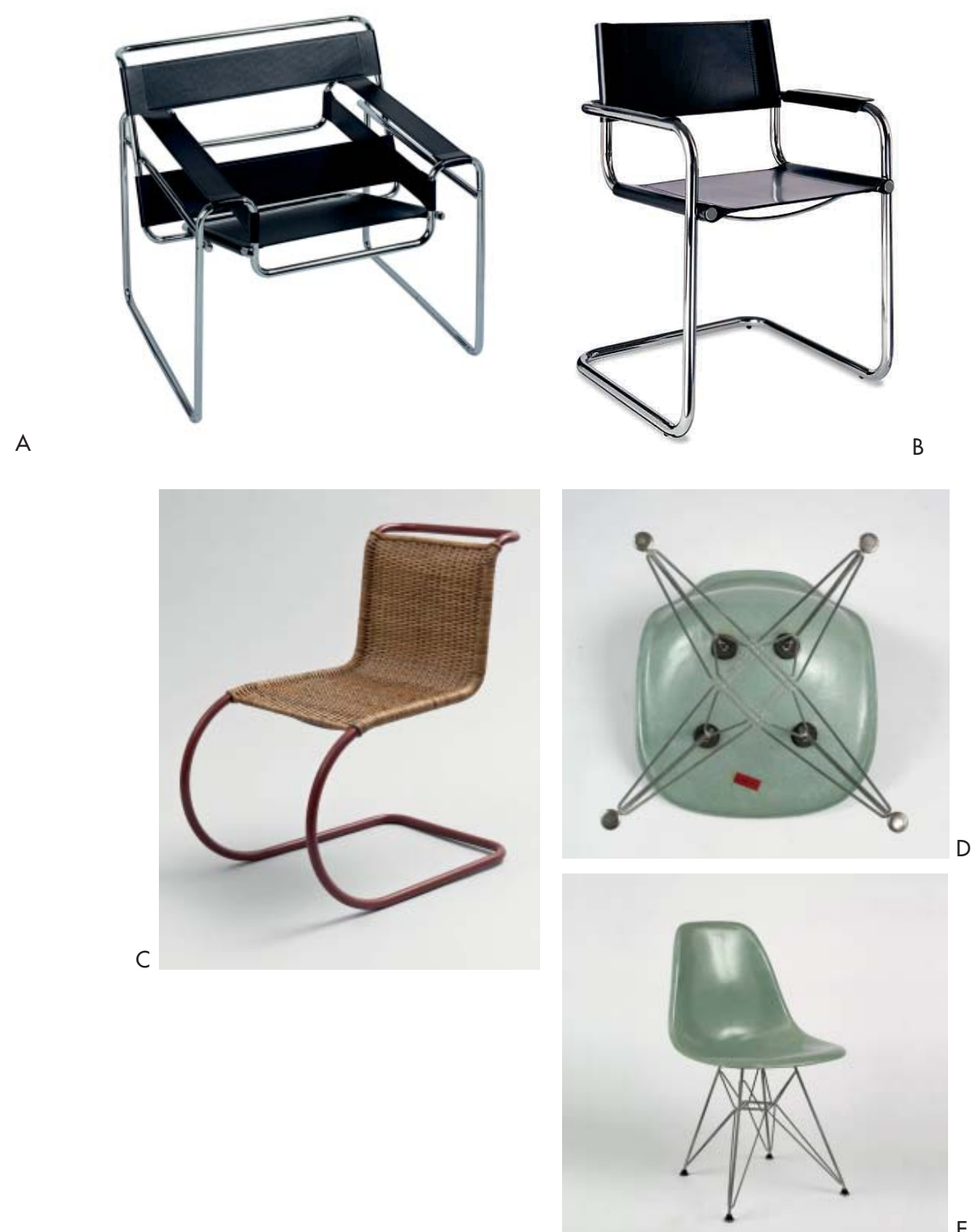

E 
A. Marcel Brever. Silla B3 Wassily (1925)

B. MartStam. Silla Cantilever (1926)

C. Mies van Der Rohe y Lilly Reich. Silla MRIO (1928).

D. Charles and Ray Eames. Plastic chair (1950). Vista inferior.

E. Charles and Ray Eames. Plastic chair (1950). a idear esta silla ya hacía años que otros diseñadores habían introducido la variedad de materiales en el diseño de mobiliario. La silla B3 Wassily de Marcel Breuer, La Cantilever chair de Mart Stam, o la MR10 de Mies van Der Rohe y Lilly Reich de 1925, 1926 y 1927 respectivamente son ejemplos de la combinación de las cualidades técnicas y constructivas del acero con la textura sensual y el confort del cuero. Sin embargo si las analizamos desde un punto de vista estructural, aunque audaces, las sillas de Breuer, Stam o Mies-Reich se siguen comportando como una unidad estructural, como un todo indisociable. Por el contrario, en el caso de las plastic chair existe una autonomía estructural que permite que las partes se puedan intercambiar. La base y el asiento utilizan para la distribución de las fuerzas lógicas estructurales opuestas. Por un lado, el asiento forma una membrana de fibra de vidrio en la que se reparten los esfuerzos del peso del cuerpo al mismo tiempo que la geometría de doble curvatura aporta resistencia. Por un lado la base crea un entramado de elementos lineales de madera o acero que unidos son capaces de trasmitir las fuerzas al suelo. Ambas estructuran se conectan siempre en los mismos cuatro puntos. Esta solución permite que sea exclusivamente la base, según su altura y ángulo, la que aporte la diversidad de posturas a la silla. Para permitir esta sutil coexistencia los Eames aprovecharon lo que resultó ser uno de los más ingeniosos avances de la historia del diseño de mobiliario: los 'amortiguadores ${ }^{40}$ elásticos de goma. Independientemente de cuál fuera la base o cual fuera el asiento todos los modelos contaban con cuatro discos flexibles que, adheridos a la parte inferior de la cáscara, permitían atornillar la base elegida sin perforar la fibra de vidrio a la vez que permitía absorber los esfuerzos locales en la unión mediante una articulación.

Esta dualidad e independencia estructural se hace visible tanto en el uso de la silla como en la manera en la que los Eames las mostraban disociadas. Entre la documentación gráfica producida por la oficina de los Eames es habitual encontrar imágenes en las que se hace explícita la autonomía de las partes y son numerosas las reproducciones en las que de forma intencionada estas se muestran por separado. Tomemos referencia el libro Eames Design ${ }^{41}$, la mítica publicación que resume su prolífica obra y que fue editado por John Neuhart y Marilyn Neuhart con la participación de la propia Ray Eames. El también llamado Black Book, organiza cronológicamente el trabajo producido año a año por la oficina. En él aparecen en diversos periodos imágenes en las que 

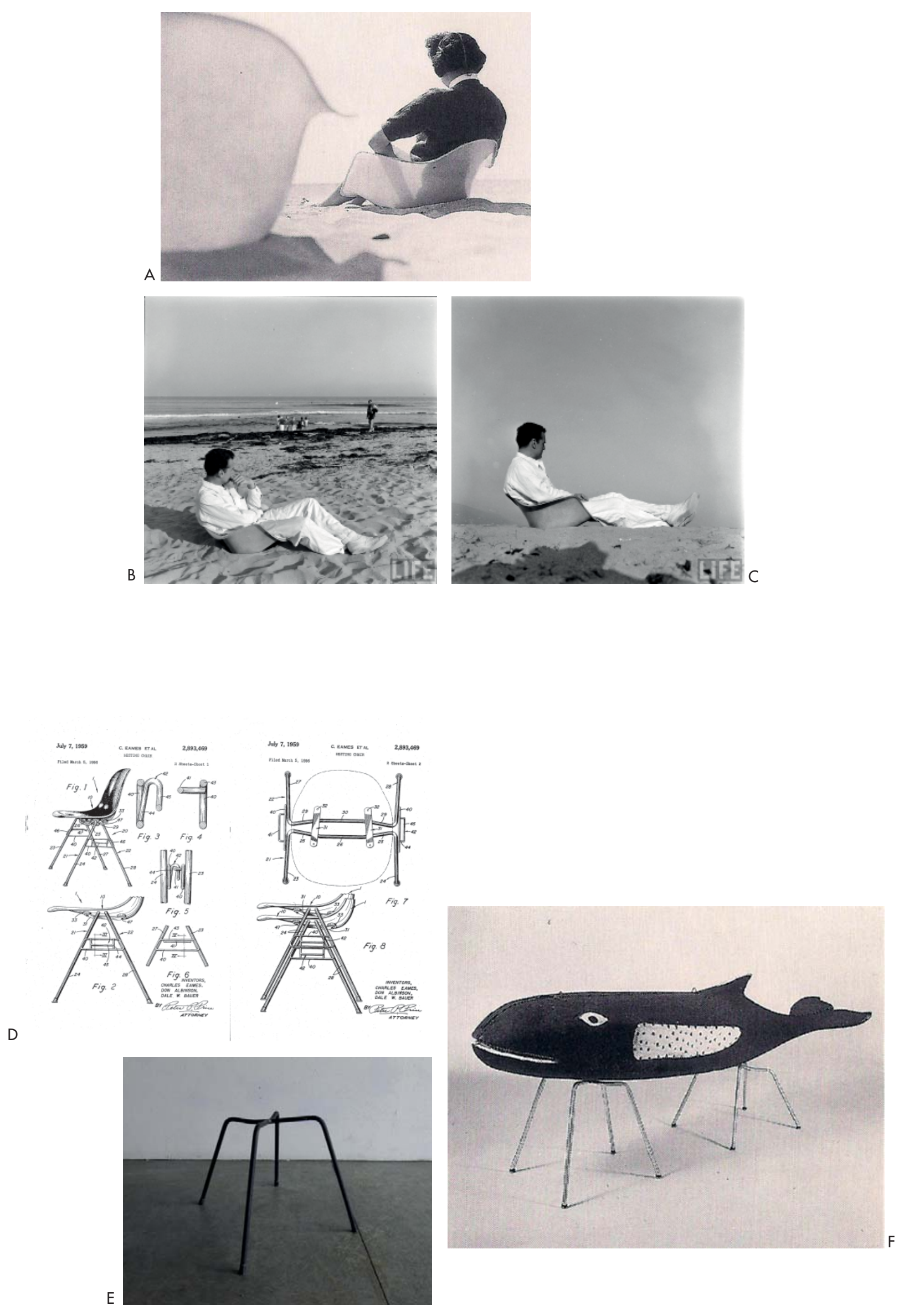
A. Verla Shulman sentada en la concha de una Armchair, 1950.

B-C. Charles Eames sentado en la concha de una Armchair, sobre 1950.

D. Charles y Ray Eames. Dibujos para la patente de la silla Nesting Chair.

E. Charles y Ray Eames. Estructura de patas de los modelos DAX, SAX, LAX Armchair.

F. Escultura de una ballena apoyada sobre dos de las bases de las plastic chair, 1952. se retrata la base y la carcasa-asiento de forma independiente. Seguramente la imagen más esclarecedora se encuentra en la tercera página dedicada a las plastic chair fechada en $1950^{42}$. La fotografía muestra a Verla Shulman, la por mucho tiempo secretaria de la oficina, de espaldas sentada en la concha de una Armchair que, prescindiendo de cualquier tipo de base, se apoya directamente sobre la arena de la playa. La imagen es evocadora por su belleza y por lo que representa. Al menos Ray y los Neuhart también lo debieron ver así. La fotografía ocupa la esquina superior derecha, la posición que, tras un atento repaso al libro, se revela como el lugar reservado en la maquetación para, de forma sutil, realizar tributos o celebrar acontecimientos. Como ha indicado Beatriz Colomina, a los Eames les gustaba celebrar las cosas. Cualquier cosa. Todo. No era simplemente una frivolidad, una distracción del trabajo, era parte del trabajo mismo. ${ }^{43}$ Podemos imaginar por lo tanto que mostrar esta imagen era también una forma de celebrar la posibilidad de que cada componente reivindicara su libertad. En la instantánea se despliegan evocadoramente las propiedades de la silla. A través de la actitud relajada de la protagonista se hace evidente su comodidad y ergonomía. También su ligereza se adivina en la sombra del cuerpo que queda proyectada sobre la translúcida fibra de vidrio. Pero quizá lo que la hace más especial es que la carcasa se ha asociado con la arena de la playa para encontrar el ángulo y el soporte adecuado. El asiento-carcasa reposa sobre la arena, inclinado suavemente. La fotografía muestra un asiento emancipado que ha accedido a un espacio de autonomía ajeno a las leyes convencionales del todo-silla. No fue tampoco la última, en otra ocasión, para ilustrar un artículo en la revista LIFE, Charles Eames fue fotografiado haciendo uso de esta peculiar versión de playa de la plastic furniture. No era una foto privada, esta vez la mostraban de forma consciente a todo un país, para que no quedara duda de su autonomía.

A la inversa podríamos realizar una aproximación similar con respecto a las bases. Otra vez en el Black Book, unas páginas más tarde, cuando reseñan el showroom realizado para la compañía Herman Miller en 1952, aparece otra imagen explícita. Ocupando otra vez el mismo lugar, la esquina superior derecha, se muestra un instante del montaje de la instalación del espacio comercial. La fotografía capta el momento en el que la escultura de una ballena realizada por los indios del Pacífico Noroeste, una de las piezas de folk-art americano preferidas por los Eames, se encuentra apoyada sobre dos
42. Ibid.: 141

43. Colomina, 2007 

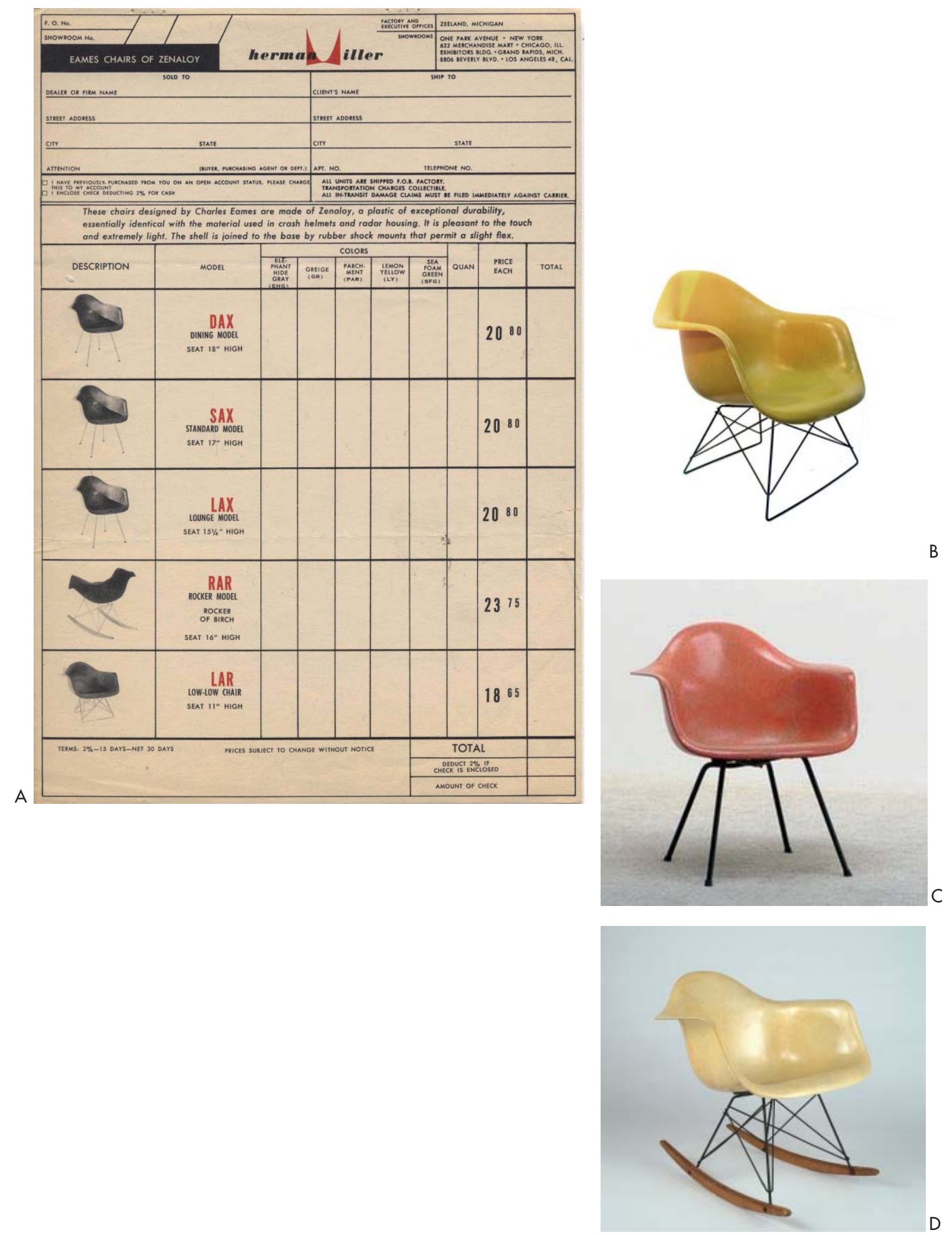
A. Charles and Ray Eames. Ficha del producto con la variedad de las sillas concha DAX, MAX and the LAX (Armchairs) con sus diferentes alturas (1950). B. Charles and Ray Eames. Fiberglass Shell Chair, LAR Model (Armchair).

C. Charles and Ray Eames. Fiberglass Shell Chair DAX, MAX, LAX Model (Armchair).

D. Charles and Ray Eames. Fiberglass Shell Chair RAR Model (Armchair) de las bases de tubo metálico de las plastic chair a la espera de ser ubicada. ${ }^{44}$ Los Eames vuelven a celebrar lo cotidiano a través de esta instantánea y, de forma simultánea, nos revelan la deriva autónoma de la base.

Ambas situaciones se vuelven aún más esclarecedoras si intentamos recordar algún otro caso en el que aparezca una silla de la modernidad voluntariamente descuajeringada. Acaso alguno de sus diseñadores hubiera aceptado que esas imágenes formaran parte de su catálogo razonado. Por el contrario, los Eames lo hicieron, celebraron la heterogeneidad de su diseño y mostraron asiduamente la disolución de la totalidad-silla. Peter Smithson lo resumía en otra concisa apreciación sobre las sillas de los Eames:

"Se ha vertido mucha energía en sus detalles.... Se pueden fotografiar como fragmento y se pueden disfrutar como fragmento." 45

Y podríamos añadir que cada uno de esos fragmentos, no solo se hace explícito desde la forma sino que también convoca un mundo específico de referencias. Por lo tanto no debemos entender el conjunto de la plastic chair como la consecuencia de recombinar de trozos parciales sino como la resultando de dos mundos ensamblados. Cada una de las partes que compone la totalidad-silla convoca un contexto cultural específico y construye un mapa propio de referencias. Como nuevamente nos hacen ver los Smithson, estas sillas son capaces de recordarnos al mismo tiempo a los aeroplanos nuevos y a los viejos. Reúnen en un mismo lugar la tecnología de la bicicleta y la aerodinámica de la automoción. Las partes se enlazan en una especie de conversación que desafía el concepto de lo Uno y de la unidad. 

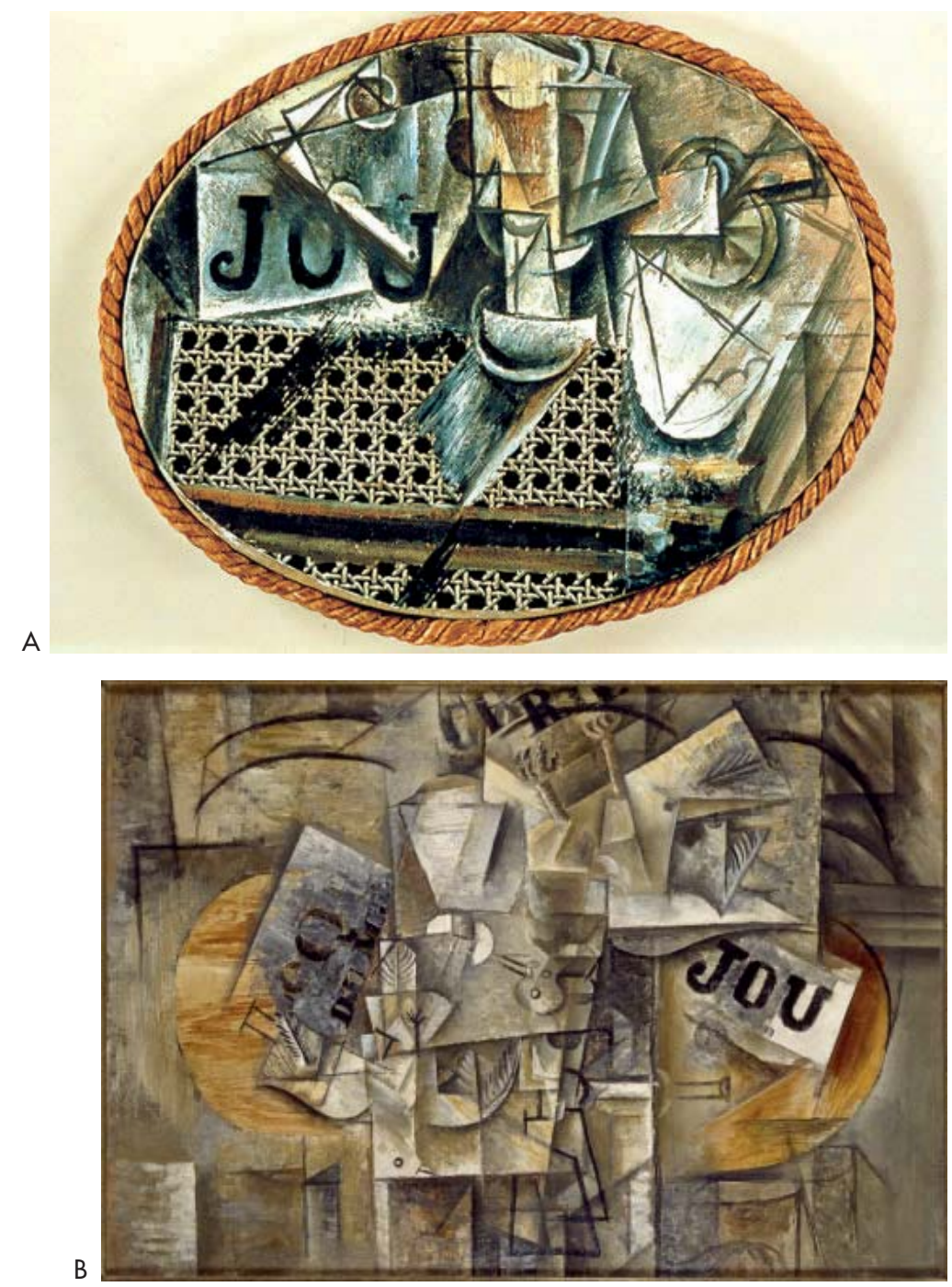


\subsection{COMBINACIÓN Y MONTAJE: LANGUAGE OF VISION}

A. Pablo Picasso. Bodegón con Caña de Silla (1912).

B. Pablo Picasso. Los Pájaros Muertos, Museo Nacional Centro de Arte Reina Sofía (1912).
46. Shields, 2014: 2

47. Pallasmaa, 2102: 158

48. Rowe y Koetter, 1978: 144
Si la silla de los Eames se puede describir como una arquitectura que funciona como una agrupación heterogénea, es quizá el momento de entender la herramienta proyectual a través de la cual las plastic furniture fue diseñada. Profundizar en los mecanismos que se despliegan en la silla es también bucear en el universo de Charles y Ray Eames. Es fácil vislumbrar tanto en lo intelectual como en lo estético la influencia de las vanguardias europeas. Desde sus estudios universitarios, ambos estuvieron bajo la órbita de las pedagogías procedentes de la Bauhaus y a ellas deben mucho de su manera de proyectar y de pensar. Por eso tiene sentido empezar por rastrear aquellas técnicas que trabajan por la acumulación de lo diverso. Empecemos por los sospechosos habituales.

A lo largo del siglo XX se ha vinculado la arquitectura compuesta a la tradición del collage. No son pocos los libros que han tratado el tema y los que han mostrado los cambios sustanciales de los procesos creativos tras su aparición. Como ha indicado Jennifer Shields, ${ }^{46}$ el collage es un arte específico de la era moderna que enfatiza el proceso sobre el producto; una obra de arte que consiste en ensamblar varios fragmentos de materiales de tal manera que la combinación tiene un sentido nuevo y diferente. El collage tiene múltiples niveles de significado: la identidad original del fragmento u objeto y toda la historia que trae con él; el nuevo significado que el objeto obtiene al asociarse con otros objetos o elementos; y el sentido que adquiere como resultado de su metamorfosis en una nueva entidad. Otros se han aproximado al tema en términos parecidos al referirse al arte del collage y assemblage como una técnica artística capaz sugerir por la yuxtaposición poética de imágenes una materialidad sutil e inesperada, un tiempo estratificado y no lineal y una arqueología de las narrativas de los fragmentos. ${ }^{47}$ También se ha querido ver en el collage un modo de transgredir y alterar la ortodoxia de la modernidad. Así Collin Rowe y Fred Koetter lo proponen como una herramienta subversiva heredera de la ironía a través de la cual deshacer la visión mesiánica del modelo de ciudad moderna e incorporar la ciudad tradicional con una intención pluralista. Una técnica para utilizar cosas sin acabar de creérselas, y también una estrategia que puede permitir tratar la utopía como imagen, tratarla en fragmentos sin que tengamos que aceptarla in toto. ${ }^{48}$ 

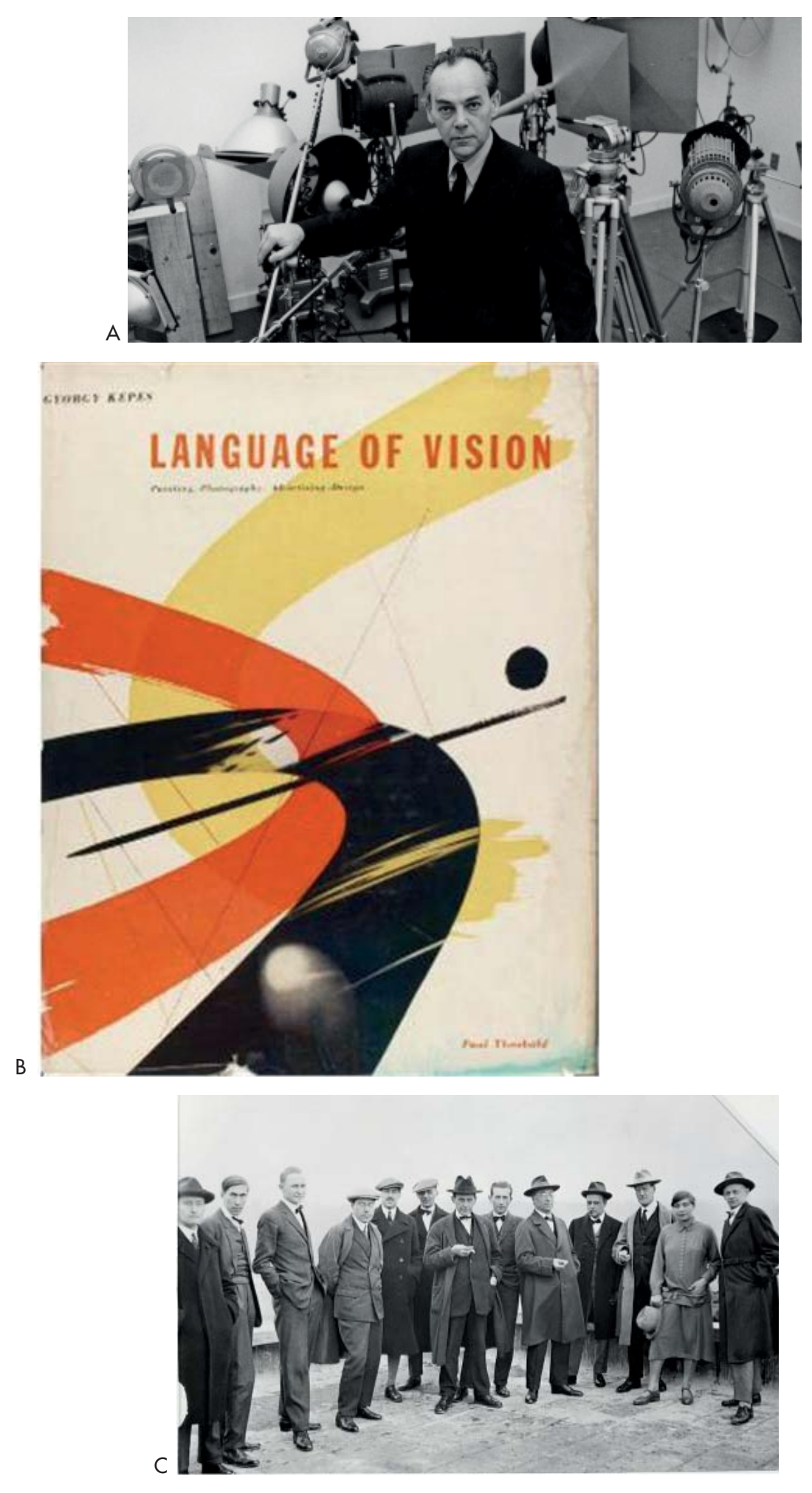
A. Gyorgy Kepes (1906-2001).

B. Gyorgy Kepes. Language of Vision (1944).

C. De izquierda a derecha: Josef Albers, Hinnerk Scheper, Georg Muche, László Moholy-Nagy, Herbert Bayer, Joost Schmidt, Walter Gropius, Marcel Brever, Vassily Kandinsky, Paul Klee, Lyonel Feininger, Gunta Stölzl and Oskar Schlemmer Bauhaus, Weimar, 1919

49. Transcripción parcial de la conferencia dada por Charles Eames y que se encuentra en "Design Seminar at the American Iron and Steel Institute", Atlanta, Georgia, lecture notes WCRE, Box 217, Folder 15. Lai ,1999: 35.

50. Ibid.
Aunque sin duda podamos establecer ciertas conexiones con la tradición del collage, una mirada atenta a la silla muestra una distancia visible con la técnica que inició George Braque en 1912. La plastic chair no se comporta exactamente como una agrupación de fragmentos combinados, no son partes extraídas de unos 'otros' reunidas a través de medios y principios de composición. Por el contrario, en la plastic chair cada una de las partes se comporta como una entidad autónoma, conectada con mundos externos pero sin deberles una continuidad, sin ser su extensión. Frente al recorte de periódico del collage, que deja su hueco en el periódico del que proviene haciendo evidente su sentido de pertenencia a otro lugar, las piezas del todo-silla reclaman su singularidad e integridad. Tampoco la silla emerge por una simple composición formal sino que, como veremos, anida en ella una estrategia proyectual más rica, más compleja. Podríamos decir que lo que subyace es una forma de pensamiento relacional frente a un pensamiento objetual. Así lo enunciaba literalmente Charles Eames en 1975, en la conferencia que dio en el Design Seminar del American Iron and Steel Institute de Atlanta, citando a Samuel Ichiye Hayakawa:

"Visually, the majority of us are still "object-minded" and not "relationminded". That was written in 1944, and I think that - (not because of any profound philosophical change) all sorts of things have been teaching us to read a scene in terms of relations. ${ }^{49}$

Aunque las palabras que toma Charles Eames son de S.I. Hayakawa, la referencia en origen se encuentra en el prólogo al libro Language of Vision de Gyorgy Kepes publicado en 1944 y cuya influencia en las obra de los Eames fue fundamental como ha señalado Constance C. Lai. ${ }^{50} \mathrm{El}$ vínculo se remonta a su época de estudiante. En 1937 la inestabilidad en Europa llevó a que importantes miembros de la Bauhaus Alemana emigraran a los Estados Unidos. Entre ellos se encontraban Walter Gropius, Mies van der Rohe, Herbert Bayer, Làszlò Moholy-Nagy, Gyorgy Kepes y Joseph Albers. Debido a la presencia de estas grandes figuras y su papel influente en las universidades, el pensamiento de la Bauhaus y las teorías de la Gestalt rápidamente se generalizaron tanto en los programas docentes de las universidades como en el diseño corporativo de empresas. Esto supuso un cambio importante con respecto a la tradición Beaux-Arts que hasta ese momento había sido tradicional en las escuelas americanas. La diferencia 

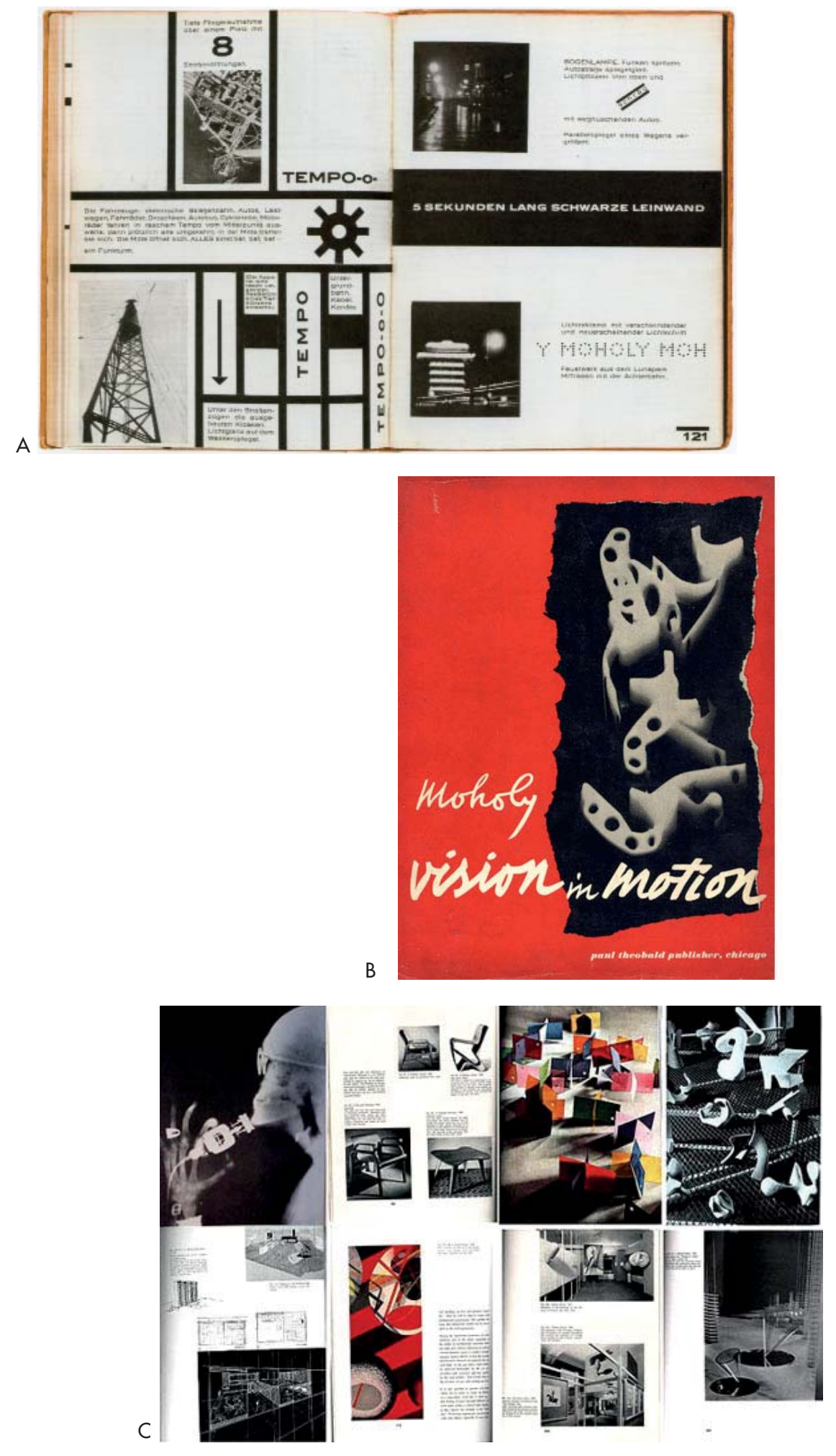
A. Laszlo Moholy-Nagy. Dynamic of the Metropolis (1921-1922).

B-C. Laszlo Moholy-Nagy. Vision in Motion (1947).
51. Hay que decir que este reconocimiento no significó la equiparación de estatus de los movimientos artísticos occidentales. De hecho, el arte de las culturas no occidentales fue comparado con el "arte" producido por los niños occidentales, en una glorificación del ojo deseducado de la inocencia y el primitivismo. Lai ,1999: 28 52. Kirham, 1995: 207 no solo era formal sino también filosófica. La Bauhaus buscaba un sistema de signos que fuera natural y universal, favorecido por las facultades biológicas de la percepción. La idea de este lenguaje visual no solo derivó en una depuración y racionalización de las formas sino que en cierto modo reivindicó el valor de las culturas no occidentales y especialmente su arte. ${ }^{51}$ Este tipo de enseñanzas se manifestaron posteriormente en muchos de los trabajos de los Eames. Es habitual encontrar episodios en los que su fascinación por las culturas indígenas y precolombinas o por la cultura popular y las manifestaciones de la infancia se alinean y dialogan con el mundo del arte, la matemática o la industria.

En ese ambiente receptivo, Làszló Moholy-Nagy y Gyorgy Kepes, fueron invitados en 1937 por la Association of Art and Industry de Chicago para que fundaran en esa ciudad una nueva escuela de diseño. Bautizada en un primer momento New Baubaus acabaría siendo, tras diversos cambios de nombre, lo que hoy conocemos como el IIT Institute of Design. Por aquellas fechas, Charles Eames estudiaba en Cranbrook, no muy lejos de Chicago, lo que le permitía visitar en los fines de semana a Moholy-Nagy y a Kepes. ${ }^{52}$ Le interesaban especialmente sus investigaciones sobre percepción y la Gestalt y seguía con atención su pensamiento. Al poco tiempo de aterrizar ambos profesores publicaron dos libros fundamentales: Language of Vision de Gyorgy Kepes de 1944 y Vision in Motion de Moholy-Nagy de 1947. Ambos libros proponían caminos para dotar de racionalidad científica al "lenguaje de la visión". Los libros situaban dos discursos culturales aparentemente divergentes en un mismo marco: ciencia y arte. La ciencia fue estetizada por su asociación con en el arte, mientras que el arte tomo prestado un cierto sentido de autoridad de la ciencia. La coincidencia de las fechas con el libro de Kepes -la publicación del libro es apenas cuatro años anterior al desarrollo de las sillas- así como la influencia que tuvo en el desarrollo de las teorías de la comunicación en sus posteriores trabajos nos hacen pensar que muchas de las decisiones de los Eames en el desarrollo de la plastic chair estarían directamente influenciadas por las ideas de Kepes.

En Language of Vision Kepes hace un repaso por la historia de la imagen, descifrando los mecanismos de la percepción. En sus últimas páginas estudia la desintegración de los sistemas fijos de organización de significado que tienen lugar en el siglo XX. En los conglomerados de su tiempo, ya 

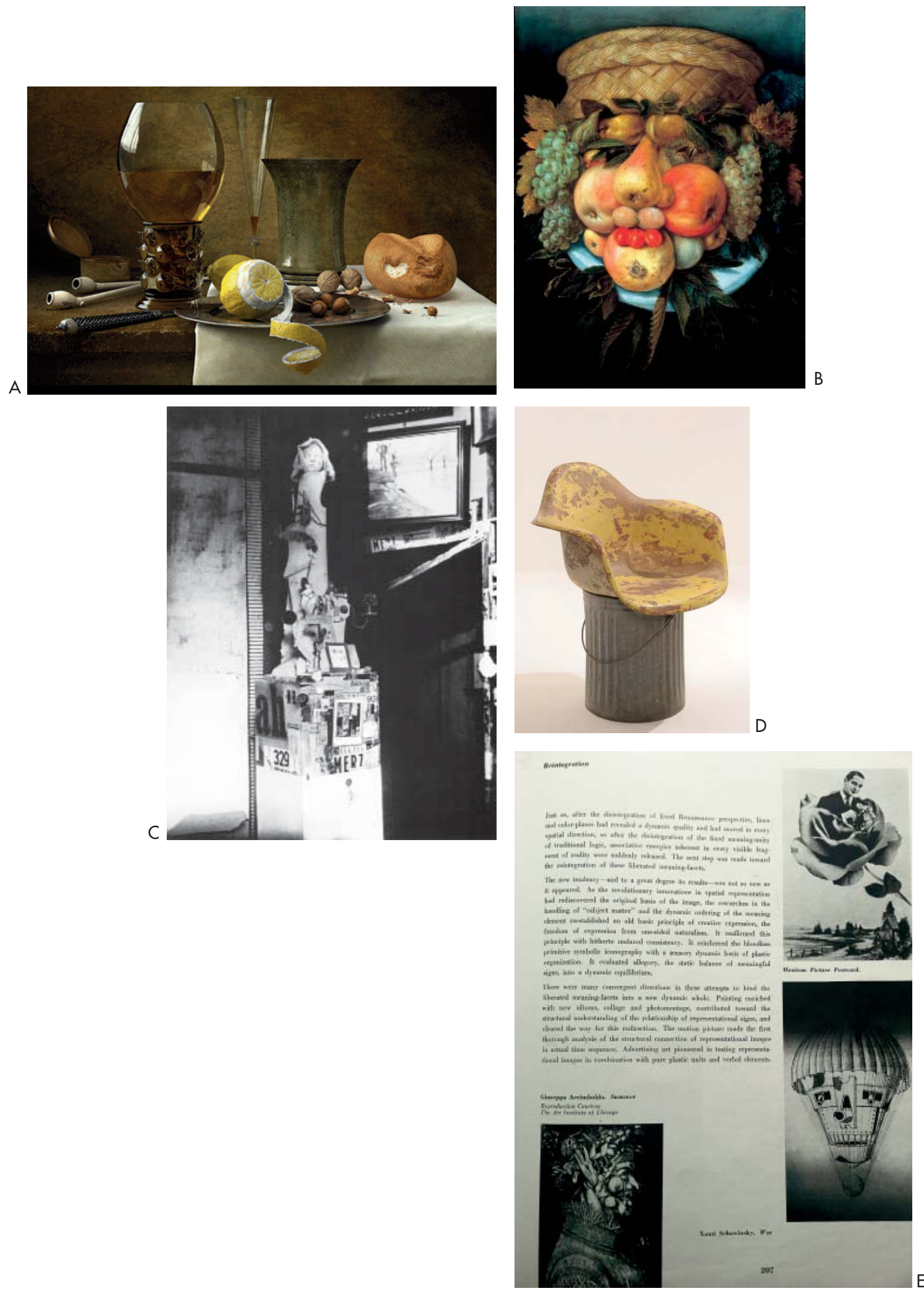
A. Willem Claeszoon Heda. Still life (1634).

B. Collage

C. Merz

D. Charles Eames. Asiento fiberglass shell sobre

cubo de basura, producido en el estudio de John

Wills, Arcadia, California (1948-1949).

E. Collages sean los del dada, los merzs de Schwitters, los collages o los fotomontajes, el observador es forzado a encontrar un nuevo orden en los fragmentos, y a rastrear conexiones latentes. Cuanto más alejados en significado y más difícil resulta encontrar una conexión entre las partes, mayor es la tensión del espectador mientras lucha por hallar una forma de vínculo entre ellas.

Al entender el modo de operar que tiene lugar en esas obras, Kepes advierte como los nuevos artistas se habrían reencontrado con un principio básico de la expresión creativa que tendría sus raíces en la alegoría, una manera de mostrar lo abstracto o hacer "visible" lo que solo es conceptual. El salto de los nuevos creadores en la utilización de esta herramienta se encontraría en haber ampliado su campo lingüístico al combinar representaciones visuales con formas puramente plásticas y unidades verbales. Color, forma, textura, línea y símbolo alcanzan una unidad orgánica y por lo tanto capacitan al espectador a formar con la obra un todo orgánico. ${ }^{53}$ Como resultado de la observación, el espectador obtiene una experiencia sensorial en la que la estructura dinámica de la imagen visual implicaría también un reajuste del pensamiento. Para Kepes, con estos procesos creativos el sistema nervioso se estaría entrenando para adquirir la disciplina de las dinámicas de la vida contemporánea. En definitiva, una herramienta de expresión moderna para una vida moderna.

También Moholy-Nagy dedicó en su libro Vision in Motion un capítulo específico al montaje, en este caso el cinematográfico. Elogiaba las propiedades de una herramienta capaz de establecer una coherencia a través de la adición de secciones de filmes. Celebraba la posibilidad de crear con los retales de película una historia jamás ocurrida. Rodar San Francisco y Chicago para narrar Nueva York. Tomar el registro del mundo para trocearlo y recomponerlo de una forma nueva y nunca vista. El arte en todo este proceso reside en cómo se anuda la trama, en no perder el ritmo, en conseguir que se desarrolle la acción sin que decaiga la expectación. Lo importante no es tanto enlazar escenas con invisible continuidad sino al contrario provocar mediante los saltos vibrantes y contrastados emociones fuertes en el espectador. Moholy-Nagy escribe:

"Motion pictures are the assemblage of numerous shots. A film scene is spliced, glued together from different parts. This is called film "cutting" (montage)" 


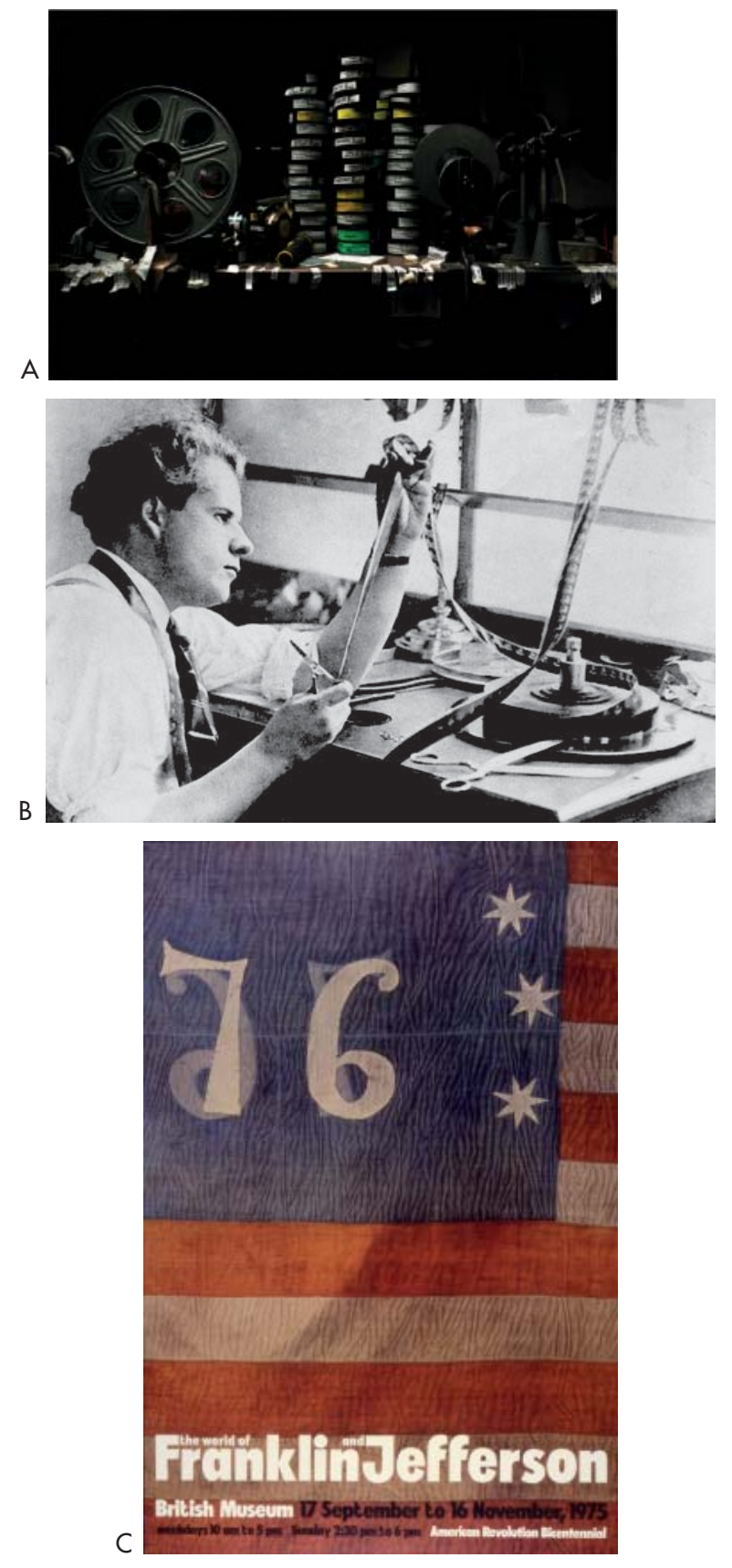


A. Mesa de montaje.

B. Sergei M. Eisenstein. Mesa de montaje, sobre 1928.

C. Charles y Ray Eames. Diseño del cartel de la exposición The world of Franklin and Jefferson (1975).
Moholy-Nagy aludía en su texto a la doble designación que recibía esta técnica. Por un lado, la francesa montage, que apunta a la acción de armar lo que proviene de diversas fuentes. Por otra la americana, cutting, que nos dirige a la de cortar o separar. Es la misma operación pero una monta y otra desmonta. Moholy-Nagy con su aclaración nos advierte veladamente de este desdoblamiento. No puede ser de otra forma, el montaje es una acción traumática, en el sentido de que muestra la fractura y deja su huella. No es una herramienta de sutura, no borra la herida. Al revés, hace evidente la cicatriz. En cierto modo es lo opuesto al medio de la filmación. Frente al proceso químico que fija la continuidad mediante el registro sensible de la película por la acción de la luz, emerge el montaje, puramente físico, donde no hay reveladores ni cambios de estado, sino el ritmo de lo dispar acompasado.

Los Eames vieron las innumerables posibilidades del montaje para trasmitir información con densidad y de forma dinámica, lo que les permitió a lo largo de su larga carrera derribar innumerables fronteras entre el arte y las ciencias; entre formas de representación; entre alta y baja cultura; entre educación y vida. Fueron muchas las ocasiones y muchos los modos en los que trabajaron con el despliegue de la multiplicidad. Son conocidos sus densos diseños expositivos, epítomes de la acumulación y relación de la información. Ejemplos como Mathematica. A world of numbers and Beyond o The world of Franklin and Jefferson supusieron una transformación en el formato de la exposición tradicional. También aparecieron en sus películas donde sus investigaciones por perfeccionar la proyección de films y diapositivas les llevo a inventar su propio proceso de montaje llamado fast-cutting que consistía en la consecución de imágenes a gran velocidad y por el que los Eames ganaron un Emmy Awards en 1960. Pero quizá la más reveladora la realizaron con motivo de la exposición Glimpses of the USA en 1959.

El proyecto surgió como un encargo para un delicado asunto de estado, la realización de una película para el primer intercambio cultural entre Estados Unidos y la Unión Soviética. El objetivo era mostrar un día en la vida del país americano. Lejos de conformarse con hacer una filmación convencional, los Eames apostaron por un ambicioso proyecto de multi-proyección. Utilizaron siete enormes pantallas de seis por nueve metros suspendidas en la cúpula geodésica de Buckminster Fuller. Dos mil doscientas imágenes 

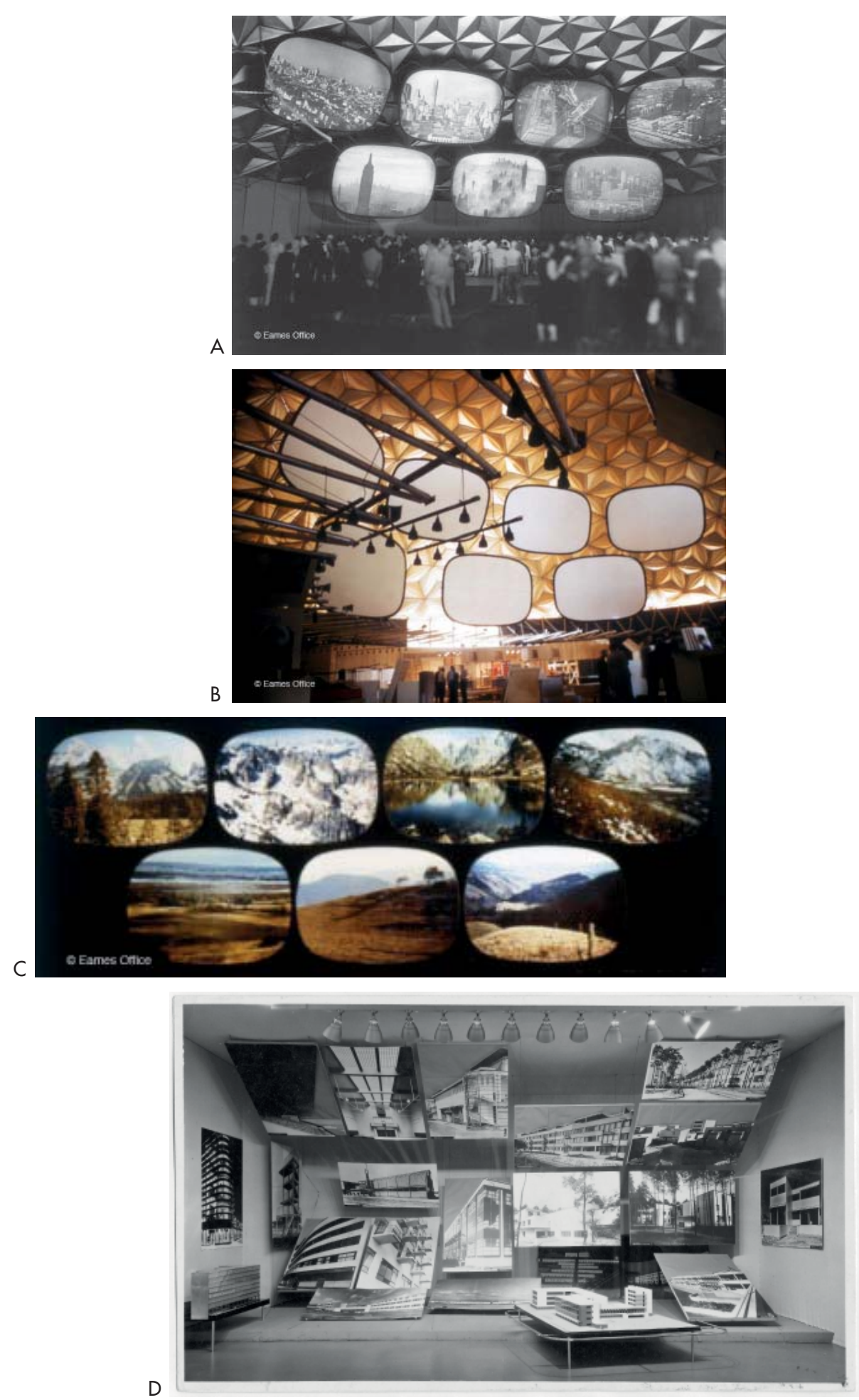
A-C. Charles y Ray Eames. Glimpses of the USA (1959).

D. Herbert Bayer. Diagram of Field of Vision (1930)
54. La cita original pertenece a la charla que mantuvieron Digby Diehl y Charles Eames en 1972. Colomina, 2007: 13 fijas y móviles se montaron para excitar los ojos rusos con las maravillas de la américa cotidiana. El éxito fue enorme, la cuidada elección de las imágenes, el ritmo y el tono familiar encandilaron al público ruso. Más de dos millones de personas sucumbieron a la experiencia. Los Eames habían creado un arma de seducción masiva. Charles Eames poco después de esta experiencia dijo:

“Habiendo descubierto el uso de imágenes múltiples, mostrábamos una tendencia a encontrar nuevos usos de ella. Si le das un martillo a un niño, encontrará que todo lo que ve necesita ser martilleado. Nosotros llegamos a la conclusión de que todo lo que encontrábamos necesitaba una técnica de imagen-múltiple... Utilicé el proceso con triple diapositiva en las Conferencias Norton en Harvard, para dar profundidad a la mirada. En cada conferencia hablaba durante cinco minutos y luego mostraba tres minutos de imágenes, y luego volvía a hablar otros siete minutos" ${ }^{\prime 54}$

En realidad ya hacía mucho que habían empezado a utilizar la multiplicidad para mostrar información. En la primavera de 1952, George Nelson, Charles Eames y Alexander Girard se hicieron cargo de una sala de conferencias del edificio de la Facultad de Química de la University of California, Los Angeles para realizar una experiencia docente expandida sobre el tema de "el arte como una forma de comunicación". The Sample Lesson, como es conocida, utilizaba un sistema expositivo, heredero de las investigaciones que Herbert Bayer había desarrollado en 1930 con su Diagram of Field of Vision, dónde paneles con múltiples imágenes de diferentes formatos mostraban la información de forma simultánea.

Como hemos visto, los Eames encontraron la forma de utilizar el montaje de un modo expandido, siempre para romper el marco estático y unitario de las disciplinas en las que trabajaban. Desbordaron los límites de la fotografía, cinematografía, arquitectura para ubicarse en paradigmas híbridos, en la intersección de diferentes disciplinas. La diversidad de campos -mobiliario, ciencia, matemáticas, ordenadores, estética, tecnología, fotografía, exposiciones, juguetes y películas- les obligo a buscar formas con las que operar en la heterogeneidad y la simultaneidad. Los hallazgos en uno de esos territorios no tardaban en saltar a otro. Su proceso creativo, en cierto, modo era un montaje, la plastic chair también. 

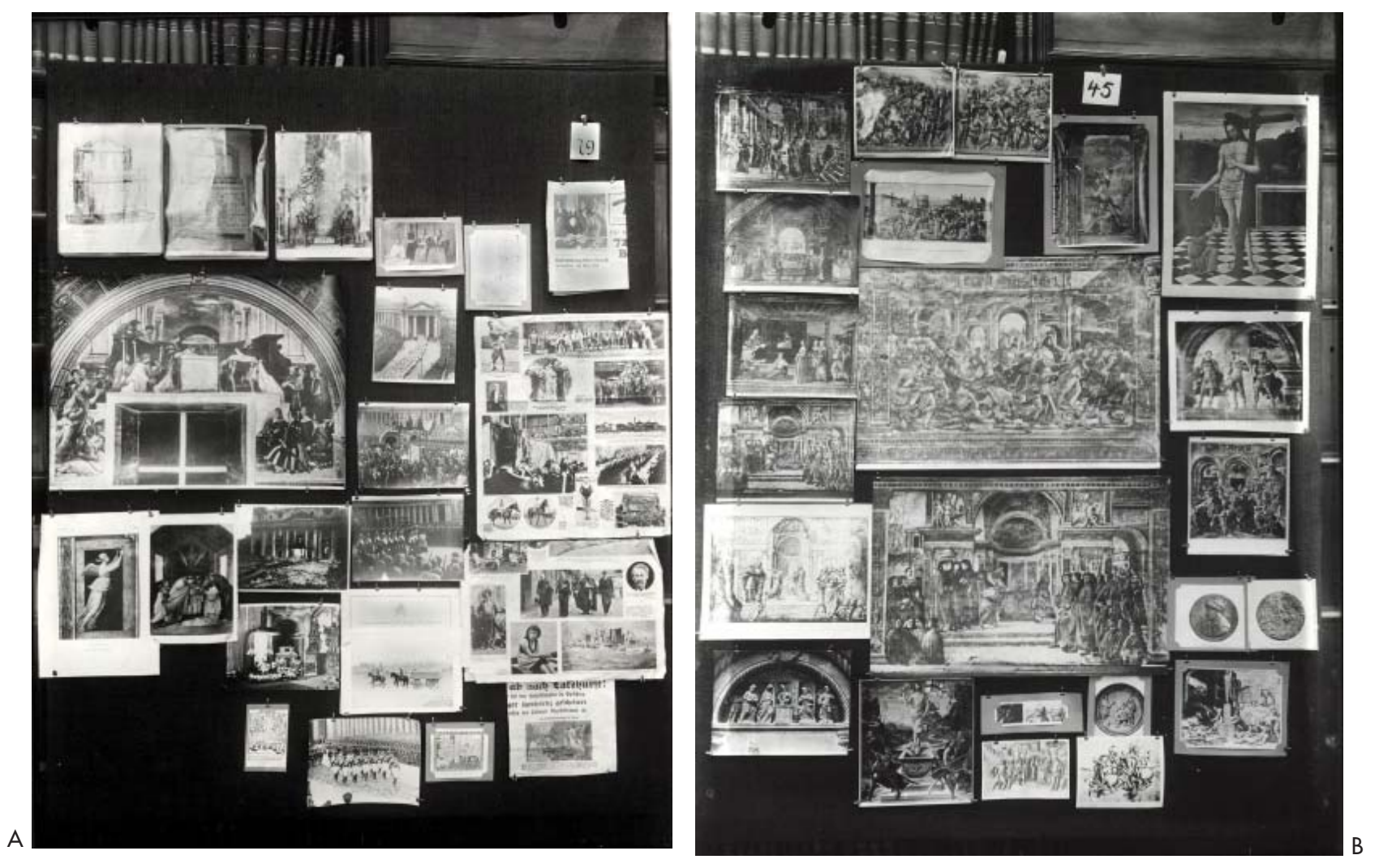


\subsection{LA PLASTIC FURNITURE COMO ESTADO DE ENCUENTRO}

A. Aby Warburg. Atlas Mnemosyne. Plancha 42 (1929).

B. Aby Warburg. Atlas Mnemosyne. Plancha 45, (1929).
55. Didi-Huberman, 2010: 20

56. Ibid.: 15

57. Nicolas Bourriaud en su libro L'esthétique relationnelle define el arte como un estado de encuentro. Tomamos prestado esta expresión para definir el mismo acontecer en las agrupaciones heterogéneas aunque con ello no queremos inferir que cualquier agrupación heterogénea sea una obra de arte. Veáse Bourriaud, 2006: 17
Didi-Huberman escribe, refiriéndose al atlas Mnemosyne de Aby Warburg, que este "delega en el montaje la capacidad de producir, mediante encuentros de imágenes, un conocimiento dialéctico de la cultura occidental, esa tragedia siempre renovada -sin síntesis, por tanto-.." ${ }^{55} \mathrm{Al}$ leer estas palabras no podemos dejar de reconocer en ellas los mismos comportamientos que los del objeto que venimos estudiando. No es tan extraño. ¿o es acaso un Atlas una agrupación heterogénea? ¿No podrían compartir el mismo funcionamiento?

El Atlas de Warburg era una colección de imágenes, un artefacto diseñado para hacer saltar correspondencias y para evocar analogías entre las representaciones del arte y las culturas de la humanidad. Un espacio para la interpretación del mundo. Dice Didi-Huberman:

"Así pues, de entrada, el atlas hace saltar los marcos. Quiebra las autoproclamadas certezas de la ciencia segura de sus verdades y del arte seguro de sus criterios. Inventa, entre todo ello, zonas intersticiales de exploración, intervalos heurísticos. Ignora deliberadamente los axiomas definitivos. $\mathrm{Y}$ es que responde a una teoría del conocimiento expuesta al peligro de lo sensible y a una estética al peligro de la disparidad. Por su propia exuberancia, deconstruye los ideales de unicidad, de especificidad, de pureza, de conocimiento integral. ${ }^{, 56}$

La plastic chair, al igual que el Atlas, inaugura un tiempo obstinado. Al carecer de las certezas de lo homogéneo está condenada a ser continuamente revisitada, para repasar sus diferencias o para buscar lo análogo. Se trata de una herramienta, no del agotamiento lógico de las posibilidades dadas, sino de la inagotable apertura a los posibles no dados aún. Las agrupaciones heterogéneas son, por la lógica del montaje con la que han sido construidas, una duración. O por decirlo de otra forma, un estado de encuentro ${ }^{57}$.

Este encuentro abre, como dice Didi-Huberman, una conversación. Un ir y venir entre las partes de la silla. Quizá deberíamos decir muchas 


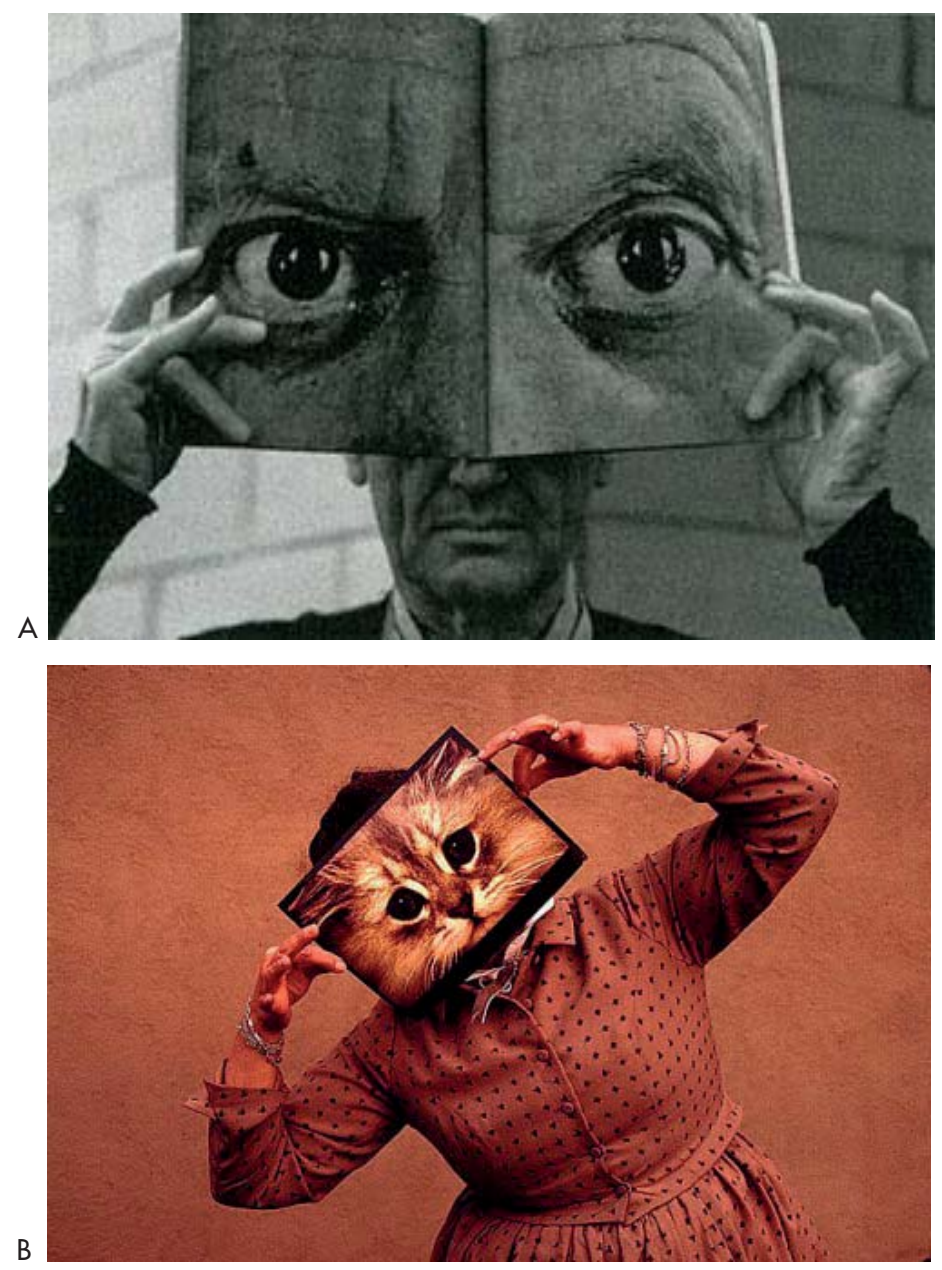


A. Charles Eames sosteniendo una fotografía de los ojos de Picasso, años 60.

B. Ray Eames sosteniendo una imagen de un gato años 60 .
58. "Percibir una imagen es participar en la formación de un proceso; es un acto creativo" Kepes, 1944: 15 conversaciones. Porque en realidad, si atendemos a las repercusiones materiales, sociales, constructivas o culturales que emergen de su aplicación, descubriremos que se solapa más de un dialogo. La plastic furniture sería un estado de encuentro por doble partida. Primero al convocar a las dos partes en un mismo cuerpo, y segundo, porque son muchas las conversaciones que se dan a la vez.

A través de rastros, testimonios o conexiones intelectuales se han reconstruido cinco temas de conversación. Para poder describirlas las hemos imaginado en dimensiones diferentes, ocurriendo a la vez, todas conducidas por los mismos participantes: el asiento y su base. Aunque algunas de estas dimensiones comparten regiones y tienen solapes, tienen suficiente identidad como para ser reconocidas como diferentes, la elección de las cinco nos permite abarcar aspectos seminales de la silla. La enumeración no sigue criterios temporales o de importancia, todas se dan a la vez y todas son relevantes para entender su complejidad. Tampoco quiere decir que sean las únicas. Simplemente se han considerado suficientes para demostrar nuestra afirmación. La exposición y enumeración ha seguido un criterio discursivo para facilitar su comprensión. Las cinco son apuestas de esta investigación y aunque todas ellas arrancan y se justifican en miradas, datos e historiografías previas, es la primera vez que se formulan como tales. Han recibido esta designación: la dimensión formal, la dimensión pública, la dimensión performativa, la dimensión relacional y la dimensión mestiza.

\subsubsection{Dimensión experiencial: la percepción dinámica del objeto}

"To perceive an image is to participate in a forming process; it is a creative act" escribía Gyorgy Kepes en la primera página de Language of Vision. ${ }^{58}$ Para él, la experiencia visual era un proceso dinámico de integración. La recepción de la imagen evolucionaba a través de un proceso cerebral que se construía a través de la interacción de la información que llegaba desde los diferentes componentes de lo observado. Cada uno de los componentes habita un campo semántico. La superposición de todos los campos que participan de la imagen en cambio se produce bajo nuestra percepción. De ahí que reconstruir la imagen tenga una duración y sea un acto creativo. 


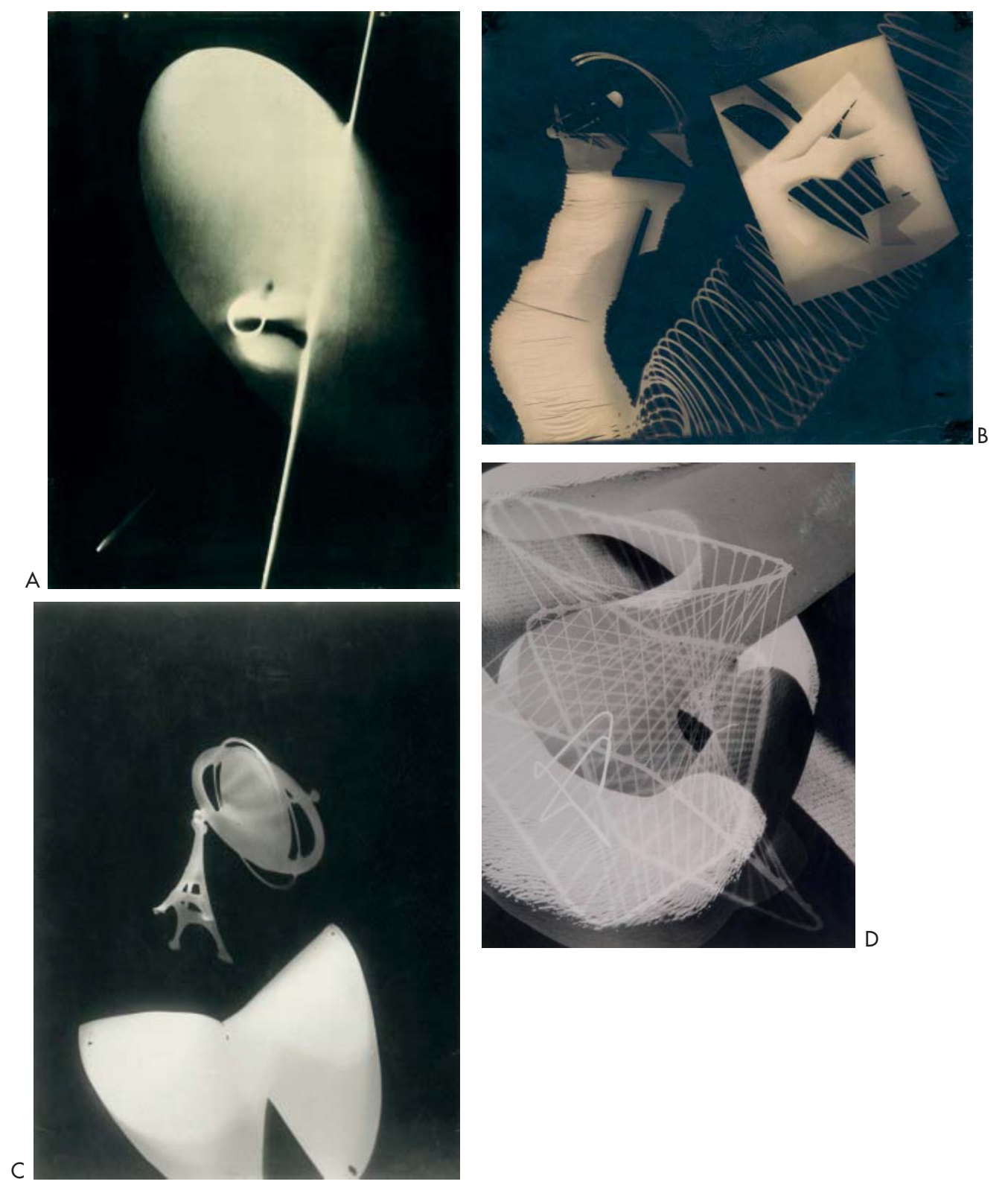


A. Moholy-Nagy. Photogram. Impresión sobre gelatina de plata (sobre 1923).

B. Moholy-Nagy. Photogram. Impresión sobre gelatina de plata (sobre 1925).

C. Moholy-Nagy. Photogram. Impresión sobre gelatina de plata (1928).

D. Eugene Bielawskiy Margaret Depatta(1940-41)
El mismo proceso tiene lugar en las plastic chair. La simultaneidad de lo diverso es reconocida por el ojo al saltar de una parte a otra de la silla. La retina -o podría también ser el tacto- registra la diferencia entre los cuerpos y estimula los procesos cerebrales de los sentidos. Se construye en ese ir y venir un ensamblaje arquitectónico. La familia de las sillas podría ser vista como una especie de bodegón contemporáneo en el que las texturas, la geometría y la materia se comparan y se exaltan. Son una excusa para reevaluar nuestra percepción de los objetos.

Moholy-Nagy señalaba que los fotomontajes demandan una gimnasia concentrada del ojo y el cerebro para acelerar la digestión visual e incrementar el rango de relaciones asociativas. ${ }^{59}$ Moholy-Nagy puso en práctica estás investigaciones en sus photograms. Aunque detrás de ellos estaba una investigación por la luz y su efecto al quedar retenida en el papel sensible, el resultado de las sugerentes formas combinadas es especialmente pertinente. Las superposiciones de objetos acoplados por la luz construyen imágenes de extraña ambigüedad y poética belleza. Aluden tanto a una forma de surrealismo - tiene algo de encuentro fortuito, esta vez en una mesa de luz $z^{60}$ - como a los primeros fotomontajes realizados por los artistas dada. Los objetos utilizados por Moholy-Nagy son reconocibles utensilios de cocina, partes del cuerpo y otros elementos delimitados ya sean figurativos o no. Todos ensamblados, en la ausencia de una cámara, por la simple exposición de un papel sensible a luz. Luz convertida en el ligamento que transforma la conjunción de realidades inconexas y dislocadas en una agrupación heterogénea. Algunos de los discípulos de Moholy-Nagy como Eugene Bielawski y Margaret Depatta utilizaron técnicas similares y llegaron a resultados que resultan sorprendentemente similares a la investigación formal de los Eames en las plastic chair. La imagen en la que las geometrías orgánicas se superponen a mallas alámbricas trianguladas es la de un retrato de un familiar cercano de las sillas.

La silla se materializa como una dualidad. Como un artefacto que es al mismo tiempo antagonismo y afinidad. Iñaki Ábalos ha descrito con precisión las fuerzas desplegadas en este tipo de dualismos arquitectónicos:

59. Moholy-Nagy, 1965: 212

60. "bello como el encuentro fortuito, sobre una mesa de disección, de una máquina de coser y un paraguas" decía del Surrealismo Isidore Lucien Ducasse, Conde de Lautréamont.
"Much historic architecture takes its compositive tension from two theoretically incompatible morphological organizations that 

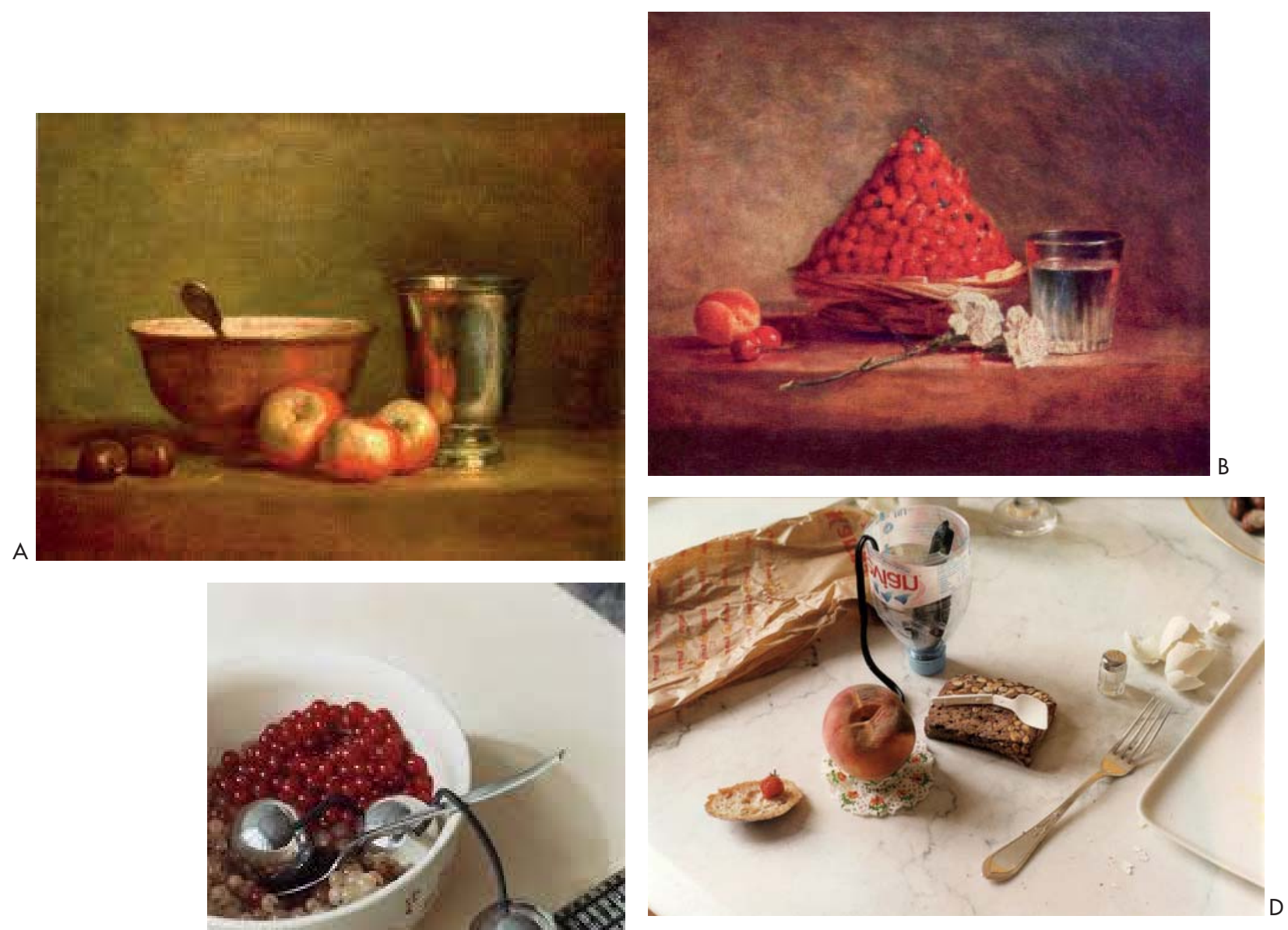
A. Jean Siméon Chardin. The Silver Goblet 1760 1768).

B. Jean Siméon Chardin. Le panier de fraises des bois.

C. Wolfgang Tillmans. Out of the Boxes (2004).

D. Wolfgang Tillmans. Sommer (2004). correspond to different universes or languages. This technique leads to a certain kind of monster or hybrid characterized by dualism. One of the basic monster assembly techniques involves the union of two organizations with one degree of compatibility and another obvious degree of incompatibility. Unions between different forms and materials can be carried out physically or by processes of chemical fusion. "Dualisms" may refer to limited scopes or can expand and infect all the scenarios affected by architecture, starting with its disciplinary definition, which is challenged by the view that the struggle between two disciplines is intrinsic to the project, or by incorporating a material, formal and geometric contradiction. Likewise, space can be conceived by introducing tension between the lower and the upper parts, or between interior and exterior, or by means of intrusions of varying depths and differing configurations." ${ }^{91}$

Esa tensión entre los cuerpos es la que detectamos cuando miramos el objeto. El ojo reconoce la simultaneidad de lo diverso al saltar de una parte a otra de la plastic chair. Registra la diferencia entre la translucidez texturizada de la fibra de vidrio y el brillo opaco de las bases; entre las curvas sinuosas del asiento y las tersas líneas que lo soportan; entre el profundo color en masa y la levedad espejada de las patas. Una estrategia cuidadosamente orquestada para excitar la percepción del observador. La retina registra y estimula los procesos cerebrales de los sentidos. De alguna forma nos sentimos cercanos a esos ejemplos de las alegorías que ya había mencionado Kepes. La familia de las sillas no deja de ser una especie de bodegón contemporáneo en el que las texturas, la geometría y la materia se comparan y se exaltan. Como en esas naturalezas muertas de Pieter Claesz, en el que nos balanceamos entre el brillo en el vidrio de la copa a la materia porosa de la cáscara del limón. Como en cualquier bodegón de Chardin en el que las sustancias adquieren viveza por su antagonismo. O en los más contemporáneos de Wolfgang Tillman en los que la fotografía nos devuelve la condición material del mundo y nosotros la seguimos, buscando comparaciones, en una migración perpetua de un objeto a otro, en un tiempo de divagaciones 

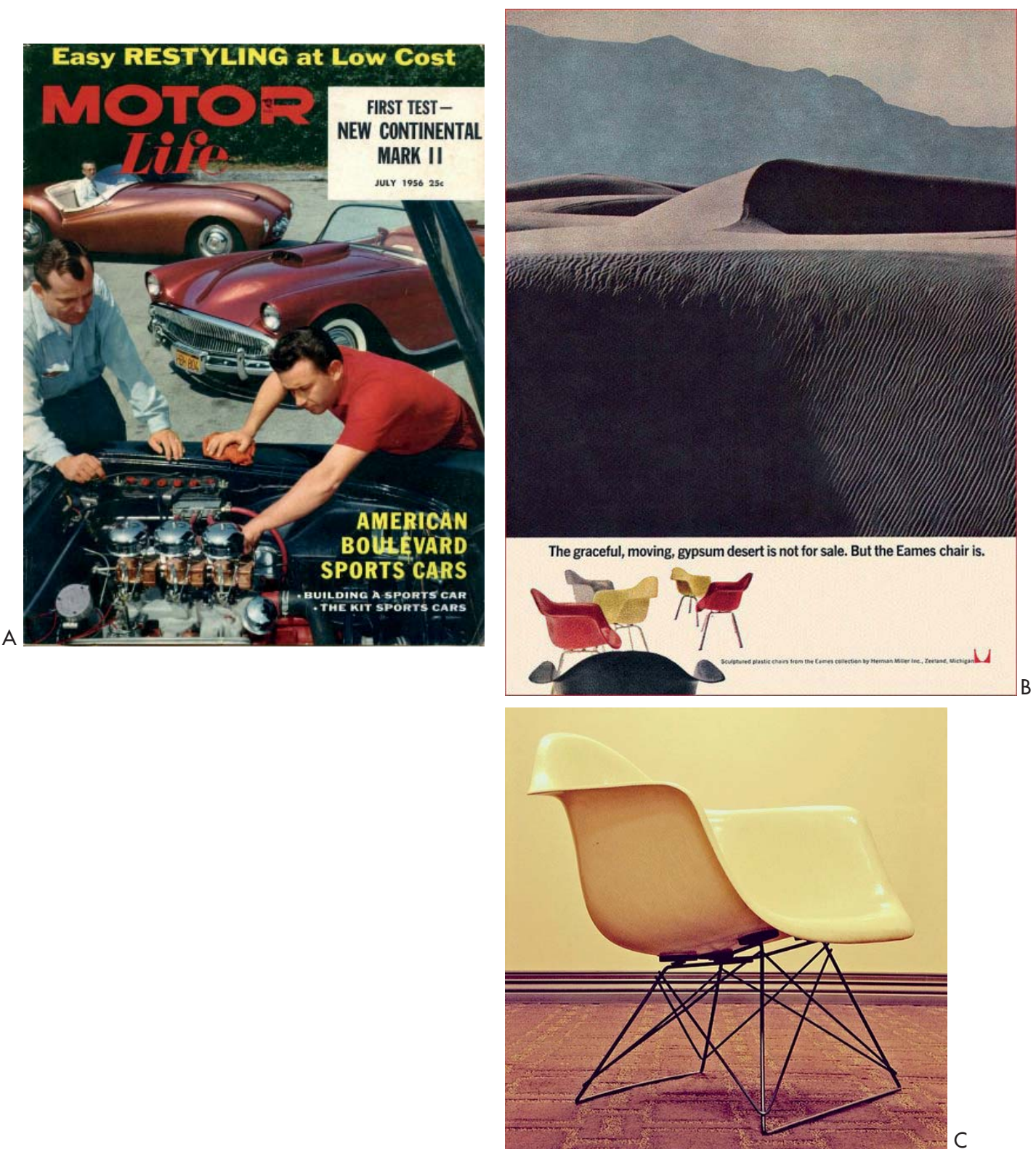
A. Portada de MOTOR Life, Julio 1956. American Boulevard Sport Cars.

B. Publicidad de las Fiberglass Shell Chairs. Con la descripción: The graceful, moving, gypsum desert is not for sale. But the Eames chair is.

C. Charles y Ray Eames. Fiberglass Shell Chais, LAR Model (1950).

\subsubsection{Dimensión pública: la espacialización de la seducción}

Según Kepes, las máquinas y los productos de las máquinas no podían ser entendidos simplemente por su imagen externa por lo que para su interpretación era necesario utilizar modos de expresión específicos. Precisamente por eso en el arte de los anuncios, que para él era equivalente a cualquier otro arte, la técnica del fotomontaje tenía una relevancia especial ya que no provenía de las formas tradicionales de representación. La imagen pura y fija de un hecho o una idea había dejado de ser suficiente para inducir respuestas fuertes en el espectador. Para que un mensaje fuera efectivo era necesario que el cliente experimentara visual y vitalmente la obra publicitaria.

La plastic furniture incorporaba en su materialización los mecanismos que había establecido Kepes para el arte de los anuncios: una mezcla de experiencia visual y vital. La silla, como hemos mencionado, era un objeto atractivo e inesperado, capaz de capturar el espíritu de su tiempo. La filosofía de Herman Miller, fabricantes de los muebles en aquella época, se mezclaba con la de los Eames en un lema común, "You're not making furniture any more, you're making a way of life- a life style." ${ }^{\prime 2}$ Para el estándar del mobiliario de aquel momento, sin duda era un artefacto extraño y llamativo que se parecía más a las evocadoras formas de un coche o a los nuevos electrodomésticos que al mobiliario pesado de madera al que estaban acostumbrados los hogares americanos. Su extrañeza no generaba rechazo sino que por el contrario creo una enorme expectación. La cobertura por parte de los medios impresos fue enorme y supuso una impagable publicidad gratuita. En Herman Miller fueron conscientes desde el principio de la enorme atención que despertaba su mobiliario moderno, de ahí que dieran total libertad a sus diseñadores para proponer nuevas creaciones. Sabían que cualquier novedad fuera de lo habitual recibiría una atención inmediata por parte de la prensa y la televisión. En la plastic chair la dualidad de los componentes aportaba precisamente esa diferencia, ese extrañamiento.

El diseño era, a pesar de su novedad, un evocador ejemplo de amabilidad. En una entrevista con Digby Diehl, Charles Eames recordaba una conversación con Eero Saarinen tratando especificamente esta cuestión: 

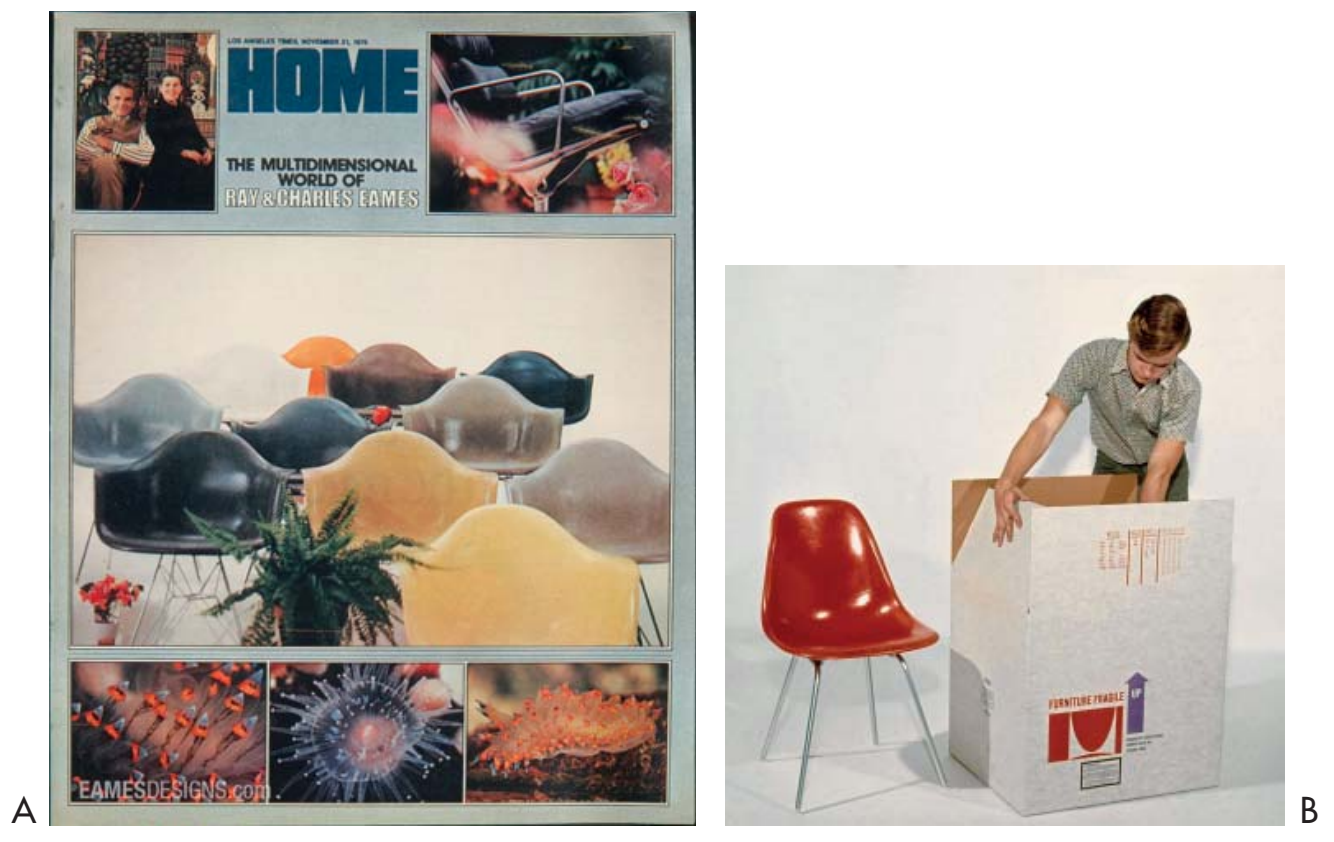
A. Portada de Los Angeles Times HOME Magazine. № 21, Noviembre de 1976. Variedad de colores de las Armchairs para ilustrar el "mundo muntidimensional" de Charles y Ray Eames.

B. Plastic Chair, y en su caja para embalaje, años 1950.
"Una de las cosas que reconocimos fue la cualidad de un anfitrión. Es decir, el rol del arquitecto, del diseñador, es el de un buen y atento anfitrión, cuyas energías están dedicadas a anticipar las necesidades de sus invitados -aquellos que entran en el edificio y utilizan los objetos en él. Decidimos que éste era un ingrediente esencial en el diseño de un edificio o de un objeto de uso". ${ }^{63}$

Ser un buen anfitrión quería decir ser el primero en establecer una conversación, involucrar al invitado y asegurar que se siente singular sin ser extraño. Es seducir sin violentar. Administrar una curiosidad que no despierta el pánico. Para participar de estas estrategias de seducción los Eames se valieron los hallazgos del arte contemporáneo y la publicidad. Entendieron la capacidad de extrañamiento como una primera forma de interpelar y establecer una comunicación.

Tan hábiles en la materialización como en las herramientas de comunicación los Eames establecieron un modelo de venta de producto que empezaba literalmente en sí mismo, en el producto. Ajenos todavía a esa moral contemporánea que pretende poner fronteras entre el arte y el universo comercial de los objetos, los Eames buscaron un modo de operar en la realidad publicitaria de la producción material. Dieron respuestas a las dudas del fabricante, del comprador y del usuario. De alguna forma, diseñaron el objeto que todos ellos estaban buscando. Desgranaron una a una las aspiraciones del comprador americano. Entendieron la importancia del coche y el electrodoméstico no como función sino también como representación, sintonizaron con las ansias de modernidad y con la necesidad de "electrificar" o vitalizar la vida con colores brillantes y con geometrías seductoras. Sin duda lo consiguieron materializar, no solo para su tiempo sino también para el nuestro. Hoy en día es un objeto de deseo, una pieza de coleccionista, un estándar de nuestra cultura, o una silla cualquiera que fácilmente muchos pueden reconocer.

\subsubsection{Dimensión performativa: la silla como proceso abierto}

Aunque las sillas eran y son admiradas por su condición de objeto, los Eames siempre destacaron su aspecto de work-in-progress. ${ }^{64}$ La silla era un artefacto 


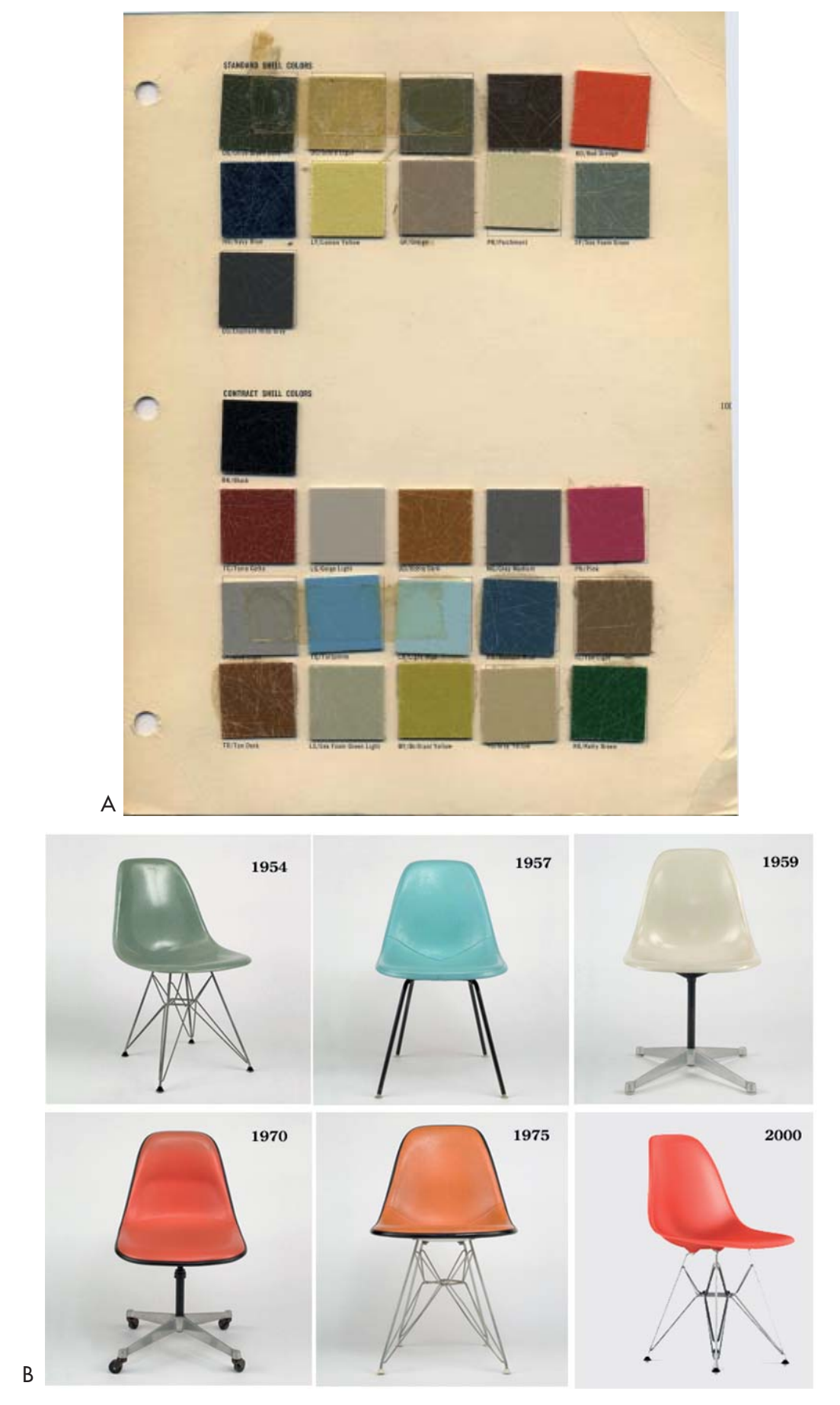


A. Página del catálogo de muestras de Herman Miller con las opciones de color de la fibra de vidrio, 1962.

B. Charles y Ray Eames. Modelos de Plastic Chair de 1954, 1957, 1959, 1970, 1975, 2000, producidos por Herman Miller
65. Albrecht, 1997: 24

66. Los asientos y las bases podían ser apilados de forma independiente para su transporte reduciendo los costes de envío de forma notable.

67. Zenith Plastic fue la empresa encargada de producir los asientos de las sillas durante los primeros años de producción. que posibilitaba la elección y personalización por parte del comprador basado en las propiedades de la técnica del montaje y la autoedición. El consumidor participaba activamente en el proceso de ensamblaje, adaptación y montaje de la silla. ${ }^{65}$ Lo que hoy se ha convertido en una estrategia habitual de mercadotecnia en aquel momento fue una sorprendente innovación. Las ventajas eran diversas, desde la capacidad de introducir variaciones al producto a su facilidad para la distribución. ${ }^{66} \mathrm{El}$ gran éxito comercial se debió a la capacidad para adaptarse a muy diversos mercados, desde las oficinas al espacio doméstico pasando por el institucional. Todos podían tener su silla. Esta versatilidad se debió fundamentalmente a su condición de agrupación heterogénea segregable en partes

En el caso del asiento las posibilidades de la resina de poliéster no solo permitieron la amable forma orgánica en la que descansar el cuerpo sino que también aportó lo que sin duda sería una de las mayores virtudes de la silla, la capacidad de elección de color. La meticulosidad con la que los Eames elegían los tonos fue una de las partes más intensas del proceso, lo que obligó, como recordaban los trabajadores de Zenith Plastics ${ }^{67}$, a hacer decenas de pruebas descartadas por Ray y Charles hasta llegar a los colores elegidos. Al principio optaron por solo tres colores neutrales para que funcionaran en diferentes situaciones, el parchement, un color que dejaba a la vista la translucidez de la fibra de vidrio, el greige, una especie de gris crema y el elephant hide gray, que era un gris cálido casi negro. Posteriormente, en 1952, se añadieron seis colores más: lemon yellow, sea foam green, bright red, dark blue, mustard y light grey. Con el tiempo el abanico de colores fue aumentando, y en 1963 la paleta llegó hasta los 16 colores. Pero el innovador sistema de bases intercambiables no fue menos importante para el éxito del producto. Las bases aportaban la mayor diversidad funcional. Permitían estar trabajando o relajado, sentado en línea con otros o balanceándote cómodamente. La conjunción de bases y asientos jugaba un papel fundamental en esta cualidad performativa. La silla no era un objeto sino un catálogo. La silla habitaba un tablero de posibilidades atravesado por las variables de la ergonomía, el uso y la decoración. De alguna forma renunciaba a ser única para ser cómplice de las voluntades de otros. La silla permitía al consumidor, con la elección de la base apropiada, ser adaptada a entornos diferentes, ya fuera en casa como en el espacio de trabajo, en el interior o en el exterior. Como apuntaban Allison y Peter Smithson: 

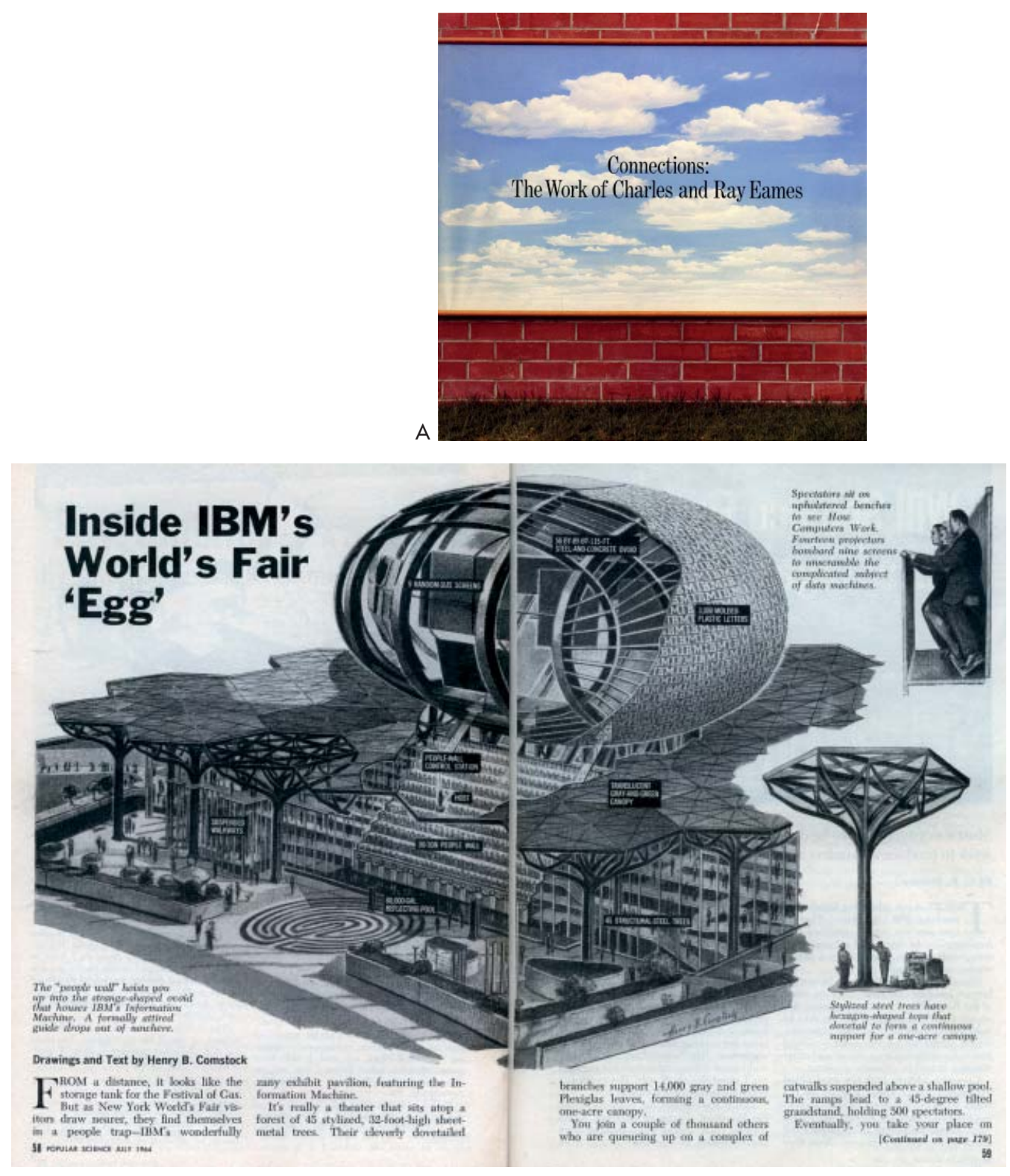
A. Portada del catálogo Connections: The Work of Charles and Ray Eames en la Frederick S. Wright Art Gallery (1974).

B. Charles y Ray Eames. Diagrama del pabellón que realizaron para IBM. Feria Internacional de Nueva York (1964).
68. Smithson y Smithson, 2001: 72

69. Lai, 1999: 11

70. Las charlas consistieron en 6 jornadas durante 1970 bajo el título común Problems Relating to Visual Communication and the Visual Environment.
"Las sillas de los Eames son las primeras sillas que se pueden colocar en cualquier posición en una habitación vacía......Las sillas pertenecen a sus ocupantes, no al edificio. No como las sillas de Mies, que eran sobre todo del edificio y no de los ocupantes." 68

Pero no solo deja de pertenecer al edificio sino que la silla se convierte en un objeto inteligente, capaz de trasmitir y alinearse con necesidades del usuario y con los valores americanos de la posguerra. La silla era una prolongación de la cultura americana y reunía todas las variables necesarias para encajar en el modelo productivo y comercial de su época: participaba de la diversidad de la oferta, de la libertad de elección y de la filosofía "háztelo tú mismo."

\subsubsection{Dimensión relacional: la confluencia de universos}

En el trabajo de los Eames subyace el deseo de promover una comunicación expandida basada en el poder de objetos e imágenes para ampliar la comprensión del mundo. Sus investigaciones están dirigidas a diseñar dispositivos que funcionan como entramados de conexiones con los que superar los discursos lineales y autónomos. ${ }^{69}$ Buscan alternativas para la comunicación que, como anticipaba Hayakawa en el prólogo a Language of Vision, dejasen de mirar a las cosas de forma atomizada para empezar a mostrar sus relaciones.

No es extraño que fuera ese precisamente el hilo que guiase a Charles Eames cuando, con motivo de las célebres Charles Eduard Norton Lectures ${ }^{70}$, revisitó el trabajo de décadas de la oficina. Con el título Problems Relating to Visual Communication and the Visual Environment la conferencia explicaba cómo durante su trabajo habían sentido la necesidad de inventar modelos visuales y espaciales para asuntos de interés práctico en los que se tendía a simplificar la comunicación. Ese era precisamente el caso de la arquitectura que habitualmente se encontraba infrautilizada en su papel de intermediario entre las personas y su conocimiento del mundo.

Charles Eames hacía hincapié en esa cuestión en la conversación con Owen Gingerich hablando del pabellón que realizaron para IBM con motivo de la Feria Internacional de Nueva York de 1964: 

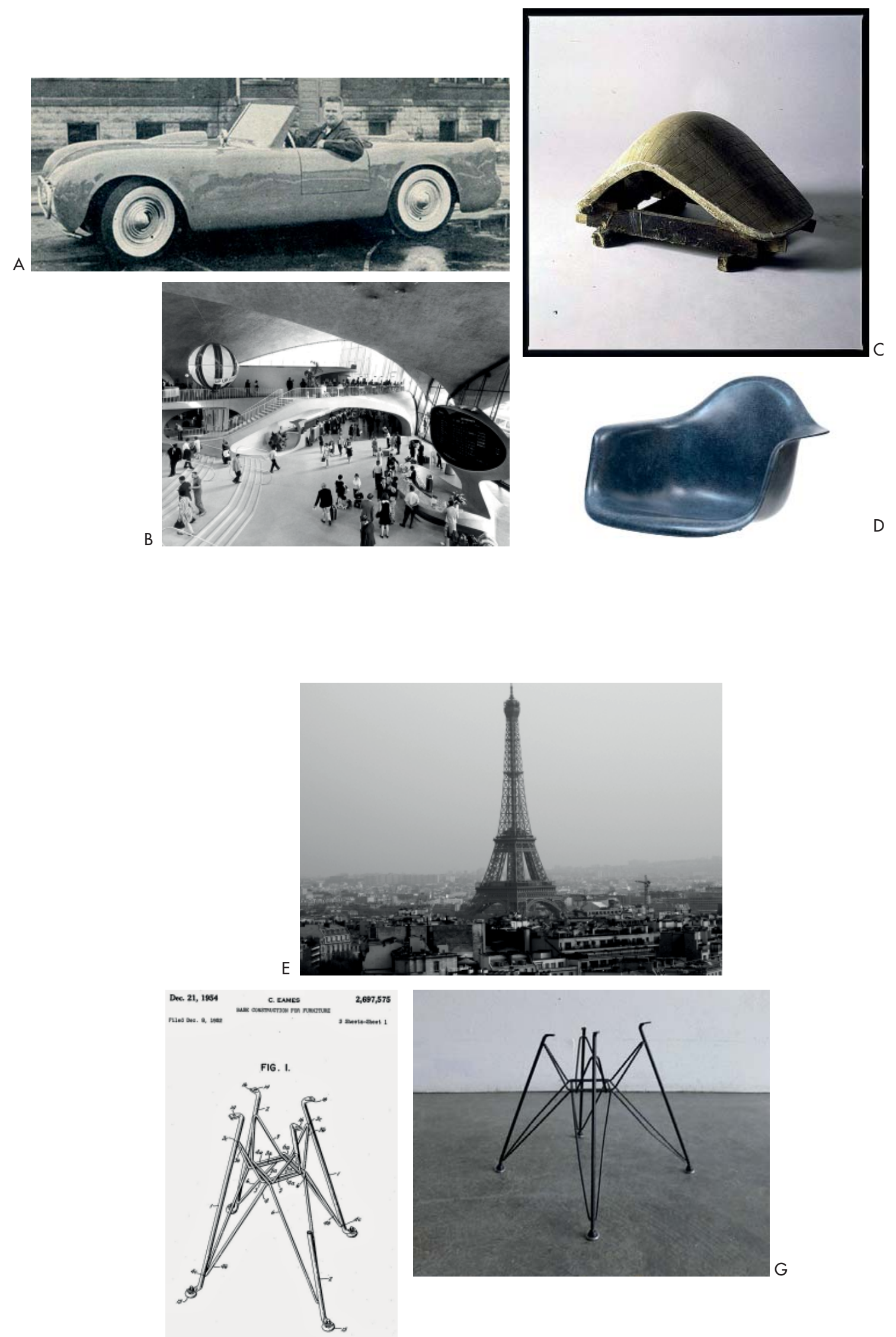

F

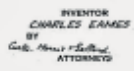


A. Coche deportivo, años 1950.

B. Eero Saarinen. TWA Terminal, Nueva York (1962).

C. Charles y Ray Eames. Estudio de cascarón, años 1950.

D. Charles y Ray Eames. Asiento de la Fiberglass Armchair, años 1950.

E. Torre Eiffel.

F. Charles y Ray Eames. Dibujo para la patente de la silla Eiffel Base Design aprobada en 1954 (1952).

G. Charles y Ray Eames. Estructura Eiffel Base años 50 .
71. Gingerich y Eames, 1977: 332-333

72. Esta cita pertenece al prólogo de la cuarta edición publicada en 1967. La traducción se ha tomado de Giedion, 2009
"In the IBM pavilion, for example, it was simultaneity. I think this is a very valuable device: to use multiple images to relate simultaneous happenings to the main theme. You get a feeling about relationships you didn't have previously. In thinking about decision making in the future -whether it be recombinant DNA or what have you- we believe some attention should be given to honing the techniques of showing critical thing simultaneously. We had hoped that by now this might be a rather general procedure. I still think it's a good idea." $" 71$

La plastic furniture es también un dispositivo con el que hacer visibles acontecimientos que quizá de otra forma hubieran pasado inadvertidas. Cuando los Eames eligen como nombre Eiffel base para una de sus soportes no solo lo hacen por un parecido formal sino también porque ella misma hace visibles unas lógicas estructurales que tiene en el monumento parisino una de sus mejores representantes. Su concepción y cálculo se basa en crear un modelo de elementos lineales por los que las fuerzas son conducidas como si fueran por tuberías. Por el contrario, el asiento de fibra de vidrio pertenece al mundo estructural de las membranas cuya aplicación está asociado a la aeronáutica y a los avances en la construcción en hormigón. La silla es un objeto didáctico en el que coexisten dos modos paradigmáticos de entender las estructuras. Sigfried Giedion en Space, Time and Architecture hacía referencia a esa doble concepción como uno de los cambios fundamentales de la arquitectura entre el siglo XIX y el siglo XX. La revolución se produce con el paso de unas estructuras canalizadas a través de elementos lineales en el siglo XIX a otro concepto estructural en el siglo XX que activa todas las partes del sistema según una distribución espacial de fuerzas y cuyo resultado es una membrana resistente (stressed-skin). Giedion alude a este cambio de paradigma también en las sillas: "Incluso el diseño de mobiliario sigue esta tendencia. Las sillas de una sola pata diseñadas por Eero Saarinen son puras construcciones laminares" 72

La duplicidad estructural, en su dimensión física, hace evidente la disparidad con la que se conduce la gravedad por el objeto, muestra dos planes con los que se puede gobernar la estabilidad de la materia. Pero también esa duplicidad es capaz de hacer resonar, en una dimensión temporal, dos imaginarios. Por un lado la membrana condensa todas las idealizaciones del 

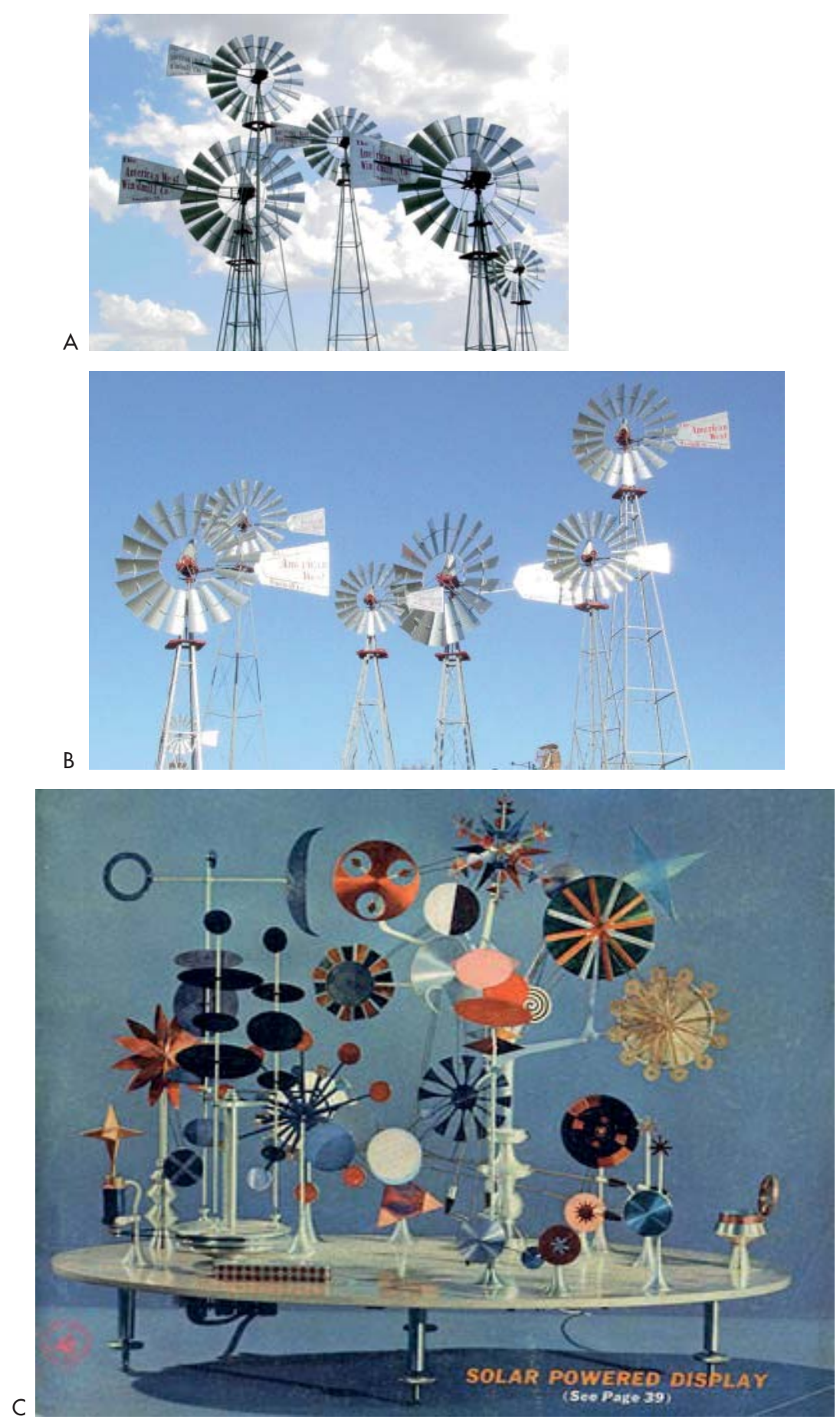
A-B. Molinos de viento utilizados para bombear agua. Principios de siglos XX.

C. Charles y Ray Eames. Solar Powered Display (1957). futuro y el progreso. Nos transporta, aunque solo sea desde un punto de vista infantil, a un mundo de naves espaciales, aviones, velocidad y fluidez. En cambio, la estructura de elementos lineales de la base aporta una mirada nostálgica ligada a la memoria y al pasado. Alison Smithson hacía la misma interpretación al vincular la estructura alámbrica de las patas con los molinos de viento utilizados para bombear agua:

"Durante la infancia de los Eames, estos mecanismos, con cientos de diseños patentados diferentes, se habían plantado por todo el paisaje de Estados Unidos. Parecía que incluso las sillas de alambre les debían a estas estructuras su confianza y su ascenso extraordinario." 73

Los Eames, como harían en muchas otras ocasiones, convierten a la silla en un estado de encuentro, un espacio en el que las partes muestran la diversidad con la que diseñamos el mundo. La coexistencia de ambas en un mismo cuerpo hace que esos orígenes diversos destaquen y se hagan comprensibles. Es en cierto modo un objeto pedagógico. Ya no estaríamos por lo tanto hablando de la construcción del objeto autónomo y autoreferencial de la modernidad, sino que se trataría de un ensamblaje construido por la acción compartida de múltiples agentes, en las que también otra vez como un estado de encuentro, aparecen el diseñador, el usuario y su contexto.

\subsubsection{Dimensión mestiza: la silla como conflicto}

Allison y Peter Smithson han apuntado que la estética de los Eames se construía a través de un cuidado criterio de selección de objetos que aportaba siempre una sorpresa “extra-cultural." La sorpresa a la que se referían tenía que ver con "una especie de maravilla asombrosa al poder mirar la disparidad cultural como un todo en feliz armonía. Esto suena algo extravagante pero el vehículo básico -el entramado de acero en el caso de la casa, la película y el modo de procesar el color en la obra gráfica, los prensados y los moldes en el caso de mobiliario- es algo cotidiano en el mundo de la cultura." ${ }^{74}$

Esta forma de pensamiento seguía la tradición iniciada por los artistas del movimiento moderno de incorporar a sus referentes muestras de otras 

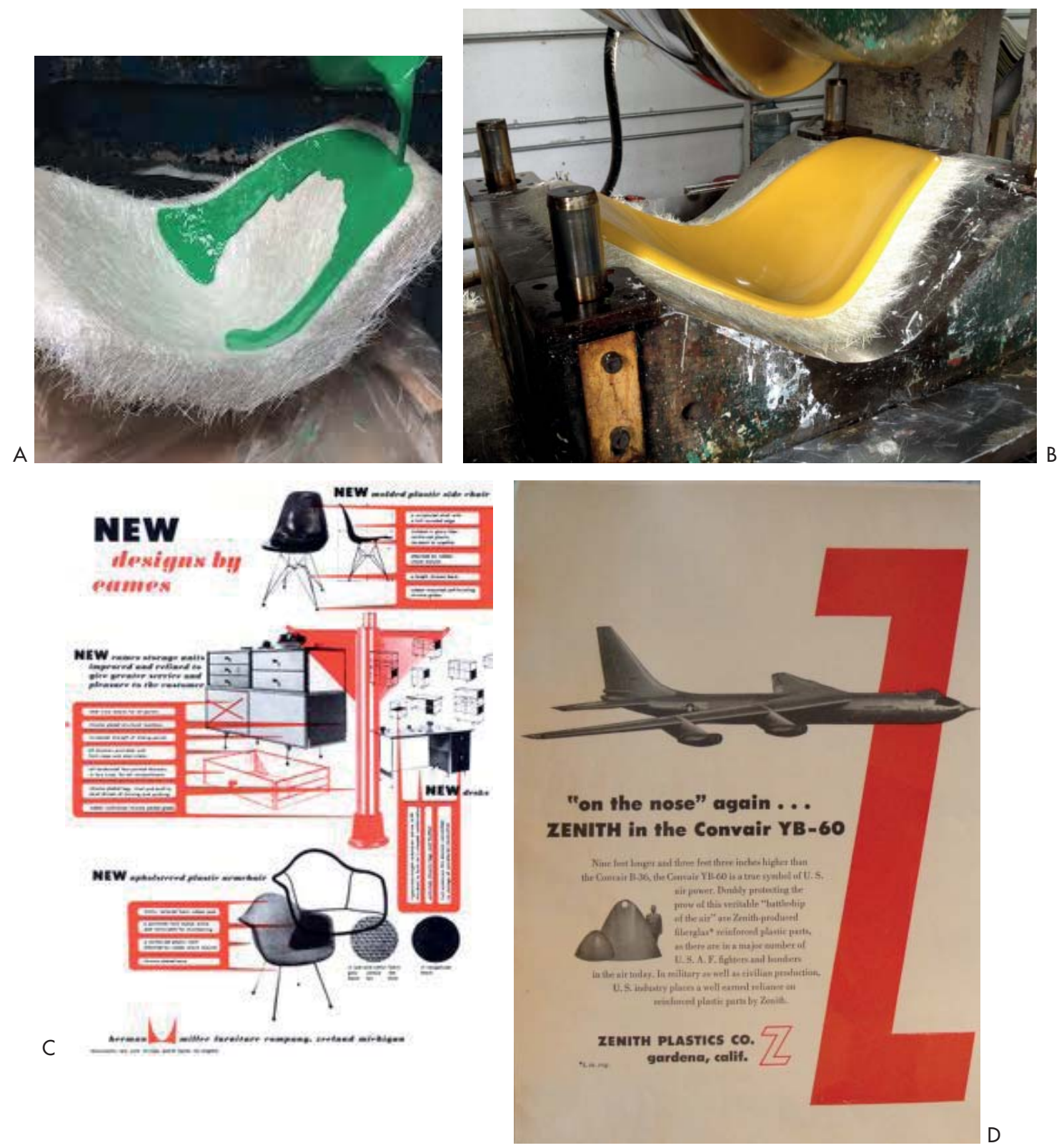
A-B. Charles y Ray Eames. D. Charles y Ray Eames. Proceso de vertido sobre fibra de vidrio para la producción del siento de la Fiberglass Chair, años 1950

C. Página de los diseños de Charles y Ray Eames, con la Eiffel Chair y la Armchair, años 1950

D. Anuncio de los componentes de plástico Zenith Plastics con el dibujo del Convair YB-60, años 1950.
75. House. After five years of living, es un video producido mediante el montaje de fotografías tomadas durante los cinco primeros años de habitar la casa. culturas. El interés de las vanguardias por las manifestaciones artísticas de áfrica o las nativas de américa contaminó también a los Eames como demuestra celebración de culturas en la que se convertiría el interior de su casa. Solo hace falta ver las imágenes de su salón para comprender esa fascinante conmemoración de lo diverso. Coleccionaron y dejaron que los objetos habitaran el mismo espacio, sin mediación y sin jerarquías. Son múltiples las imágenes que nos han quedado de la casa, y son muchas las referencias que se han hecho a lo que dentro de ella se guardaba. Es difícil separar la experiencia de la casa de los objetos que contiene, estos la construyen tanto como su estructura, sus cerramientos o su ubicación. Los propios Eames realizaron una película ${ }^{75}$ en la que relataban sus cinco años de vida en la casa con una secuencia de imágenes. Allí objetos propios y ajenos invocaban sus propias raíces y establecían un baile de equivalencias y multiplicidad. Cientos de objetos equiparados y enlazados por una forma de ver y por una técnica de asociación en el que las jerarquías tradicionales se borran para dejar aflorar otros mestizajes.

Quizá desde una perspectiva más reciente, lo que los Smithson describían como un todo en feliz armonía también se pueda leer como un todo en el que afloran los conflictos culturales. Las imágenes de la casa de los Eames hablan de la belleza de los objetos, de lo que tienen en común como manifestación humana. Obras traídas de todo el mundo que comparten símbolos, motivos, o tradiciones de ornamentación. Pero esas imágenes de la casa también hablan de los conflictos interculturales que emergen de la colonización, del desenraizamiento de las obras o de la descontextualización que implica el coleccionismo. La hibridación cultural crea un marco estético polémico desde el que la confluencia de objetos no puede solo ser vista como un final feliz sino como un estado de encuentro no resuelto.

La silla, como agrupación, tampoco está exenta de las controversias del tiempo que habita o de los que ha habitado. La plastic chair, como hemos visto estaba constituida por dos mundos: el del asiento, que aludía a un futuro, y el soporte, que enlazaba con el pasado. La cascara de plástico utilizaba la base para reafirmar sus magníficas cualidades: ligereza, resistencia, suavidad, temperatura, etc. Sin embargo, con el tiempo, el optimismo que despertaba la fibra de vidrio sufrió un desengaño. A finales de 1980 era sabido que la fibra de vidrio reforzada de la silla original tenía un efecto perjudicial 

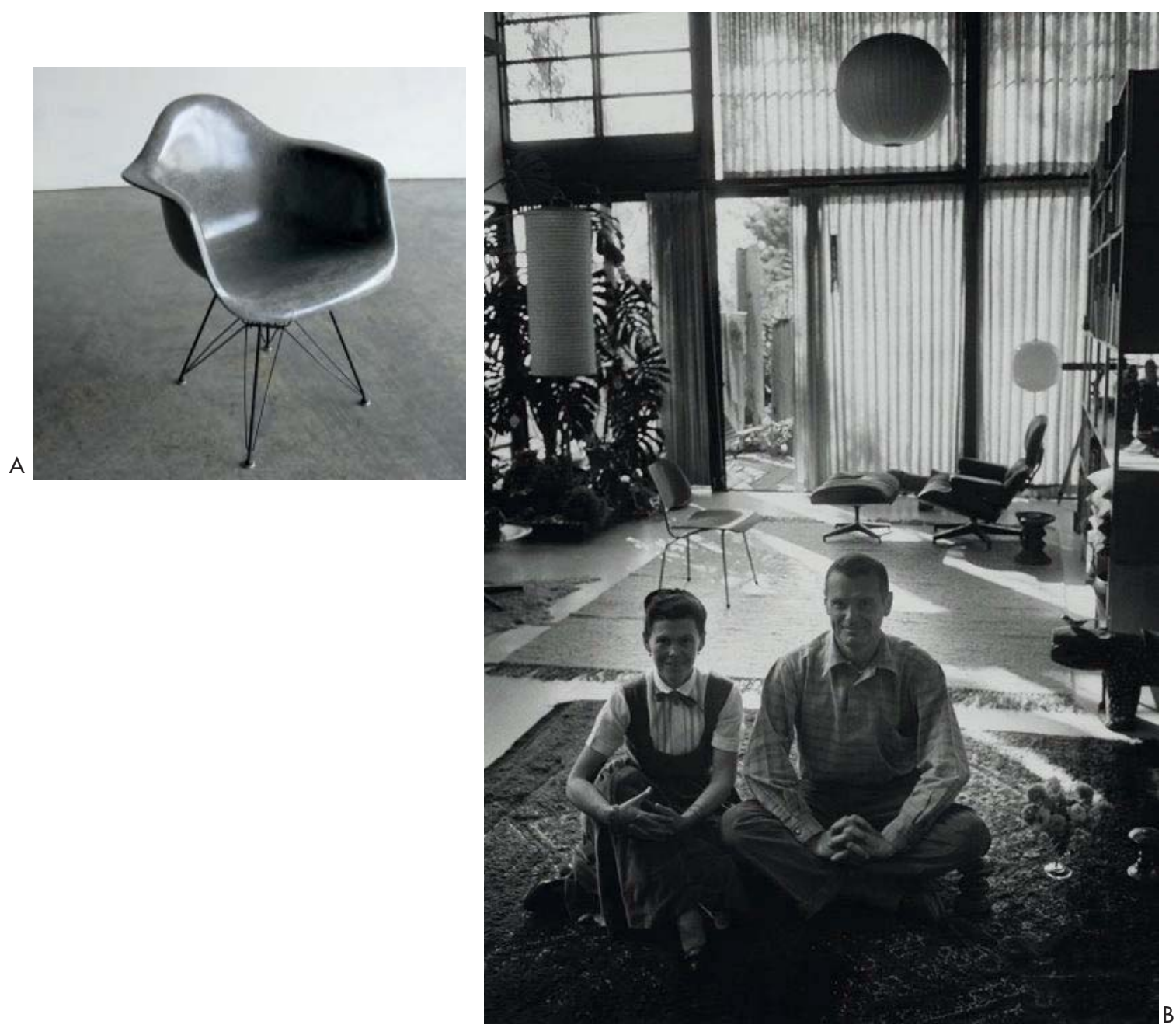
A-B. Charles y Ray Eames. Case Study House $n \cong 8$ (1945-49). Imágenes desde el interior. sobre el medio ambiente tanto en su proceso de fabricación como en su vida posterior una vez desechada. La agresividad de los materiales químicos utilizados en el proceso añadido a la imposibilidad de reciclar la fibra de vidrio llevaron al fabricante Herman Miller, tras consultar a Ray Eames, a suspender finalmente su producción en 1989. Hoy en día se ha vuelto a fabricar utilizando como alternativa el polipropileno.

La silla es, vista desde esta perspectiva, un ejemplo de los conflictos que emergen en los espacios del mestizaje. La acumulación y diversidad es una forma de hacer visible la condición compleja del mundo. Esos lugares abren estructuras para la interpretación y participación activa de los que se encuentran cerca promovidas por la fascinación y la capacidad de realizar conexiones por uno mismo. En definitiva ayudan a conectar, desjerarquizar e hibridar la visión del mundo para establecer una poética de la coexistencia. 



\section{CAPÍTULO 2. INTERVENCIÓN EN ARQUITECTURAS EXISTENTES: PLUS DE DRUOT, LACATON \& VASSAL}




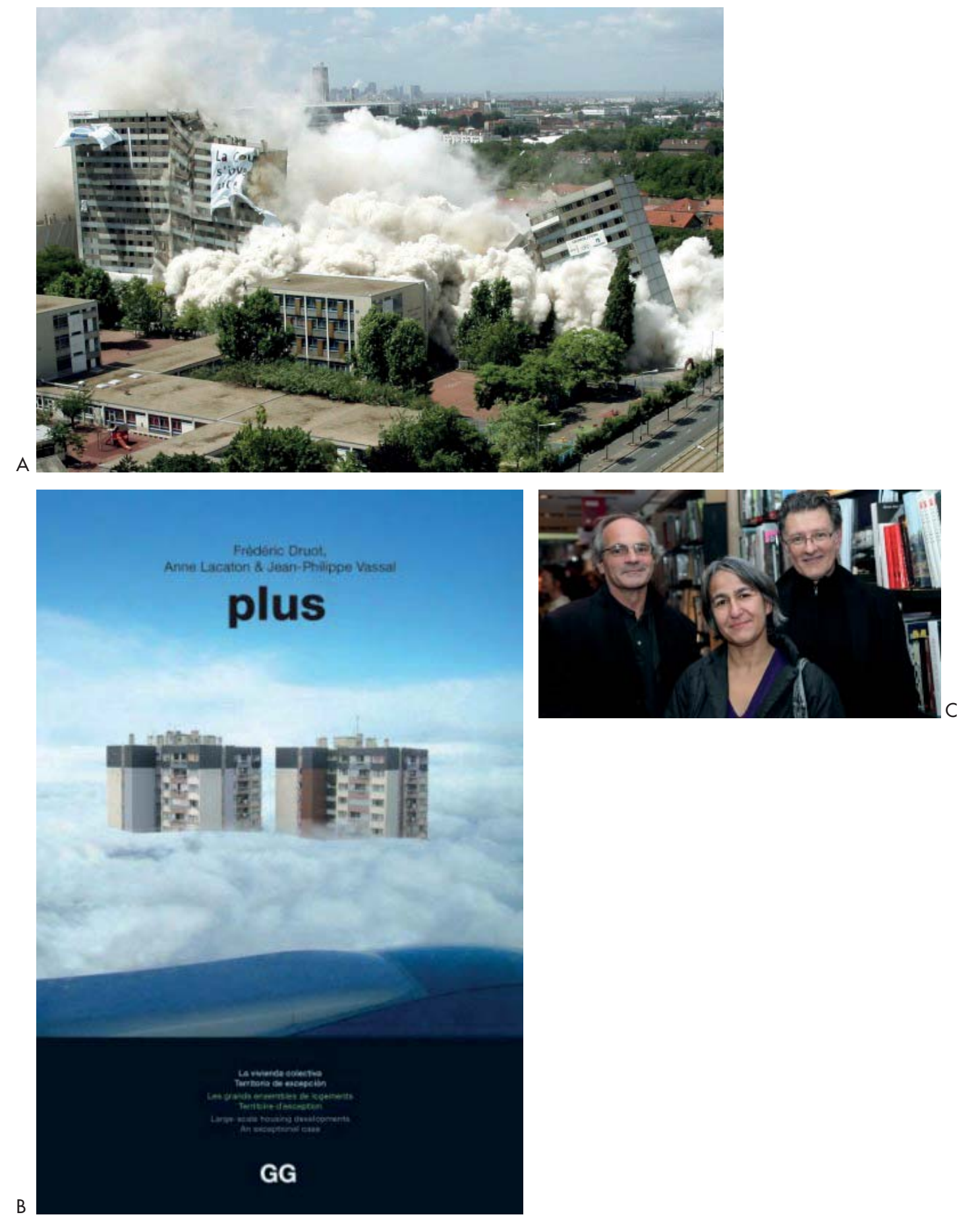


A. La Cité les 4000, La Courneuve. Demolición.

B. Plus (2004). Frederic Druot, Anne Lacaton y Jean-Philippe Vassal.

C. Frederic Druot, Anne Lacaton y Jean-Philippe Vassal.
No derribar nunca, no restar, ni remplazar nunca, sino añadir, transformar y utilizar

siempre.

Frédéric Druot, Anne Lacaton \& Jean-Philippe Vassal

\subsection{RESISTENCIAS}

"Doce años ya, quizá más, desde que comenzamos con Frédéric Druot, arquitecto y amigo. Desde hacía tiempo compartíamos intereses comunes acerca de la cualidad y el interés de las viviendas del periodo moderno, rechazadas todavía hoy en muchos sentidos. Cuando el gobierno francés decidió poner en marcha un programa de renovación urbana basado en la demolición de cerca de 200.000 viviendas de aquel periodo y su sustitución por otras nuevas, comenzamos el estudio porque estábamos convencidos del error que suponía demolerlas."’76

Ellos son Anne Lacaton y Jean-Philippe Vassal, y el estudio a la que se refiere está recogido en Plus, La vivienda colectiva-Territorio de Excepción ${ }^{77}$, una investigación manifiesto en el que se exponen propuestas de acción arquitectónica para revertir la obsolescencia de los conjuntos habitacionales franceses construidos en la segunda mitad del siglo XX. La investigación es una manera de demostrar que la obsolescencia que los políticos esgrimían para su demolición no era una obsolescencia funcional sino una de otro orden, una obsolescencia del entusiasmo que desvelaba un agotamiento colectivo y cultural consecuencia de un urbanismo segregador y de mínimos que había conseguido acabar con el optimismo moderno y emancipador con los que se habían diseñado. 

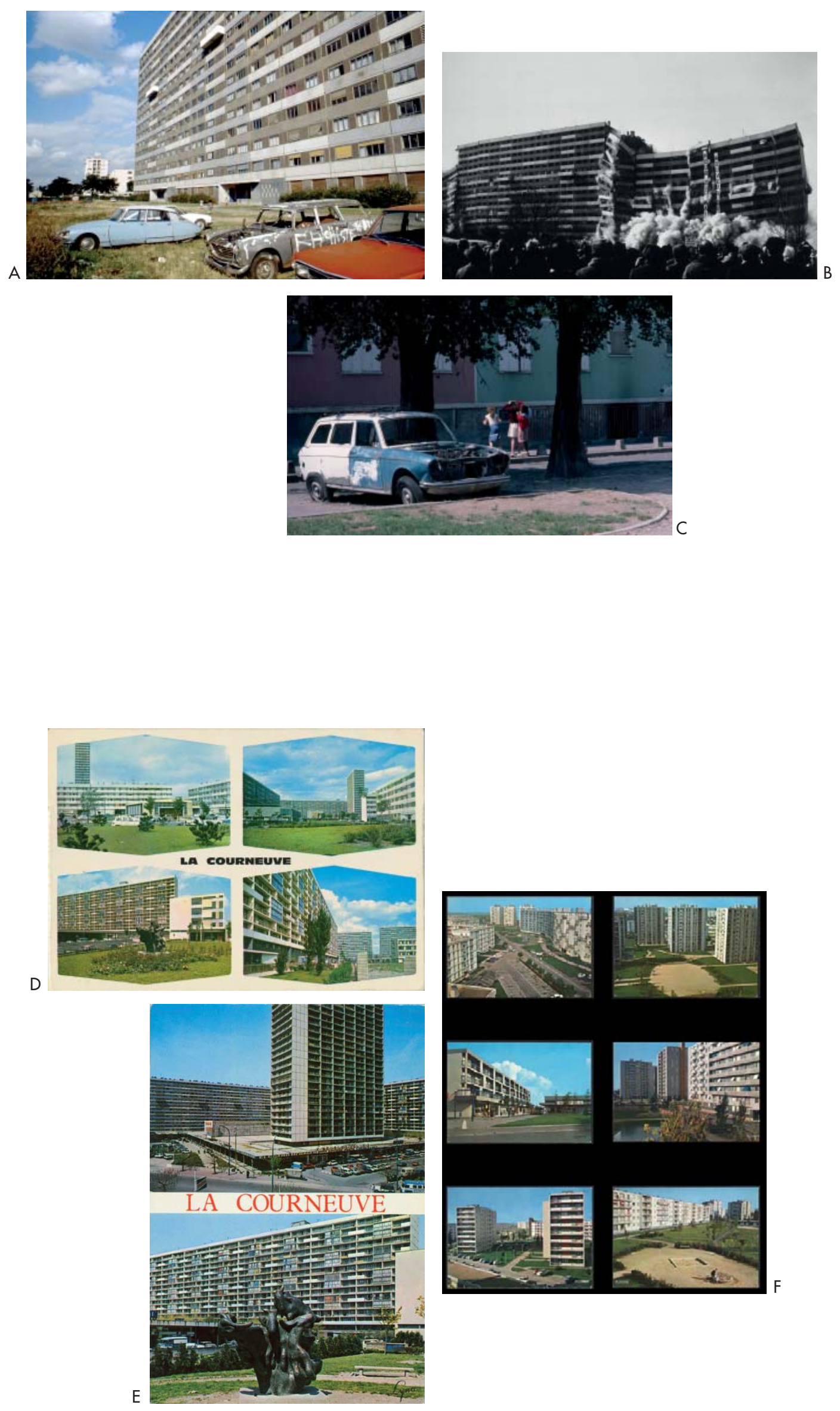
A. La Cité les 4000, La Courneuve, 1981

B. La Cité les 4000, La Courneuve. Demolición del edificio Debussi. 18 de febrero de 1986.

C. Bobigny, Cité de l'Abreuvoir del arquitecto Émile Aillaud. 1500 apartamentos. Octubre de 1984

D-E. Cartas postales de La Courneuve.

F. Cartas postales de Aulnay-sous-Bois, de izquierda a derecha, de abajo a arriba: Résidence Le Gros Saule et Savigny, Résidence Mille 1000 Résidence Le Gros Saule, Résidence des étangs, Résidence le Merisier.
Así lo recordaban:

"Cuando observamos esos bloques y torres construidos en los años sesenta en los suburbios, vimos sus posibilidades y no sus condiciones negativas. Vimos la capacidad del espacio para ser transformado, considerando la situación existente dentro de un contexto económico, pensando en la sostenibilidad y usando la menor cantidad de material posible. Al hacerlo de esta forma, la transformación puede llevar al edificio hacia un máximo de lujo, confort y placer, como alternativa positiva a la demolición y reconstrucción de nuevas viviendas. No es fácil convencer del potencial de esa transformación porque desde una perspectiva lejana cualquiera puede pensar que son sencillamente feas y que es imposible reconvertirlas en algo distinto. Pero desde su interior percibes la riqueza y el valor que cada familia -incluso en circunstancias de vida complicadas- aporta al edificio, con sus objetos personales, sus animales o su decoración. Hay una cierta riqueza vital en su interior que está lastrada, de alguna manera, por cómo es el edificio." ${ }^{78}$

Toda esa investigación es una forma de operar con lo existente para doblegar sus resistencias materiales y culturales. Es la construcción de una actitud hacia una materia que había perdido a casi todos sus defensores. Si el territorio de las arquitecturas ordinarias, como veremos más adelante, es el territorio de la anti-significación y de lo cuantitativo genérico, Druot, Lacaton \& Vassal encuentran en ese terreno de nadie -quizá por eso ellos lo subtitulan Territorio de excepción- un campo operativo a reivindicar. En definitiva, lo que proponen es una epojé de las categorías convencionalmente asumidas en la preservación para reformularlas y reescribirlas de forma creativa. Para entender la dimensión del hallazgo, es conveniente hacer un breve repaso a la noción histórica de la preservación y los cambios que ha traído el acelerado crecimiento urbano del último siglo en la conservación de lo existente. 

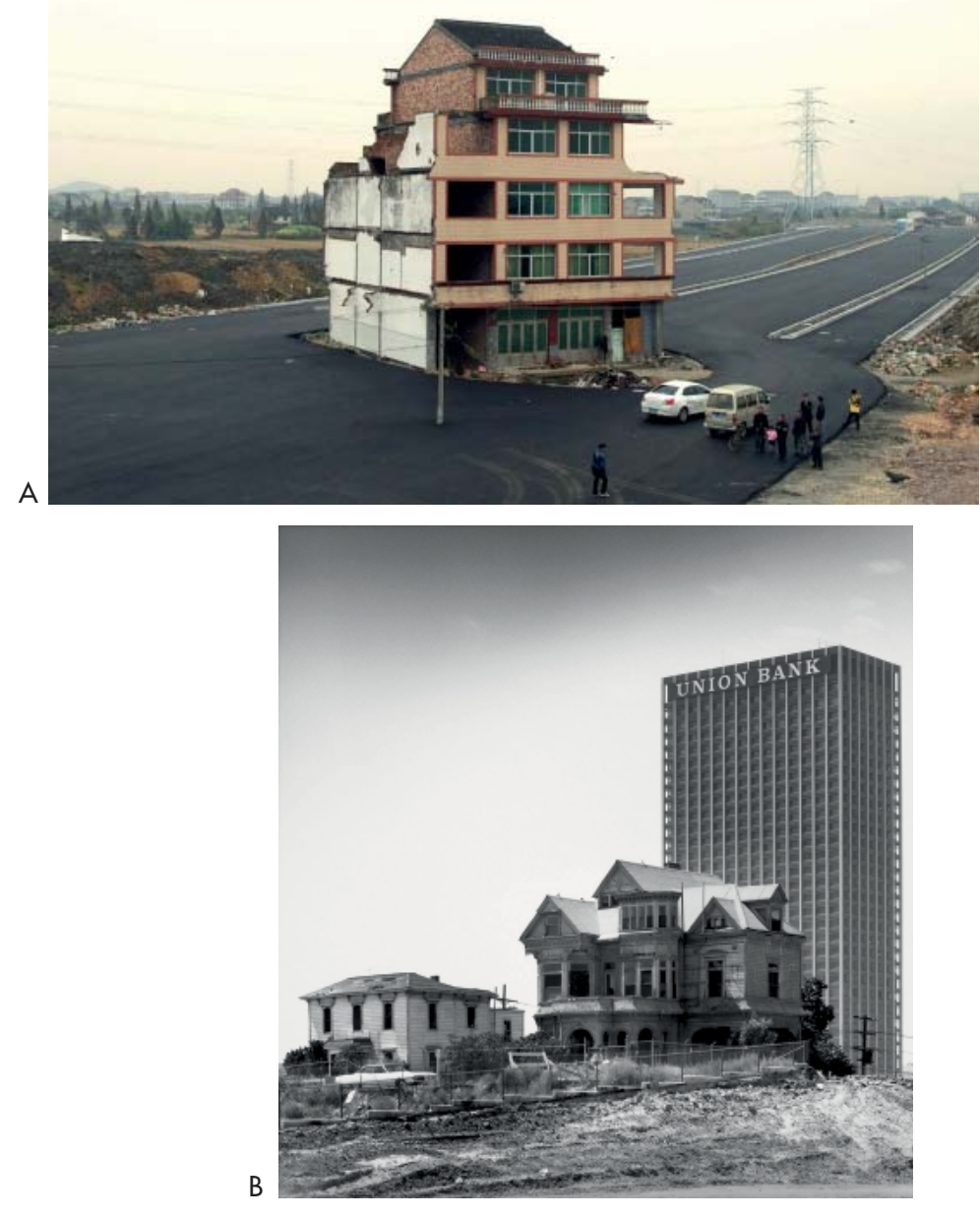


\subsection{RAZONES DE LA PRESERVACIÓN}

A. Resistencia en las ciudades chinas. Provincia de Zheijang en China.

B. The Castle, 325 S. Bunker Hill Avenue, Los Angeles, California. Demolido en 1969. Fotografía de Julius Shulman.
79. "Actualidad es cuando un faro está oscuro entre los destellos; es el instante entre el tic y el tac del reloj; es un intervalo vacío que se desliza para siempre a través del tiempo; la ruptura entre pasado y futuro; la interrupción en los polos de un campo magnético giratorio, infinitesimalmente pequeño pero en suma real. Es la pausa, entre el tic y el tac, cuando nada sucede. Es el vacío entre los acontecimientos" en Kubler, 1988: 219
Los objetos que habitan el presente son el resultado de la acumulación de tiempos diversos, su sedimento. Juntos definen una especie de naturaleza de la actualidad ${ }^{79}$. Construyen un tiempo en el que coexisten pasados y se proponen futuros. Sin embargo todo ese material vive bajo una misma condición, está marcado por la degradación. La consciencia de la erosión material y la posibilidad de la desaparición conlleva, a su vez, el surgimiento de su reverso: la noción de preservación. En la arquitectura, ante la inmensidad de lo construido y la imposibilidad de paralizar el desgaste de forma global, el acto de conservar y la elección de lo que es necesario proteger se vuelve trascendental: ¿Qué es aquello que hemos decidido, como sociedad, que debe perdurar y conservarse en el tiempo?, ¿qué preservamos; qué no?

Como construcción compartida, la condición de lo preservado ha cambiado a lo largo del tiempo y sigue siendo una arena de debates calientes y polarizados. La noción de la preservación se ha hecho cada vez más relevante y compleja, su campo de acción se ha extendido y sus motivos se han multiplicado. Las razones de la preservación son hoy en día más poliédricas y responden a intereses igual de diversos. La preservación histórica, cuyo objetivo era representar aspectos del pasado a través de la elección y conservación de los restos físicos ha dejado de ser la única sobre la que reflexionar. La preservación ha incorporado nuevas agendas: inversores buscando beneficios a través de la adaptación, defensores de lo comunitario intentando paralizar desarrollos especulativos, visiones desde la sostenibilidad que buscan reducir el consumo energético o ciudades en busca de atractores económicos y turísticos. Todos estos factores han hecho que hoy en día las razones de la preservación se solapen y sea difícil establecer los criterios de su aplicación. No es el objetivo de esta investigación hacer una lectura en profundidad de las razones de la preservación, pero sí, por el contrario, ver cómo estas han pasado de lo cualitativo a lo cuantitativo a la hora de poner en práctica sus programas de justificación. 

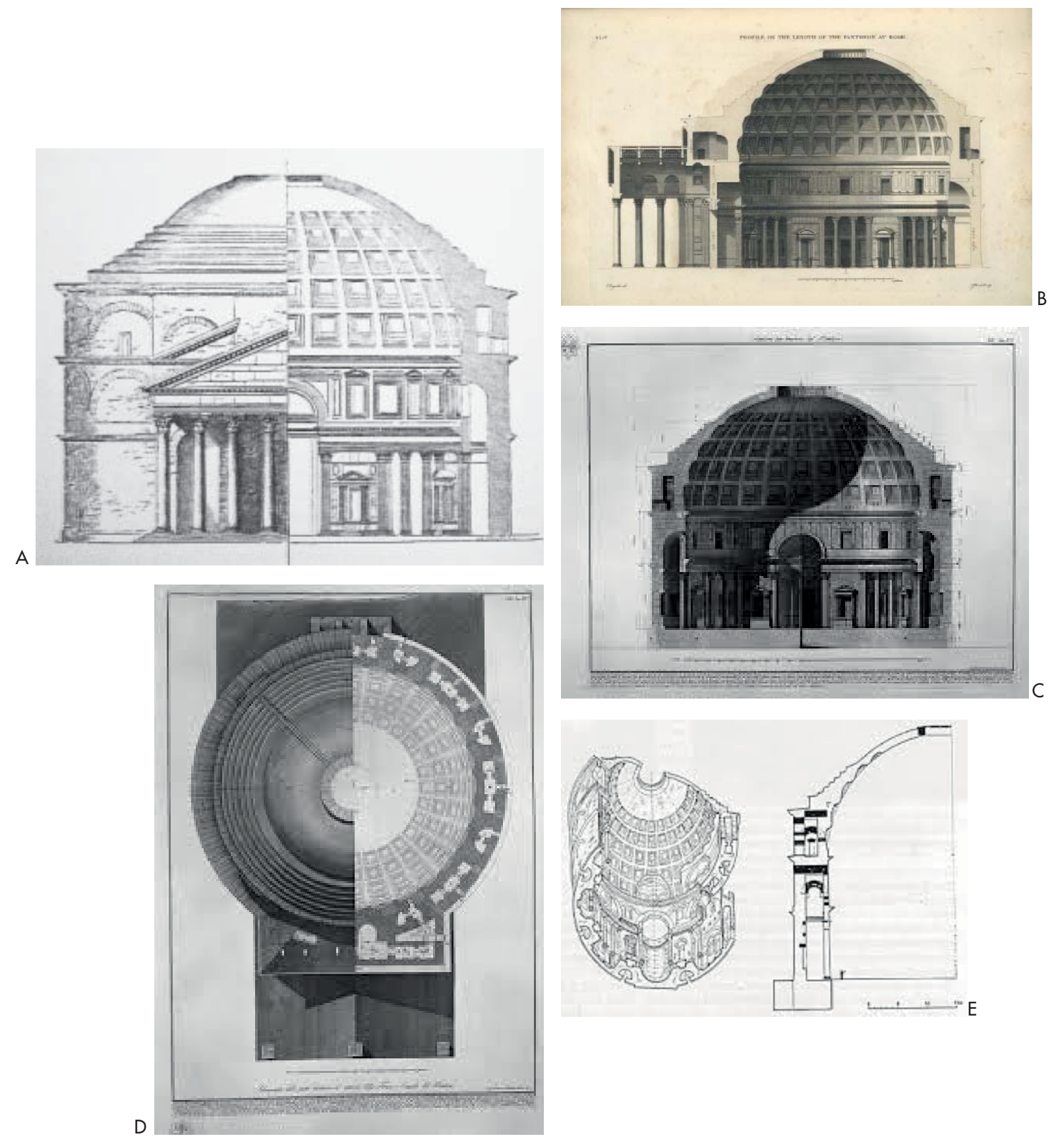
A-E. Imágenes del Panteón, Roma laño 118-125 d.C.).

80. Choay, 2007

81. Ibíd.: 12

\subsubsection{La aproximación cualitativa}

Si atendemos al estudio que ha realizado Françoise Choay, ${ }^{80}$ los inicios de la conservación se podrían situar en la Roma de principios del siglo XV. Numerosos testimonios dan cuenta del surgimiento de una mirada estetizante que, al posarse sobre los edificios, hizo de ellos objetos de reflexión y contemplación. Choay lo liga a la necesidad de crear, como individuos y sociedad, una memoria colectiva que permitiera superar el miedo al paso del tiempo. En sus propias palabras:

"La especificidad del monumento consiste entonces, precisamente, en su modo de acción sobre la memoria qué utiliza y moviliza por medio de la afectividad, para qué el recuerdo del pasado haga vibrar el diapasón del presente. Ese pasado invocado, convocado, en una suerte de hechizo, no es cualquiera: ha sido localizado y seleccionado por motivos vitales, en tanto qué puede contribuir directamente a mantener y preservar la identidad de una comunidad étnica, religiosa, nacional, tribal o familiar. El monumento es, tanto para quienes lo edifican como para los que reciben sus mensajes, una defensa contra los traumatismos de la existencia, un dispositivo de seguridad. El monumento asegura, da confianza, tranquiliza al conjurar el ser del tiempo. Garante de los orígenes, el monumento calma la inquietud qué genera la incertidumbre de los comienzos. Desafío a la entropía y a la acción disolvente que el tiempo ejerce sobre todas las cosas, naturales y artificiales, el monumento intenta apaciguar la angustia de la muerte y de la aniquilación.” 81

No será hasta el siglo XIX que las bases de los que hoy se conoce como patrimonio se establezcan bajo unos criterios de conservación que, si bien discutidos durante casi más de cien años, trabajaran por un mismo objetivo común. La presión de la ciudad moderna y una mirada romántica del pasado ensancharán sus límites y hará que sus intereses se amplíen también a lo edificado más próximo del quehacer humano. El monumento histórico adquirirá así una totalidad sin precedentes. El monumento tradicional, sin calificativo, encontrará presencia universal y al mismo tiempo hará revivir los pasados particulares de comunidades particulares. 

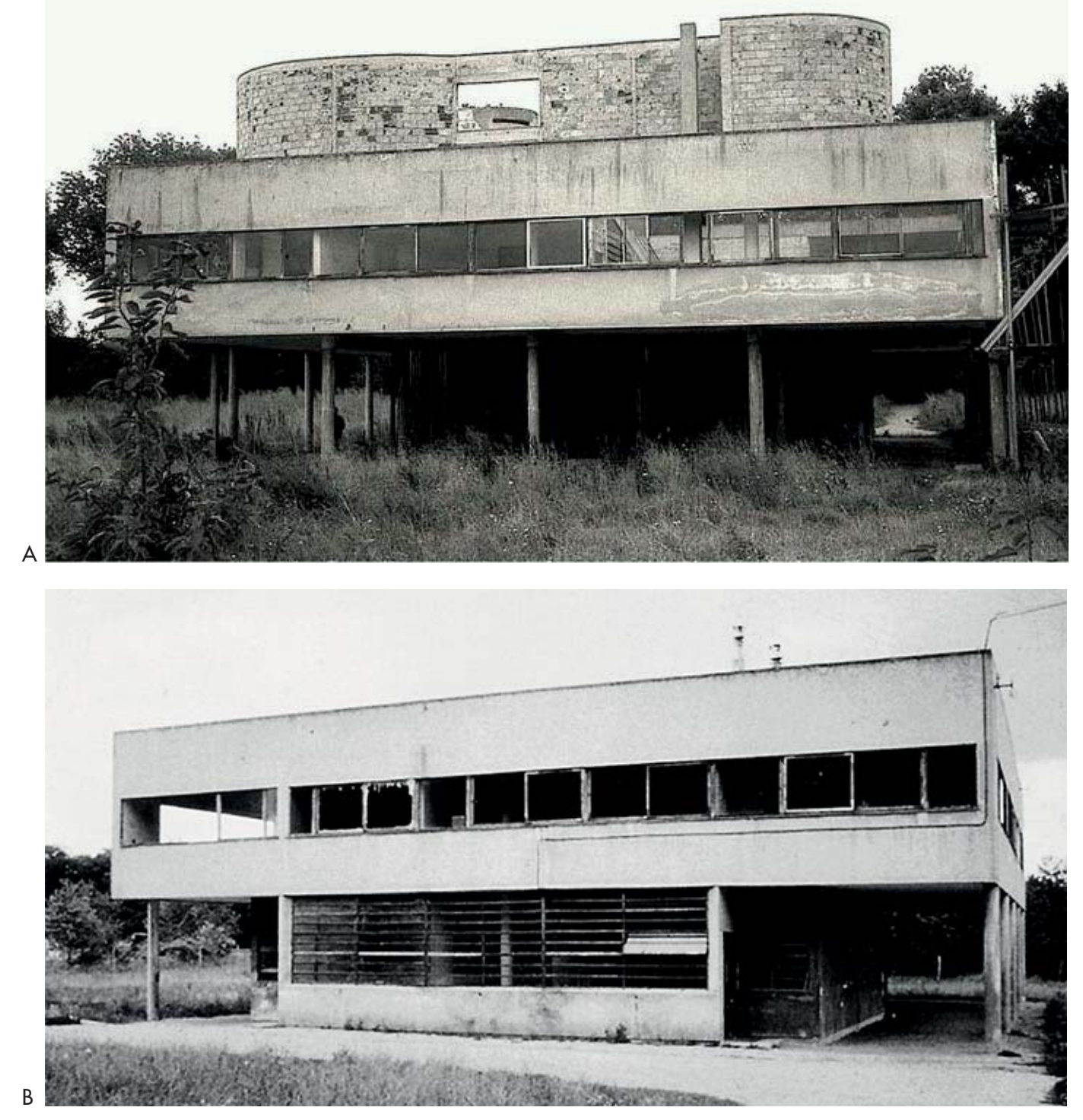
En el siglo XX la preservación redefinirá todos sus límites. El objetivo pasará a ser el de identificar, proteger, conservar, rehabilitar y trasmitir a las generaciones futuras el patrimonio cultural y natural. Los monumentos históricos constituirán solo una parte de la herencia a proteger, el legado se incrementará incesantemente por la anexión de nuevos tipos de bienes y por la disminución del tiempo que los separa del presente. El propósito de dicha práctica, leído hoy, ha sido sin duda un éxito. La proliferación y exhaustividad de los archivos de la cultura ha generado un catálogo extenso en el que las singularidades son puestas en valor. La capacidad de ampliación del inventariado y el abismo ante la posibilidad de la perdida ha multiplicado las incorporaciones al corpus de lo patrimonial. Las diferencias regionales, las particularidades estilísticas o los orgullos locales son alegatos comunes para justificar las nuevas anexiones. A este efecto hay que añadir también la ampliación del campo cronológico. A finales de los años cincuenta las fronteras temporales se desvanecieron. El criterio, considerado hasta entonces, de la Era Industrial como límite del archivo dejó de ser una referencia y su avance hacia el presente ha sido cada vez más rápido. Hoy en día contamos con ejemplos contemporáneos que en apenas diez años han pasado a formar parte de catálogos protegidos. Pero no solo se ha modificado el límite temporal, el patrimonio arquitectónico del SXX se ha incrementado con la incorporación del patrimonio industrial. Fábricas, graneros, silos han adquirido un estatus que a principios del siglo pasado se hubieran considerado impensables.

La genealogía de la preservación histórica o cultural se soporta en un andamiaje que los especialistas llaman "significación", una suma de atributos compartidos y estables que son visibles en su constitución material y que se pueden reconocer a través una mirada experta. Estos valores antes se consideraban fijos e inmutables, pero voces como las de Joseph Tainter y John Lucas ${ }^{82}$ han puesto de relieve que se trata de un concepto construido socialmente basado en valores tangibles e intangibles, sujetos a lecturas diversas y subjetivas que cambian a lo largo del tiempo. Y a su vez, en cierto modo opaco ya que, como ha indicado Randall Mason ${ }^{83}$ la idea de la "significación" es una caja negra, que por lo general solo es asignada y validada por los especialistas sin que exista un procedimiento ni una definición de los criterios que la otorgan. 

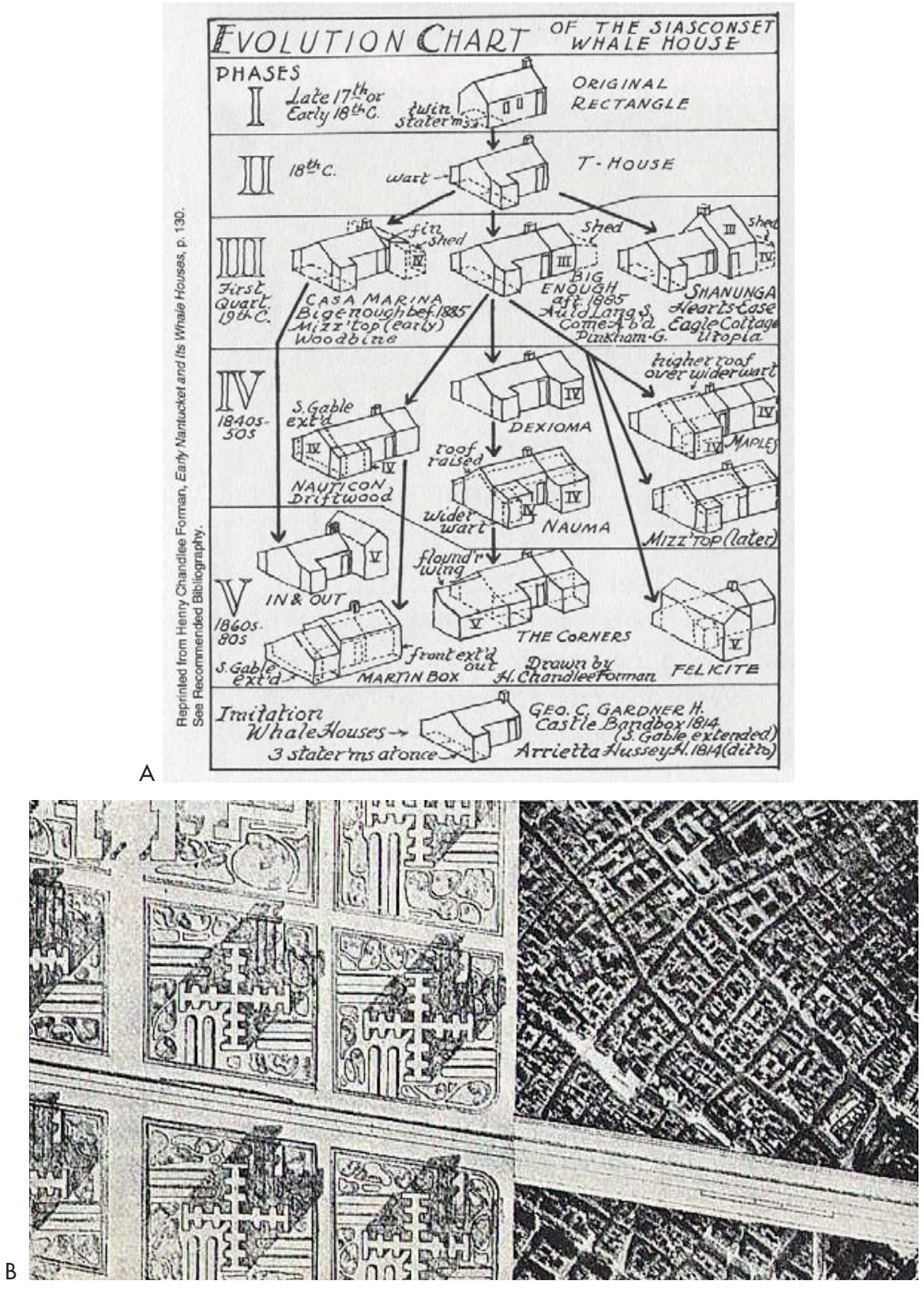
A. Henry Chandlee Forman. Evolution chart of the Siasconset Whale House (1966).

B. Le Corbusier. Plan Voisin (1925).
El resultado es que la significación ha quedado bajo sospecha, difícil de determinar y al mismo tiempo sobreexplotada en su asignación. Su proliferación, vinculada por un lado al gran proyecto democratizador de la cultura heredado de la Ilustración y, por otro, a la voluntad moderna de eliminar las diferencias y los privilegios del disfrute de la cultura asociados a la expansión del ocio, ha entrado hoy en un círculo de suspicacias. Procesos como el turismo cultural han supuesto cambios significativos al dejar de ser la cultura solo un mecanismo a través del cual la sociedad se realiza para convertirse en una industria de productos preparados para el consumo planetario. El salto del valor de uso al de valor de consumo tiene una doble implicación ya que, por una parte, se incrementa y fomenta lo patrimonial al convertirse en una fuente de ingresos y por otro surge la necesidad de poner en valor lo patrimonial para mantener e incrementar el flujo de turistas.

\subsubsection{La aproximación cuantitativa}

A las razones cualitativas podemos enfrentar unas razones cuantitativas, presentes en aquellos modos de preservar vinculados a metodologías que miden y evalúan el retorno de la preservación. Aunque los procesos de evaluación se han sofisticado, el objetivo final de preservar no ha cambiado. Reutilizar los espacios o la materia frente a empezar de cero es una práctica que viene de lejos. Debido a que lo construido tiende a sobrevivir a la función, los edificios a lo largo de la historia han sido adaptados a todo tipo de nuevos usos. De hecho, el patrón habitual hasta la Revolución Industrial era que los edificios se reutilizaran y sólo desde entonces se extendió la práctica de demoler para volver a construir de cero. La prescripción moderna para la racionalización e higienización de la ciudad abonaron los programas que fomentaban la sustitución de la ciudad por una nueva. Propuestas tan radicales como el Plan Voisin ideado por Le Corbusier para París y otros herederos se convirtieron en un modelo habitual de creación de ciudad por sustitución. En los últimos veinte años esta tendencia ha cambiado. No solo en la escala urbana, sino también en intervenciones puntuales. El énfasis por la conversión de edificios para nuevos usos no solo se da en los edificios históricos sino que se ha extendido a construcciones existentes independientemente de su valor cultural. En la práctica, esto ha significado que la preservación no implique concentrarse únicamente en el 


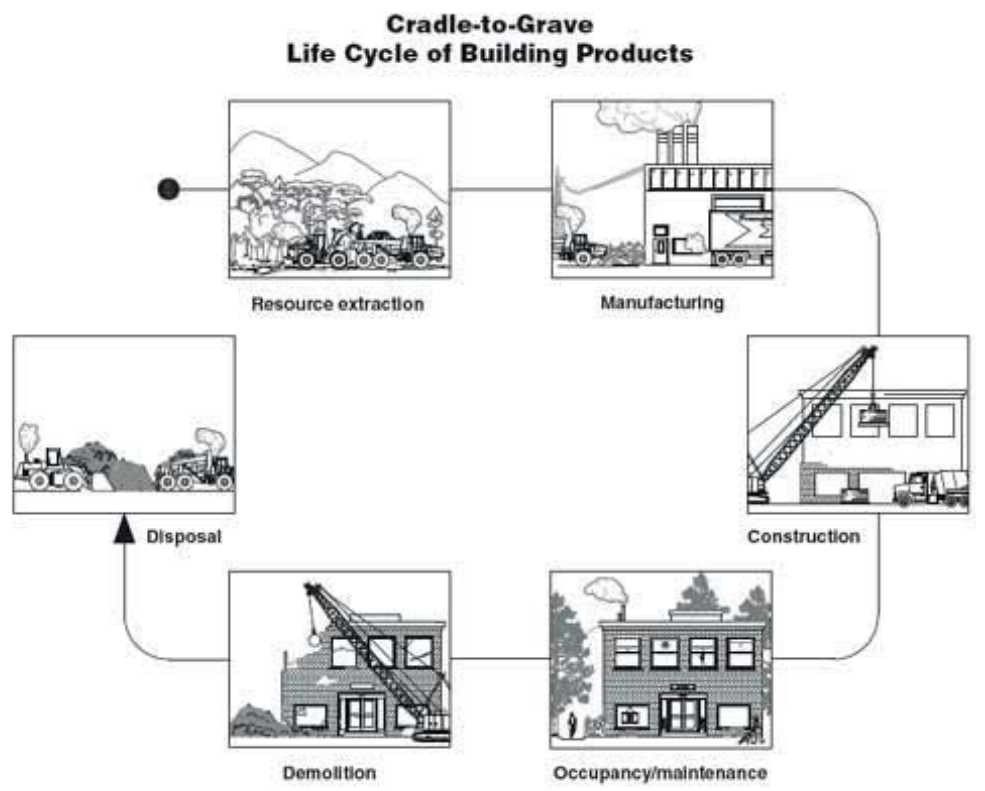

A

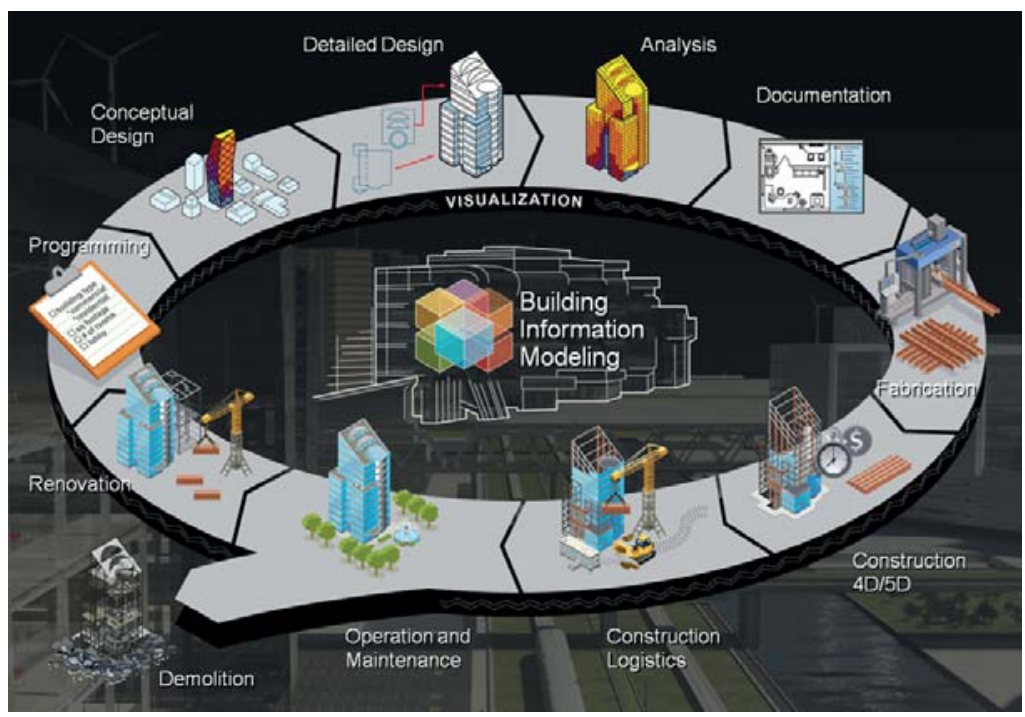


A. Cradle-to-grave (Desde la cuna hasta la sepultura). Diagrama del ciclo de vida de los productos empleados en la construcción de un edificio: extracción de los recursos, manufactura, construcción, ocupación y mantenimiento, demolición, eliminación de residuos.

B. Building Information Modeling (Modelado de un edificio). Diagrama del ciclo de vida de un edificio: programación, diseño conceptual, diseño detallado, análisis de comportamiento técnico documentación, fabricación, construcción 4D/5D (tiempo, presupuesto), logística, funcionamiento y mantenimiento, reforma o demolición.

84. Wilkinson, 2014: 4

85. Sus homólogos en inglés serían renovation, adaptive reuse, refurbishment, remodelling, reinstatement, retrofitting, conversion, transformation, rehabilitation, modernisation, re-lifing, restoration y recycling of buildings.

86. Gardner, 1989 mérito arquitectónico e histórico de los edificios amenazados sino que por el contrario se vea todo el parque de edificios existentes como potencialmente útil por razones económicas, energéticas o ecológicas así como una oportunidad para la regeneración urbana.

Todas estas aproximaciones han generado una literatura específica -fundamentalmente de origen anglosajón- basada en formas de preservación en las que se evalúa lo existente desde un punto de vista material conectado a ciclos y procesos dinámicos. El resultado es la proliferación de una nueva terminología que podría englobarse bajo el concepto común de Building Adaptation. Un término con múltiples interpretaciones y cuyas definiciones se refieren al cambio de uso, a la conservación máxima del edificio original, así como la ampliación de la vida útil del inmueble ${ }^{84}$. Términos como renovación, reutilización adaptativa, renovación, remodelación, restablecimiento, adaptación, conversión, transformación, rehabilitación, modernización, restauración y reciclaje de los edificios son utilizados indistintamente para definir las acciones vinculadas a la adaptación. ${ }^{85}$

El origen principal de estas corrientes se encuentra en las miradas ambientalistas. Lo que empezó en el siglo XIX como una contestación por parte de personajes y escritores involucrados en posiciones proteccionistas de los recursos naturales fue adquiriendo un cuerpo claro y global durante el siglo XX. La preocupación internacional por el medio ambiente quedó reflejada a través de la conferencia de la ONU en Estocolmo en 1972 y la proclamación de la idea de eco-development surgido como un enfoque de desarrollo orientado a la armonización de los objetivos sociales y económicos con una gestión ecológica racional. ${ }^{86} \mathrm{El}$ debate continuó sobre la definición apropiada del concepto de sostenibilidad, se argumentó que el desarrollo conducía inevitablemente a cierta disminución de las existencias de los recursos no renovables y que la sostenibilidad debía significar más que la preservación de los recursos naturales. La manera de fomentar una consciencia global sobre el problema, y de hacer partícipe a sociedad y gobiernos pasó por hacer visibles a través de métodos científicos de evaluación. Los primeros discursos que apelaban al vínculo empático con la madre tierra y la naturaleza fueron desplazados por los discursos cuantitativos que relacionaban el volumen de las emisiones con el aumento de la temperatura, la eliminación de recursos con el de número de muertes, enfermedades o especies desaparecidas, etc. 
A

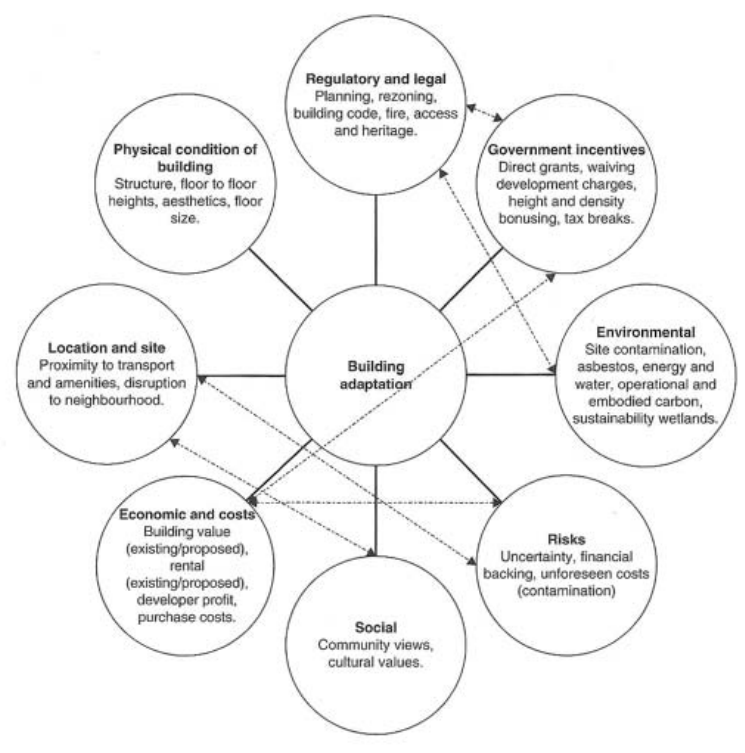

B
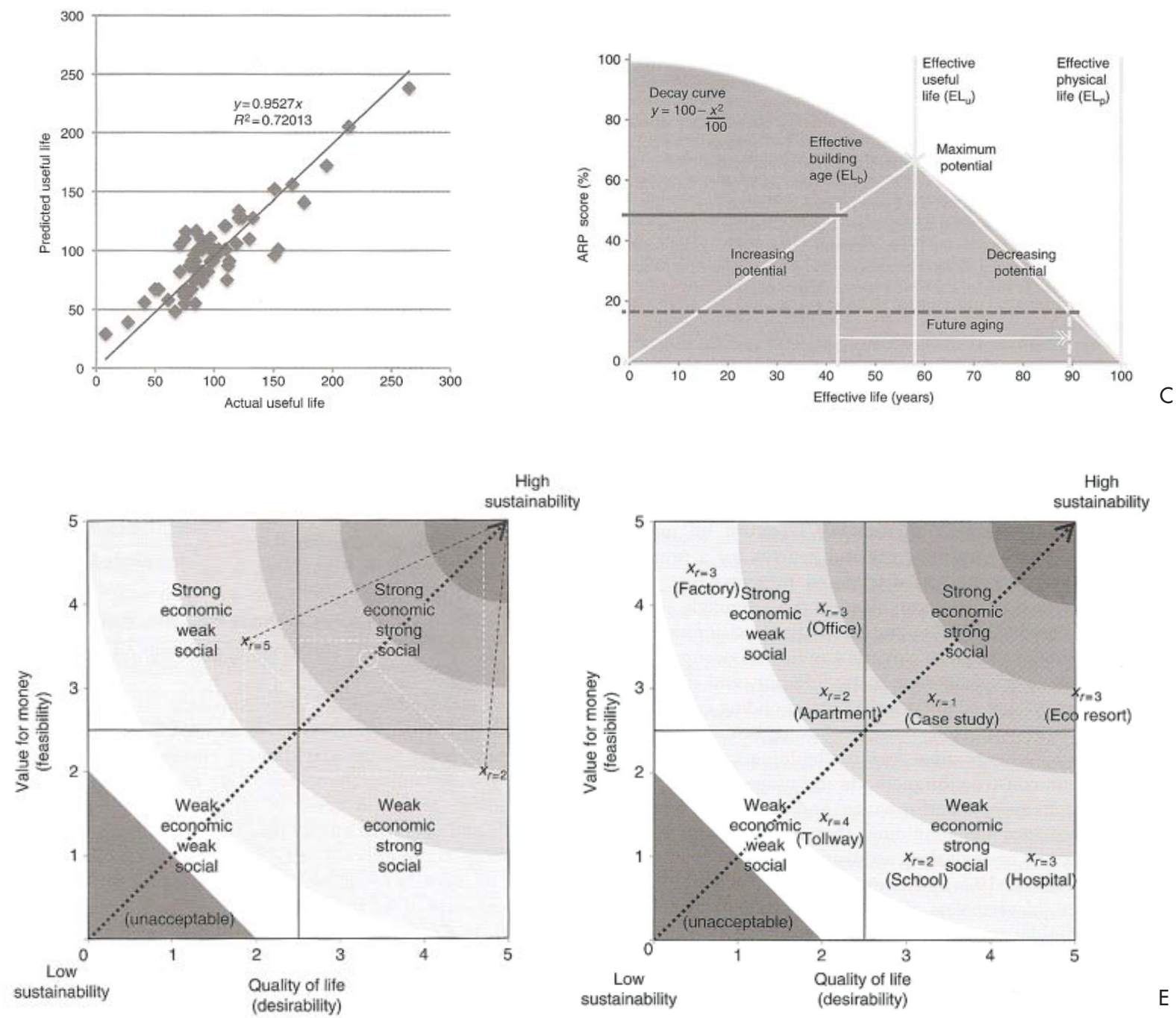
A. Adaptación del edificio. Modelo de factores de toma de decisiones en la adaptación de edificios B. Potencial de reutilización. Correlación entre predicción de vida mediante ARP y vida útil real $(n=64)$.

C. Adaptación y optimización. Concepto de modelo ARP de Langston.

D. Sostenibilidad. Esquema conceptual.

E. Adaptación y optimización. Comparación de tipos de infraestructuras.
87. Wilkinson, 2014

88. Con el tiempo, la utilidad de cualquier edificio para su función original disminuye; este proceso se conoce como la obsolescencia y representa una falta de utilidad. Obsolescencia toma varias formas, tales como la obsolescencia física, donde los edificios o sus partes componentes, literalmente, se desgastan. Obsolescencia funcional tiene lugar cuando la función original del edificio deja de ser operativa.

89. Latham, 2000
La arquitectura ha seguido también esa tendencia. La manera en la que hoy la preservación de lo construido se vincula a la sostenibilidad se fundamenta en cálculos de impacto. Como indica Sara Wilkinson ${ }^{87}$, la adaptación de edificios es inherentemente sostenible con el medio ambiente ya que implica un menor uso de materiales, es decir, menor utilización de recursos existentes, menos energía invertida para el transporte y consumo de materiales y menos contaminación durante la construcción. Aun cuando los costos económicos para la adaptación son altos, el argumento medioambiental junto con los factores sociales influyen en las decisiones a favor de la adaptación. Las acciones de demolición son procesos de desperdicio en términos materiales, por eso desde finales de 1990 el concepto de sostenibilidad ha sido uno de los principales impulsores de la adaptación bajo la noción de reciclaje de edificios. Según Wilkinson, la mejora del rendimiento de lo existente a través de la de la reutilización es el aspecto más crítico para la mejora de la sostenibilidad del entorno construido. Por esa razón, los procesos de evaluación para determinar las posibles vidas futuras de los edificios han sido explorados ampliamente. Se han desarrollado métodos de análisis cuantitativo para la comparación de alternativas y sacar los mejores rendimientos según los tipos de obsolescencia. ${ }^{8}$

El objetivo final de estos formatos de adaptación sería prolongar el periodo de vida de un edificio mediante la utilización de la totalidad o de la mayor parte de su sistema estructural y de otros elementos como los revestimientos, cerramientos o particiones interiores. El sistema de medida se homogeniza a través de unidades comparables. Todos los edificios se pueden analizar a través de la energía invertida o las emisiones de carbono. La energía o las emisiones de carbono que resultan de la extracción de los materiales en bruto más la transformación en componentes constructivos y el transporte al lugar de construcción dan la medida de los costes de transformación. Reutilizar, readaptar, o reapropiarse de arquitecturas existentes bajo la perspectiva del ciclo de vida de las mismas y buscando que se prolonguen en el tiempo son la forma de hacer que esa energía invertida perviva de la forma más eficaz. ${ }^{89}$

$\mathrm{Al}$ actuar sobre los edificios que están significados, las razones cuantitativas se han incorporado en la toma de decisiones y han permitido redefinir los modos de conservación mediante una doble apreciación que funciona en ambas direcciones, desde lo material y lo inmaterial. En cambio, para el 


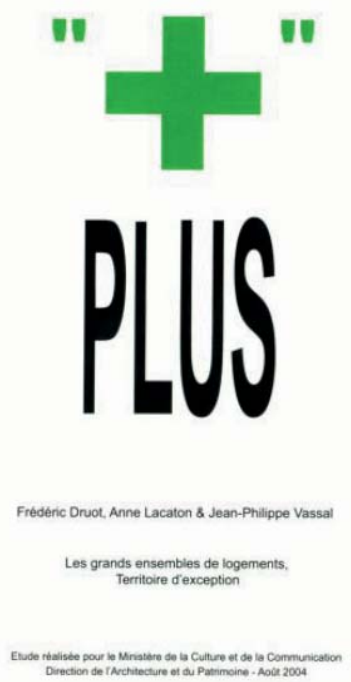

A

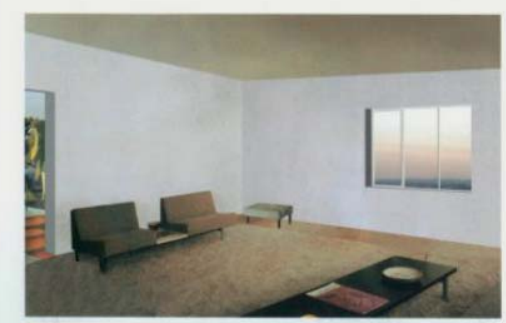

ELECTROCHOC

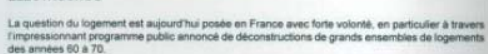

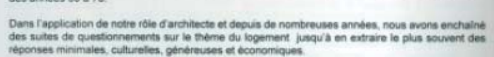

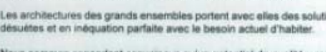
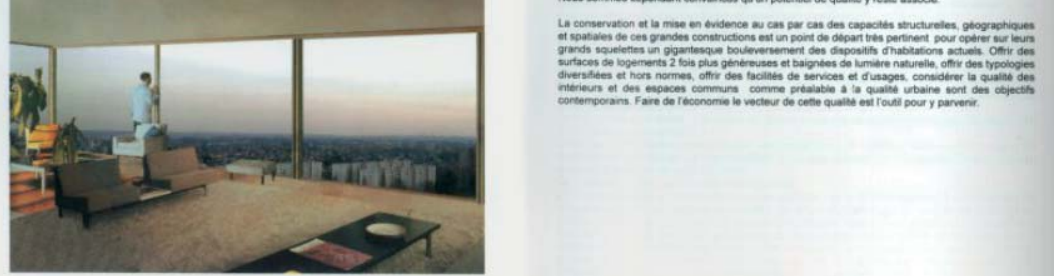
A. Portada de Plus. Frederic Druot, Anne Lacaton y Jean-Philippe Vassal. Documento de 2004.

B. Páginas 8 y 9 de Plus. Frederic Druot, Anne Lacaton y Jean-Philippe Vassal. Documento de 2004.
90. El éxito y ansia por colocar paneles solares frente a otro tipo de acciones posibles es un ejemplo de estas actitudes.

91. El documento es accesible por internet. Véase Druot, Lacaton \& Vassal, 2004

92. "El concepto de aplazar el juicio, introducido por Koolhaas ya en la década de 1980, fue un intento para que el arquitecto se confrontase nuevamente con realidades que una arquitectura, que se definía crítica, tendía a excluir. Koolhaas argumentaba con razón que, aunque la sociedad de consumo nos parezca alienante, estamos obligados a confrontarnos con ella, pues el acto de comprar impregna cada vez más nuestra vida cotidiana. De este modo Koolhaas abrió al discurso crítico una serie de áreas moralmente contaminadas hasta entonces. La estrategia del juicio suspendido concebida como ética de la percepción, permite a la arquitectura confrontarse con la realidad en vez de reprimirla. Esta estrategia amplía la capacidad de acción de los arquitectos tanto más cuanto más crítica parezca la realidad a la que se enfrentan." Ilka y Andreas Ruby en Druot, Lacaton \& Vassal, 2007 resto, para los que no están significados, para lo que llamamos lo ordinario, estos sistemas cuantitativos se han extendido como el método fundamental para valorar su supervivencia y también han contagiado a las herramientas proyectuales que, condicionadas por las normativas, han asumido como inevitables y necesarios los sistemas tecnológicos que operan desde las lógicas de los cálculos de rendimiento y retorno. ${ }^{90}$ Son escasas y puntuales las aproximaciones que desafían estas aproximaciones. Para encontrar un cuerpo teórico armado y sólido que entienda e incorpore la intersección entre las sensibilidades de lo simbólico y lo numérico hay que situarse en el siglo presente. Es el caso de la obra de Anne Lacaton y Jean-Philippe Vassal. En sus propuestas, las evaluaciones cuantitativas son un elemento más de preservación basada en la capacidad de las arquitecturas existentes de adoptar o ser operadas desde una dimensión cultural y afectiva.

\subsection{PLUS: UN MANIFIESTO}

El panorama al que se enfrentaban Druot, Lacaton \& Vassal al tratar de defender del derribo los bloques de viviendas de la postguerra era el siguiente: un material arquitectónico perteneciente al ámbito de la arquitectura ordinaria, fuera por lo tanto de los criterios de conservación del patrimonio, con una carga negativa debido al desapego social y que había sido sentenciado a desaparecer. El objetivo del informe era convencer al gobierno francés de la necesidad de mantener su existencia. El informe se realizó bajo el encargo de la Direction de l'Architecture et du Patrimoine del Ministère de la Culture et de la Communication en Agosto de 2004. ${ }^{91}$

El documento es, en palabras de Ilka y Andreas Ruby, la "formulación de una nueva estrategia para la regeneración para los grandes conjuntos de viviendas en Francia" cuya máxima virtud es la de aproximarse al tema a través de la "suspensión del juicio"92. Aquí nos aventuramos a decir que es al mismo tiempo una investigación y un manifiesto, quizá el último publicado en la arquitectura reciente. Una declaración de intenciones ambiciosa que va más allá de lo local para proponer un andamiaje intelectual y práctico sobre el que defender la pertinencia y la necesidad de aprovechar lo construido en la creación de la ciudad. 


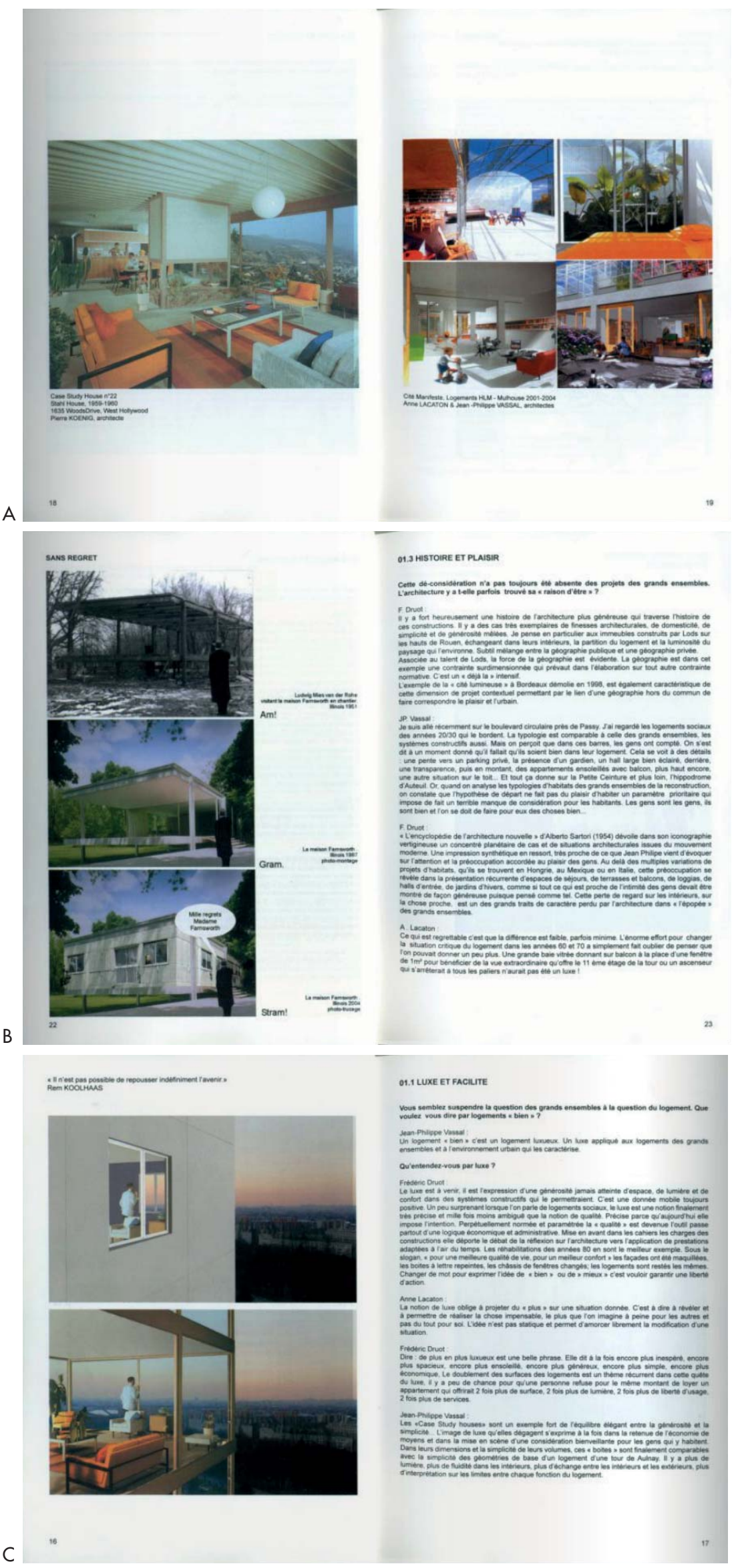


A. Páginas 16 y 17 de Plus. Frederic Druot, Anne Lacaton y Jean-Philippe Vassal. Documento de 2004.

B. Páginas 18 y 19 de Plus. Frederic Druot, Anne Lacaton y Jean-Philippe Vassal. Documento de 2004.

C. Páginas 22 y 23 de Plus. Frederic Druot, Anne Lacaton y Jean-Philippe Vassal. Documento de 2004.
93. Las diferencias entre ambas son menores. La versión impresa cuenta con un texto introductorio realizado Ilka y Andreas Ruby titulado Recuperar el Movimiento Moderno mientras que el El texto del preámbulo del texto original titulado Electrochoc desaparece en esta versión impresa; por el contrario los apartados 03.1 Attitude y 03.2 Economie del informe se desplazan a la introducción del libro, quedando el último ligeramente reducido a enunciado Transformation; y por último en el libro se incorpora un nuevo capítulo titulado Proyectos, en el que se materializa la investigación en un par de ejemplos en construcción, Petit Maroc en SaintNazaire y la torre Bois-le-Prêtre en Paris.
Del documento existen dos versiones, la original presentada al Ministerio de Cultura francés en 2004 y la versión publicada años después, en 2007, por la editorial Gustavo Gili como libro en edición trilingüe: castellano, francés e inglés. ${ }^{93}$ Tomaremos para nuestro análisis la segunda versión, editada bajo la supervisión de los autores, y por ser la última, la que podría considerarse definitiva. El libro cuenta con seis capítulos.

El capítulo uno, titulado Actitud, contiene dos textos. El primero es el "manifiesto" del libro, en el que se hacen explícitos los principios que recorren toda la investigación. El segundo texto se titula ¿Viviendas? Zonas por explotar, un texto rescatado de Jacques Hondelatte publicado originalmente en la revista Architecture d'Aujourd'bui, n²39. Como veremos más adelante, el texto trae al documento una perspectiva cultural que será relevante para nuestra interpretación del informe.

El capítulo dos lleva el título de Plus y desarrolla el manifiesto en nueve puntos: Lujo y facilidad; Masa y sistema; Historia y placer; Territorios de excepción; Estado de cuentas; Eco-cultura; Normas; Electrochoque; y Vida Pública. La peculiaridad de este apartado es que esos principios no se enuncian como un texto continúo sino como una colección de extractos, una conversación ordenada por temas, en los que se identifican las voces de los tres autores. El texto se acompaña de imágenes y montajes fotográficos expresivos, incluso irónicos en ciertas ocasiones, que no resultan ser solo ilustraciones de las ideas sino que en sí mismos también resultan ser manifiestos.

El capítulo tres, Catálogo, es una recopilación de estrategias para intervenir en los edificios, por un lado atendiendo a las viviendas y por otro a los espacios comunes. Mediante un repertorio principalmente gráfico, revisan los diferentes espacios domésticos interiores -habitaciones, aseos, cocina, salón- y los espacios comunes -corredores, cajas de escaleras, instalaciones y vestíbulo de acceso- proponiendo actuaciones y medidas concretas sobre lo construido.

El capítulo cuatro reúne el estudio sobre emplazamientos concretos sobre los que el libro propone unas medidas de actuación que incluyen la transformación de lo existente y adición de nuevas superficies en altura en torno a los bloques construidos. Las cuatro localizaciones elegidas son: Aulnay-sous-Bois, Le Havre, Nantes y Trignac 


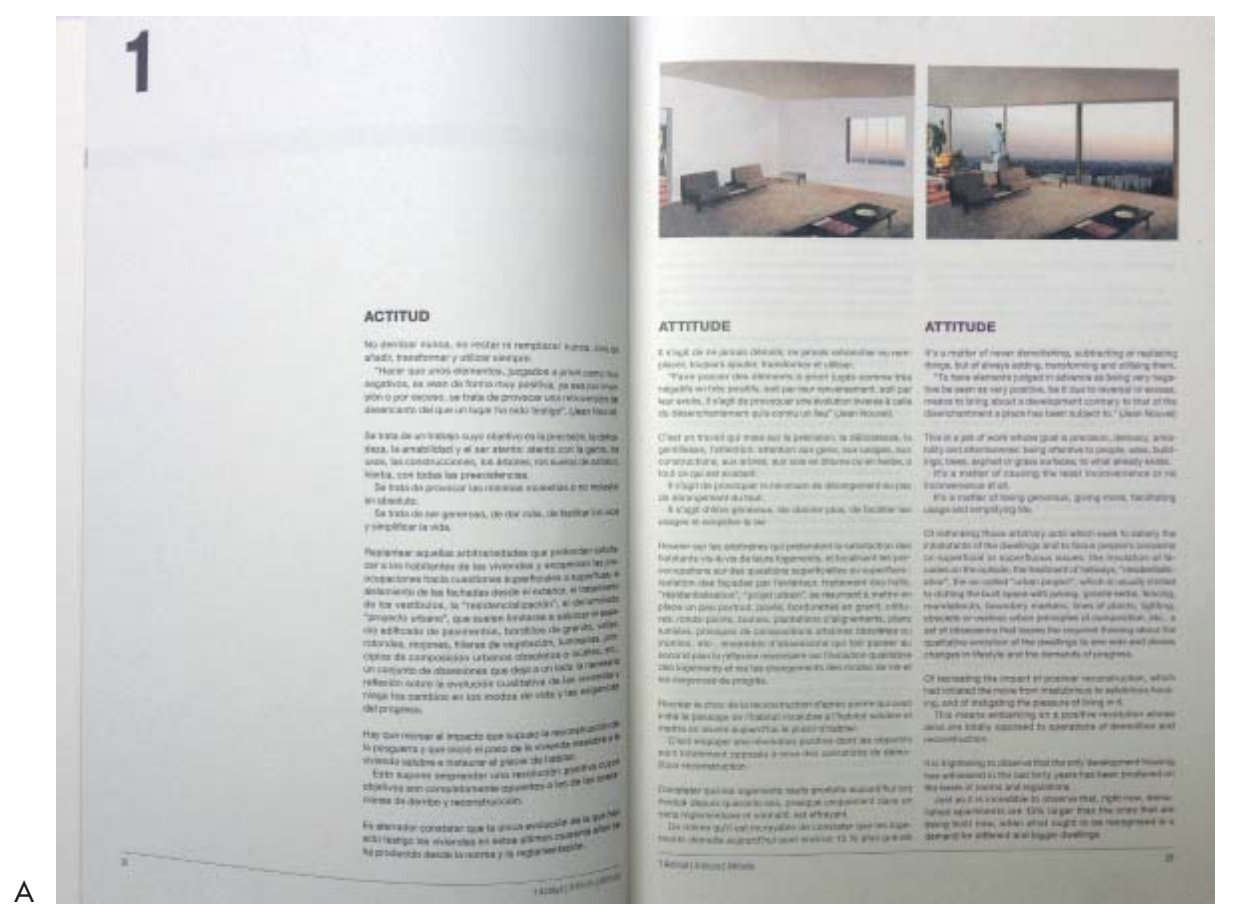


A. Páginas 16 y 17 de Plus. Frederic Druot, Anne Lacaton y Jean-Philippe Vassal. Documento de 2007.
El capítulo quinto, denominado Proyectos, incluye dos obras en proceso de construcción de los arquitectos Druot, Lacaton \& Vassal: Petit Maroc en Saint-Nazaire y la Torre de Bois-le-Prêtre en París. Estos proyectos se incluyen en el libro, pasados casi cuatro años del primer documento presentado al gobierno francés y son la traducción de sus ideas a casos concretos. Demuestran la viabilidad y los argumentos del manifiesto.

El capítulos seis, $X$ veces + , es una conclusión y al mismo tiempo la interpretación de como las actuaciones sobre los edificios suponen también, por contagio, una transformación de la ciudad, como si de una onda expansiva se tratara.

\subsubsection{Principios Plus}

Plus es ante todo una declaración de intenciones. El texto inicial del manifiesto fija su posicionamiento:

\section{“ACTITUD}

No derribar nunca, no restar ni reemplazar nunca, sino de añadir, transformar y utilizar siempre.

'Hacer que unos elementos, juzgados a priori como muy negativos, se vean de forma muy positiva, ya sea por inversión o por exceso, se trata de provocar una retroversión del desencanto del que un lugar ha sido testigo'. Jean Nouvel

Se trata de un trabajo cuyo objetivo es la precisión, la delicadeza, la amabilidad y el ser atento: atento con la gente, los usos, las construcciones, los árboles, los suelos de asfalto o hierba, con todas las preexistencias.

Se trata de provocar las mínimas molestias o no molestar en absoluto, Se trata de ser generoso, de dar más, de facilitar los usos y simplificar la vida.

Replantear aquellas arbitrariedades que pretenden satisfacer a 

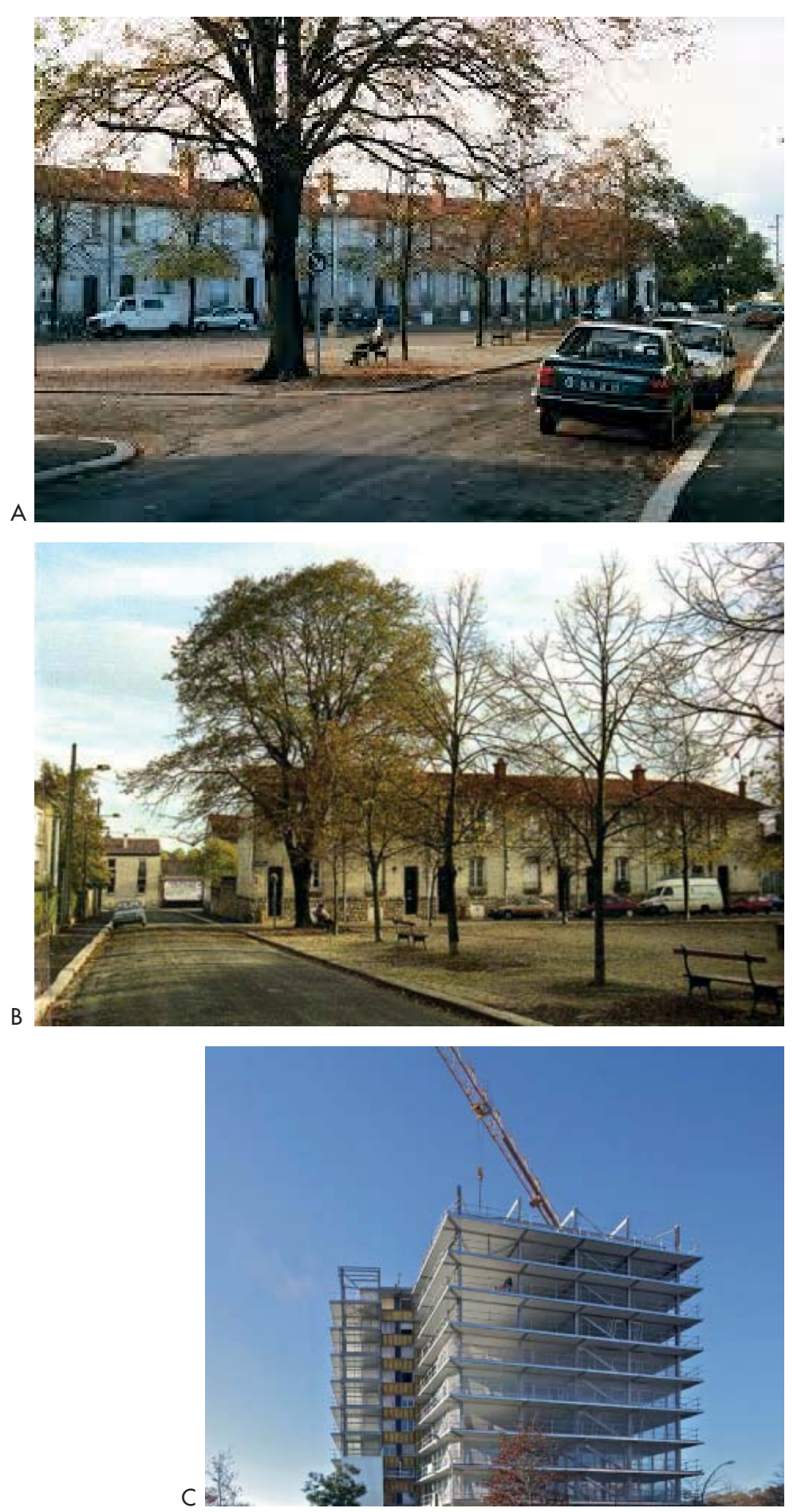
A-B. Lacaton \& Vassal. Place Léon Aucoc Bordeaux (1996).

C. Lacaton \& Vassal. Transformation d'un immeuble de logements, Saint-Nazaire (2014). los habitantes de las viviendas y encaminan las preocupaciones hacia cuestiones superficiales o superfluas: el aislamiento de las fachadas desde el exterior, el tratamiento de los vestíbulos, la "residencialización", el denominado "proyecto urbano", que suelen limitarse a salpicar el espacio edificado de pavimentos, bordillos de granito, vallas, rotondas, mojones, hileras de vegetación, luminarias, principios de composición urbanos obsoletos o inútiles, etc., un conjunto de obsesiones que deja a un lado la necesaria reflexión sobre la evolución cualitativa de las viviendas y niega los cambios en los modos de vida y las exigencias del progreso.

Hay que recrear el impacto que supuso la reconstrucción de la posguerra y que inició el paso de la vivienda insalubre a la vivienda salubre e instaurar el placer de habitar.

Esto supone emprender una revolución positiva cuyos objetivos son completamente opuestos a los de las operaciones de derribo y reconstrucción.

Es aterrador constatar que la única evolución de la que han sido testigos las viviendas en estos últimos cuarenta años se ha producido desde la norma y la reglamentación.

Del mismo modo que es increíble constatar que, en la actualidad, las viviendas que se derriban son un 15\% más grandes que las que se construyen, cuando lo que se impone es una demanda de viviendas diferentes y más grandes." 94

El texto expone simultáneamente una formulación y una crítica. Por un lado, se propone la reivindicación de lo existente como un material de trabajo estigmatizado que puede ser revalorizado, una vez suspendido el juicio, con la sensibilidad de los afectos. Por otro, una crítica hacía los posicionamientos administrativos y normativos que han reducido la libertad y la calidad de la vivienda y que pone en evidencia el parón crítico que se ha instalado en el pensamiento arquitectónico de lo doméstico desde la postguerra. A lo largo del resto del texto se van desarrollando las ideas que amplían y defienden estas posiciones. El entramado discursivo del libro puede parecer a priori confuso, pero una mirada atenta descubre una intención persuasiva que funciona en varias direcciones. 

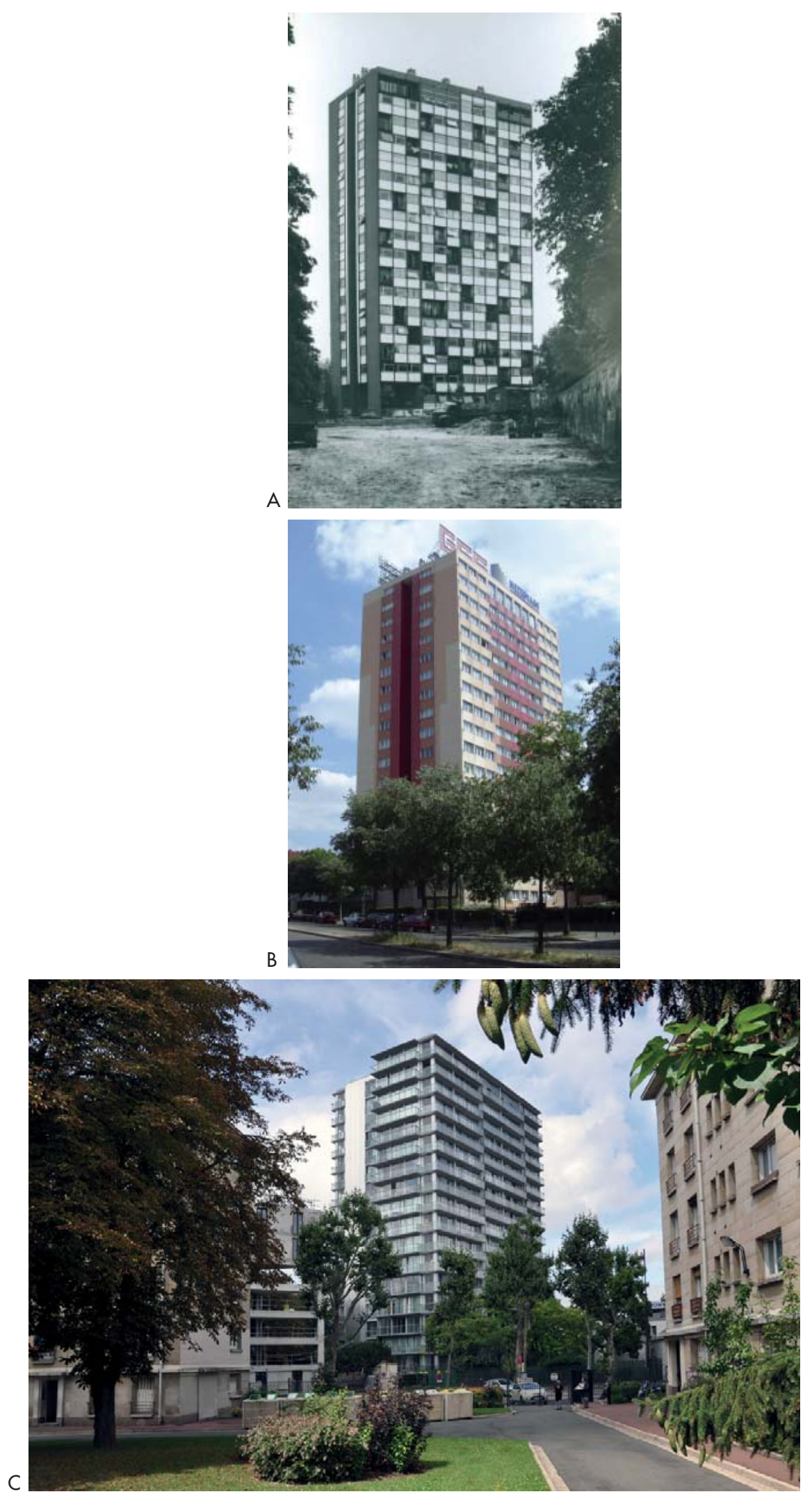
A. Edificio residencial Bois Le Prêtre, París.

B. Edificio residencial Bois Le Prêtre antes de su reforma de 2013

C. Frédéric Druot Architecture y Anne Lacaton

\& Jean Philippe Vassal. Reforma del edificio

residencial Bois Le Prêtre, París (2013).

\subsubsection{Suspensión del juicio}

Como los autores enuncian al principio del texto, su programa de preservación tiene como enemigo la percepción negativa que existe sobre los complejos habitacionales. El desencanto crítico creado desde los propios ámbitos culturales hacia la arquitectura moderna, el evidente deterioro de los espacios comunes de los edificios -entorno, fachadas, vestíbulos,...- y la dejadez por parte de los poderes municipales se había convertido, como demuestran Druot, Lacaton \& Vassal, en un obstáculo para la conservación. Las actualizaciones realizadas sobre esos edificios se habían limitado a desafortunadas y miopes actuaciones según normativas de ahorro energético. El resultado no había podido ser menos estimulante y el veredicto final para los complejos habitacionales acabó por aconsejar su derribo y sustitución.

De ahí que recurran a la cita de Jean Nouvel que apela a transformar los juicios negativos y a la "retroversión del desencanto" para reafirmar su posicionamiento. Al tratarse de un manifiesto sorprende el uso de esta cita en el texto, pues no parece relevante por el contenido del mismo, y rompe además, su carácter de alegato personal. Sin embargo tiene sentido en la forma de articular un discurso "desde fuera". Y seguramente esa sea la primera característica que sobrevuela el texto: el cambio en las herramientas de la batalla. Esta actitud recuerda a un estado de epojé hacia el material construido, no lo valoran ni lo condenan. Frente a otros manifiestos que enarbolan su discurso desde una movilización cultural en el texto de Plus se elude, aparentemente de forma intencionada, esa forma de cruzada. No defienden los edificios modernos desde lo significado o por su valor arquitectónico como cabría de esperar de un arquitecto. No los enlazan con la historia y no los reivindican como objeto. Más bien despliegan una mirada compasiva. Lejos de apelar a su condición moderna y heroica, muestran una cierta ternura comprensiva para justificarlos. Los respetan pero no los idolatran como afirma Jean-Philippe Vassal:

"la arquitectura de los grandes conjuntos de viviendas es defendible en el contexto en que fue pensada. Su gran carencia, como ya se ha comentado, fue no establecer continuidades ni correspondencia con el proyecto moderno de su tiempo." ${ }^{95}$ 

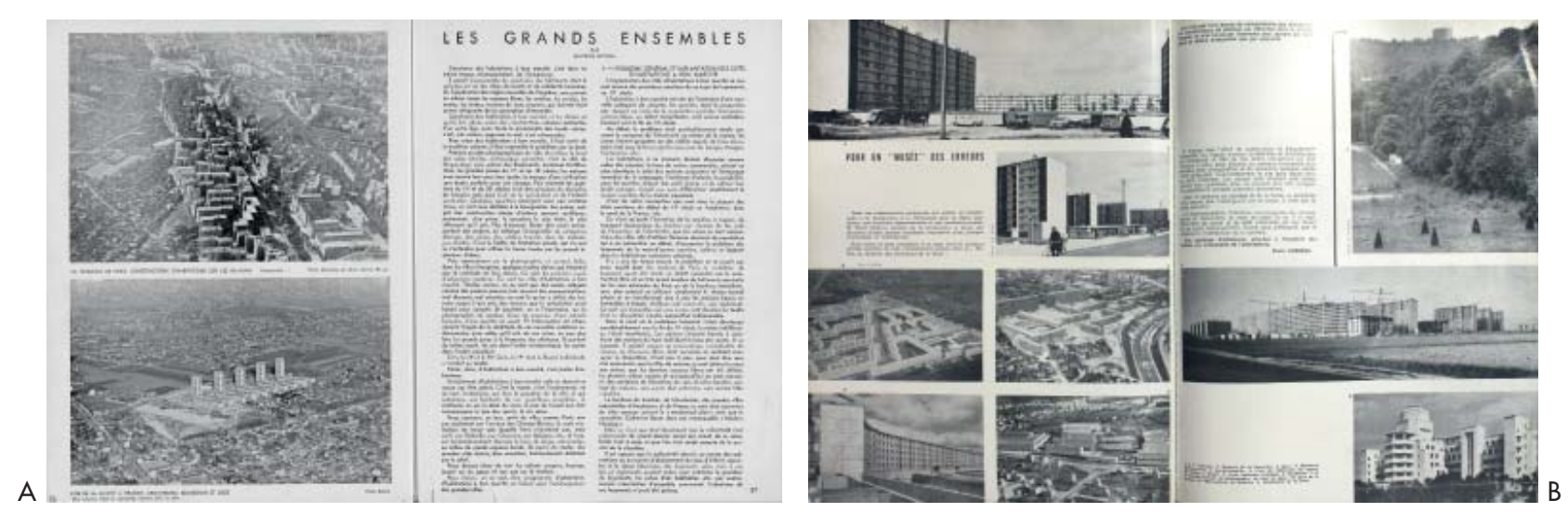

NUEVAS TIPOLOGIAS

NOUVELLES TYPOLOGIES

NEW TYPOLOGIES

\begin{tabular}{|c|c|c|c|c|}
\hline TIPOLOGIA ACTUAL & ESTADO ACTUAL & PROYECTO & NUEVAS TIPOLOGIAS & DESPUÉS \\
\hline T2 lado este & \multirow[t]{2}{*}{36} & & $\begin{array}{l}\text { T2 pequefio o } \\
\text { T1bis (eliminando una divisoria) }\end{array}$ & $14 \mathrm{~T} 1$ \\
\hline T2 lado oeste & & recuperacion del local del rellano & $\mathrm{T} 2$ & $25 \mathrm{~T} 2$ \\
\hline \multirow{3}{*}{$\mathrm{T} 3$} & \multirow{3}{*}{28} & sin prolongación & $\begin{array}{l}\text { T3 pequeño o } \\
\text { T2 grande (eliminando una divisoria) }\end{array}$ & \multirow{2}{*}{$18 \mathrm{~T} 3$} \\
\hline & & $\mathrm{T} 3$ + 1 tramo $\left\langle 18 \mathrm{~m}^{2}\right\rangle$ & T3 & \\
\hline & & $\mathrm{T} 3+2$ tramos $\left(2 \times 18 \mathrm{~m}^{2}\right)$ & $\mathrm{T} 4$ & $30 \mathrm{~T} 4$ \\
\hline \multirow[t]{2}{*}{ T5/6 } & \multirow[t]{2}{*}{32 (T6) } & $\begin{array}{l}-3 \mathrm{~m}^{2} \text { (cocina) } \\
\text { sin prolongación }\end{array}$ & $\begin{array}{l}\text { T6 pequeño } 0 \\
\text { T5 (eliminando una divisoria) }\end{array}$ & $04 \mathrm{TS}$ \\
\hline & & $\begin{array}{l}-3 \mathrm{~m} 2 \text { (cocina) } \\
+1 \text { tramo }\left(18 \mathrm{~m}^{2}\right\}\end{array}$ & T6 & $13 \mathrm{~T} 6$ \\
\hline Total & 96 & & & 104 \\
\hline
\end{tabular}

\begin{tabular}{|c|c|c|c|c|}
\hline TYPOLOGIB ACTUELLE & EXISISTANT & PROJET & NOUVELLES TYPOLOGIES & APRES \\
\hline T2 côté est & \multirow[t]{2}{*}{36} & & $\begin{array}{l}\text { petit T2 ou } \\
\text { T1bis (en supprimant une cloison) }\end{array}$ & $14 \mathrm{~T} 1$ \\
\hline T2 côté ouest & & récuperation du local sur le palier & T2 & $25 \mathrm{~T} 2$ \\
\hline \multirow{3}{*}{ T3 } & \multirow{3}{*}{28} & sans extension & $\begin{array}{l}\text { petit T3 ou } \\
\text { grand T2 (en supprimant une cloison) }\end{array}$ & \multirow{2}{*}{$18 \mathrm{~T} 3$} \\
\hline & & $\mathrm{T} 3+1$ trame $\left(18 \mathrm{~m}^{2}\right)$ & T3 & \\
\hline & & $\mathrm{T} 3+2$ trames $\left(2 \times 18 \mathrm{~m}^{2}\right)$ & $\mathrm{T} 4$ & $30 \mathrm{~T} 4$ \\
\hline \multirow[t]{2}{*}{ T5/6 } & \multirow[t]{2}{*}{$32(\mathrm{~T} 6)$} & $\begin{array}{l}-3 \mathrm{~m}^{2} \text { (cuisine) } \\
\text { sans extension }\end{array}$ & $\begin{array}{l}\text { petit } T 6 \text { ou } \\
\text { T5 (en supprimant une cloison) }\end{array}$ & $04 \mathrm{~T} 5$ \\
\hline & & $\begin{array}{l}-3 \mathrm{~m}^{2} \text { (cuisine) } \\
+1 \text { trame }(18 \mathrm{~m} 2)\end{array}$ & T6 & $13 \mathrm{~T} 6$ \\
\hline Total & 96 & & & 104 \\
\hline
\end{tabular}

\begin{tabular}{|c|c|c|c|c|}
\hline CURRENT TYPOLOGY & CURRENT STATEE & PROJBCT & NEW TYPOLOGIES & AFTERWARDS \\
\hline \multirow[t]{2}{*}{ T2 east side } & \multirow[t]{2}{*}{36} & & $\begin{array}{l}\text { smal1 T2 or } \\
\text { T1bis (by eliminating a partition) }\end{array}$ & $14 \mathrm{~T} 1$ \\
\hline & & $\begin{array}{l}\text { rehabilitation of the room on } \\
\text { the landing }\end{array}$ & T2 & $25 \mathrm{~T} 2$ \\
\hline \multirow{3}{*}{ T3 } & \multirow{3}{*}{28} & without extension & $\begin{array}{l}\text { mall } \mathrm{T} 3 \text { or large } \mathrm{T} 2 \\
\text { (by eliminating a partition) }\end{array}$ & \multirow{2}{*}{$18 \mathrm{~T} 3$} \\
\hline & & $\mathrm{T} 3+1$ extension strip $\left\langle 18 \mathrm{~m}^{2}\right\rangle$ & T3 & \\
\hline & & $\mathrm{T} 3+2$ extension strips $\left(2 \times 18 \mathrm{~m}^{2}\right)$ & T4 & $30 \mathrm{~T} 4$ \\
\hline \multirow[t]{2}{*}{$\mathrm{T} 5 / 6$} & \multirow[t]{2}{*}{32 (T6) } & $\begin{array}{l}-3 \mathrm{~m}^{2} \text { (kitchen) } \\
\text { without extension }\end{array}$ & $\begin{array}{l}\text { small T6 or } \\
\text { T5 (by eliminating a partition) }\end{array}$ & 04 T5 \\
\hline & & $\begin{array}{l}-3 \mathrm{~m}^{2} \text { (kitchen) } \\
+1 \text { extension strip }\left(18 \mathrm{~m}^{2}\right)\end{array}$ & T6 & $13 \mathrm{~T} 6$ \\
\hline Total & 96 & & & 104 \\
\hline
\end{tabular}


A. Páginas 56 y 57 de L'Architecture d'Aujourd'hui. Vol. 1, n. 6 (Junio 1935), artículo de M. Rotival, Les Grands Ensembles.

B. Páginas 10 y 11 de L'Architecture d'Aujourd'hui. N. 95 (1961), artículo de P. Sudreau, Pour un musée des erreurs, (Para un Museo de los errores). C. Frédéric Druot Architecture y Anne Lacaton \& Jean Philippe Vassal. Presupuesto de la reforma del edificio residencial Bois Le Prêtre, París (2013)
97. Díaz Moreno y García Grinda, 2015: 14
Arnoldo Rivkin, en su revisión de la obra de Lacaton \& Vassal, aporta una visión similar a la que defendemos:

"El trabajo de Lacaton \& Vassal no se apoya ni sobre la memoria, ni sobre su opuesto complementario, la amnesia"96

El hallazgo del libro es precisamente dejar morir la batalla de la preservación histórica, no recurrir a ella en ningún caso y, por el contrario, aludir desde el primer momento a los intereses económicos como la base de su fundamento. Esta estrategia desideologiza históricamente la actuación y la libera de ataduras con respecto a su pasado reciente. Dado que no se reivindican los habituales principios de la significación estos quedan fuera del debate, los desactivan. Plus renuncia al arma principal de los manifiestos de las vanguardias, su dialéctica de oposición histórica, para encontrar un camino en el mundo de hoy movilizado fundamentalmente por lo económico. Es una forma de decir que todo lo que se había construido en la década de 1960 puede ser revisado sin odio pero sin sumisión y que es necesario sacar partido del potencial existente mediante un cambio de criterio. El objetivo del proyecto se desplaza a la gestión de los recursos. De ahí que la justificación principal esgrimida en el libro para la preservación sea que el coste de derribar y volver a construir comparado con el de mantener y ampliar es rotundamente favorable a esta segunda opción. Para demostrarlo dedican una amplia parte del libro a evaluar los costes de la intervención sobre los edificios en comparación con lo que costaría hacerlos de cero. Otra vez nos encontramos con una rareza: un manifiesto con presupuesto. Como expresa Jean-Philippe Vassal:

"Para nosotros está claro que usando lo que ya existe puedes hacer más con menos. Si demueles, se pierde uno y se reconstruye uno; así que, al final, sigues teniendo uno. Por un lado, gastas un montón de energía, tiempo y dinero en obtener sólo uno; y por otro, si añades la mitad obtienes uno y medio. Y, al mismo tiempo, das una respuesta a la preocupación general existente sobre la sostenibilidad.”97

El título del libro adquiere, desde esa perspectiva, un sentido revelador. Plus, más, es literalmente un forma de apelar a una inversión positiva. Sin embargo la evaluación económica no se convierte un fin en sí mismo. Es solo 

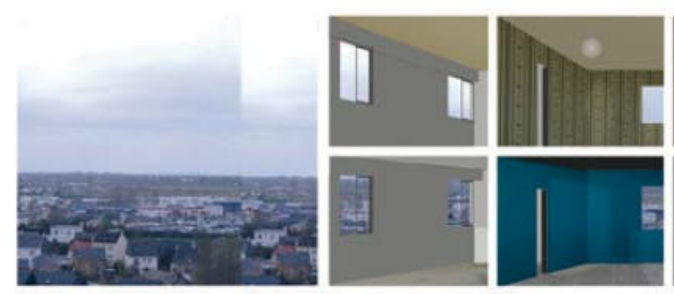

T4 existant $62 \mathrm{~m}^{2}$

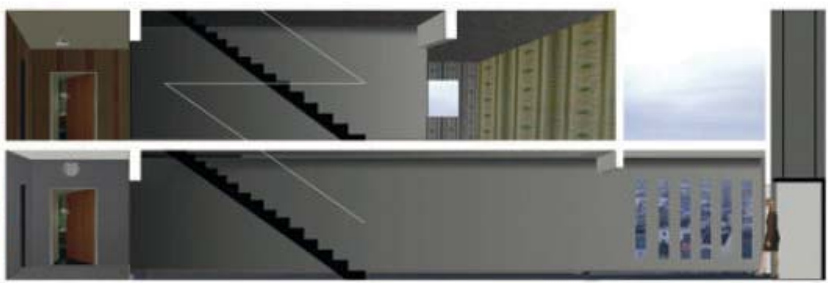

Desserte ascenseur existant
1 palier sur 3

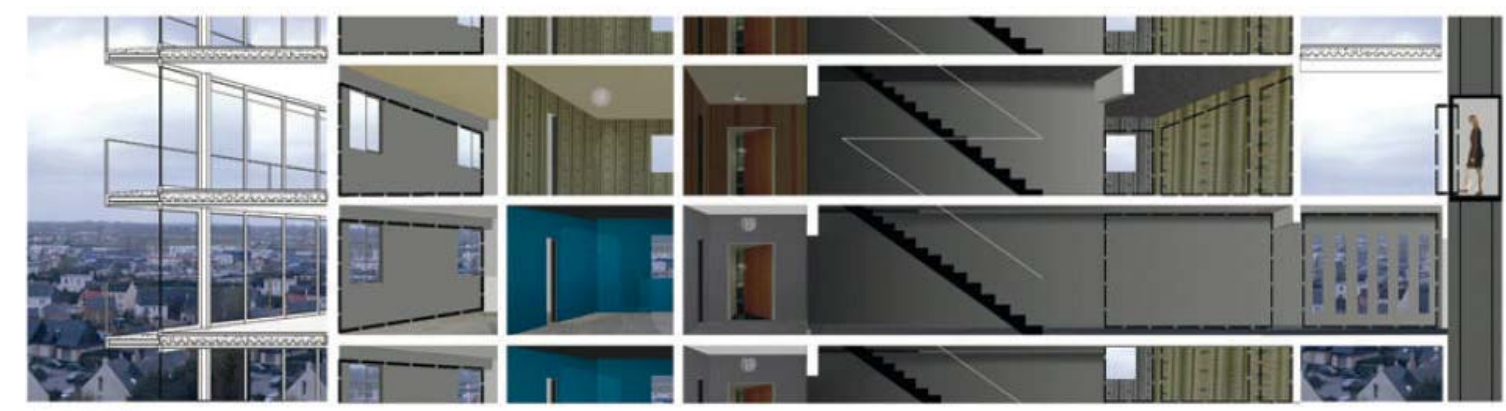

Ajout de balcon $\begin{array}{ll}\text { en béton préfabriqué } & \text { en bac acier collaborant structure poteaux poutres } \\ \text { sur corbeaux métallique } & \text { métalliques }\end{array}$

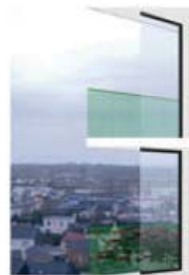

Extension,

Terrasse,

Transparence.

A
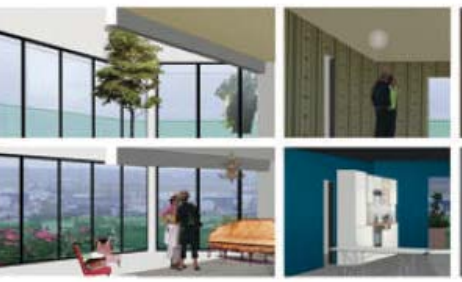
Appartement $144 \mathrm{~m}^{2}$ Sejour $51 \mathrm{~m}^{2}$

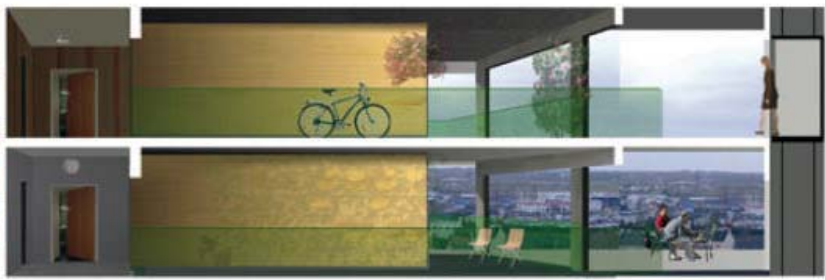

Desserte ascenseur

Terrasse devant le logement 
A. Frédéric Druot Architecture y Anne Lacaton \& Jean Philippe Vassal. Diagrama de la evolución de la reforma del edificio residencial Bois Le Prêtre, París (2013).
98. Rivkin, 2015: 32

99. Para profundizar este tema se recomienda leer el texto "Una cartografía imaginaria" de lñaki Ábalos en el que, con un visón certera, define estos principios como universales: "Conscientes de que los problemas de la arquitectura son universales- en el espacio y en el tiempo- y sometidos exclusivamente a esa mediación entre cultura y naturaleza que es la técnica, cambiante para cada cultura material y para cada localización climática, pero sustancialmente idénticos a sí mismos." Ábalos, 2012 un recurso para poder salir de la tendencia compulsiva por la significación o el archivismo contemporáneo y, a su vez, luchar contra el simplismo de las demoliciones. Es también un mecanismo para devaluar culturalmente la construcción y volver a construir en torno a ella una nueva escala de valores culturales. Como ha indicado Arnoldo Rivkin, la categoría "economía” se dilata para caracterizar la arquitectura de Lacaton \& Vassal en una doble acepción que amplía su alcance:

"En un sentido cuantitativo, la economía expresa una maximización de la superficie construida en relación al capital invertido; en un sentido cualitativo, la economía da cuenta de la posibilidad de una mayor intensidad de espacio, un mayor grado de plenitud y confort. El encadenamiento de estos dos aspectos es lo que permite singularizar la obra de Lacaton \& Vassal" 98

\subsubsection{Economía cualitativa}

Las aproximaciones a la economía cualitativa son una constante en la trayectoria profesional de Lacaton \& Vassal: los incrementos de superficie, los ahorros presupuestarios y los balances medioambientales aparecen reiteradamente en sus textos. No importa dónde, no importa para quién. Los proyectos comparten desde el origen unos principios comunes y universales. ${ }^{99}$ Es una conducta global y táctica que proporciona coherencia a toda su obra. Una actitud que no se debería confundir con un estilo, con un modo de hacer estético a priori-que sin duda se acaba por construir con la acumulación de proyectos-, sino con un plan que supera la escala de los proyectos concretos. La suya no es una arquitectura de detalles, que los hay, ni una arquitectura de composición sino una arquitectura de argumentos, de pragmatismo y de totalidad. Y sin embargo es al mismo tiempo sensible con lo local y cuidadosa con sus vecinos, profundamente respetuosa con los asuntos de la vida y el placer. Las renuncias de la arquitectura se convierten, en esta lógica económica, en las ganancias de los habitantes en un sentido amplio. Así lo planteaban en 1993 en la casa Latapie y diecisiete años después en las viviendas sociales en Trignac, donde el presupuesto iba casi íntegramente dirigido a maximizar la superficie disponible para los propietarios. En la Casa de Cap Ferret los beneficios están generosamente 

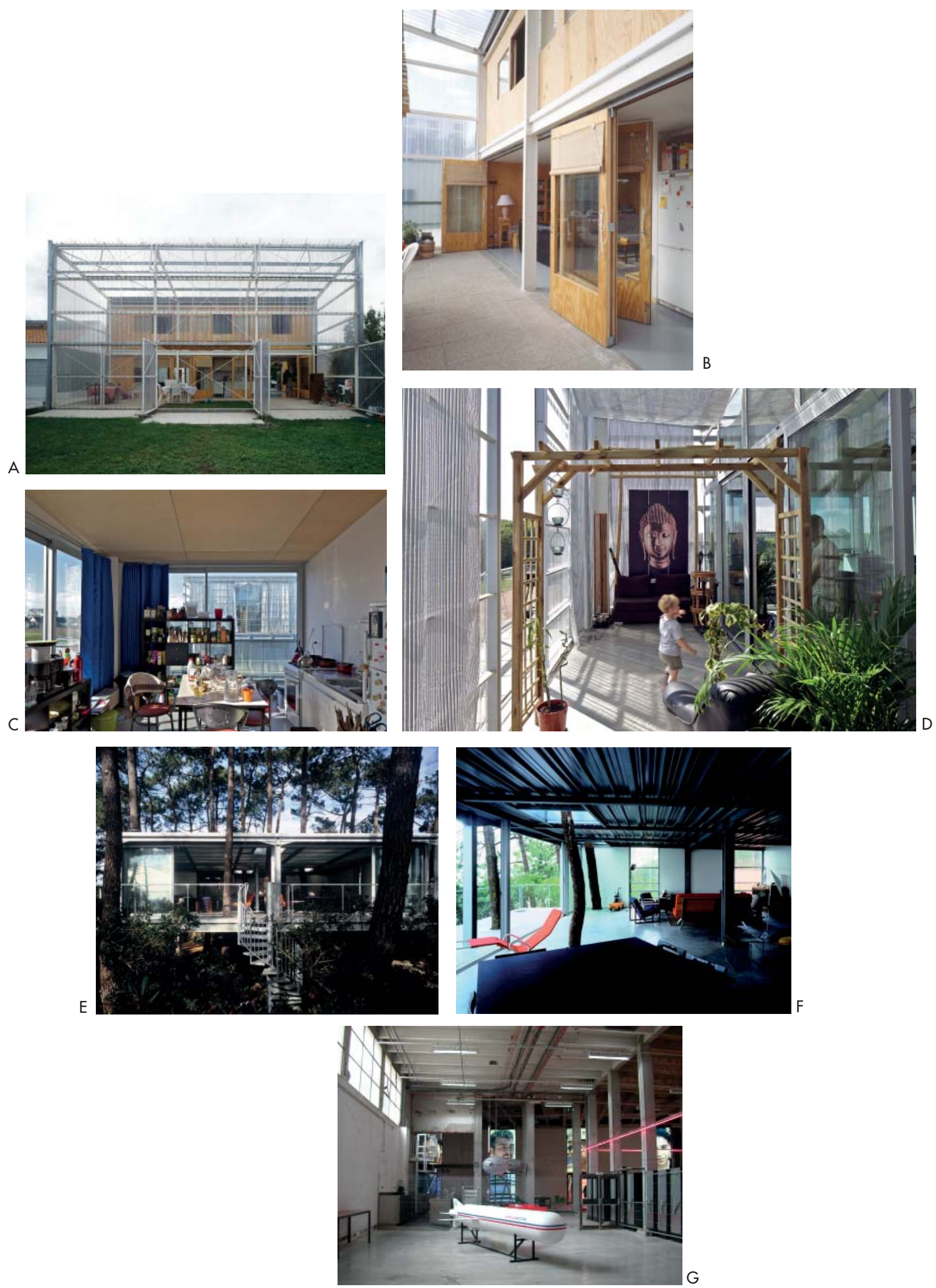
A-B. Lacaton \& Vassal. Maison Latapie, Floirac. (1993).

C-D. Lacaton \& Vassal. Viviendas Trignac, Floirac (2000).

E-F. Lacaton \& Vassal. Porche de Maison Cap Ferret Floirac. (1998).

G. Lacaton \& Vassal. Palais de Tokyo, París. (2002)

100. Goulet, 2010: 132
101. Anne Lacaton en respuesta a la pregunta
¿Qué es el lujo? Druot, Lacaton \& Vassal, 2007: 40 compartidos, los "alardes" estructurales se negocian para satisfacer de manera equivalente a los habitantes en su deseo de ver el mar y a los árboles el de sobrevivir. O el caso del Palais de Tokyo en el que la inversión para la transformación arquitectónica es mínima y sin embargo las ganancias en espacio son máximas para gestores, comisarios y artistas.

Como reflejo de esa economía cualitativa nos aproximaremos a un término que utilizan con asiduidad Druot, Lacaton \&Vassal: el lujo. Esa expresión que habitualmente sirve para designar todo aquello que excede de lo necesario y que sobrepasa los medios habituales es reivindicada como la principal aportación de su arquitectura. El lujo sería, bajo su perspectiva, una forma de alterar las jerarquías para conseguir lo excepcional y lo deseado. "El lujo es aquello que supera las expectativas iniciales" dirá Anne Lacaton ${ }^{100}$

Si la vivienda de los conjuntos habitacionales estaba asociada desde su origen al habitar mínimo como respuesta a la acuciante demanda de vivienda en las décadas posteriores a la postguerra, el lenguaje que propone Plus permite transformar el ideario subyacente. El término lujo parece en sí una contradicción comparado con el material con el que arranca, la vivienda social, y con las restricciones que se marcan, el control presupuestario. La noción del lujo evidentemente no tiene que ver con materiales caros, o excentricidades elitistas. El lujo es un potencial de lo construido:

"La noción del lujo es ofrecer un plus cuando se aborda una situación concreta. Es decir, revelar y permitir llevar a cabo lo inesperado, un plus apenas imaginable para los demás y, en ningún caso, para uno mismo. No es una idea estática. Permite abordar con libertad la modificación de una circunstancia dada”"101

El lujo es el término elegido para redescribir las propiedades de lo construido asociadas al disfrute y apropiación de sus habitantes. Es hacer insólito lo convencional a través del diseño y proporcionar una nueva belleza para los obsoletos conjuntos habitacionales. El juego consiste en imaginar lo que la genética de lo existente puede llegar a ser y conseguir mediante acciones estratégicas las máximas plusvalías de la inversión. En los bloques de los sesenta los arquitectos encuentran la posibilidad de tener grandes espacios, transparencias, gran altura, vistas despejadas, espacios intersticiales o zonas 


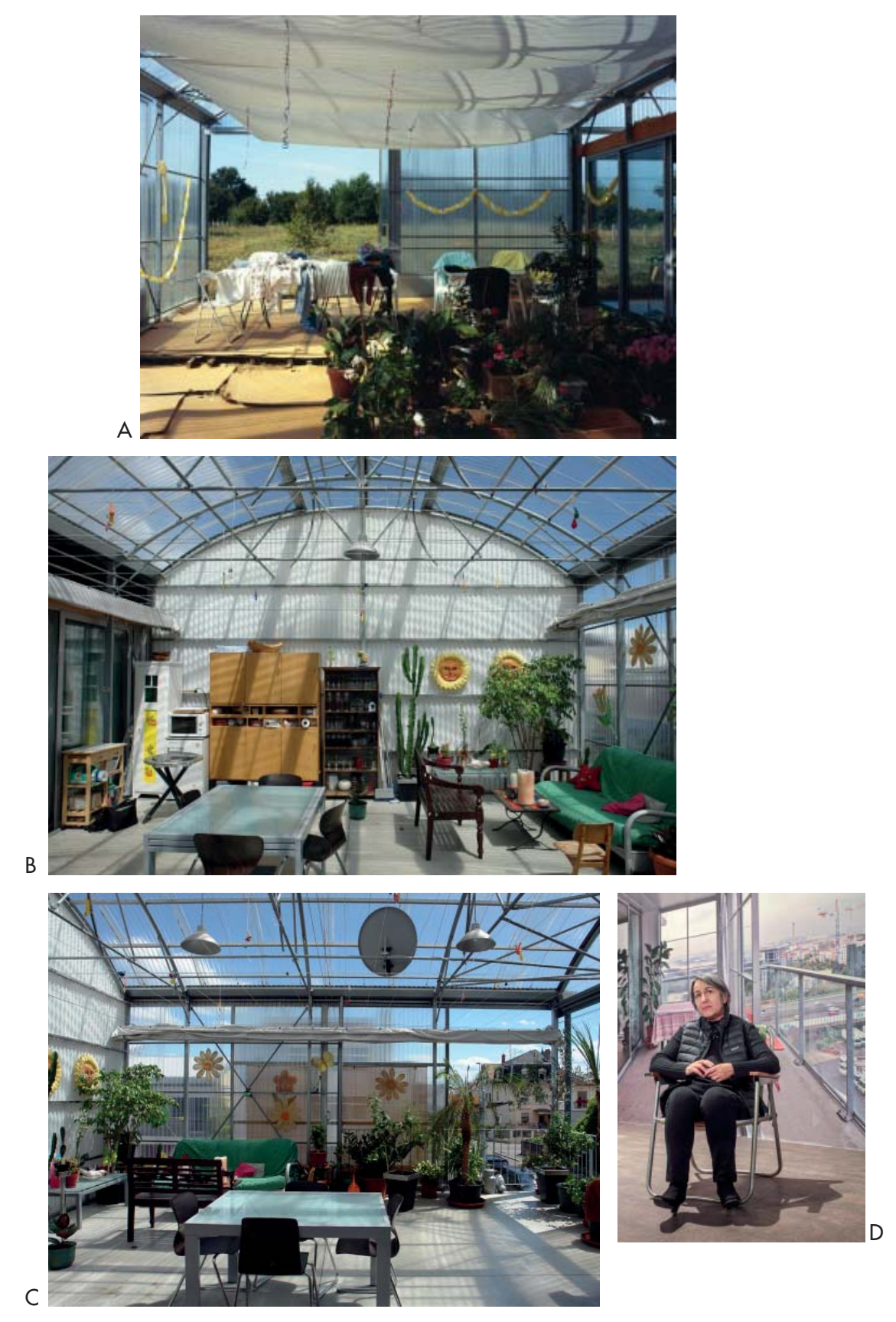


A. Lacaton \& Vassal. Casa Coutras, Francia (2000).

B-C. Lacaton \& Vassal. Vivienda social en Mulhouse, Francia (2005).

D. Anne Lacaton en Tour Bois le Prêtre Transformation of an Apartment Block, exposición del DAM Deutsches Architekturmuseum Frankfurt (2013). amplias. Los edificios pueden ser exprimidos a través de la economía y dilatados a través de la inteligencia.

Es habitual escuchar en las entrevistas como, para Anne Lacaton y JeanPhilippe Vassal, los metros cuadrados definen la posibilidad de la libertad, el lujo más preciado. Desde sus primeras obras como la Casa Latapie, ganar superficie de actividad para los habitantes por el mínimo precio debía ser la gran conquista, su gran hallazgo. En palabras de Anne Lacaton:

"El lujo está ligado a la libertad de uso y a un alto nivel de posibilidades con menos restricciones, con el no tener límites a tu imaginación y deseos y, desde luego, no está ligado al coste.”

Pero no nos interesa aquí tanto insistir en los medios económicos con los que se construye, ni entrar en los caminos más trillados de la apropiación y utilización de sistemas estandarizados y asequibles, como el reiterativo de los invernaderos, para producir arquitectura. Sino más bien incidir en el origen de esa decisión y el resultado de su hallazgo. No es la economía por la economía lo que excita nuestra mente cuando vemos su trabajo, sino otro tipo de mecanismos que en realidad tienen que ver con lo que podría entenderse como un desplazamiento de imaginarios.

\subsubsection{Desplazamiento de imaginarios}

Hablando de la obra de Lacaton \& Vassal, Juan Herreros generalizaba:

“El arquitecto está siempre proyectando e imaginando segundas oportunidades para todo lo que ve, ya sea un paisaje, un edificio, una ciudad o un lugar vacío. El recurso de la apropiación y la redescripción de lo que nos rodea es lo que da valor a la forma de contemplar el mundo con ojos de arquitecto, porque constituye su más poderoso protocolo de anclaje a su tiempo y a su cultura." 102

Del análisis de esta afirmación obtenemos una interpretación evidente: todo arquitecto proyecta futuros en los lugares que observa. Como dice Herreros, ya sea un paisaje, un edificio, una ciudad o un lugar vacío, 

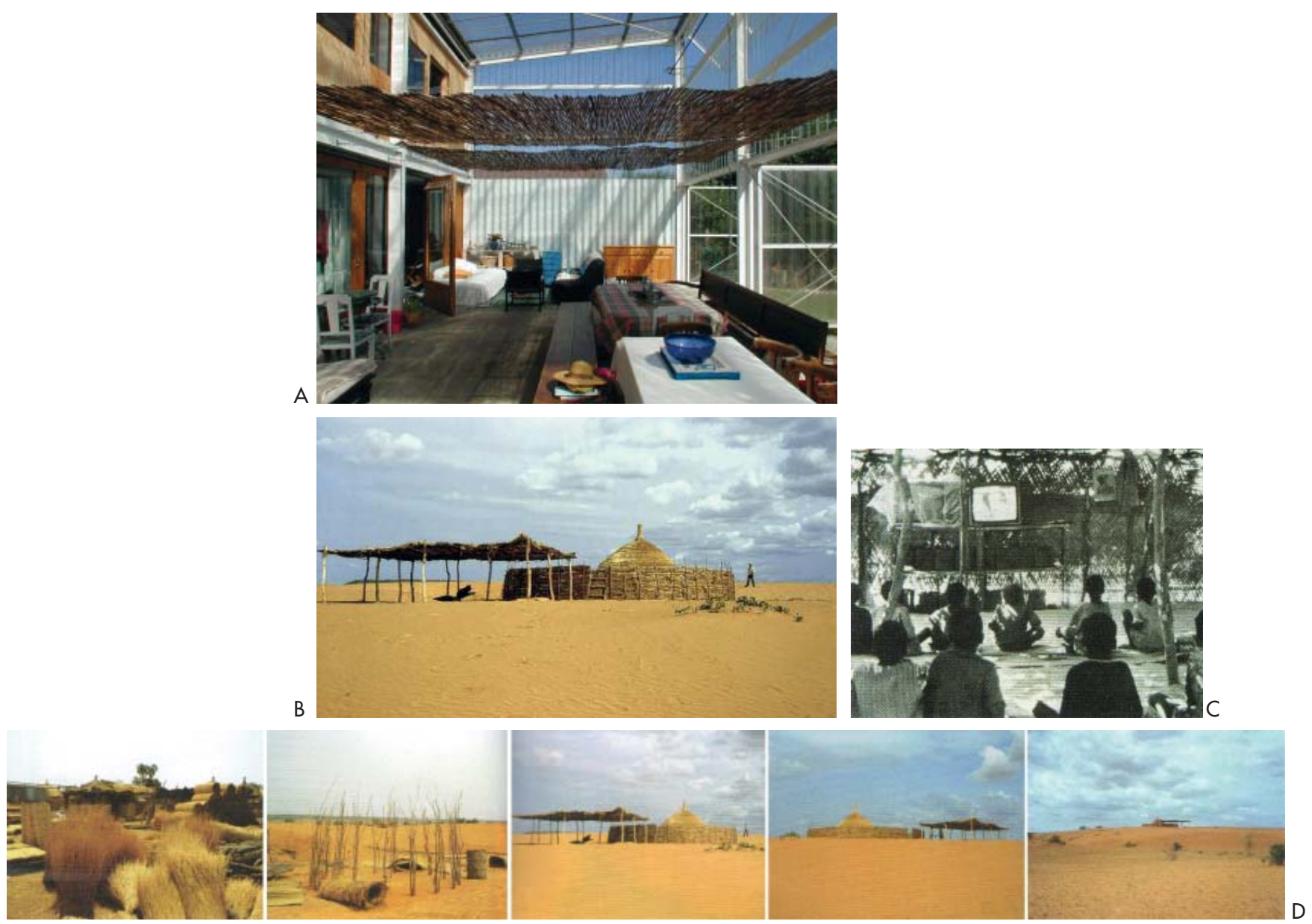
A. Lacaton \& Vassal. Maison Latapie, Floirac (1993).

B-D. Lacaton \& Vassal. Choza de paja, Niamey, 1984. todos son territorios para la acción. La óptica del arquitecto incorpora el deseo de transformar lo físico. Pero cabría ampliar aún más el sentido de la cita, podríamos decir que el arquitecto proyecta e imagina segundas oportunidades también para lo que recuerda, para los archivos que custodia y aprecia. En definitiva, el arquitecto quiere devolver a la vida el mundo de lo que ha visto y ha observado con afecto. Así ha ocurrido tantas veces, desde el Renacimiento, al Movimiento Moderno, desde el Rococó a las Vanguardias. El desplazamiento de imaginarios distantes es un mecanismo de innovación -y afirmaría, si no se exigiera aquí la distancia y la objetividad del investigador, que es el más poderoso y el más excitante-. El proceso se podría definir como el uso intencionado de una representación simbólica o de una mitología arquitectónica distante en el tiempo o el espacio que es ubicada en un nuevo contexto en el que su singularidad, exotismo o diferencia puede ser advertida.

Este es el mecanismo proyectual que realmente está movilizando las propuestas en Plus y no la "economía cualitativa", que en realidad estaría preparando el territorio, desmontando prejuicios o incluso podríamos decir que está distrayendo de la verdadera acción arquitectónica. Parecería que es el fin en sí mismo cuando en realidad es un medio para precisamente ejecutar el proyecto. No quiero decir con esto que exista un plan oculto, no es una acción maliciosa o de engaño. Más bien parece una forma de conquistar la libertad para el proyecto. Tenemos que recordar otra vez que el propósito del informe presentado al Ministerio de Cultura no era otro que desmontar el andamiaje con el que se había condenado a los conjuntos habitacionales. Conquistar la libertad pasaba por la suspensión del juicio como ya hemos visto y el cambio de las jerarquías de valor. A tenor de los resultados no parece haber sido una mala estrategia.

Revisando el manifiesto bajo esta óptica, el desplazamiento de imaginarios se hace evidente desde la primera página. No tanto a través del texto sino a través de las ilustrativas imágenes que lo acompañan. Aunque en la maquetación definitiva del libro las imágenes han quedado relegadas a un tamaño menor, en las esquinas, no era así en el informe original cuya presencia era a página completa y precedían al texto, dando constancia del valor que tienen dentro de la argumentación. El conjunto al que nos referimos está formado por dos imágenes que muestran el antes y el después de una habitación genérica de 

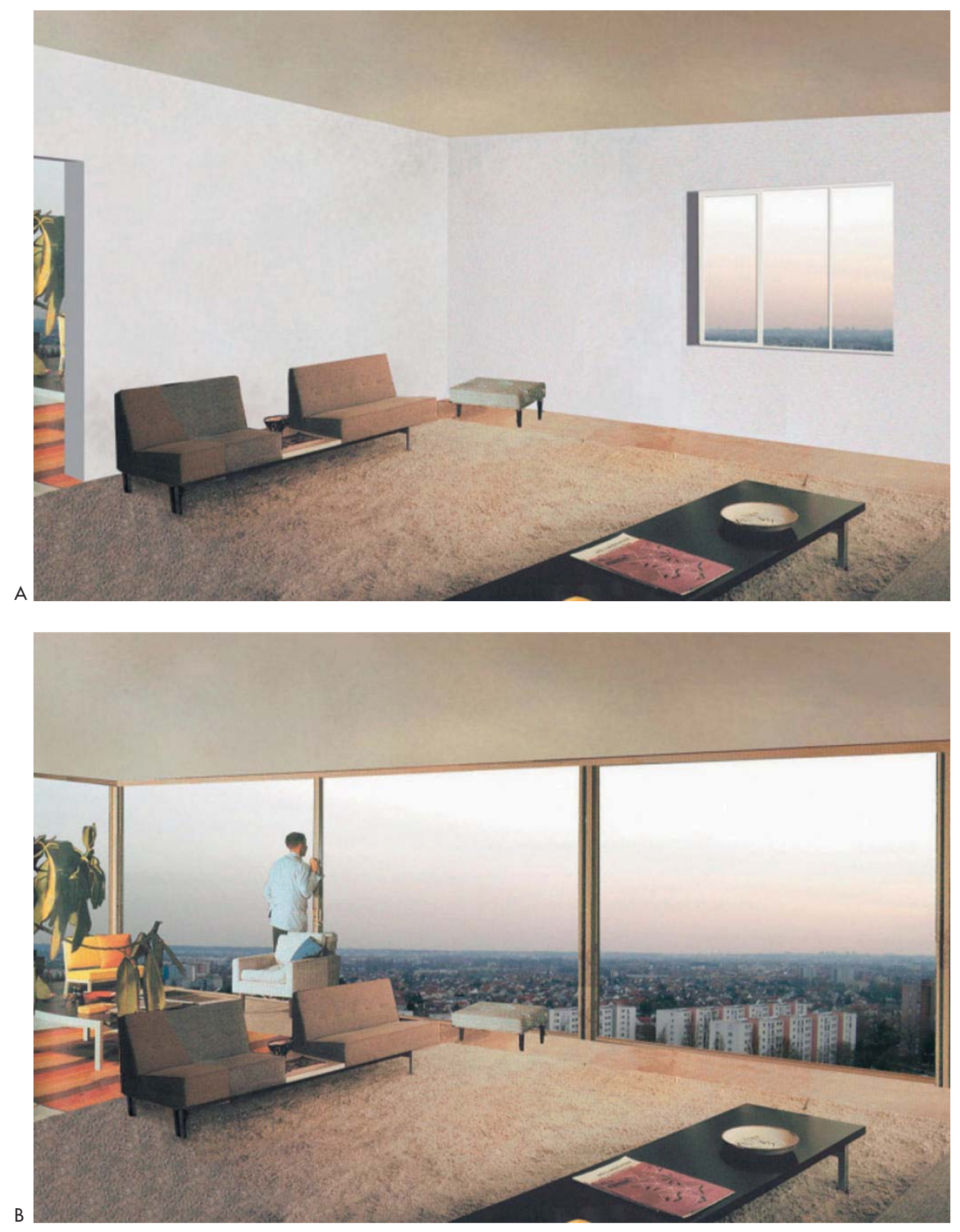
A-B. Druot Architecture y Lacaton \& Vassal. Montaje para la reforma del edificio residencial Bois Le Prêtre, París (2013) una torre genérica. La técnica utilizada para la construcción de la imagen es el montaje. Todo ha sido dispuesto por los arquitectos para construir un discurso.

La primera imagen muestra un salón, pocos muebles, ninguna persona. Hay algo triste o melancólico en ella. No hay sombras, y por la única ventana que existe se intuye apenas un horizonte construido y la luz ambigua de un atardecer (o de un amanecer). A la izquierda, casi fuera del fotomontaje, el paso de una puerta nos deja entrever otra habitación, una que parece más alegre. Los muebles son algo viejos, las paredes están sorprendentemente vacías.

La segunda imagen es, por contraste, seductora. Ya no hay tabiques interiores, han desaparecido. Se ha duplicado el espacio. La fachada también se ha evaporado, ahora es una enorme vidriera de suelo a techo. El mobiliario no ha cambiado, y sin embargo parece mejor. Ya hay una persona, está de espaladas, lleva un traje, mira al exterior. Unas vistas fantásticas, en altura, sobre la ciudad. Ahora casi tenderíamos a pensar que es un amanecer y que estamos viendo la llegada al hogar de un dandy que disfruta de las vistas de la ciudad en la tranquilidad de la mañana. La imagen es bella, evoca una nostalgia hedonista. Los suaves degradados y la quietud reflexiva del personaje nos devuelven un Edward Hopper hecho con recortes fotográficos. Sin duda sentimos las ganas de ocupar su lugar, querríamos estar allí. Esto ya lo hemos pensado otras veces, porque ya conocíamos ese espacio, lo habíamos visto antes, muchas veces. Cualquier arquitecto interesado podría reconocerla, es una imagen mítica. Sabemos que lo que estamos viendo es una apropiación de una foto de Julius Shulman. En realidad, comparada con la imagen original, la foto no es tan parecida pero en nuestra cabeza no puede dejar de resonar la fotografía de Shulman cuando vemos la versión alterada de Plus. Vibran las cuerdas de la memoria y nos gusta la melodía.

La imagen original, a la que hace referencia Plus, es el interior de la Case Study House \#22 diseñada por el arquitecto Pierre Koenig en 1960. Construida sobre una colina de Los Ángeles, es una arquitectura sencilla de acero y vidrio. La imagen forma parte de un conjunto de fotos de la casa en las que se suceden relajadas escenas de sofisticada domésticidad que tienen como decorado final la extensión infinita de la ciudad. Las imágenes son 

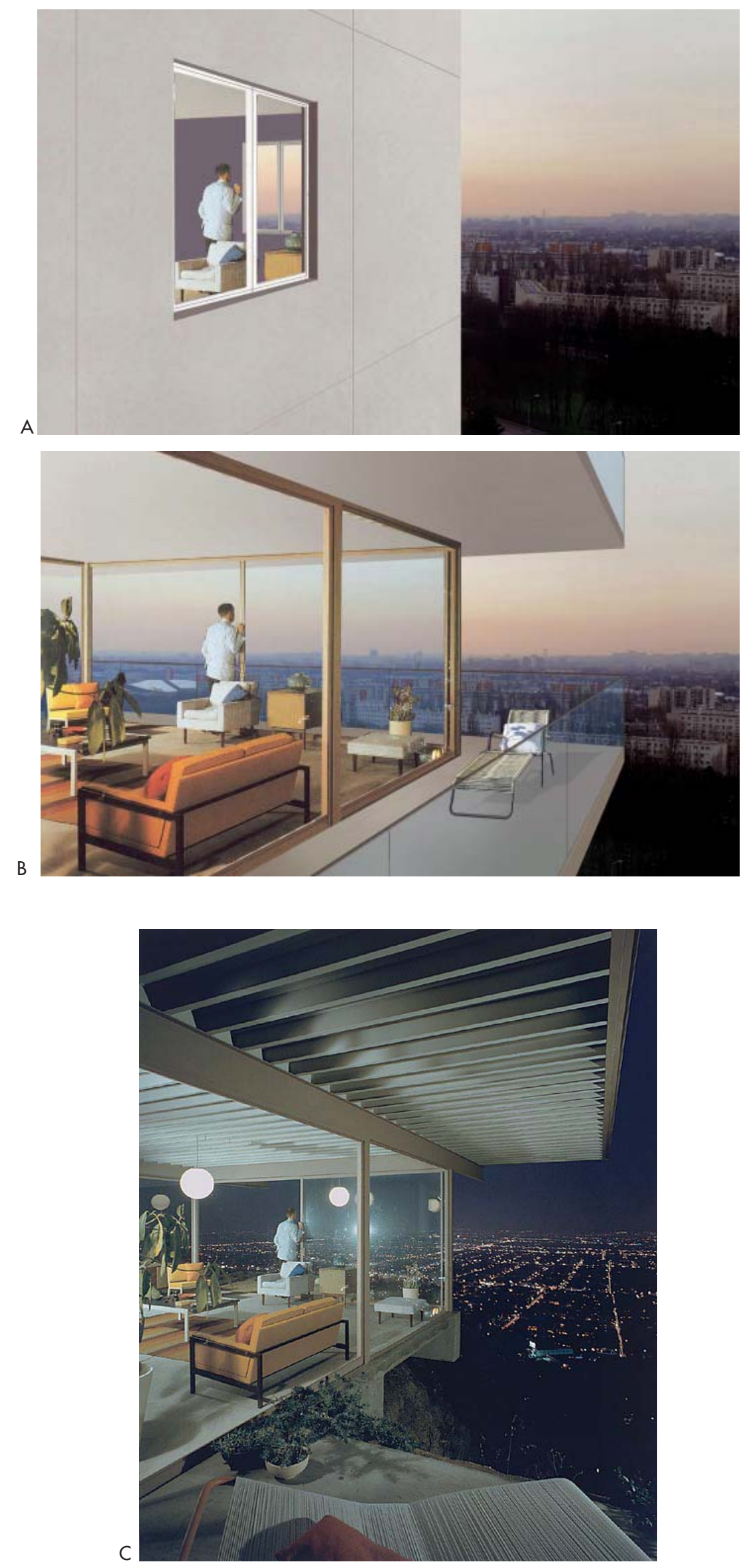
A-B. Druot Architecture y Lacaton \& Vassal. Montaje para la reforma del edificio residencial Bois Le Prêtre, París (2013).

C. Pierre Koenig. Stahl House. Case Study House n. 22 (1960).
103. Es conocida la predisposición de Shulman a reconstruir los escenarios de sus fotografías mediante una edición espacial que los más puristas considerarían engañosa. Se pueden ver estas manipulaciones en Alexander, 2010. bellas y evocadoras. Las fotos son, literalmente ${ }^{103}$, la construcción de una escenografía para un modo de vida. Shulman hizo más por la arquitectura moderna de Los Ángeles que casi ninguno de los arquitectos que fotografió. Los edificios son excepcionalmente básicos. De lo que vemos poco pertenece a la arquitectura y sin embargo esta lo permite todo: la presencia relajada del hombre mirando, los muebles bajos, la transparencia, el horizonte. La experiencia que construye la fotografía es profundamente atractiva, referencia de toda una cultura. Un epítome de la arquitectura de la buena vida y del placer doméstico. Es una de las manifestaciones más logradas de una mitología arquitectónica, de un imaginario compartido. En Plus recurren a ese poder movilizador y a esas energía latente. El objetivo no es otro que desplazar el imaginario de la California moderna al territorio de la vivienda social europea. El contraste en lo intelectual y en lo material no puede parecer mayor y sin embargo es tan sugerente como rico en lecturas. No solo revisa los principios del movimiento moderno sino que afloran muchos de los prejuicios incrustados en él.

A lo largo del libro hay varios montajes en los que se vuelve a recurrir a esta imagen mítica. El ejercicio de ensamblaje se hace también para las vistas desde el exterior. Otra vez con un antes y un después de la trasformación. En la primera imagen vemos el interior desde una pequeña ventana abierta en la fachada, nosotros estamos volando. En una secuencia de cambios la torre se va transformando en una sucesión de Koenig Houses apiladas. Voladizo sobre voladizo, casa sobre casa, el mecanismo vuelve a ser el mismo, mostrar como la anodina torre puede ser transformada en la casa que siempre habías deseado. La casa de Los Ángeles tele-transportada a París, Niza, Montpelier.... en definitiva, una casa generada por desplazamiento.

Druot, Lacaton \& Vassal se aprovechan de la capacidad evocadora de las imágenes de las Case Study Houses. Jean-Philippe Vassal lo describe así:

"Tratamos, habitualmente, de encontrar referencias bastante sencillas y trabajar con ellas, por ejemplo, las Case Study Houses. Nos interesan porque constituyen una experiencia extraordinaria de habitar generada por una arquitectura sencilla. Las vemos como un material con el que comenzar a producir apartamentos superpuestos con las mismas condiciones.- luego, para colocarlos en altura 

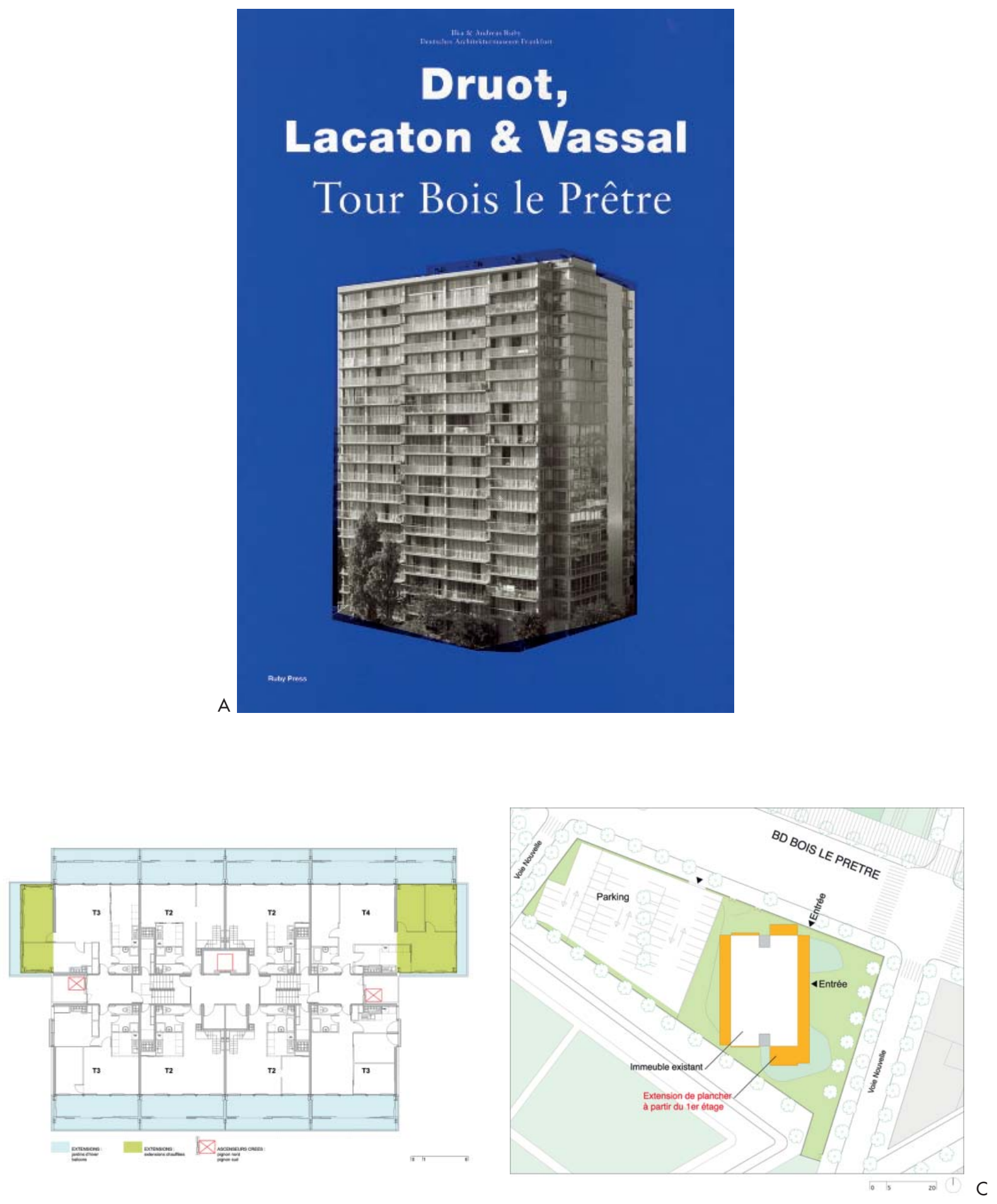
A. Druot, Lacaton \& Vassal. Portada de Tour Bois Le Prêtre (2012).

B. Druot Architecture y Lacaton \& Vassal. Bois Le Prêtre (2012).Planta tipo.

C. Druot Architecture y Lacaton \& Vassal. Bois Le Prêtre (2012). Planta de situación. Boulevard Bois Le Prêtre, París. se necesita una estructura que los soporte a diferentes niveles-. Básicamente, creamos una situación para una serie de Case Study Houses tratando de repetir la misma calidad original." ${ }^{104}$

Haremos ahora el trayecto comparativo en la dirección inversa, tomemos su montaje y, en lugar de enfrentarlo a sus orígenes- las imágenes de Shulman-, confrontémoslo con un resultado construido. Para ello visitaremos el proyecto de transformación de la torre de Bois-le-Prêtre en París que aparece en el libro como demostración. Construida en 1959 por el arquitecto Raymond López, es un edificio con más de 50 metros de altura en las inmediaciones del bulevar periférico al norte de la ciudad. Cuenta con 96 apartamentos alojados en un sistema muros y forjados contrapeados de hormigón. La construcción original había sido alterada en 1990 modificando la mayor parte de sus virtudes: se redujo el tamaño de los huecos, se eliminaron los balcones y se clausuró el espacio entre pilotis de planta baja. Lacaton \& Vassal propusieron una acción generosa de transformación, que consistía fundamentalmente en aplicar la imagen mítica de Shulman mediante la adición de un espacio adyacente a la fachada por delante de los forjados originales.

Con motivo de una exposición en el Deutsches Arkitekturmuseum de Frankfurt en 2012, Ilka y Andreas Ruby publicaron un ambicioso catálogo que recogía la experiencia completa de la obra de Bois-le-Prêtre. El libro, de gran formato, y excepcionalmente editado recoge tanto el resultado de la obra como la acogida por parte de los habitantes. La publicación contiene numerosas imágenes a página completa de los apartamentos habitados acompañadas de breves entrevistas en las que relatan su experiencia después de la transformación. El interés en eta publicación reside en la posibilidad de comparar las expectativas de partida y la apropiación del espacio por parte de los inquilinos.

Druot, Lacaton \& Vassal no renuncian a los montajes, estos vuelven a aparecer a página completa al principio de la publicación. Sin embargo, la diferencia con lo construido es más que notable. En las fotos la luz es brumosa, parece nublado. No existe una transparencia cristalina sino más bien una superposición de materiales algo turbia. El espacio es generoso y los muebles han colonizado todo el lugar. La vivienda es muy diferente a 

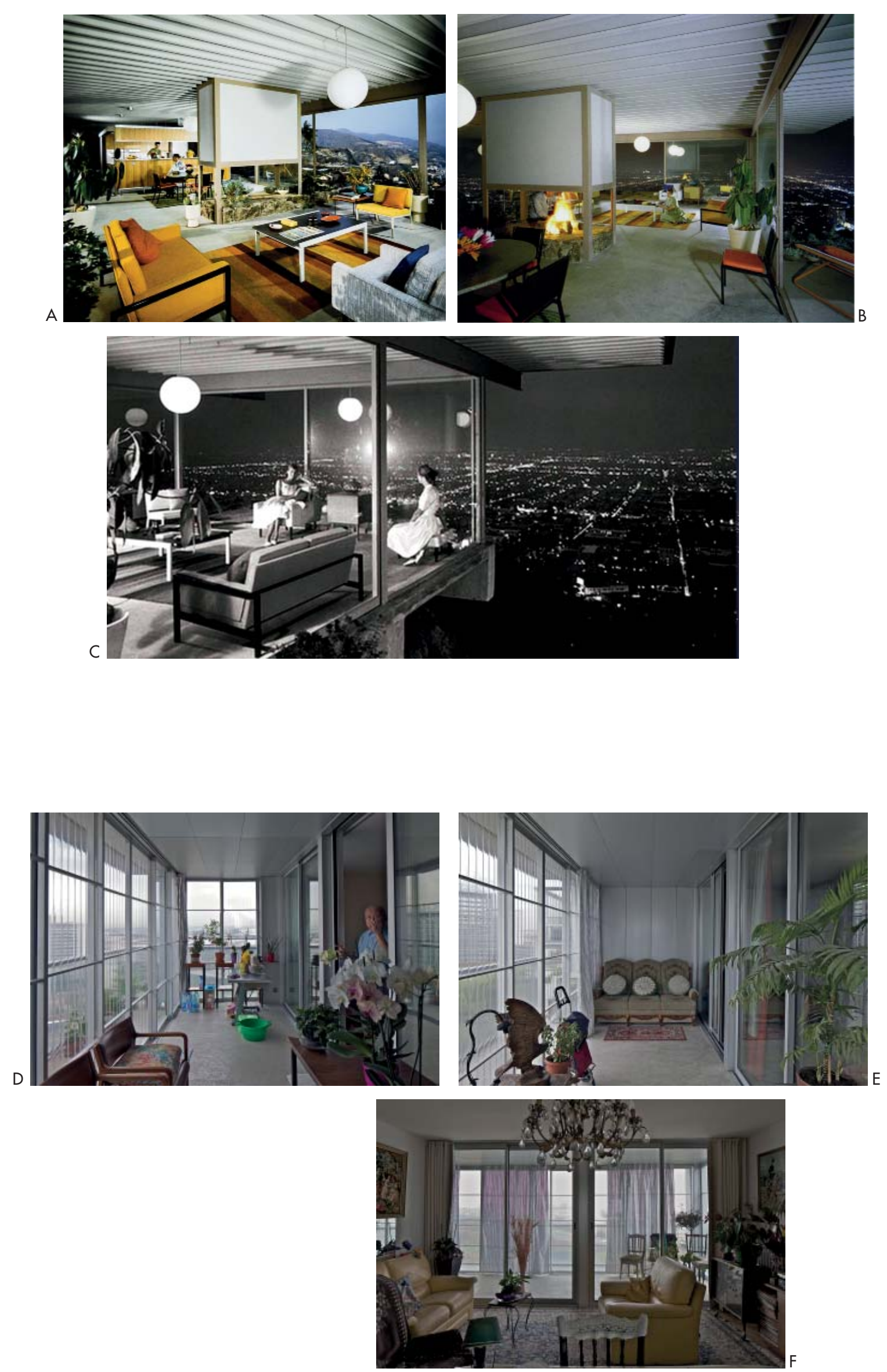
A-C. Pierre Koenig. Stahl House. Case Study House n. 22 (1960).

D-F. Druot Architecture y Lacaton \& Vassal. Bois Le Prêtre (2012). Fotografías del interior.

105. El documental HLM, Habitations Légèrement Modifiées dirigido por el arquitecto Guillaume Meigneux muestra la forma en la que conviven obreros y habitantes durante el proceso de construcción. las que veíamos en las Case Study Houses, no queda nada del hedonismo original, por el contrario, hay algo costumbrista en el ambiente. No son ya los interiores imaginados para volver de madrugada a ver el amanecer ni el lugar ideado para saborear unos dry martinis. Más bien son interiores que recuerdan a bricolaje de domingo por la mañana, a conversación con los abuelos o a encuentros caóticos a la hora de la comida. Se producen simpáticas coexistencias: muebles de tosco art decó o de reminiscencia balinesa conviven con superéxitos de IKEA e imitaciones Biedermeier. Todo adquiere un aspecto algo irreal entre los desvaídos efectos del policarbonato ondulado y el gris ultra-neutro del hormigón. Los inquilinos, en las entrevistas, hablan de la transformación con entusiasmo y remarcan lo mucho que disfrutan de los nuevos espacios; cuentan lo que han ganado, como se ha transformado su vida y de la sorpresa de los hallazgos: ahora veo la Torre Eiffel, ya no me importa pasar un día entero sin salir del salón, la luz es lo que más ha cambiado, etc.

Cuando leemos la interpretación por parte de Druot, Lacaton \& Vassal de estas fotografías podemos entrever una excitada satisfacción-y quién los conozca sabrá que no es su estado habitual-. El resultado, aunque lejos de las imágenes que habían imaginado, puede leerse como un éxito. La vivienda cuenta con la luz, las vistas, lo diáfano esperado y al mismo tiempo mantiene los afectos, los modos de vida, y la huella de sus habitantes. Uno de los logros de esta obra fue realizar la alteración de la fachada sin tener que desalojar a sus habitantes. ${ }^{105}$ Eso ha hecho que las nuevas áreas de la casa se colonicen por extensión desde la parte original. La obra consolida el sentido de pertenencia del hogar.

Las imágenes de la propuesta construida muestran que lo que prometían los fotomontajes no se ha logrado, tampoco se ha perdido. Podríamos decir que se han priorizado otros aspectos. Se incorporan las dobles capas en las terrazas como reguladores térmicos y se recurre al policarbonato más ligero y económico para la envolvente exterior. Se renuncia a la trasparencia total del movimiento moderno para situarse en un paradigma termodinámico. Tampoco el edificio original les permitirá cumplir su promesa californiana. La estructura original condicionará organización y vistas. Estos, como otros ejemplos, hacen que inevitablemente la aplicación del imaginario desplazado requiera un ajuste. Se hace explicita la distancia insalvable entre la 

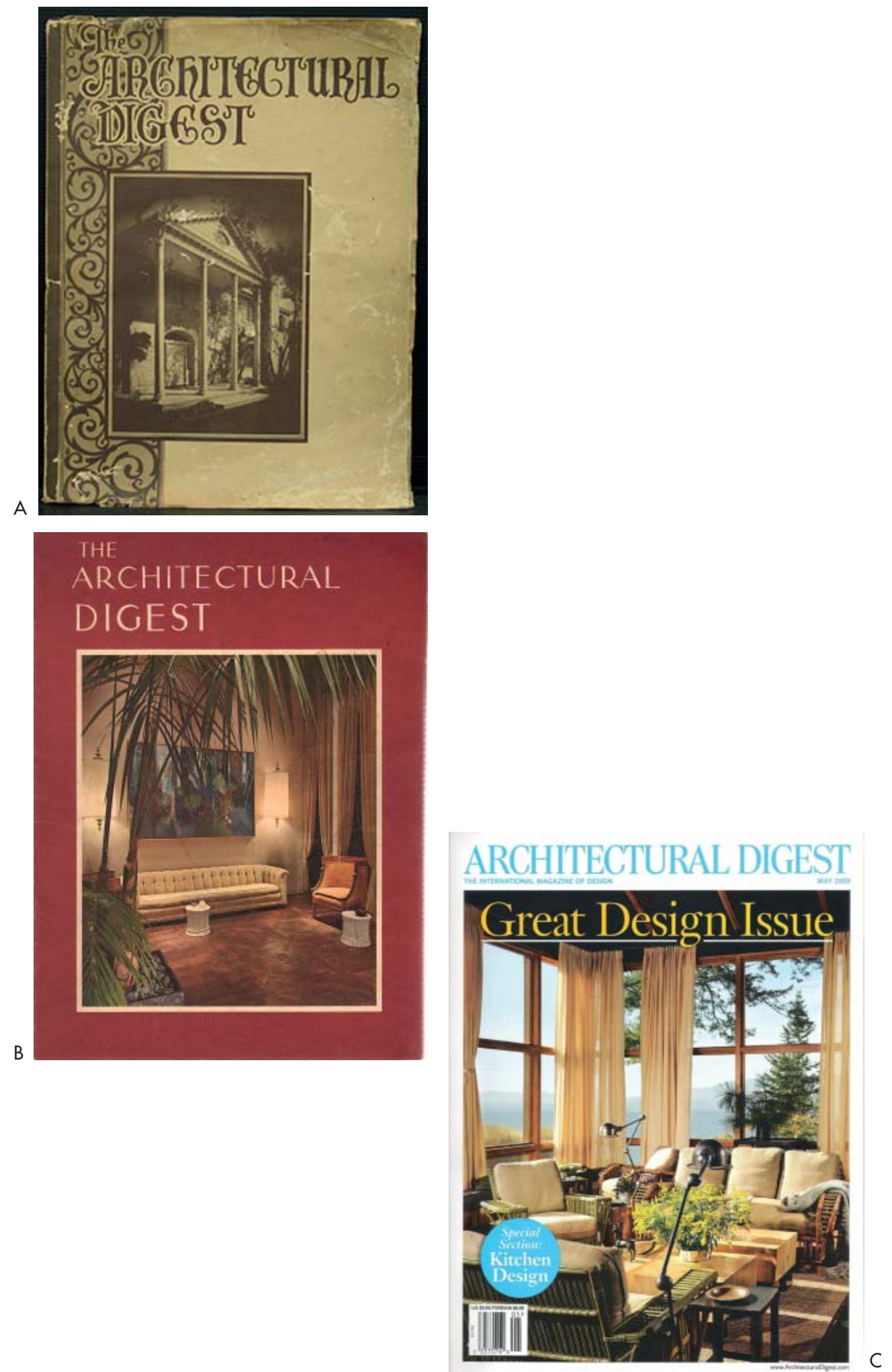
A. Portada de The Architectural Digest. Número 1, 1920.

B. Portada de The Architectural Digest. 1965

C. Portada de The Architectural Digest. Abril, 2009. mitología del proyecto y la realidad. Ese salto, esa fractura entre expectativa y lo construido produce la innovación y la belleza. En realidad lo que percibimos es que existe en la materia una resistencia a la transformación. Las arquitecturas existentes son tenaces pero no de una forma homogénea $\mathrm{O}$ constante sino que está jerarquizada según un sistema estratificado.

\subsection{ESTRATIFICACIÓN DEL CAMBIO}

La revista Architectural Digest nació en 1920 con el nombre The Architectural Digest: A Pictorial Digest of California's Best Architecture, en ella se mostraban imágenes de interiores, exteriores y planos de casas realizadas en California. En origen era una revista de arquitectura, como muchas otras, centrada en proyectos y obras de nueva planta. Gradualmente su interés fue cambiando hacia las reformas y la arquitectura de interiores. Aunque la mayor parte de sus lectores soñaran con hacerse una nueva casa la evidencia era que solo tenían la oportunidad y el dinero de rehacer parcialmente sus hogares. Para 1963, el subtítulo de la revista había sido sustituido por A Pictorial Digest of Outstanding Architecture, Interior Design, and Landscaping y ya en 1974 adquirió el definitivo The Connoisseur's Magazine of Fine Interior Design. La razón fundamental del cambio se debió a la migración de los anunciantes. La decisión fue interesada, en la decoración y el interiorismo es donde estaba la acción, donde se "movía la pasta". La revista había dejado de lado la arquitectura porque se había dado cuenta de que la gente casi nunca se construía su casa pero si reformaban sus baños, remplazaban sus cocinas o cambiaban sus salones. Deseaban nuevas vidas, pero no podían empezar de cero, no podían cambiarlo todo. La filosofía podría ser: si la gente tiene dinero arreglará sus casas, como mínimo para resolver su frustración con el edificio, como máximo para mostrar su riqueza. Los edificios cambian y crecen, es una regla universal, una condición irrenunciable, pero cuando cambian no lo hacen de forma homogénea. 


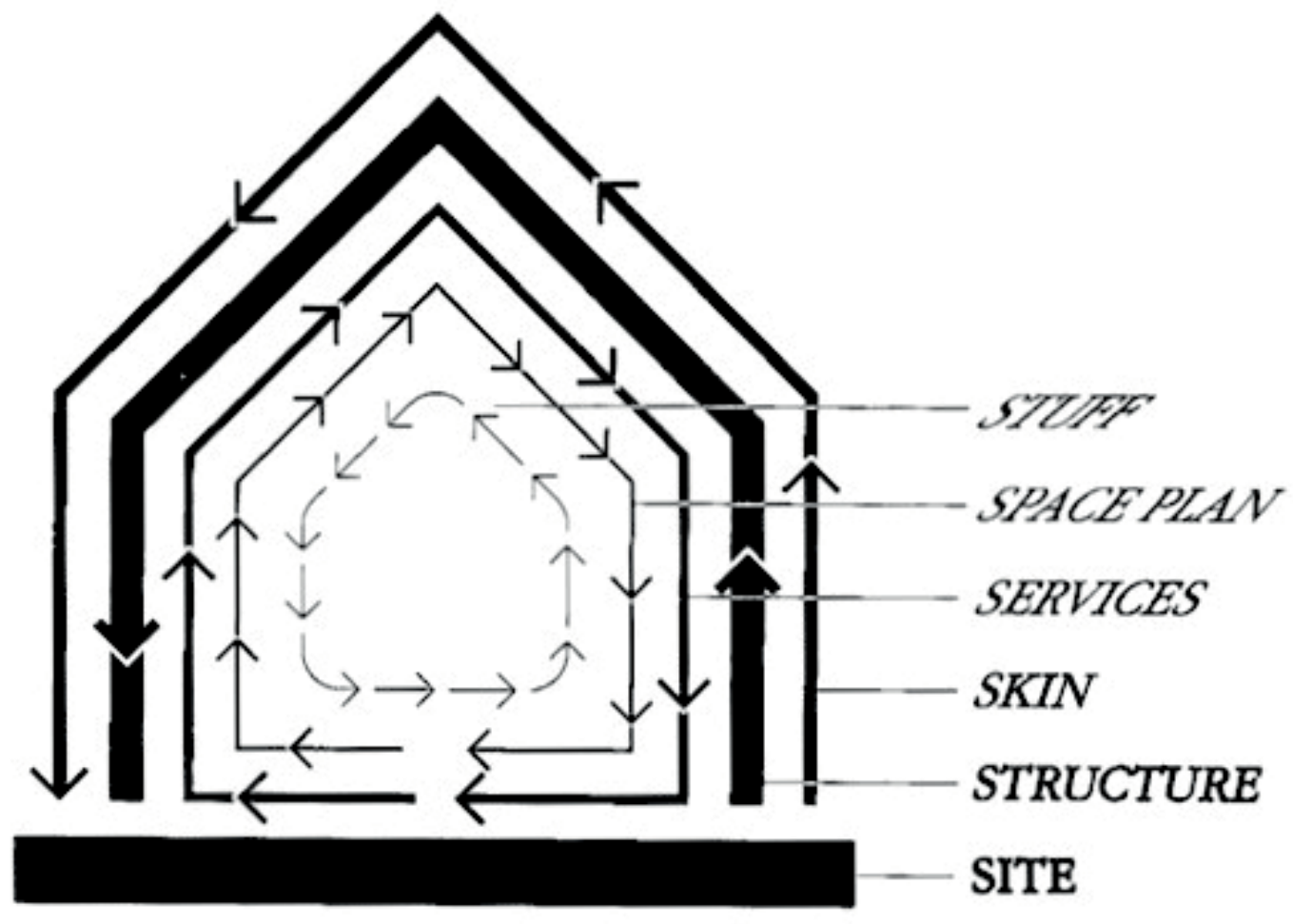

SHEARING LAYERS OF CHANGE. Because of the different rates of change of its components, a building is always tearing itself apart. 
A. Stewart Brand. Diagrama Shearing layers of change (1994).

\subsubsection{Shearing Layers of Change}

Lo que se pone en evidencia a través del ejemplo de las revistas de decoración es que las actuaciones sobre lo construido tienen diferente intensidad y periodicidad dependiendo de los elementos a los que afectan. No todos se actualizan con la misma frecuencia ni ofrecen las mismas resistencias. Stewart Brand, en su libro How Buildings Learn ${ }^{106}$, afirma que existe una forma de entender la arquitectura más allá de la unicidad y coherencia con la que se la describe desde la disciplina. Brand ${ }^{107}$, que proviene del mundo de la biología y no posee los prejuicios heredados por los arquitectos, es capaz de realizar un análisis lúcido sobre las arquitecturas ordinarias basadas en sus modos de transformación. Su libro es especialmente relevante porque estudia la arquitectura explícitamente a través de su crecimiento en lugar que desde su imagen o su significado. Eso le permite abarcar toda la arquitectura por igual y evaluarla desde su capacidad para adaptarse o ser mantenida. El tiempo que le interesa no es el del legado del pasado sino el de la degradación y la transformación a futuro. Su interpretación asume que no existe la unidad que llamamos edificio sino que por el contrario este es un conjunto de organizaciones con diferentes temporalidades. Lo edificado es una suma de capas con diferente resistencia al cambio. Lo que Architectural Digest, como otras revistas de decoración, estarían visibilizando son las condiciones de esa temporalidad, no solo la más evidente de los programas u actividades de la casa, sino también las posibilidades y facilidad con las que se puede operar en esas arquitecturas ordinarias. Si miramos a las arquitecturas representadas en los archivos de la cultura existe un pegamento que solidifica el edificio en una unidad, una ligadura que llamamos significación y que hace que veamos la arquitectura como un todo inseparable en el que nada sobra o nada falta -quizá la frase más común utilizada en las escuelas de arquitectura para justificar la calidad de un edificio-. Sin embargo las arquitecturas ordinarias no tienen ese aglutinante: se desmiembran y se separan, cambian y se transforman sin un plan, sin un objetivo unitario. Cada parte es un país soberano que simplemente convive en las contigüidades de un continente.

Teniendo en cuenta esa condición y tomando como referencia los procesos analizados por Frank Duffy en sus teorías de Design for Change $e^{108}$, Brand 
A

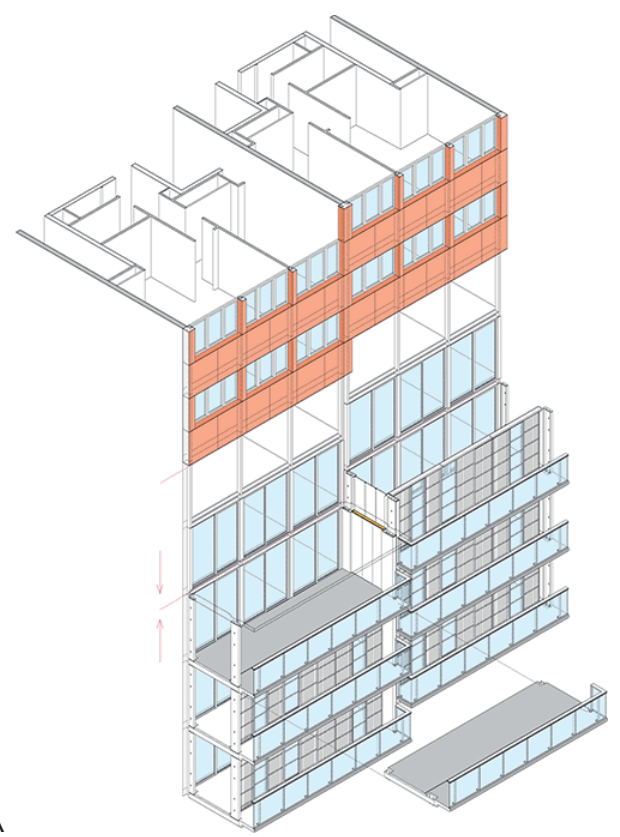

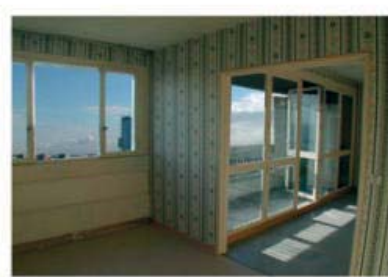

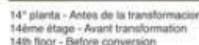

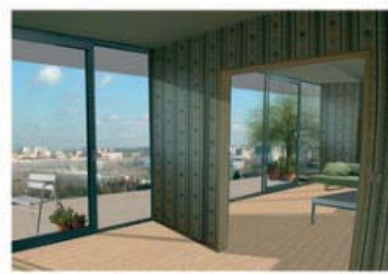

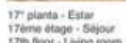

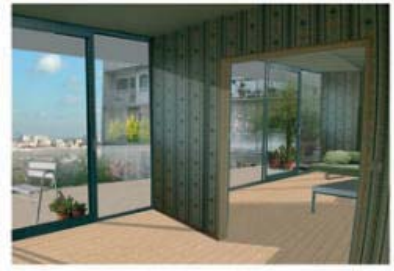

B

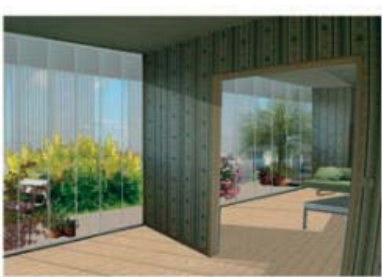

and

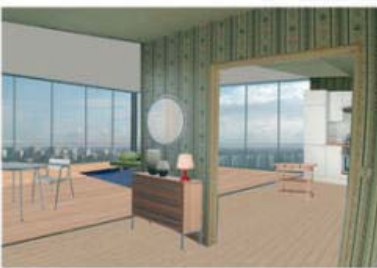

Fons

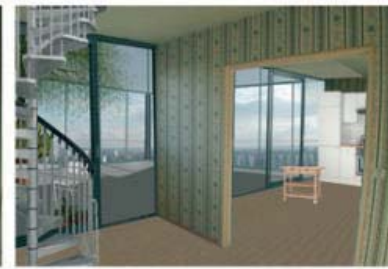

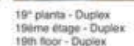

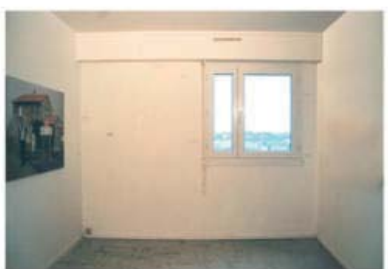

$=0$

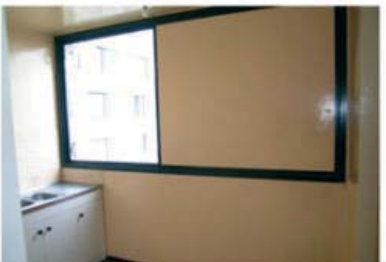

서에

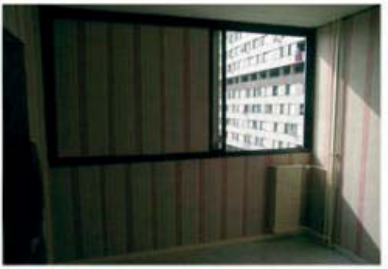

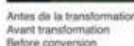

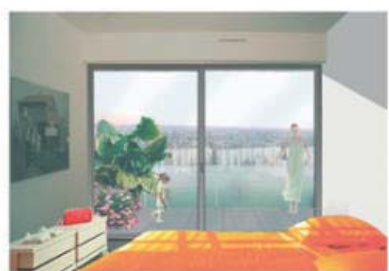

Nons

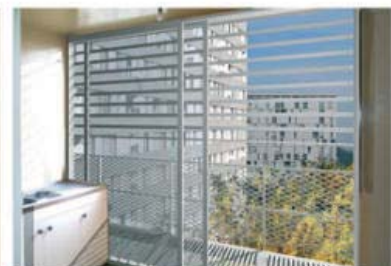

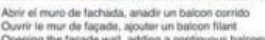

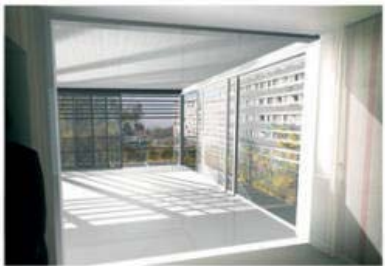

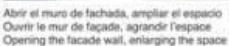


A. Druot Architecture y Lacaton \& Vassal. Bois Le Prêtre (2012).Axonometría.

B-C. Druot Architecture y Lacaton \& Vassal. Montajes explicativos de la transformación del edificio residencial Bois Le Prêtre, París (2013). establece un diagrama que muestra las condiciones del cambio a través del concepto gráfico de las Shearing Layers of Change. Su conclusión es que cualquier edificio puede leerse como una estratificación de diferentes niveles de cambio según un modelo gráfico sencillo. En el diagrama, cuya pretensión es de ser genérico, se muestra como un edifico puede ser descompuesto en diferentes capas, cada una de ellas independiente de las otras, y con propiedades específicas. El conjunto estaría formado por seis capas o estratos. Estas estarían organizadas en función de su resistencia a la alteración y, en el diagrama, quedan jerarquizadas a través del grosor de la línea. A mayor grosor más resistencia al cambio. Las seis capas son Site, Structure, Skin, Services, Space Plan y Stuff.

Site: Es el lugar en el que se asienta la construcción. Corresponde a la ubicación geográfica, la localización urbana o la parcela legal. Sus fronteras permanecen generaciones más allá de los edificios. Sus tiempos son extensos.

Structure: Es la estructura portante, todo aquello que sustenta lo construido. Su alteración requiere unos medios muy cualificados y su transformación es costosa por lo que, en general, casi nunca tiene lugar. Brand establece que la vida de las estructura va de los 30 a los 300 años, y es habitual que sobreviva a varias generaciones.

Skin: Es el límite que define la relación con el exterior. Engloba los cerramientos y las cubiertas. Brand fija sus ciclos de actualización en unos 20 años. En los últimos año, los costes de la energía han focalizado el interés en esta parte del edificio cambiando significativamente sus tiempos de renovación.

Services: Son las instalaciones o como los llama Brand, los intestinos. Su ritmo cambio oscila de media entre los 7 y 15 años. Es una capa activa y tiene mucha repercusión ya que, como recuerda el autor, si esta capa no es capaz de renovarse con facilidad el edificio está abocado a la desaparición. 

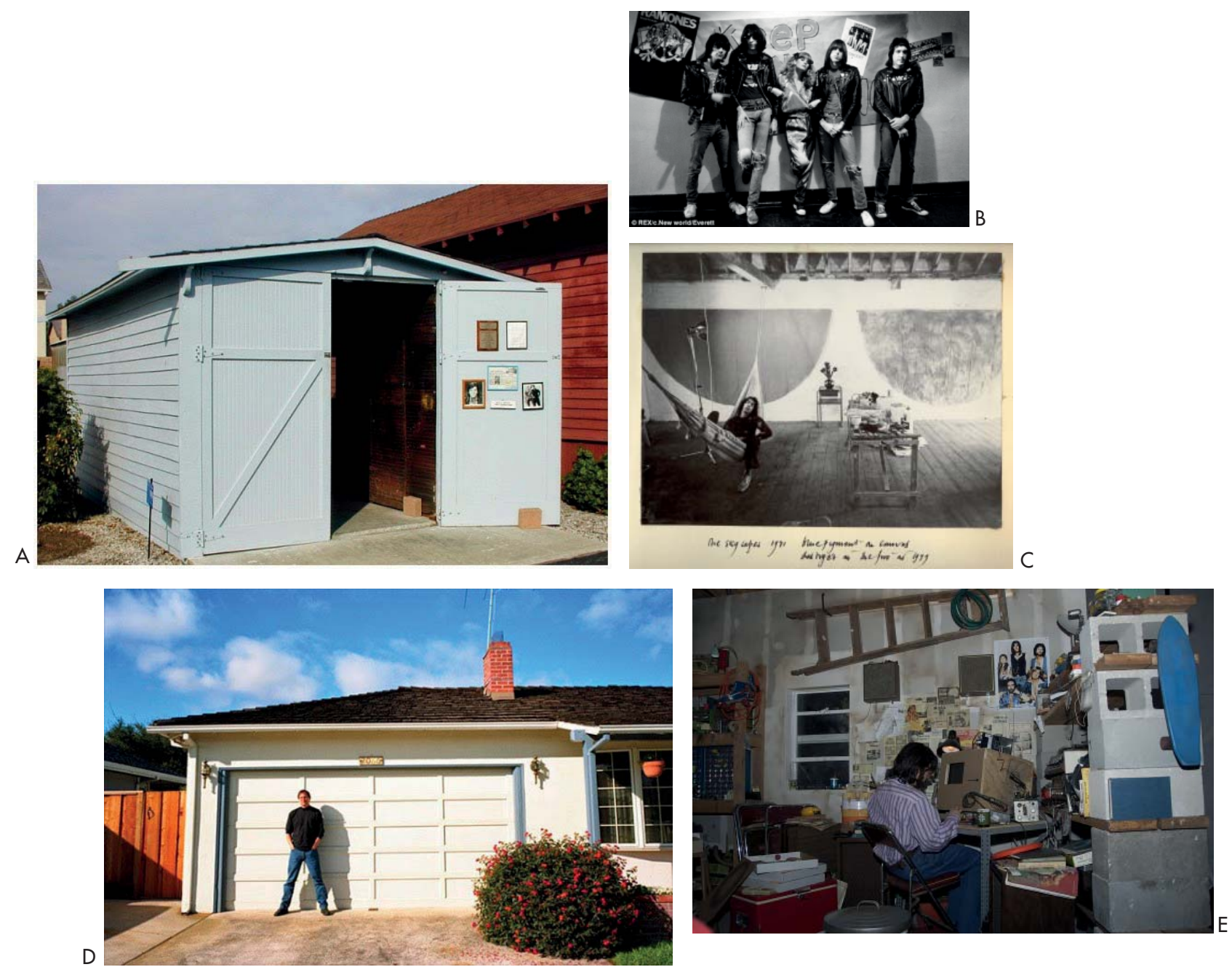
A. Estudio de Walt Disney.

B. Los Ramones.

C. Derek Jarman en su loft, 1971

D-E. Estudio de Apple. Garaje en casa de suburbio.
109. Esta teoría afirma que los ecosistemas pueden ser comprendidos mejor si se observan y analizan en función de los ritmos de cambio de cada uno de sus componentes. Estudiando la diferencia entre la rapidez de las flores y la lentitud de los árboles.
Space Plan: Es la distribución de tabiques y particiones. Su temporalidad varía sensiblemente, desde la alta frecuencia con la que se modifican los espacios comerciales, que llega a ser cada 3 años, hasta la lenta de los espacios domésticos que puede llegar a los 30 años.

Stuff: Son los objetos que pueblan lo construido: las sillas, mesas, teléfonos, cuadros, electrodomésticos, toldos o cortinas. Todo aquello que puede ser reorganizado y desplazado casi a diario.

Este entramado de capas determina la forma en la que los edificios entran en relación con las personas y con el medio en el que se ubican. Cada una de las capas introduce una forma de relación específica dentro de un ecosistema complejo que incluye los habitantes, la comunidad o la ciudad. Brand utiliza la teoría enunciada por Robert V. O’Neill, en su obra Hierarchical Concept of Ecosystems ${ }^{109}$, para demostrar como los edificios condicionan y están condicionados por cómo reaccionan al cambio. La conclusión es que en cualquier construcción se genera una relación de temporalidades en las que la dinámica del sistema estaría dominada por los componentes lentos que marcarían el ritmo del proceso. Al mismo la excitación de los cambios rápidos contamina y contagia a los procesos lentos que gradualmente van integrando las tendencias marcadas por los primeros. Las partes rápidas proponen mientras que las lentas disponen.

El diagrama de las Shearing Layers of Change sirve a Brand para analizar los edificios y evaluar su capacidad de adaptación:

"An adaptive building has to allow slippage between the differentlypaced systems of Site, Structure, Skin, Services, Space plan, and Stuff. Otherwise the slow systems block the flow of the quick ones, and the quick ones tear up the slow ones with their constant change. Embedding the systems together may look efficient at first, but over time it is the opposite, and destructive as well."

Todo edificio que mantenga la independencia de las capas y permita la evolución de las mismas sin condicionar a las restantes se convierte, bajo esa perspectiva, en un edificio prometedor para la adaptación. No tiene sentido, por lo tanto, juzgarlos por sus valores compositivos, estéticos o formales sino por su admirable genética para asumir el cambio, por su capacidad 


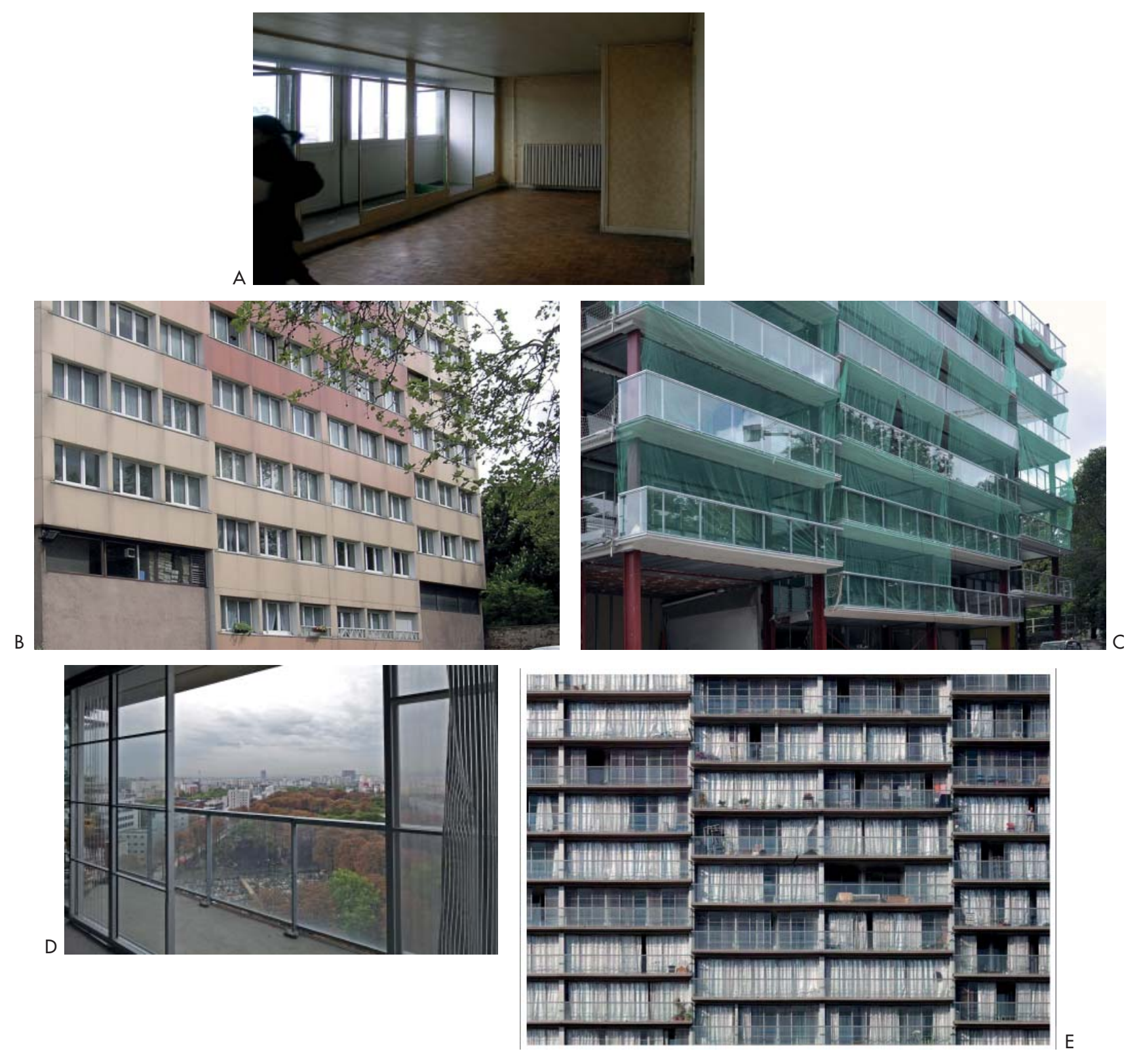


A. Bois Le Prêtre. Fotografía del interior previa a la reforma de 2012.

B. Bois Le Prêtre antes de la reforma de 2012

C. Druot Architecture y Lacaton \& Vassal. Bois Le Prêtre (2012). Fotografía de la fachada durante la obra de reforma.

D. Druot Architecture y Lacaton \& Vassal. Bois Le Prêtre (2012). Fotografía del interior.

E. Druot Architecture y Lacaton \& Vassal. Bois Le Prêtre (2012). Fotografía del la fachada. para sobrevivir a través de la mutación. Ejemplos paradigmáticos de estos espacios en la cultura americana serían el garaje en las casas de suburbio y el loft en el espacio urbano. Son territorios de excepción no normativizados, espacios en los que la indeterminación o la ausencia de imaginarios innatos ha permitido que puedan asumir como propios muchos otros. El garaje es hoy un espacio mítico e iniciático tanto para la cultura adolescente como para el mundo empresarial. Disney, Apple o Los Ramones comenzaron allí las trayectorias meteóricas que hoy conocemos. O qué decir de como el loft ha transformado los universos de lo doméstico, lo comercial y de la cultura.

\subsubsection{El caso Bois-le-Prêtre}

Al visitar el proyecto de Bois-le-Prêtre bajo la perspectiva del diagrama de Brand podemos hacer una interpretación de las limitaciones y dificultades para la adaptación del edificio original a lo largo del tiempo. El modelo de las Shearing Layers of Change visualiza el comportamiento del edificio por capas y demuestra el grado de autonomía de cada una de ellas. Al analizar la torre según el criterio de los estratos comprobamos que tanto el lugar como la estructura han permanecido inalterados durante los más de cincuenta años de vida del edificio. Por el contrario, la piel y las instalaciones han sufrido modificaciones sustanciales. La primera vez en 1990 con motivo de las obras que, como parte de la campaña para cumplir la normativa energética, buscaban la mejora del aislamiento térmico, reparación de fachadas y reforma de los sistemas de calefacción. La segunda coincide con la intervención de Druot, Lacaton \& Vassal e incluye otra vez el cambio de la fachada, la mejora de las instalaciones y las comunicaciones. Ambas alteraciones se han producido en ciclos inferiores a 30 años, adelantándose a las previsiones de Brand. Por lo que respecta a las capas de distribución interiores sabemos que han cambiado al menos en la última intervención, aunque es probable que cada inquilino haya realizado dentro de su piso modificaciones con cierta libertad.

Una primera lectura sería que las capas del edifico cuanto más desacopladas del resto más facilitan la mutación. Los propios arquitectos lo destacan así en la memoria que acompaña al proyecto de la torre: "Su sistema constructivo, 


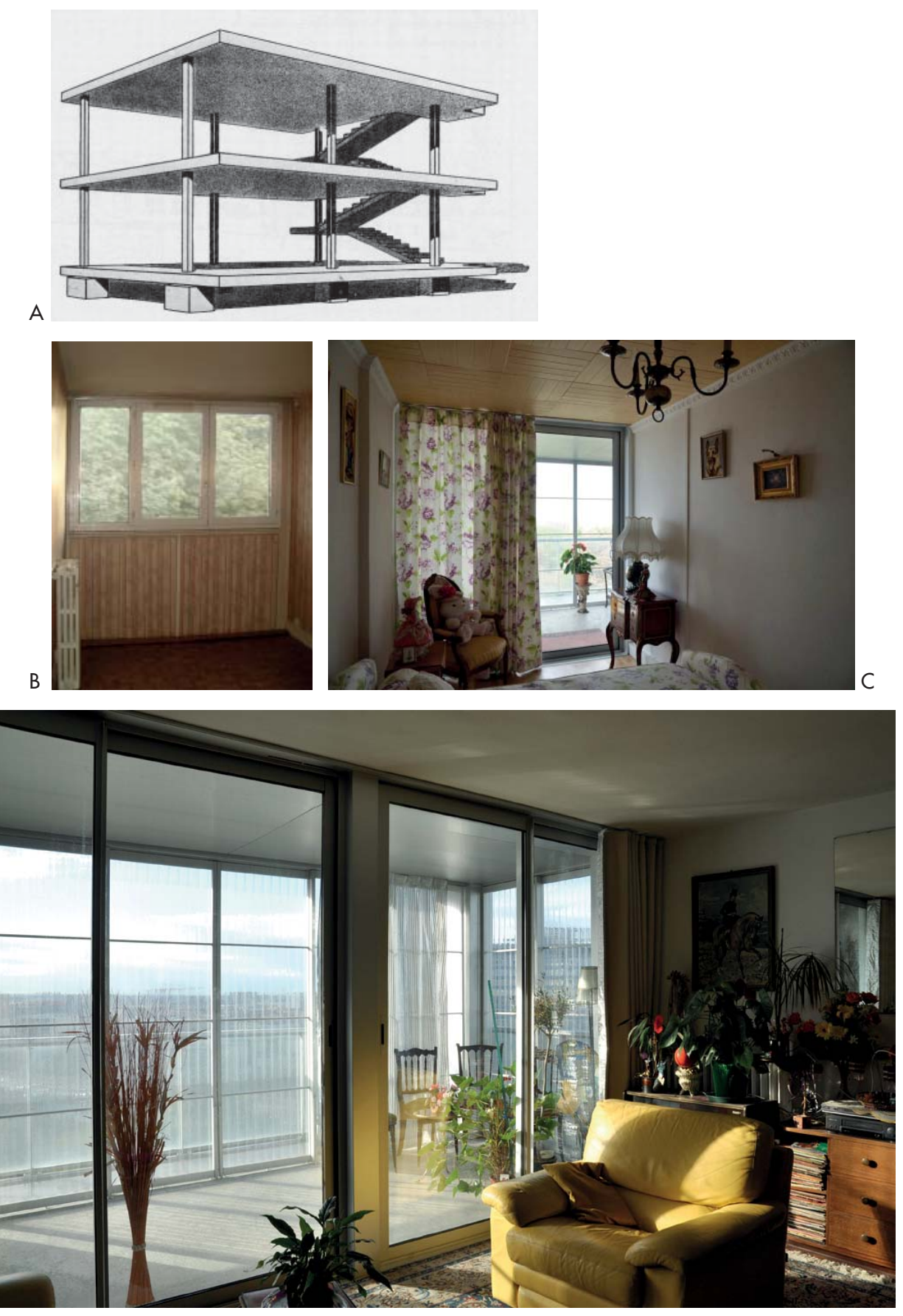


A. Le Corbusier. Maison Dom-Ino (1914).

B. Bois Le Prêtre. Fotografía del interior previa a la reforma de 2012

C-D. Druot Architecture y Lacaton \& Vassal. Bois Le Prêtre (2012). Fotografía del interior. independiente de la fachada, ofrece un potencial de transformación muy bueno". Bois-le Prêtre es indudablemente un heredero del movimiento moderno y de los principios de la planta libre. Lo que Le Corbusier había planteado en 1914 en la Casa Dom-ino como un sistema de libertad para la distribución, aquí se puede vislumbrar a través de la óptica de la degradación. La separación de las capas permite pensar en una construcción que sincroniza la cadencia de los tiempos de transformación con la durabilidad y resistencia de la materia. Todo pasa por la ventaja que otorga la desconexión de las capas. Por ejemplo, como hemos visto, la lógica constructiva de logias en la fachada del edificio original de los sesenta ha permitido que esta cambie hasta dos veces en 50 años. Sin embargo, los muros de hormigón perpendiculares a fachada que tienen la doble función de estructura y cerramiento condicionan la reorganización entre apartamentos y determinan el alcance de posibles cambios interiores. Estos últimos requerirían una energía mucho mayor para conseguir su alteración.

El ejercicio que realizan Druot, Lacaton \& Vassal al desplazar el ideal de las Case Study Houses nos muestra una doble lectura. Por un lado vemos como los arquitectos, al implementar el nuevo imaginario, están obligados a hacerlo siguiendo el criterio de los estratos diferenciados. Son conscientes de que no pueden negociar con el edificio como unidad. El imaginario penetra de forma desigual y encuentra acomodo de formas muy distintas. Por otro, las resistencias que encuentran determinan y construyen un imaginario nuevo, imperfecto si lo comparamos con el californiano pero innovador si lo describimos desde los mecanismos de la Economía Cultural.

Volvamos al fotomontaje de partida, aquel que mostraba la transición de la esquina del edificio. Una secuencia que arranca con la vista de una pequeña ventana en el muro y termina con una fachada de balcones corridos y ventanales de vidrio. El escenario para que el dandy observe la ciudad. En la imagen no solo la fachada ha desaparecido, también la estructura. Los planos horizontales levitan sobre la ciudad y trazan una estampa seductora. Esa imagen por si misma organiza una mitología del proyecto. Remite a la ligereza, estandarización, transparencia y economía de una modernidad redefinida. Al proyectar, literal y metafóricamente, la mitología sobre el edificio existente aparecen fricciones y desajustes con los que los arquitectos deben mediar. 

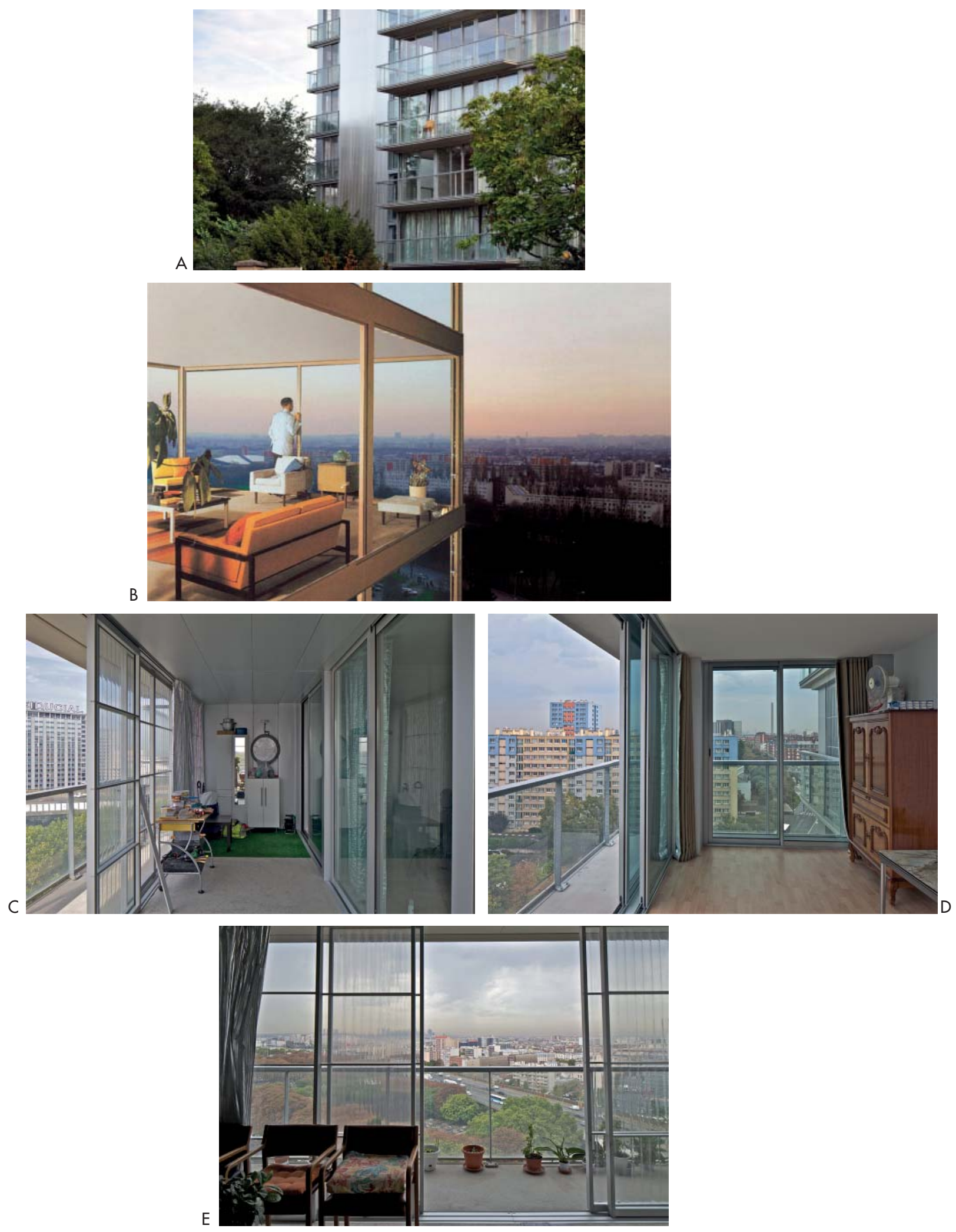
A. Druot Architecture y Lacaton \& Vassal. Bois Le Prêtre (2012). Fotografía del exterior.

B. Druot Architecture y Lacaton \& Vassal. Montaje para la reforma del edificio residencial Bois Le Prêtre, París (2013).

C-E. Druot Architecture y Lacaton \& Vassal. Bois Le Prêtre (2012). Fotografías del interior.
En este edificio el caso de la esquina es paradigmático. Si seguimos las intenciones del fotomontaje, para que el imaginario se realice en su totalidad, es necesario deshacer la esquina, lograr que el juego de transparencias del encuentro entre los planos consiga la ligereza de la Casa Koenig. Sin embargo, la torre fue diseñada con una estructura vertical de muros de hormigón perpendiculares a la fachada. Estos muros se muestran en los testeros del edificio como grandes superficies opacas, justo lo contrario al efecto deseado. En esta ocasión estructura y cerramiento quedan solapados en una misma capa. Su resistencia es máxima, su transformación limitada. La aplicación del imaginario inicia su contorsionismo para encontrar su acomodo. Los arquitectos proponen una doble solución. Hacia el oeste desisten y dejan visto el muro exterior opaco, lo opuesto a la transparencia prometida. Es raro encontrar una fotografía entre los reportajes de la obra en la que quede registro de esa solución, acostumbrados a la visión de los balcones corridos a lo largo del edificio sorprende esta cara que se aleja tanto de la mitología del edificio. Por el contrario en la orientación este el testero de hormigón queda oculto al añadir una extensión en forma de habitación por la cara exterior. La habitación se construye libre de las restricciones del edificio original. En el interior sin embargo queda el muro como memoria de la resistencia. La imagen de ese alzado es a la que recurren para mostrar el resultado final. La esquina, aunque contiene el espíritu del fotomontaje, se enfrenta a otros retos que la distancian de su idealización. Una torre no es una casa, la estructura en la esquina deja de ser una fina arista para manifestarse con fuerza estructural. El pilar se retranquea ligeramente y queda velado por los vidrios desde el exterior, en cambio por el interior adquiere una presencia notable. De la ligereza de las Case Study Houses apena queda nada.

Otro cambio notable se manifiesta en los componentes de la fachada. París no es Los Ángeles, los cambios de temperatura son amplios y el clima semicontinental obliga a soluciones más contundentes que las hojas simples de las casas californianas. También la normativa y el compromiso de los arquitectos por el ahorro energético exigen soluciones más complejas para cumplir con los estándares requeridos. Druot, Lacaton \& Vassal optan por utilizar un sistema que ya han probado con éxito en otros proyectos. Crean una cámara de policarbonato entre la terraza y el antiguo exterior para mitigar los saltos térmicos entre el interior y el exterior. Con esta decisión la transparencia se pierde, la mirada se enturbia cuando traspasa la ondulación 

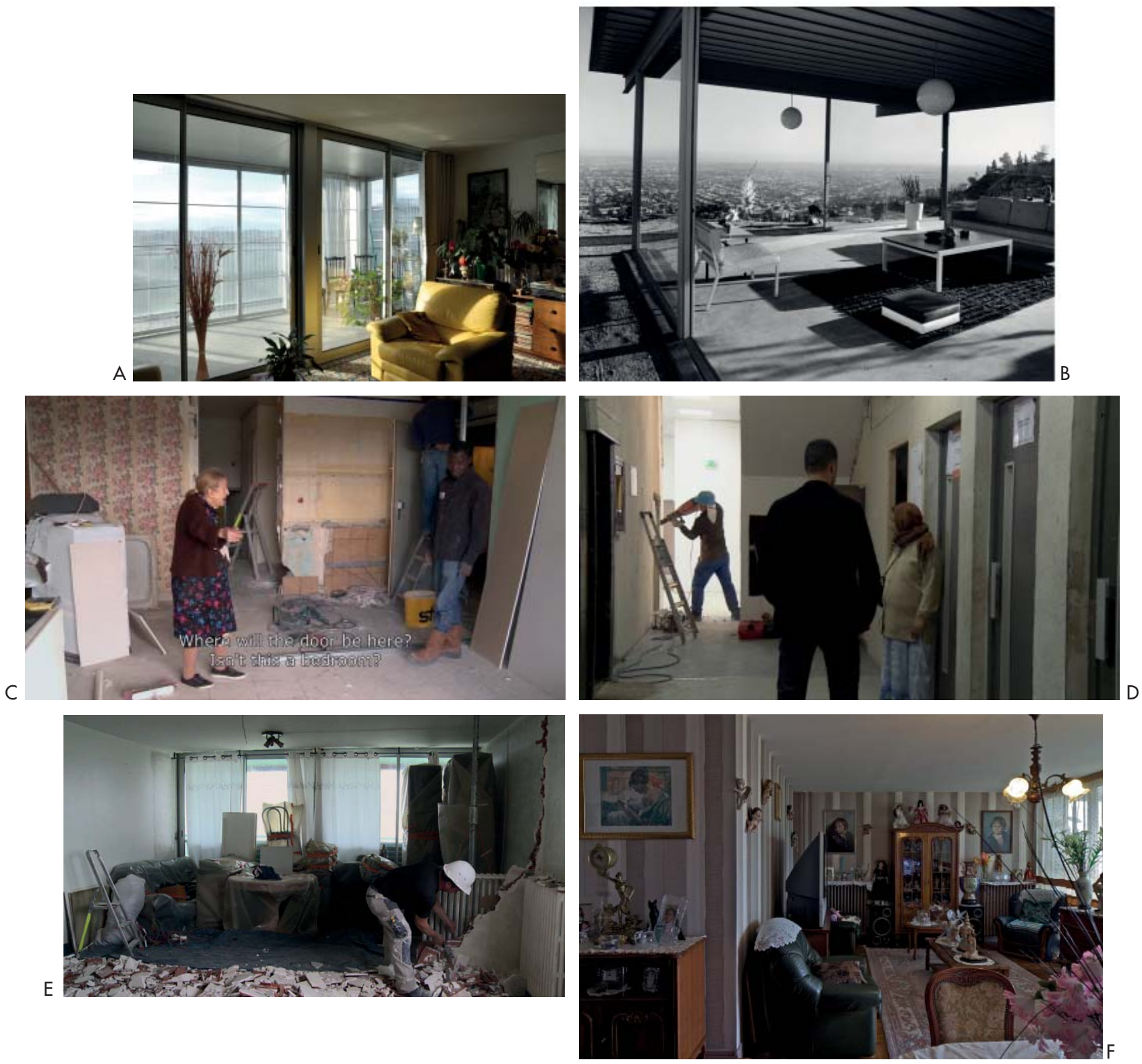
A. Druot Architecture y Lacaton \& Vassal. Bois Le Prêtre (2012). Fotografía del interior.

B. Pierre Koenig. Stahl House. Case Study House n. 22 (1960).

C-E. Druot Architecture y Lacaton \& Vassal. Bois Le Prêtre, París (2012). Fotografías del proceso de reforma del edificio.

F. Druot Architecture y Lacaton \& Vassal. Bois Le Prêtre (2012). Fotografía del interior.

110. El antes y el después del proyecto se puede consultar en el documental HLM, Habitations Légèrement Modifiées (2013) o en la publicación dedicada a la torre Tour Bois Le Prêtre, Druot, Lacaton y Vassal, 2012

$111 . \quad$ Leila Terrand, propietaria de uno de los apartamentos lo confirmaba: "We could select the colors of the flooring and curtains ourselves and I could choose between five different versions of the floor plans". Druot, Lacaton \& Vassal, 2012: 35 del material pero el habitante gana un regulador climático, un mediador con la naturaleza. El proyecto resultante produce y define una nueva belleza, un nuevo imaginario termodinámico.

Hasta ahora hemos visto como la resistencia a la transformación se debía fundamentalmente a la reticencia de la materia para ser alterada según su condición o posición en el diagrama de las Shearing Layers of Change. La estructura ofrece su máxima resistencia y condiciona las operaciones de los arquitectos. Todo encaja con las predicciones de Brand, por lo menos para los estratos de cambio lento. Sin embargo si miramos a las de cambio rápido podemos apreciar que se produce un desajuste. La mayoría de los interiores han permanecido prácticamente idénticos a lo que era su condición previa. ${ }^{110}$ Sabemos por las conversaciones de los propietarios que en diversas ocasiones los arquitectos asesoraron y dieron libertad para la elección de materiales y acabados. ${ }^{111}$ Es presumible que los arquitectos, para explicar el proyecto a los propietarios, mostraran los fotomontajes para que se pudieran hacer una idea del resultado final. A pesar de esto, los interiores no parecen haberlos tomado en cuenta para su transformación. Están bien lejos de ser la habitación del dandi californiano. No son solo los muebles, también cortinas, papeles de pared y embaldosados han sido resistentes al nuevo imaginario. Es evidente que los arquitectos no fueron beligerantes al respecto, sino por el contrario, animaron a que cada uno de los propietarios se hiciera cómplice de la apropiación del nuevo espacio. No nos interesa tanto destacar la distancia que toma el arquitecto con respecto de su obra sino otra dimensión de la resistencia de la materia. Lo que se hace visible a través de este ejemplo es que las capas del diagrama que supuestamente cambian con mayor celeridad, es decir, los acabados interiores y el mobiliario se enfrentan a otro tipo de resistencias que tienen su origen en los vínculos sentimentales que se crean entre los habitantes y sus objetos. Los afectos constituyen también, desde otro punto de vista, un freno que limita la incorporación de los imaginarios. 

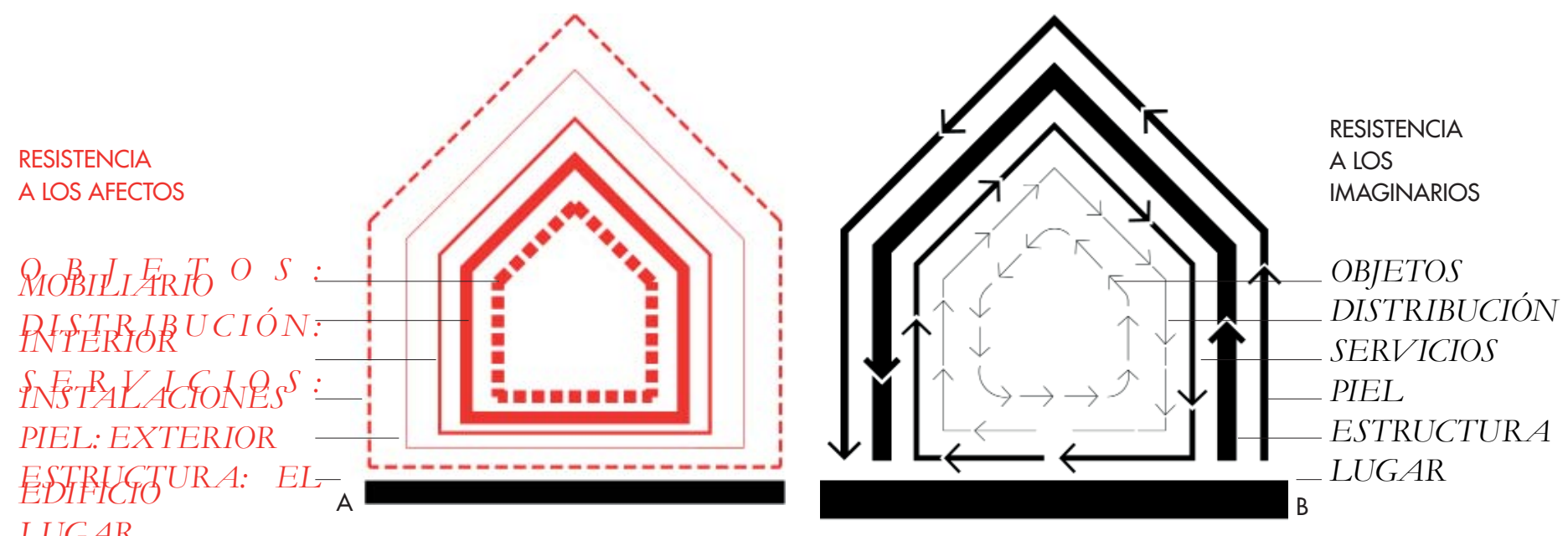
LUGAR 


\subsection{TEORÍA DE LA RESISTENCIA A LOS IMAGINARIOS}

A. Diagrama de Resistencia a los Afectos. B. Stewart Brand. Diagrama Shearing layers of change (1994)
Los modos de preservación que se ponen en juego en la obra de Druot, Lacaton \& Vassal no están motivados, como hemos visto, por la angustia de la desaparición de aquello que nos representa como cultura sino por el compromiso de activar el potencial que, en forma de energías cautivas, guarda cualquier arquitectura. Que lo edificado viaje al futuro no pasa exclusivamente por la significación u otros modelos de momificación sino que existe una manera alternativa basada en el cambio y la transmutación de valor a través del desplazamiento de imaginarios. Sin embargo, los objetos ni son inertes ni obedecen ciegamente, tienen la capacidad de bloquear la acción del diseño, desviando la trayectoria de estos. Es uno de sus poderes, viven a pesar de nosotros, en ello reside parte de su belleza. Las acciones de los habitantes no determinan las trayectorias pero dan impulso a la materia. La acción del diseño y la resistencia de lo físico se equiparan y nos obliga a abandonar la idea de subordinación de las cosas a lo dictado por los humanos.

La hipótesis de partida de esta investigación se fijaba en las herramientas del proyecto capaces de revertir la obsolescencia de lo existente. Después de visitar el trabajo en los conjuntos habitacionales franceses de Druot, Lacaton \& Vassal estamos en posición de afirmar que las formas de revertir la obsolescencia solo pueden tener éxito desde la operación sobre los imaginarios. Para entender la dimensión de esta afirmación es necesario no confundir la obsolescencia con un indicador de la fatiga de la materia. La obsolescencia es una caída en desuso ${ }^{112}$ que no se debe a un mal funcionamiento sino a un insuficiente desempeño de las funciones en comparación con otros objetos, en este caso, con otras arquitecturas similares. La obsolescencia es una proyección de lo humano sobre los objetos, es el espejo de nuestra falta de entusiasmo. Por eso no es extraño que la obsolescencia se trate desde una perspectiva económica pues está basada en una jerarquía de valores y, como hemos visto, esta jerarquía esta netamente construida desde lo social. Lo que nos muestra la operación sobre la torre de Bois-le Prêtre es que cualquier acción sobre la arquitectura existente que no incorpore una representación social seductora y renovada será incapaz de movilizar la empatía de habitantes o ciudadanos. Las acciones con soluciones exclusivamente cuantitativas, como la ocurrida en la renovación de los años ochenta sobre la torre, difícilmente pueden 


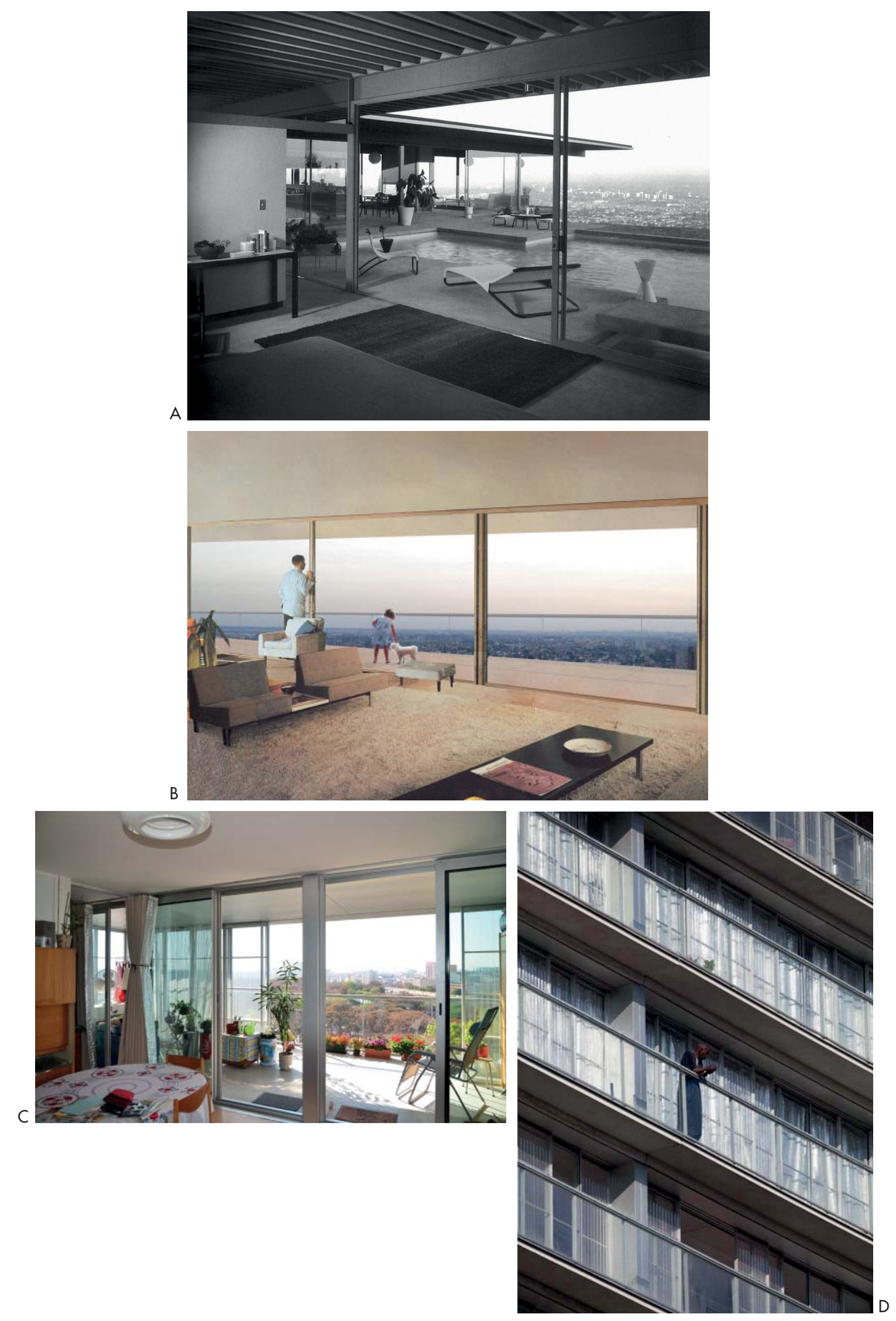


A. Pierre Koenig. Stahl House. Case Study House n. 22 (1960).

B. Druot Architecture y Lacaton \& Vassal. Montaje para la reforma del edificio residencial Bois Le Prêtre, París (2013).

C. Druot Architecture y Lacaton \& Vassal. Bois Le Prêtre (2012). Fotografía del interior.

D. Druot Architecture y Lacaton \& Vassal. Bois Le Prêtre (2012). Fachada del edificio. alargar la vida si existe una percepción negativa y distante en la sociedad que la habita. La materia no se agota, se agota nuestra experiencia. De ahí que para cerrar este capítulo sea necesario establecer como conclusión los vínculos o relaciones que se establecen entre materia e imaginarios.

Proyectar sobre lo existente mediante el desplazamiento de imaginarios es una estrategia tan antigua como recurrente. ¿No es exactamente eso lo que ocurrió en la Mezquita de Córdoba cuando se transformó en Catedral? ¿O lo que hizo que la Factory no fuera un almacén más? Aquí la hemos estudiado en profundidad a través de la obra de Druot, Lacaton \& Vassal lo que nos ha permitido entender que no es una acción pacífica ni ajena a tensiones. Podríamos resumirlo en que el desplazamiento de imaginarios se enfrenta a dos tipos de resistencias. La primera tendría que ver con la inercia de la materia, con la dificultad de poner en marcha su transformación, tanto por su tenacidad, los costes energéticos o económicos asociados. Este tipo de resistencia estaría ilustrada en el diagrama de Stewart Brand y mostraría como lo construido, según su función y consistencia, se moviliza en ciclos temporales específicos. Se constituye desde el origen del proyecto, desde su diseño e instaura un marco limitado de posibilidades. Los estados intermedios de transformación, como hemos visto, marcarán su tendencia y dejarían su propia huella sobre los relatos con ella asociados.

Por el contrario habría otro tipo de resistencia que tiene que ver con lo simbólico y con los afectos que los habitantes establecen con los objetos. En nuestra visita hemos identificado que estos afectos se impregnan en aquellas capas que cambian con más asiduidad. Cuanto más accionable y rápida es la transformación más presencia tiene la red de vínculos emocionales con los objetos. Pero que actúen sobre las capas rápidas no quiere decir que los afectos se construyan a esa velocidad, por el contrario, son una decantación lenta construida por fantasías y deseos puestos a prueba. Los habitantes de la Torre habrían hecho suyo el espacio a través de lo que podríamos llamar una relación amorosa con los objetos. El resultado es que muebles, papeles de pared, entelados o revestimientos cerámicos se consolidaban mientras otras capas supuestamente más lentas cambiaban. Estos apegos no son transferibles. Solo entran en juego mientras los usuarios viven el espacio. Con la llegada de los nuevos inquilinos son erradicados. En definitiva, la resistencia de los afectos se vuelve en cierto modo complementaria con 

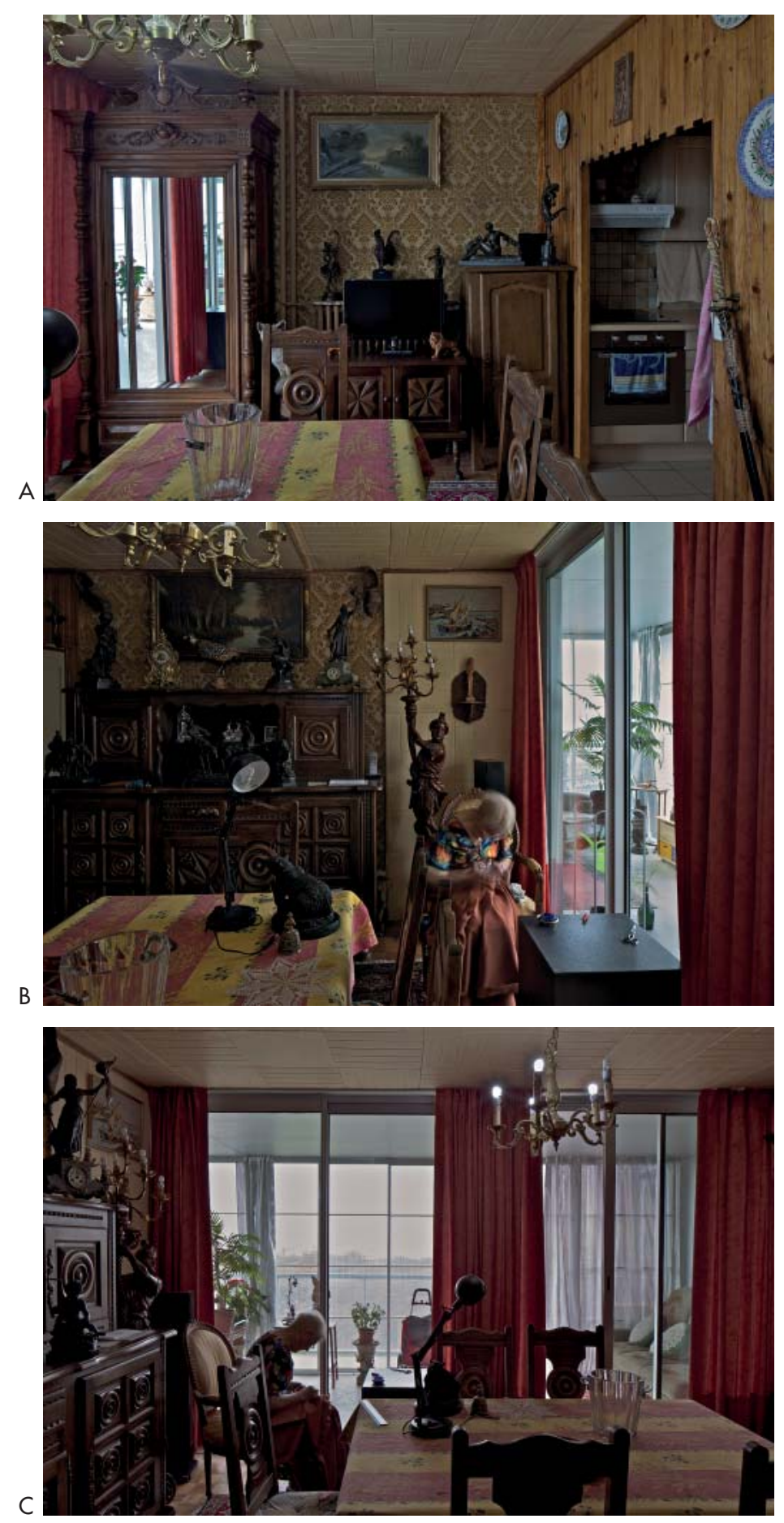
A-C. Druot, Lacaton \& Vassal. Bois Le Prêtre (2012). Fotografías del interior.v respecto a la resistencia material y juntas conforman una forma compleja de oposición al cambio.

Por último quizá estemos en posición de proponer una hipótesis aplicable a la transformación de cualquier edificio ordinario. La hemos denominado Teoría de la resistencia a los imaginarios y en ella se enuncia que existe una vinculación entre la resistencia al cambio de los diferentes estratos en un edificio y la capacidad de estos para asumir imaginarios y conservarse en función de los afectos.

Las implicaciones de esta Teoría son múltiples y las hemos ido enunciado a lo largo del capítulo de formas diversas. La resumimos:

-Las arquitecturas ordinarias pueden transformarse de forma eficaz a través del desplazamiento de imaginarios. Este proceso consiste en aplicar un imaginario ajeno y seductor a lo edificado ordinario. Dichos imaginarios trasladados de forma arquitectónica construirán un nuevo marco de interpretación de la pieza existente y por lo tanto promoveran nuevos entusiasmos.

-Los imaginarios encuentran en la materia su principal bloqueo. La implementación del nuevo imaginario requiere de una puesta en obra específica que no siempre coincide con la disposición de lo existente. La tenacidad de lo construido al cambio se manifiesta en forma de resistencia.

-Los afectos de los habitantes también condicionan el desplazamiento de los imaginarios. La inclinación por determinados objetos o materia edificada se exterioriza en forma de resistencia cuando son objeto de alteraciones.

-Si tomamos como referencia la descripción de las Sharing Layers of Change de Brand, en los estratos de transformación lenta el desplazamiento de los imaginarios tropieza fundamentalmente con la resistencia de la materia, con la parte física. En cambio, en los estratos de transformación rápida, la resistencia está condicionada basicamente por los afectos de los habitantes.

-La resistencia material es constante, su tenacidad es prolongada. La resistencia de los afectos es intermitente y cambiante. La primera es estructural, la segunda coyuntural. 


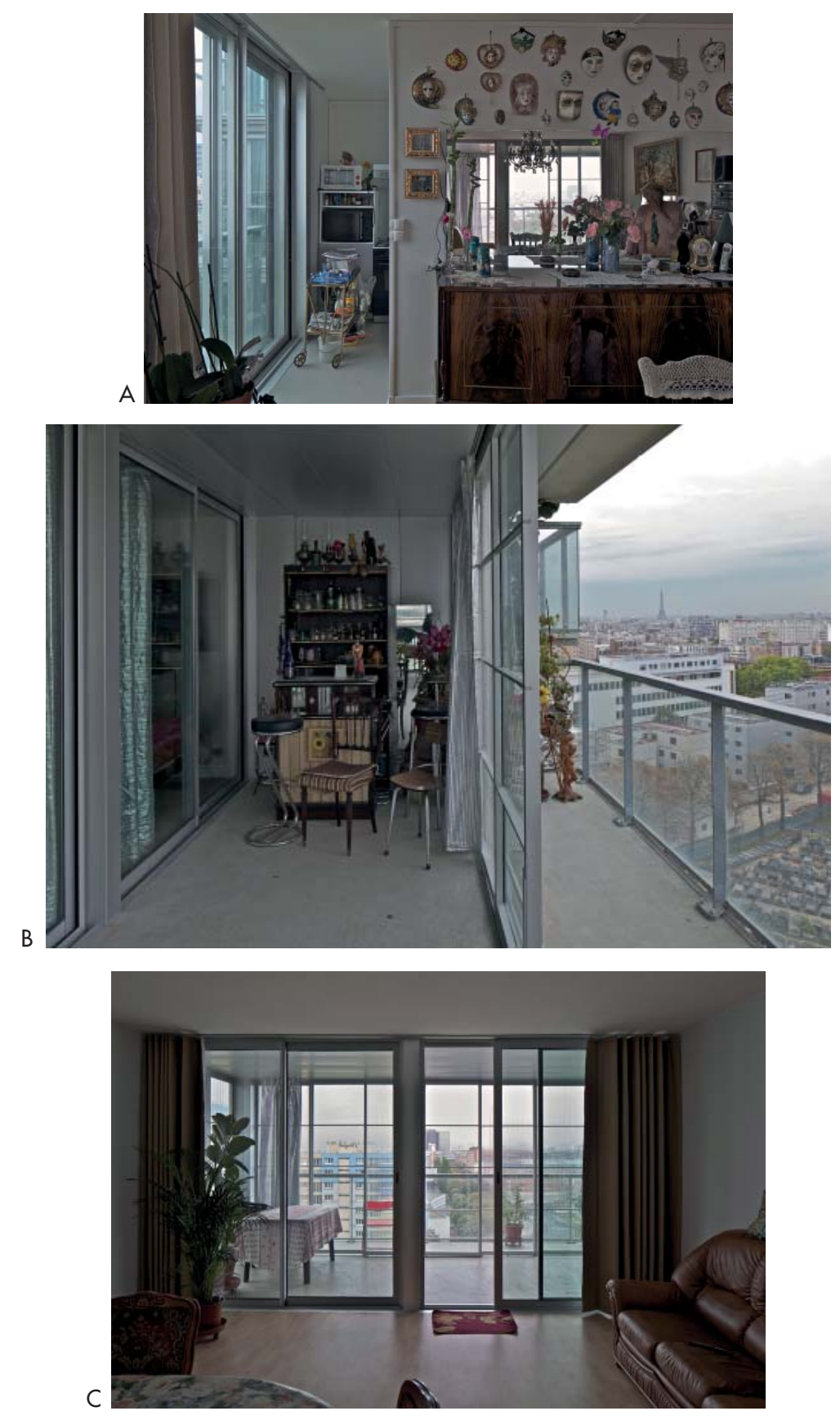


A-C. Druot Architecture y Lacaton \& Vassal. Bois Le Prêtre (2012). Fotografías del interior.

113. La conclusión particular a la que hemos llegado en este punto tendría una enunciación teórica más general en las teorías de la ecología política de las cosas
-La materia y los objetos que constituyen lo edificado, no son inertes ni obedientes, sino que establecen una forma de agencia que se renueva con la incorporación de los imaginarios. No es dócil con el diseño pero tampoco es inmutable. Lo existente se reajusta definiendo límites y abriendo nuevas posibilidades. ${ }^{113}$

-Los cambios de las capas lentas se producen de forma veloz y de una vez. Los cambios de las capas rápidas son por lo general intermitentes y lentos. El primero es una descarga puntual el segundo un goteo.

-Cualquier imaginario tiene más posibilidades de doblegar la obsolescencia si es capaz de asumir los compromisos de su época y definir una nueva belleza. La resistencia de lo existente a los imaginarios lejos de ser un impedimento para alcanzar dichos objetivos resultará ser parte fundamental del proceso de innovación. 

PARTE II 



\section{CAPÍTULO 3.}

TRANSMUTACIÓN DE

VALOR Y SIGNIFICADO:

LA CASA DE GEHRY EN

SANTA MÓNICA 

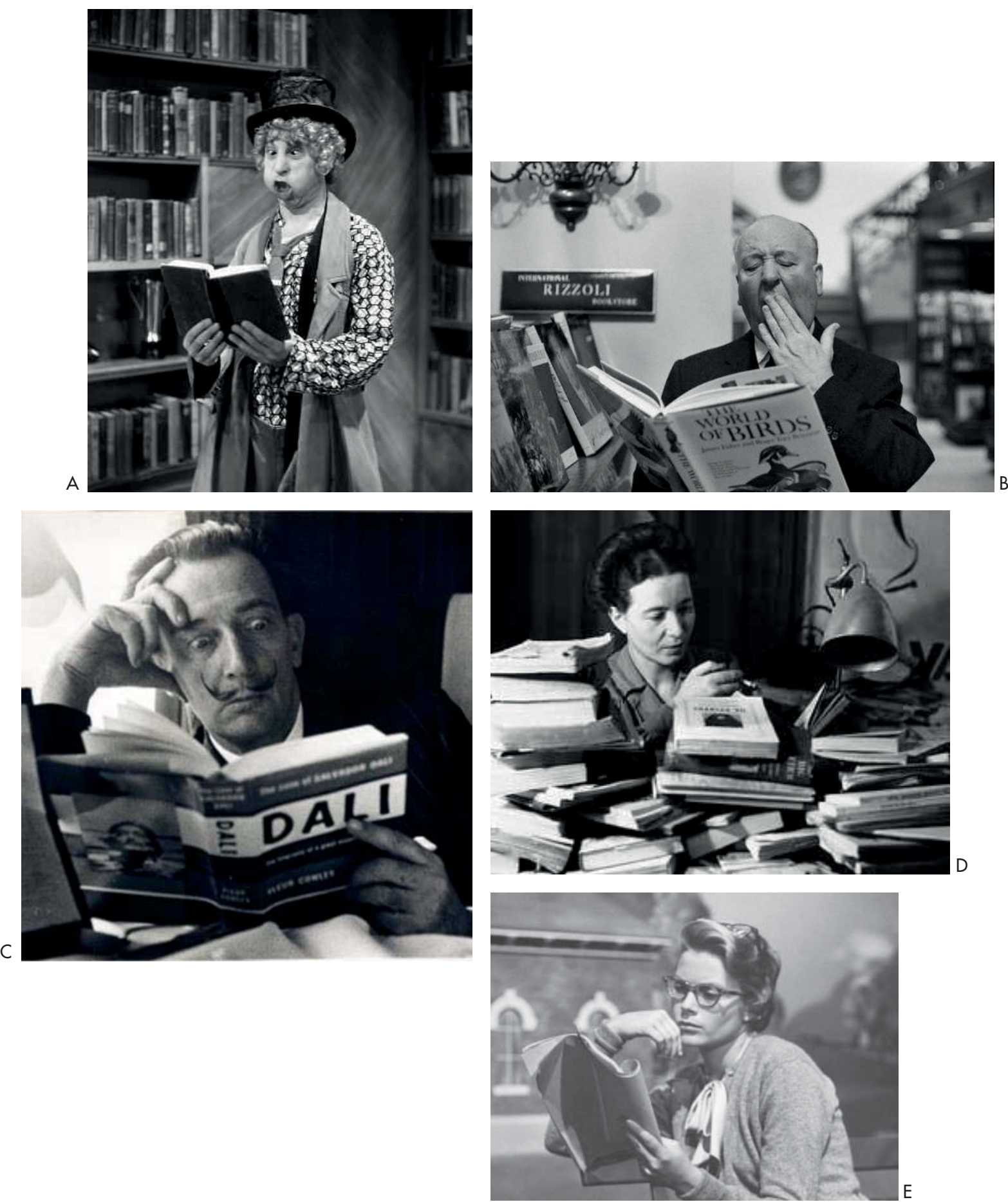
Aprender a babitar el mundo en lugar de querer construirlo.

Nicolas Bourriaud

It was just a dumb little house with charm.

Frank Gehry

\subsection{AMUEBLAR EL MUNDO 114}

\footnotetext{
A. Harpo Marx (1888-1964).

B. Alfred Hitchcock (1899-1980).

C. Salvador Dalí (1904-1989.

D. Simone de Beauvoir (1908-1986)

E. Grace Kelly (1929-1982)
}

114. Esta sección es una reelaboración del texto Amueblar el Mundo escrito por María Langarita y Víctor Navarro y publicado en la revista Quaderns. Véase Langarita, 2011.
Tarde o temprano, nuestro cuerpo, cuando no le prestamos atención, cobra extraña vida. Lo extraño, claro, no es la vida sino como lo hace: en fracciones, como si una a una cada una de las partes hubiera decidido proclamar su independencia del resto. Somos capaces de mover nerviosamente una pierna para desanimar a una mosca a posarse mientras la mano contraria a la que soporta el libro que leemos decide remontar a contrapelo, desde la nuca, toda la cabeza. Si describimos cualquier acción distraída de nuestro organismo o traducimos los movimientos ligeros que, de cabeza a pies, trazan nuestras piernas negociando con los pantalones o nuestros brazos ajustándose en el interior de la camisa, podremos reconocer la dificultad de asumir esos desplazamientos como un acto único. Más bien, cabe describirlos como una superposición de acciones inconexas. No nos interesan aquí todos los movimientos. Descartemos los impostados y los autoconscientes: el del tenista que acomoda su figura para trasmitir energía cinética a una pelota o el que da la vuelta a una tortilla con un golpe seco de sartén. En ambos, las piernas ajustan su posición para dar estabilidad, el torso se estira y deja que los brazos se coloquen con libertad antes de dar el latigazo. Las partes del cuerpo actúan en consideración unas a otras, con tremenda responsabilidad. No existe espacio para el error, quizá exista una segunda oportunidad para el tenista, pero para el cocinero cualquier fallo solo augura un desenlace fatal. 

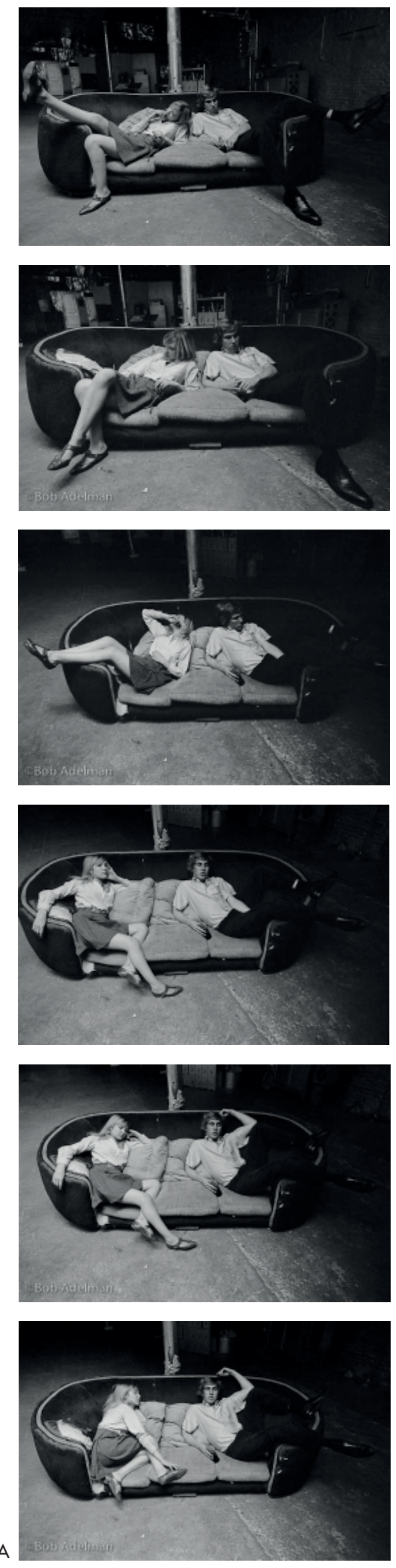
A. Joven actriz y Chuck Wein en el sofá rojo en The Factory. Nueva York, 1965. Autor Bob Adelman.
Queremos precisamente fijarnos en los movimientos que no se dan importancia, aquellos que surgen sin darnos cuenta. Estas agitaciones son la mediación entre el organismo y su entorno, no como un acto organizado sino como la respuesta a pequeñas y concretas batallas que se libran en sus límites. Como si aplicarámos esa curiosa expresión, estar fuera de sí, no solo a cuando perdemos los nervios, sino también a cuando los nervios han decidido tomar cada uno el camino por su cuenta. Estar fuera de sí es estar ocupando otro lugar dentro de uno, o traer a uno las formas de ser de otro. En ese movimiento colectivo y esquizofrénico de nuestro cuerpo distraído las diferentes partes se enfrascan en un cometido que las ubica en un sistema de referencias propio. El resultado, visto en conjunto, no se puede definir como una acción unitaria sino como un habitar coordinado y cómplice. El cuerpo se convierte en un lugar de encuentro. Y por eso avanzamos que, cuando observemos las arquitecturas que provienen de las agrupaciones heterogéneas en lo existente, nos recordaran a esta forma de ser desconectada. Reconoceremos en ellas mecanismos parecidos que hacen posible la coexistencia y la simultaneidad de lo diverso. Mantengamos esta escena en la memoria y volvamos a nuestro estudio.

Hemos iniciado esta investigación enunciando que las arquitecturas que trabajan para revertir la obsolescencia de lo existente con la lógica de las agrupaciones heterogéneas son un estado de encuentro, un dispositivo capaz de poner en común lugares remotos. A través del concepto de las agrupaciones heterogéneas hemos entendido las dimensiones que se abren al utilizar la herramienta proyectual del montaje, un instrumento que hace posible la simultaneidad y la coexistencia. Por otro lado, en nuestra visita a la intervención sobre arquitecturas existentes hemos comprendido, dejando a un lado las interpretaciones de la significación, como la materia se constituye como una amalgama estratificada de energías que lejos de ser pasiva o inerte tiene capacidad de agencia. Ahora estudiaremos el resultado de su intersección como proyecto arquitectónico y entenderemos que dimensiones, de las que hemos investigado, se abren cuando las arquitecturas habitan y operan en esa región.

Como hemos visto, toda arquitectura construida es un contendor de materia y conocimientos. Es un túnel del tiempo en estado de latencia. Pero, como cualquier túnel del tiempo, necesita un desencadenante 

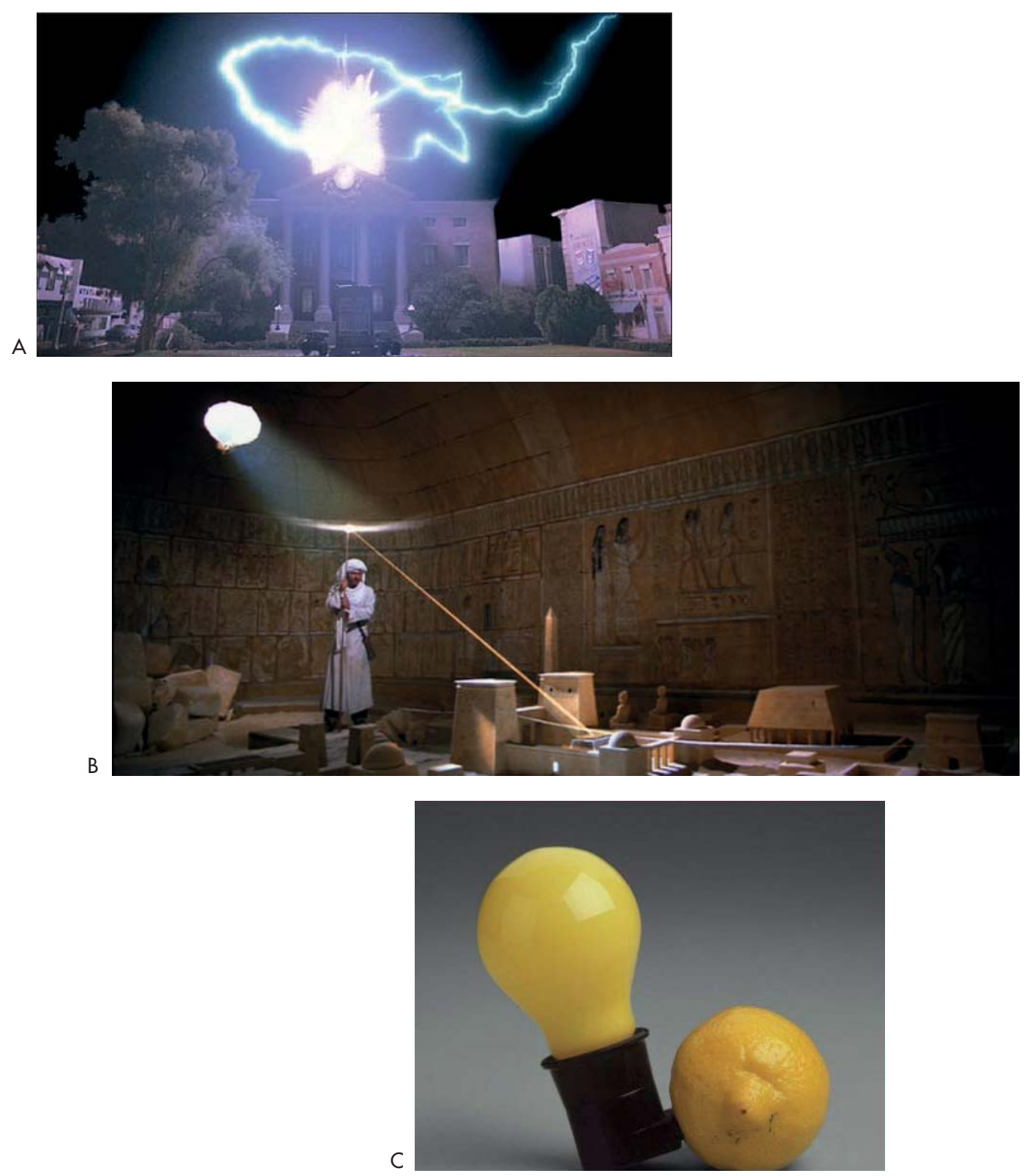
A. Fotograma de la película Back to the Future de Robert Zemeckis. Traducida al español como Regreso al futuro. (1985)

B. Fotograma de la película Indiana Jones and the Raiders of the Lost Ark de Steven Spielberg. Traducida al español como En busca del arca perdida (1981).

C. Josehp Beuys. Lemon light/Capri Battery (1985)
$115 . \quad$ Iñaki Ábalos, como ya hemos visto en el segundo capítulo, se refería al resultado de las agrupaciones heterogéneas dobles como a monstruos o un Frankenstein. Véase Ábalos, 2015. 116. Nos referimos al término en el sentido en el que lo utiliza Nicolas Bourriaud en su libro Esthetique Relationnelle (1998)

117. Bourriaud, 2006: 13 que inicie su actividad; algo o alguien que la convoque, la haga visible y también operativa. En el arte, la literatura o el cine para que esto ocurra es necesario un conjuro, una alineación de acontecimientos o un dispositivo tecnológico. Supone el arranque del flujo del tiempo, el inicio de una nueva forma de entender el presente y de habitar los futuros y los pasados. Esta investigación propone que ese acontecimiento en arquitectura ocurre, al menos, cuando intervenimos sobre una arquitectura existente ordinaria bajo los mecanismos de las agrupaciones heterogéneas. En ese momento de compatibilidad e incompatibilidad, de parecido y diferencia, de sistemas semejantes y alternos se pone en marcha todo un nuevo mecanismo de relaciones que permite hacer visibles y comparables los desplazamientos de la materia entre diferentes mundos: el de lo profano y los archivos de la cultura, el de los imaginarios existentes y los nuevos aportados o el de las tecnologías previas y las incorporadas. Se constituye así un modo de innovación, una transmutación de valor y de significado de la materia encontrada. Esta transformación no consiste en una desfiguración de lo existente, no implica, como haríamos con un metal, fundir la masa para dotarla de una nueva forma. Por el contrario, esta manera de operar mantiene el cuerpo arquitectónico reconocible y lo activa, como en el ready made, según nuevas coordenadas. Revertimos la obsolescencia en el momento en el que la arquitectura precedente es interpelada por la nueva. Cambia la forma en la que la percibimos. Lo que se despliega ante nuestros ojos es algo extraño, se ha dicho que monstruoso, ${ }^{115}$ pero también, como vimos en el desplazamiento de los imaginarios, lo percibimos como un constructo fascinante y seductor.

Este modo de operar abre una forma de entender la práctica de la arquitectura desde paradigmas relacionales ${ }^{116}$ que erradica el pensamiento de superación histórica. Frente a esa herencia moderna de un arquitecto mesiánico que carga sobre sus hombros la necesidad de deshacer el mundo para construirlo de nuevo, surge un nuevo modelo menos ambicioso y más oportunista, cuya filosofía se alinea con un modo de entender las prácticas creativas desde una perspectiva menos invasiva. Nicolas Bourriaud ha sintetizado con acierto la actitud como la voluntad de "aprender a habitar el mundo, en lugar de querer construirlo según una idea preconcebida"117

Ese "aprender a habitar el mundo", entraña como mínimo ser consciente de la existencia de una materia activa que nos interpela y nos condiciona. 


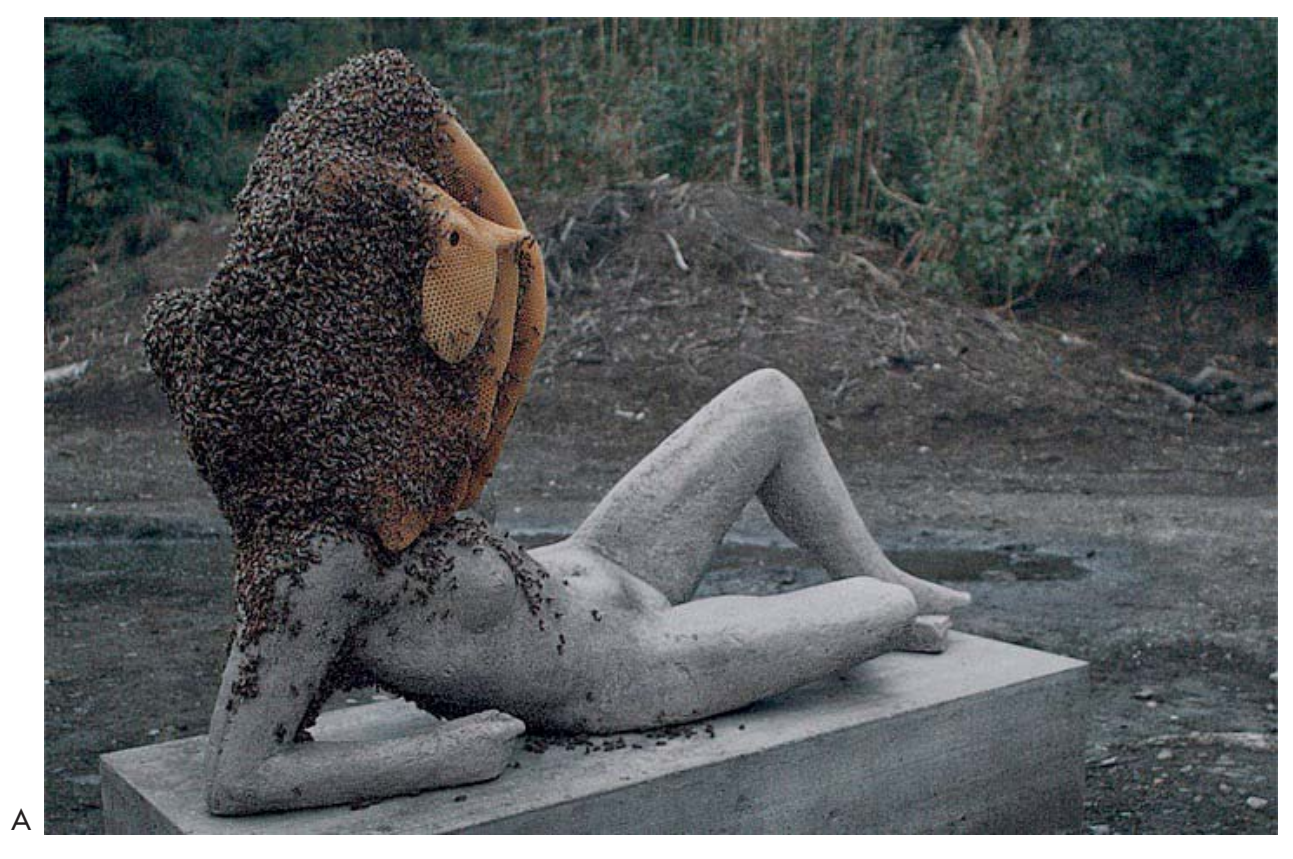


A. Pierre Huyghe. Untilled (Liegender Fravenakt) (2012).
La inteligencia se encontraría en jugar en el lado de las resistencias, como un velero, que las interpreta para ir contracorriente con mínima energía desviándose del destino si es necesario para reducir esfuerzos. El opuesto sería la de un barco a motor que, consumiendo recursos, es capaz de imponer su trayectoria, como siempre se ha dicho, contra viento y marea. No debe interpretarse este posicionamiento como una inhibición de las funciones del arquitecto o como una postura romántica hacia lo existente sino que por el contrario tiene que ver con una forma de actuar menos heroica, más cotidiana.

Habitar el mundo implicaría llegar a acuerdos y dejar que las partes se organicen bajo relaciones específicas y concretas. Deshacerse de la necesidad de la unidad del objeto para encontrar una vestimenta más cómoda en la multiplicidad. Permitir colonizaciones fragmentadas y oportunistas. En ese sentido el arquitecto adoptaría una actitud similar a las que Bourriaud asigna al artista en el mundo del arte:

"El artista habita las circunstancias que el presente le ofrece para transformar el contexto de su vida en un universo duradero" ${ }^{\prime 18}$

Todas estas características nos llevan a pensar en un imaginario que opera más cerca de las acciones de lo cotidiano, reorganizando y completando. Como el que reinventa el salón de su casa, aprovechando su conocimiento extenso sobre lo que tiene y aportando las piezas justas para movilizar de nuevo la ilusión por habitar. No se trataría de construir el lugar que habitamos desde cero, erradicando lo que quede en él, sino utilizar otra lógica, la de amueblar el mundo.

Amueblar el mundo es aplicar la coherencia desconectada del cuerpo distraído a la arquitectura; es dejar que lo que estaba allí y lo que se añade encuentren vínculos al mismo tiempo que muestran sus diferencias irreconciliables; es el espacio de relación y de complicidad que emerge cuando en la conversación todos los interlocutores se superponen al hablar; pero también es la forma en la que convocar imaginarios para deshacer el agotamiento afectivo de la materia que nos rodea sin hacerla desaparecer, sin que tengamos que erradicarla. 


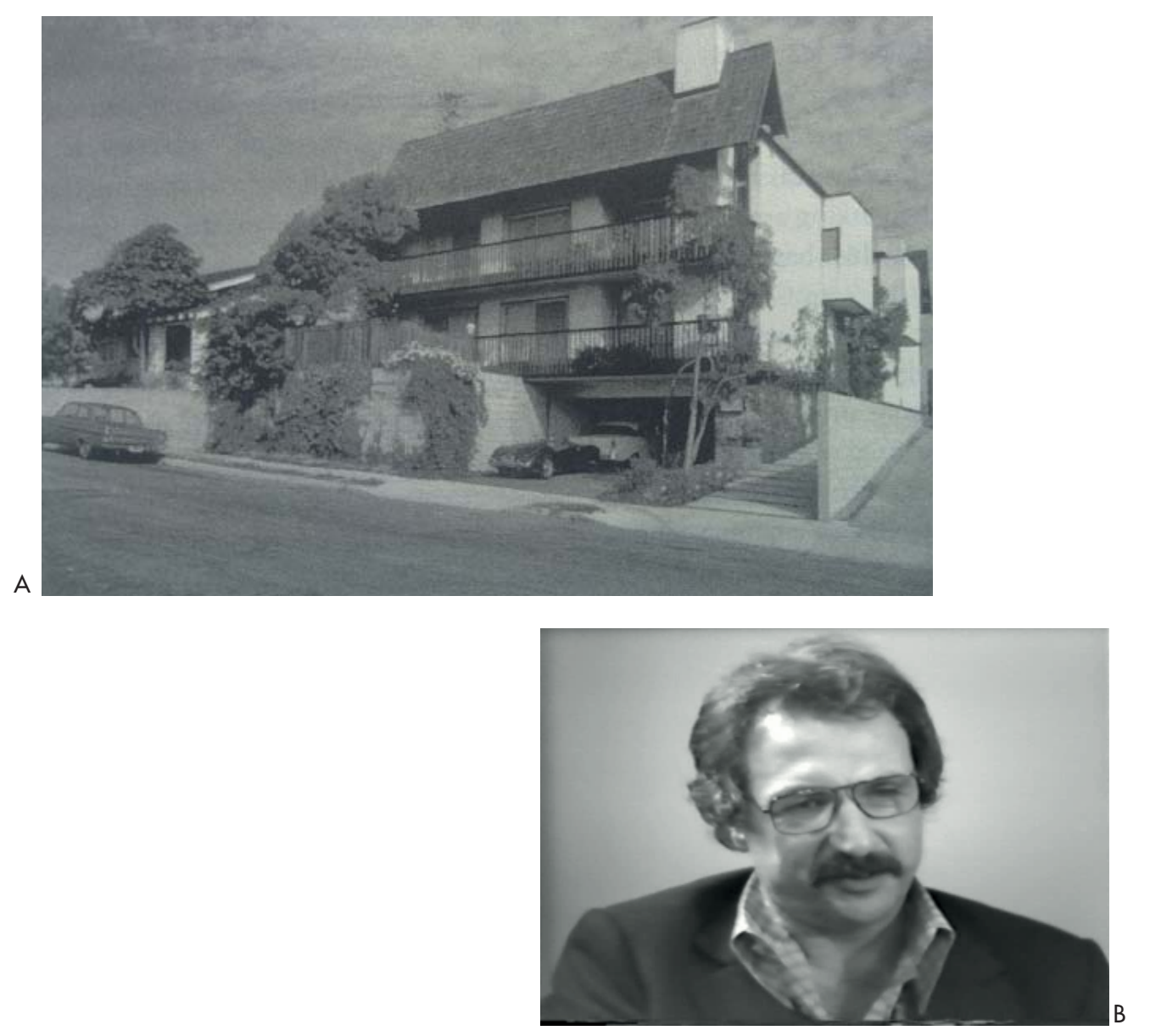




\subsection{DE LA CASA-ROSA A LA CASA-GEHRY}

A. Hillcrest Apartments en Highland Avenue, Santa Monica.

B. Frank Gehry (1929- ), 1977.
119. Frank Gehry contaba por aquellas fechas con dos hijas más, Leslie y Brina, de su anterior matrimonio con Anita Snyder.

120. De aquel proyecto Gehry diría: "I was trying to talk to the neighborhood and I didn't have a vocabulary to take it somewhere." En Goldberg, 2015: 123

121. Isenberg, 2009: 65
En 1977 Gehry y su mujer Berta Isabel Aguilera vivían, con su hijo recién nacido ${ }^{119}$, en los Hillcrest Apartments en Highland Avenue, Santa Mónica. Gehry había proyectado el edifico en 1964, su encargo más grande desde que se hubiera puesto por su cuenta. El edificio era poco llamativo, un bloque de dos plantas de estuco blanco con balcones corridos de madera y una cubierta a dos aguas que flotaba con aparente independencia sobre el conjunto. El estuco blanco y la madera recordaban vagamente a la arquitectura de Rudolf Schindler mientras que con la cubierta Gehry había intentado ser contextualita con el vecindario. Sin embargo, como el mismo reconoció, su resultado fue algo pobre y no muy significativo. ${ }^{120}$ Después de trece años en aquel apartamento, la familia Gehry decidió que era el momento de buscar un hogar más grande.

El bajo presupuesto con el que contaban y la falta de confianza de Gehry para diseñar su propia casa les llevó a pensar en comprar una y reformarla. Su idea era permanecer en Santa Mónica donde llevaban años viviendo. En la búsqueda Berta encontró una casa bien situada y en suave decadencia. El bungalow de estilo colonial holandés ocupaba una parcela en la esquina de las calles 22nd Street y Washington Avenue. Estaba ubicada en un barrio agradable de calles anchas con árboles y casas de una planta. La casa tenía una presencia anodina, más cercana a las casas de la costa Este que a las de estilo español que constituía el estándar básico de la ciudad. La compraron por 160.000 dólares y decidieron reformarla para ganar espacio:

"I told Berta I didn't have time to find a house, and because we liked Santa Mónica, she got a realtor there. The realtor found this pink bungalow on a corner which, at the time, was the only two-story house in the neighborhood. We could have moved in as it was. The upstairs part was large enough for our bedroom and a room for the baby. But it needed a new kitchen and the dining room was tiny-a little closet." ${ }^{121}$

El proyecto empezó con la idea de hacer una pequeña reforma que fuera capaz de alojar una cocina un poco más grande o de ser más segura para 


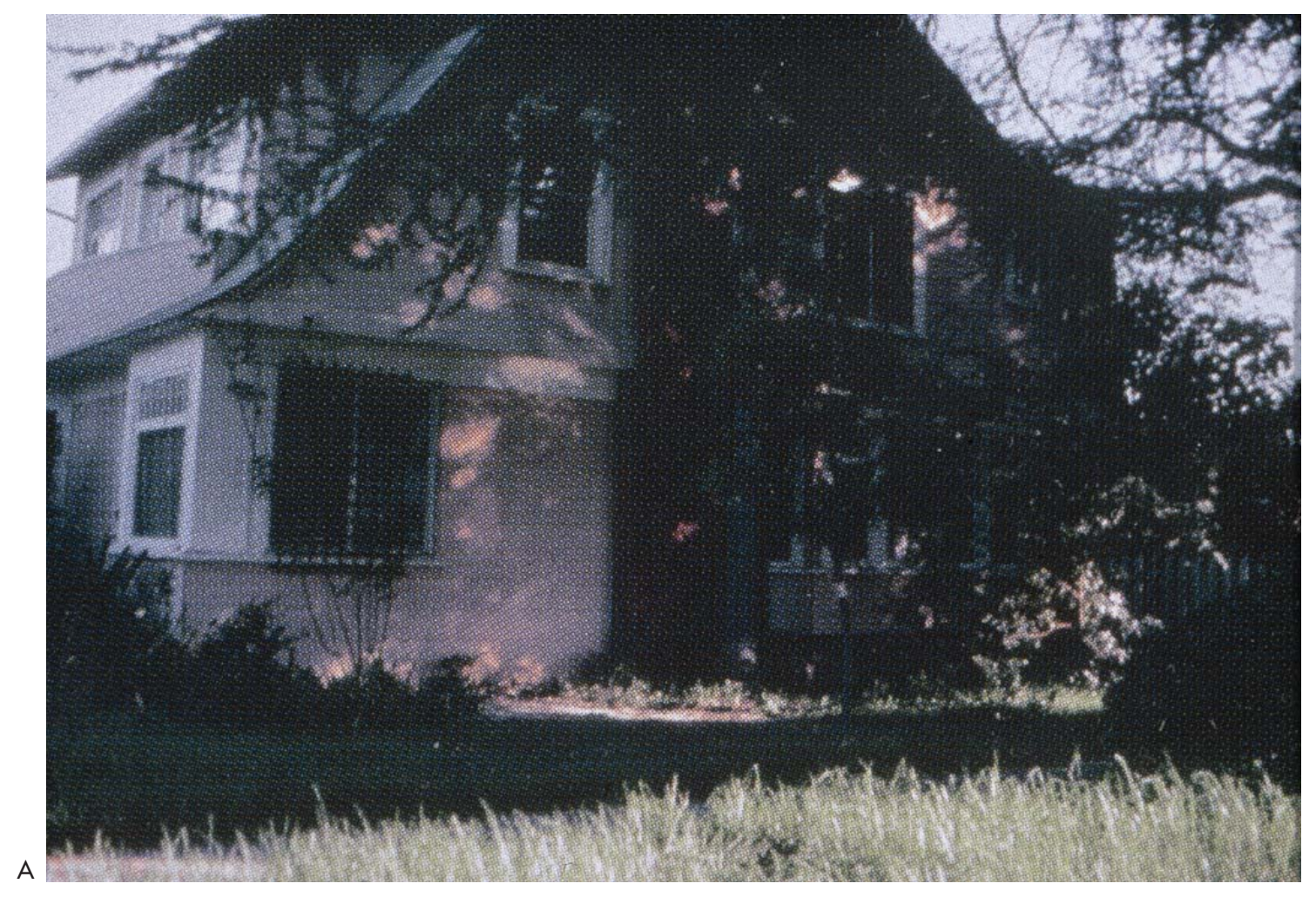


A. Casa rosa, Santa Mónica. Arquitecto anónimo antes de la erforma de 1978. that time we had one baby, Alejandro, who was hyperactive and running around all over the place. So safety was a major concern. The one staircase needed to be as safe as a staircase could be. And we needed a place for him to play-a backyard. I wanted a bigger kitchen than the one I had in the apartment where we were living. Those were my most important requests." Friedman, 2009: 65

123. Cobb, 1988: 34-36

124. Por aquellas fechas Gehry ya había empezado a colaborar con varios artistas y había construido las casas estudio para Lou Danziger (1965) y Ron Davis (1972). su hijo recién nacido ${ }^{122}$ pero en el proceso el diseño se fue complicando a medida que Gehry iba dándole vueltas. En otra entrevista Gehry se sincera y desvela la angustia que sintió al poco de haber comprado la casa:

"Recuerdo el proceso de diseño de esta casa; era antigua, la había comprado mi mujer para vivir y yo no lo veía posible por su insignificancia. Había que hacer algo. Yo allí era incapaz de vivir y, en cambio, era esa la intención de Berta." ${ }^{123}$

Quizá Gehry estaba agobiado pensando en lo que dirían sobre su nuevo hogar los artistas bohemios que había empezado a frecuentar y que le estaban encargando sus estudios y casas; ${ }^{124}$ o quizá sintiera que aquella casa era incapaz de aportar ninguna felicidad a la familia que empezaban a construir Berta y él. En cualquier caso, lo que desvela la cita de Gehry al describir la casa en términos de insignificancia es que la obsolescencia que se cernía sobre ella no era debida tanto a una insuficiencia funcional sino a un agotamiento emocional, a la incapacidad de movilizar su entusiasmo. Para Gehry el proyecto requería algo más que el arreglo de desperfectos y una nueva distribución y sin embargo Berta creía que podían vivir en aquella casa que habían comprado.

De alguna forma, el dilema en torno a la casa está describiendo exactamente el comportamiento frente al cambio de lo construido existente y nos permite poner a prueba y corroborar la Teoría de la Resistencia a los Imaginarios que hemos enunciado en el capítulo anterior. Aunque incidiremos con más profundidad en esta idea a lo largo de las siguientes páginas queremos de alguna forma poner de relieve la importancia de la misma a la hora explicar el proyecto de Gehry. Por un lado, tenemos al apego asociado a la materia: Berta se identifica con la casa que se había encargado de elegir sin la ayuda de su ocupado marido. Los afectos de Berta impregnan el antiguo bungalow y de alguna forma lo protegen de la destrucción. Por otro lado, la casa cuenta con su propia defensa, los componentes que la constituyen establecen su oposición estratificada según la jerarquía marcada por las técnicas constructivas y los materiales utilizados.

Gehry necesitaba una herramienta que diera sentido a esta especie de esquizofrenia: por un lado la necesidad de mantener en lo posible, siguiendo 

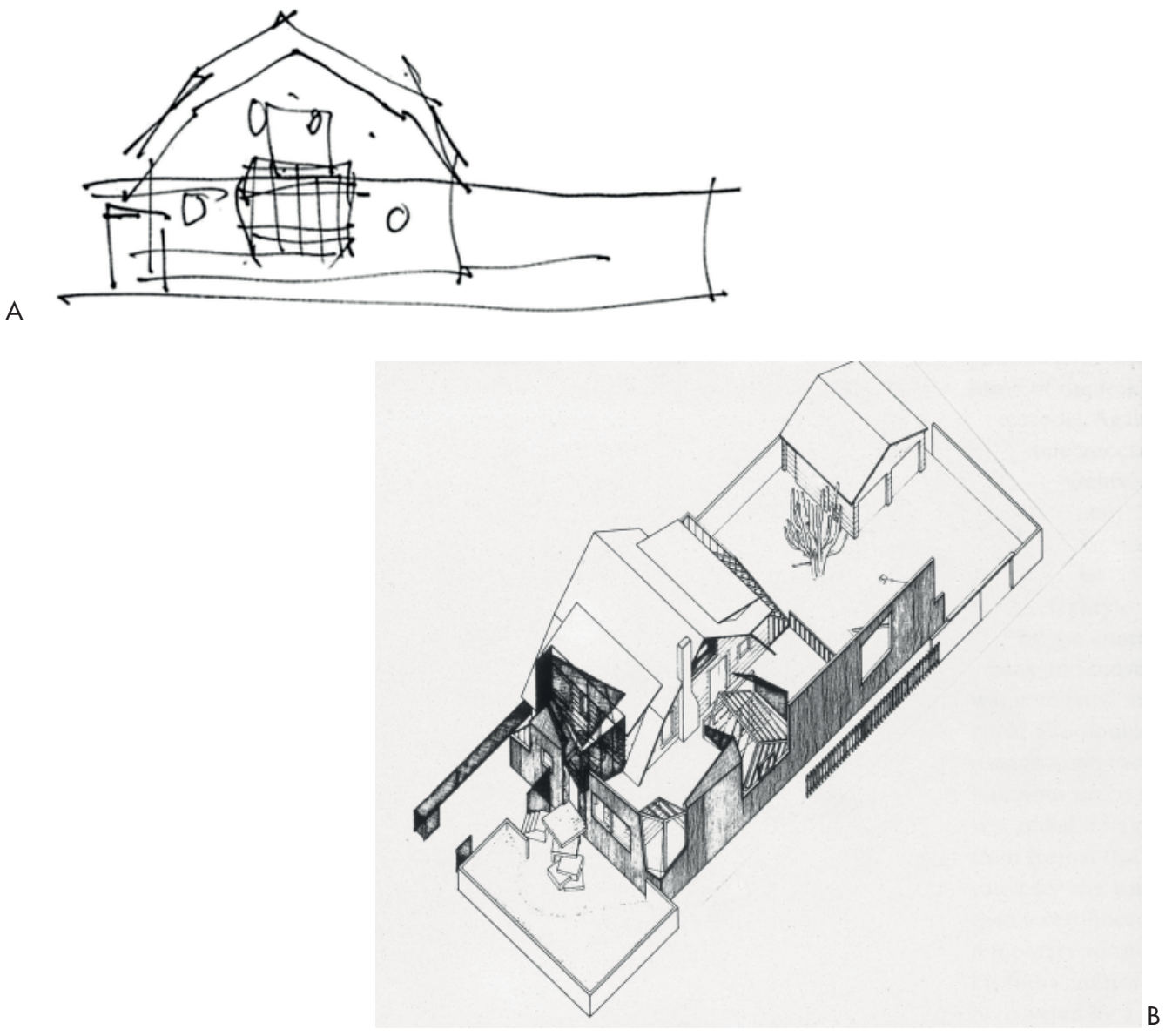
A. Frank Gehry. Maquetas.Croquis original de Santa Monica House (1978).

B. Frank Gehry. Axonometría de Santa Monica House. la voluntad de su mujer y también de su limitada economía, la integridad de la casa y por otro la necesidad de doblegar la banalidad de aquella construcción. Visto desde esta perspectiva, la decisión tomada por Gehry para desarrollar su proyecto es literalmente la que surge de la coexistencia de ambas inquietudes. El resultado puede entenderse entonces como una agrupación heterogénea, un cuerpo arquitectónico en el que cohabitan dos sensibilidades; dos mundos; dos casas.

"Provisto de poco dinero decidí construir una casa que envolviera a la antigua procurando conservar la tensión entre ambas por medio de la definición recíproca y de la sensación experimentada desde el exterior y el interior, de que la primera se mantenía intacta dentro de la nueva. Estos, que no otros, fueron los objetivos fundamentales."125

Estos eran los objetivos y no otros, sentencia Gehry: una casa dentro de otra. Un proyecto ideado como una dualidad que debía de ser percibida en todo momento, no solo desde la calle sino también desde dentro. La casa original fue rodeada por una nueva estructura de geometría irregular. Una construcción gamberra y desprejuiciada de montantes expuestos de madera, vidrio, chapa ondulada de acero galvanizado y malla metálica.

"Quería que la antigua casa quedara intacta dentro de la nueva para que se viera que aún estaba allí. Se notaría su presencia y que alguien la había envuelto con nuevos materiales, pero siempre, de día y de noche, podría contemplarse como si uno mirara por la ventana. Mi deseo fue que fruto de esta combinación ambas casas se enriquecieran mutuamente"126

El contraste con el estilo vernáculo del bungalow holandés era radical y su antagonismo se hacía explícito en todas las decisiones de la nueva casa. La adición no llegaba a tener nunca más de una planta por lo que era posible en todo momento ver asomar la casa original entre los quiebros y transparencias de la nueva. En el interior la dualidad se hacía explicita con aguda ironía, en algunos sitios se respetaba la fachada y ventanas originales a pesar de quedar ya en un interior, mientras que en otras zonas, se descarnaba hasta dejar el esqueleto de montantes de madera. La nueva extensión mantenía el nivel de la calle, por debajo del suelo de la casa original. Y para no dejar dudas de su 

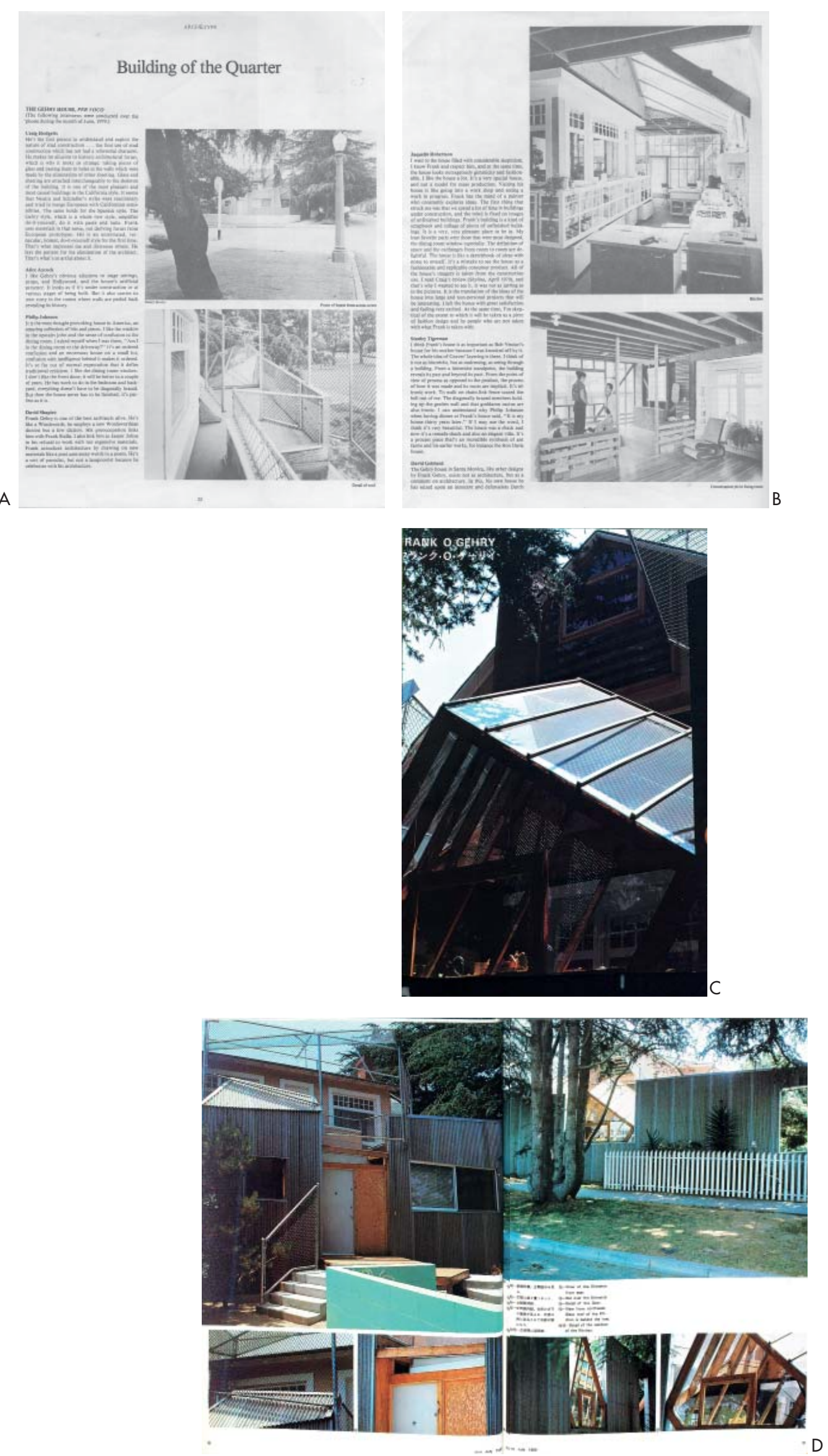
A. Building of the Quarter. En la revista Archetype. 1979, Vol. 1,2. Pág. 23.

B. Building of the Quarter. En la revista Archetype. 1979, Vol. 1,2. Pág. 24.

C. Architect's House. Santa Monica, California 1978. En la revista Architecture and Urbanism $A+U$. 1980, Vol. 7. Pág. 3

D. Architect's House. Santa Monica, California 1978. En la revista Architecture and Urbanism A+U. 1980, Vol. 7. Págs. 8-9 intención Gehry optó por un suelo de asfalto. La sensación era la de estar en un ambiguo "fuera" interior. El proyecto, como se puede apreciar, va mucho más allá de una simple extensión. Es a la vez romántico, macarra, cutre, sutil, irónico e indudablemente heterodoxo. Alcanzó un éxito inmediato y en pocos meses se convirtió en un lugar de peregrinación para arquitectos y artistas que, intrigados por aquel Frankenstein que levantaba tantas suspicacias como elogios, veían en él algo completamente nuevo. La misma fascinación nos ha impulsado a nosotros a elegirla, por un lado para entender los mecanismos de la duplicidad y la intervención sobre de lo existente, pero también por profundizar en las prácticas arquitectónicas.

A partir de ahora realizaremos una inmersión en el proyecto desde la perspectiva de la dualidad. Para ser fieles a la constitución de la casa y ser capaces de identificarla simultáneamente como un todo y una multiplicad se ha optado por asignarlas nombres diferentes. Para referirnos a la casa original utilizaremos, de forma intencionada, el nombre genérico y anónimo de "casa-rosa". Para denominar a la casa que surge de la acción del arquitecto californiano recurriremos al habitual "casa-Gehry". Por último, para nombrar al conjunto resultante de ambas, se ha recurrido el más explícito "totalidad-casa” o su versión geográfica "casa de Santa Mónica".

\subsubsection{La casa-rosa}

La casa que compraron los Gehry había sido construida hacia los años veinte del siglo pasado en un área residencial de Santa Mónica. La ciudad, aprovechando su condición costera, había empezado a crecer en la década de 1890 vinculada al comercio marítimo, del que fue poco a poco desligándose para acabar convirtiéndose en un centro de ocio y placer al que se desplazaban los habitantes de la cercana Los Ángeles. A principios de siglo se construyeron grandes muelles que sirvieron para alojar parques de atracciones y se creó un tejido residencial vinculado a la playa y a campos de golf. La bonanza económica del país en los años veinte se dejó sentir con fuerza en la ciudad que pasó de tener 15.000 a 32.000 habitantes al final de la década. En ese contexto de prosperidad es en el que la casa-rosa emerge como un ejemplo del crecimiento suburbial americano de aquella época. 

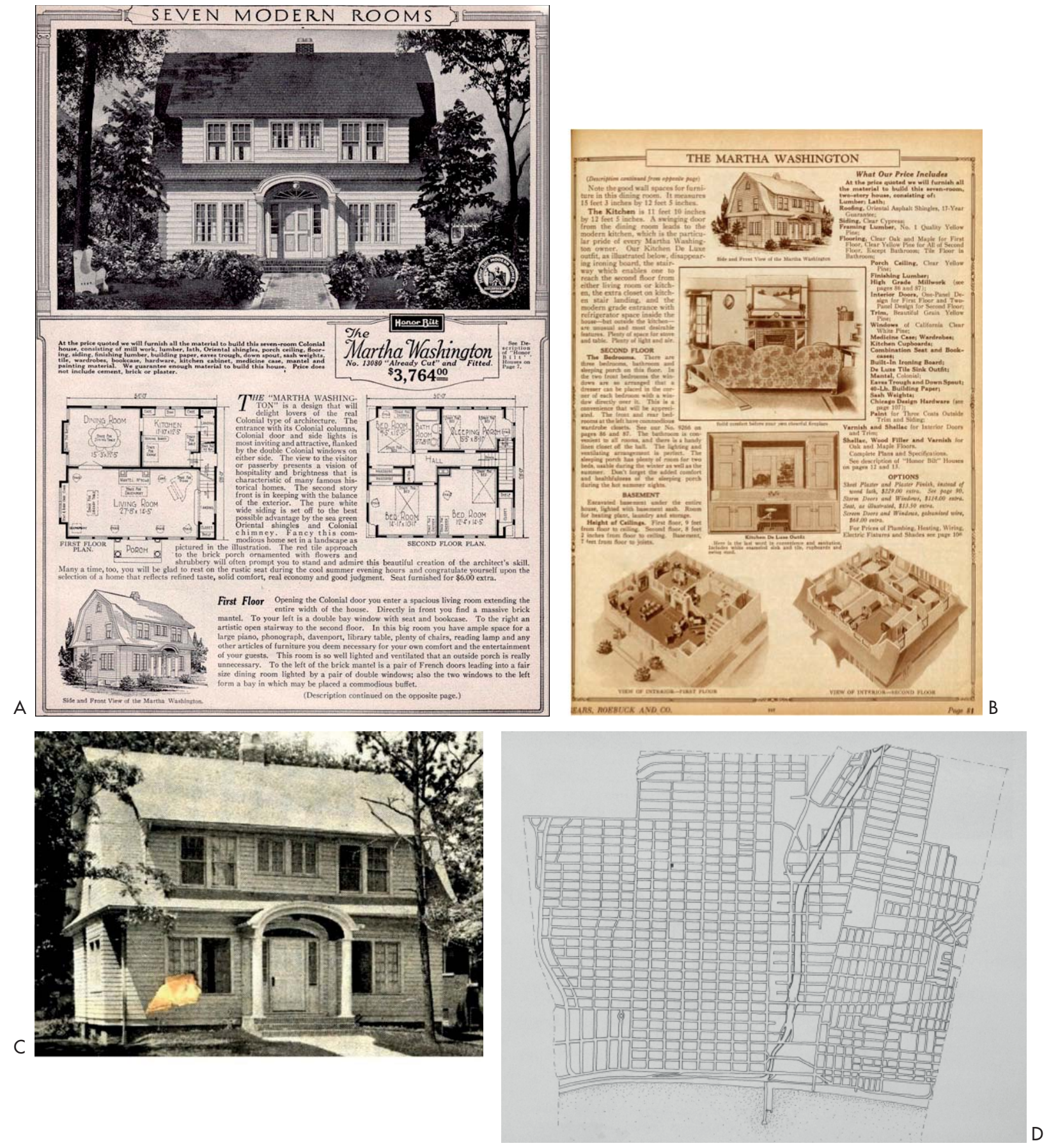
A-B. Marta Washington Houses. Publicidad con imágenes y planimetría de la vivienda. Años veinte. C. Marta Washington House. Años veinte. D. Plano de Santa Mónica con la localización de Santa Monica House.
La casa de paredes rosa marchito y cubierta de tejas asfaltadas era ordinaria pero no convencional, su estilo colonial holandés era extraño incluso para una ecléctica Los Ángeles. Detalles como su cubierta abuhardillada la convertían en una rara elección dentro del paisaje doméstico californiano. Y decimos elección porque seguramente su origen se deba precisamente a una elección. En Estados Unidos era habitual que, por aquellas fechas, las casas se hicieran según catálogo. Había diversas empresas que ofertaban modelos con diferentes estilos para satisfacer el gusto de los clientes. Las fichas de las compañías aportaban una imagen exterior, unas plantas y un texto descriptivo. El modelo "Verona" ofertado por la empresa Honor Bitt te permitía tener una casa de estilo holandés pre-cortada y lista para montar por 4.096 dólares. Por un poco menos, 3.764 dólares, el modelo "Marta Washington" ofrecía una vivienda de dos plantas con todos los complementos que un amante del diseño colonial pudiera imaginar:

"The "MARTHA WASHINGTON" is a design that will delight lovers of the real Colonial type of Architecture..... the view to the visitor or passerby presents a vision of hospitality and brightness of many famous historical homes....Many a time, too, you will be glad to rest on the rustic seat during the cool summer evening hours and congratulate yourself upon the selection of a home that reflects refined taste, solid comfort, real economy and good judgment."

Quizá, más allá del estilo de la casa, la mejor decisión de los compradores originales tuvo que ver con la elección del solar. La parcela se ubicaba en la confluencia de Washington Avenue, que nace perpendicular a la costa y sigue la orientación suroeste-noreste, y la 22nd Street, que la acomete perpendicularmente. Lo original del encuentro es que la 22nd Street interrumpe su trazado lineal mediante un ligero quiebro y crea una discontinuidad en la rígida retícula de Santa Mónica lo que aporta una perspectiva singular a la casa. La construcción quedaba aislada en la parcela, dejando un pequeño paso con la parcela vecina en el sureste y un jardín interior al suroeste. La fachada principal se situaba en el lado corto de la parcela dando a la 22nd Street, por donde tenía el acceso. La vivienda era de dos plantas y contaba con una buhardilla. El acceso no estaba a nivel de calle por lo que para acceder era necesario subir algunos peldaños. 

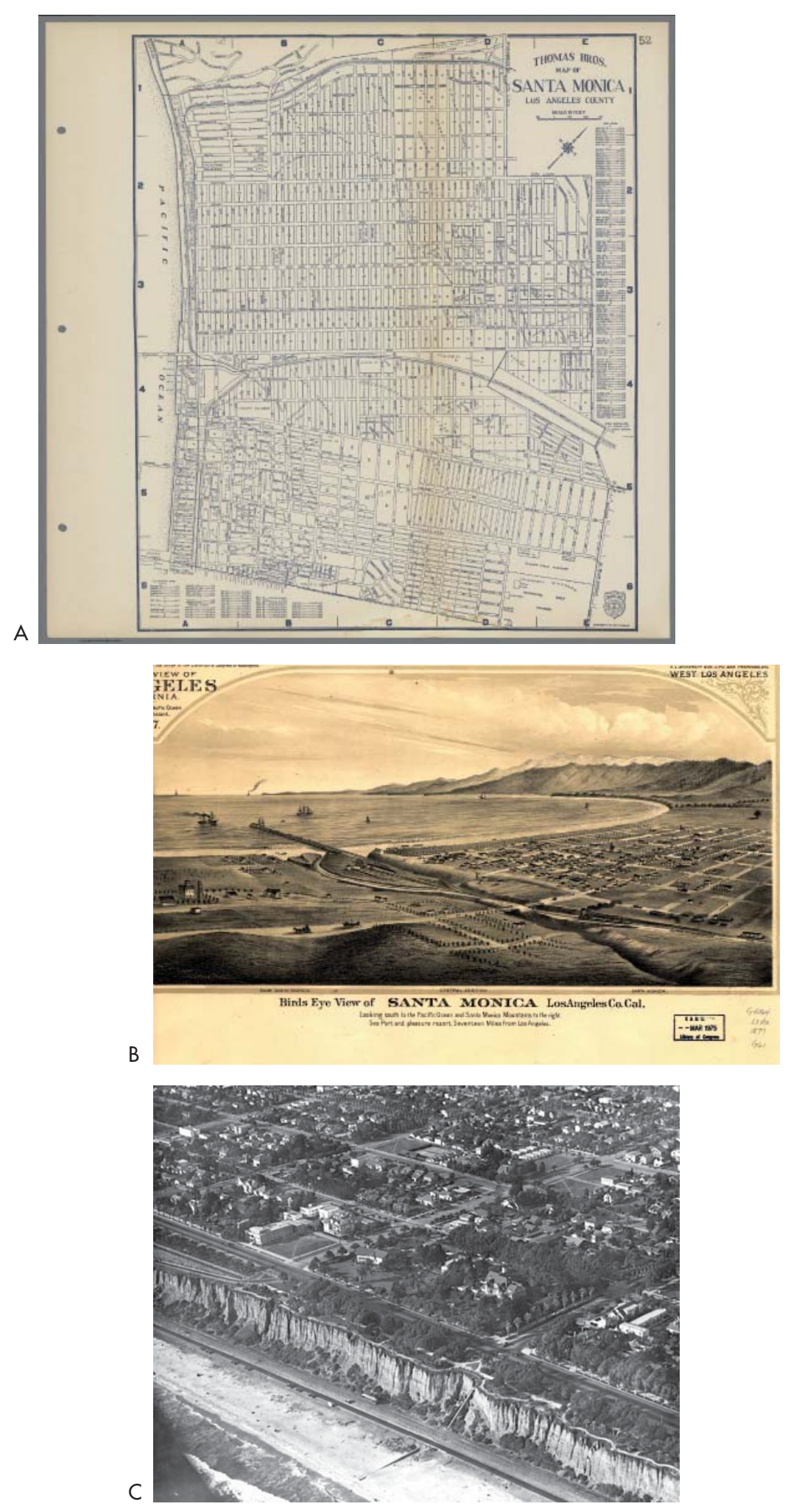
A. Plano de Santa Mónica.

B. Vista de pájaro de Santa Mónica. Con la inscripción inferior: Looking south to the Pacific Ocean and Santa Monica Mountains to the right. Sea Port and pleasure resort, Seventeen Miles from Los Angeles. (1877).

C. Foto aérea de Santa Mónica tomada en los años veinte.
La distribución era relativamente convencional y contaba con algunos detalles típicos de las construcciones residenciales americanas como la bow window o el pequeño porche de acceso. La gran pendiente de la cubierta marcaba los alzados de la casa. El tejado a dos aguas volcaba sobre las fachadas cortas quedando la cornisa al nivel del suelo del primer piso lo que hacía que las habitaciones de la planta superior tuvieran contacto con el exterior a través de una mansarda. La fachada contraria era más tersa y solo quedaba alterada por un mirador en planta baja y por una chimenea de ladrillo rojo que ascendía por el exterior resaltando con su verticalidad la singular doble inclinación de la cubierta. En el exterior, unos cedros del Líbano de gran porte plantados en el ajardinamiento de la acera daban cierta privacidad a la fachada noroeste. En el patio trasero una euphorbia que había llegado a tener una altura considerable era una bella pieza que recordaba, en contraste con los cuidados jardines de césped del vecindario, la cercanía del desierto y el brutal paisaje californiano que hasta no hacía mucho todavía llegaba allí.

Profundizar en el ADN constructivo de la casa-rosa también es importante para entender la estrategia seguida en el desarrollo de la obra y sin duda determina muchas de las soluciones que Gehry iba a adoptar en torno a ella. La obra original pertenecía a la tradición americana del balloon frame, un sistema constructivo basado en un entramado estructural de montantes de madera de sección pequeña que, distribuidos de forma regular y cada poco, generan una urdimbre conectada y estable.

El sistema había nacido a finales del siglo XIX en la ciudad de Chicago para facilitar la construcción de edificios de pequeña escala como una alternativa más rápida y menos costosa a otros sistemas más sólidos como los del ladrillo o los de pesados postes de madera. Al principio se utilizó solo como acabado de las casas pero poco a poco fue convirtiéndose en un sistema portante capaz de resolver arquitecturas complejas. Aunque al inicio su fragilidad y carácter efímero levantaba suspicacias -de ahí su nombre-con el tiempo fue adquiriendo aceptación. La construcción se fue sofisticando, se aligeraron las partes masivas y se ganó manejabiliad y facilidad de transporte. El sistema alcanzó una rápida implantación motivada por la posibilidad de utilizar trabajadores poco especializados y como resultado de una extensa industrialización de la madera aserrada. La construcción 

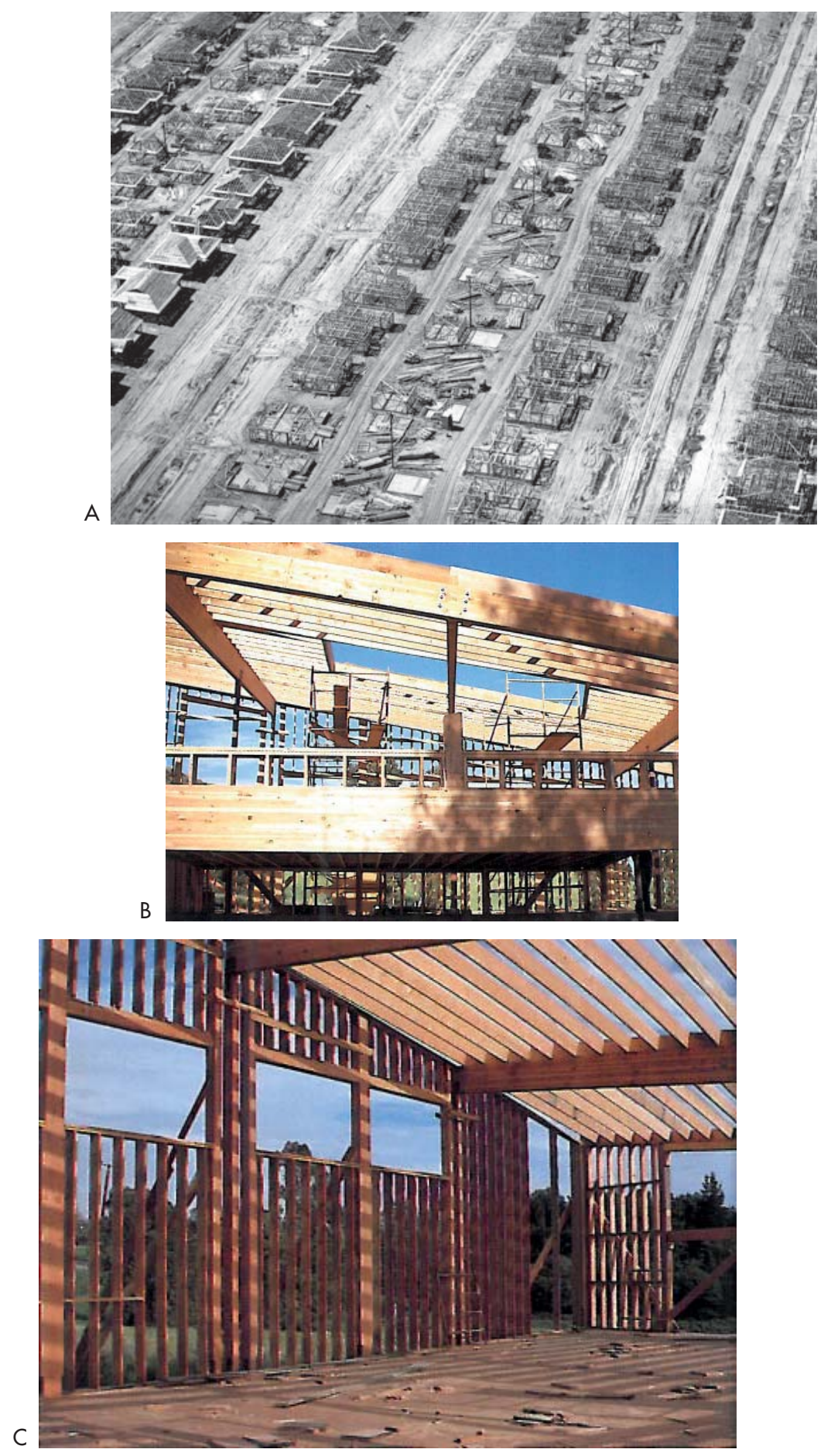
A. Lakewood Park House Frames, 1950. Fotografía de William A. Garnett.

B-C. Frank Gehry. Ron Davis House (1972). Sistema constructivo Balloon frame. fue posible cuando los clavos fueron finalmente producidos mecanicamente permitiendo un precio sensiblemente menor y garantizando la resistencia y durabilidad. Otra contribución básica fue la evolución de la maquinaria en las serrerías que en pocos años alcanzaron un nivel de producción muy alto." Véase Rubino, 1984.

128. Forster, Gehry y Bechtler, 1999: 14 permitia, con el simple uso de clavos, ensamblar materiales diversos en múltiples configuraciones sin necesidad de incorporar a otros gremios. ${ }^{127} \mathrm{El}$ sistema no solo facilitaba el montaje sino que permitía acelerar los ritmos de producción por lo que pronto se convirtío en el patrón constructivo habitual de los Estados Unidos. Como varios autores han indicado, fue en realidad el sistema que permitió el crecimiento de las ciudades americanas al ritmo que la economía demandaba. La casa-rosa fue uno de los miles de ejemplos de vivienda hechos de madera pintada, inmersa en los alienados suburbios de casa pequeñas entre autopistas, que dio lugar a la eclectica metrópolis de Los Ángeles.

\subsubsection{La casa-Gehry}

Como muchos han apuntado Gehry no es muy dado a hablar de sus proyectos y menos a teorizar sobre ellos. Sus memorias son cortas y sus comentarios se repiten en tantas entrevistas y textos que es dificil saber si es la inercia de los criticos la que hace que todo suene parecido o es el propio Gehry que a base de contar las mismas anécdotas acaba construyendo un deja vu entorno a ellas. En cualquier caso, si se tiene la oportunidad de eschucarle o leerle es facil seguir sus argumentos. Sus comentarios son claros y precisos, siempre directos. Elude citar ideas o a pensadores canónicos y prefiere responder con algún acontecimiento o anécdota en torno al tema.

Para algunos, como Kurt Forster, Gehry nunca ha renunciado a hablar de su trabajo pero es reticente a "teorizar" sobre él, quizá porque eso sería usurpar el lugar de la obra misma. Por eso prefiere improvisar relatos que, según Forster, deben ser interpretados como alegorías:

"they are allegorical in the original sense of "saying it another way", for only that other way can make the point of the story. In his tales Gehry aspires to an architecture just as filled with thought as his fish are gefüllt with experience" 128

Para otros las anécdotas de Gehry son una tapadera, una especie de plan oculto cuya misión es crear una barrera de humo espeso para no dejar ver. Beatriz Colomina, una de las defensoras de esta aproximación, sostiene en su artículo "La casa que cosntruyó a Gehry": 

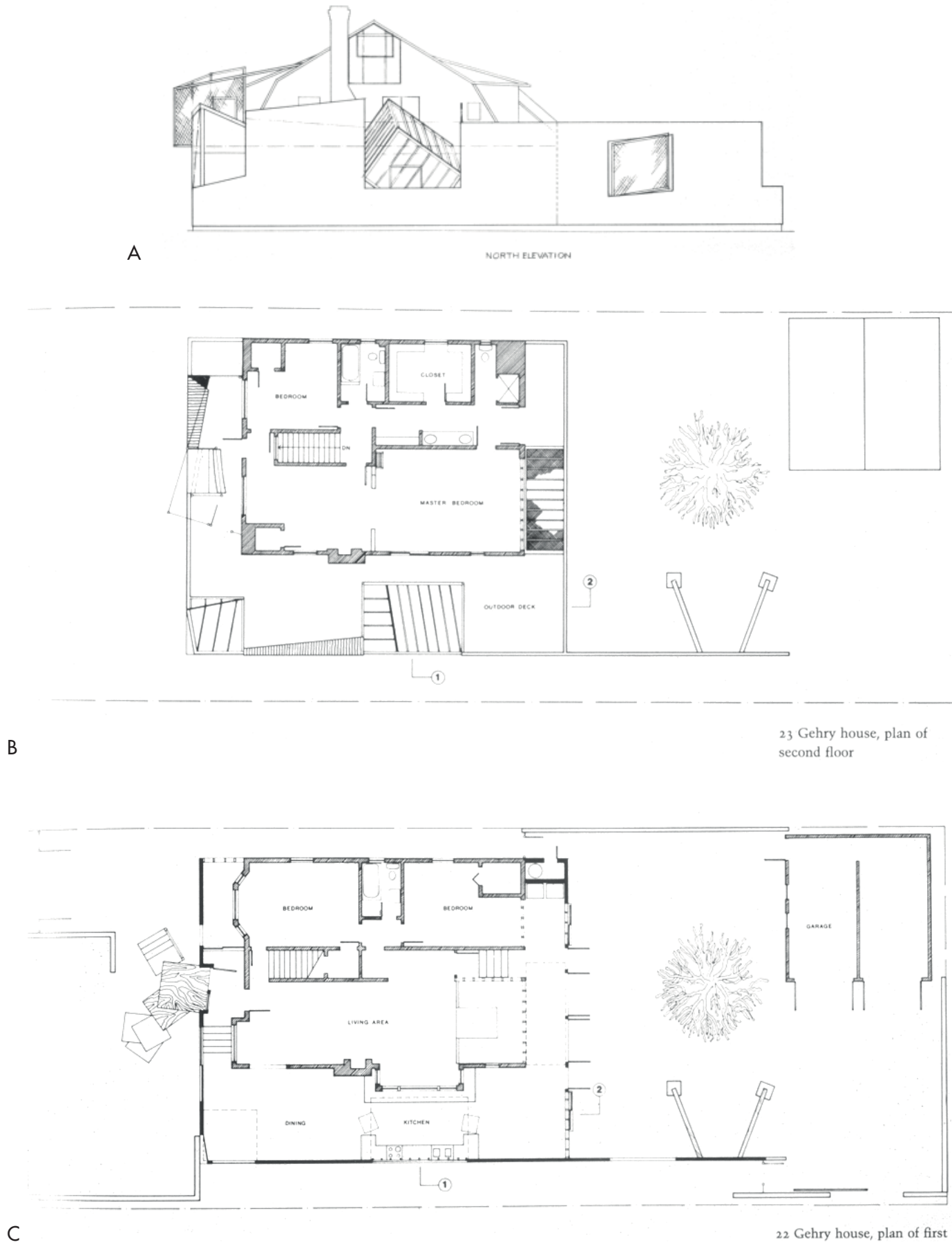
A. Frank Gehry. Santa Monica House (1978) Alzado norte.

B. Frank Gehry. Santa Monica House (1978) Planta superior.

C. Frank Gehry. Santa Monica House (1978) Planta inferior.
"Los críticos no ven más que lo que Gehry quiere que vean." ${ }^{129}$ e insiste "El mismo Gehry alimenta la visión de que la arquitectura puede practicarse al margen de la teoría.... Por supuesto, tan inocente como finge ser no es. Sólo vemos lo que él quiere que veamos." ${ }^{\text {"130 }}$

Quiza estas afirmaciones puedan ser ciertas y Gehry oculte mediante mascaras o parábolas sus intenciones. Pero también podemos pensar que, cuando construyo su casa, Gehry no era todavía el arquitecto que es hoy en día y quizá no había tenido tiempo para pensar en alegorías o en un plan para autoconstruirse. Podemos especular con que el éxito le sobrevino de repente, aunque lo estuviera buscando, y que para salir del paso dijo lo primero que le venía a la cabeza atragantado, como estaba, con la atención que había levantado su casa. Pensemos que fuera así, por lo menos al inicio de su carrera, y hagamos el ejercicio de interpretar de formal literal y sin prejuicios sus palabras.

Como cuenta el propio Gehry, a la adquisición de la casa le siguió un proceso de gestación de varios meses en las que desarrolló diferentes ideas, siempre en torno a envolver una casa dentro de otra, según una idea aplicada en un proyecto anterior:

"El precedente conceptual [...] está en la casa St. Ives; nos encontramos con una edificación existente y la rodeamos con otra. En aquel caso, la parte nueva armonizó estilísticamente con la antigua, no se produjo contraposición alguna, pero si una estratificación. Presiento que si no llego a dar ese paso no hubiera dado el siguiente"131

En una conversación con Barbara Isenberg Gehry volvía a recordar:

"I started working on its design and got excited about the idea of building a new house around the old house. Nobody realizes I had done the same thing a year before in Hollywood, when the office was out of work. We figured we could both create work and make money. We had all chipped in and bought the house, then remodeled it. We built a new house around the old house, and the new house was in the same language as the old house. I liked that idea and I 

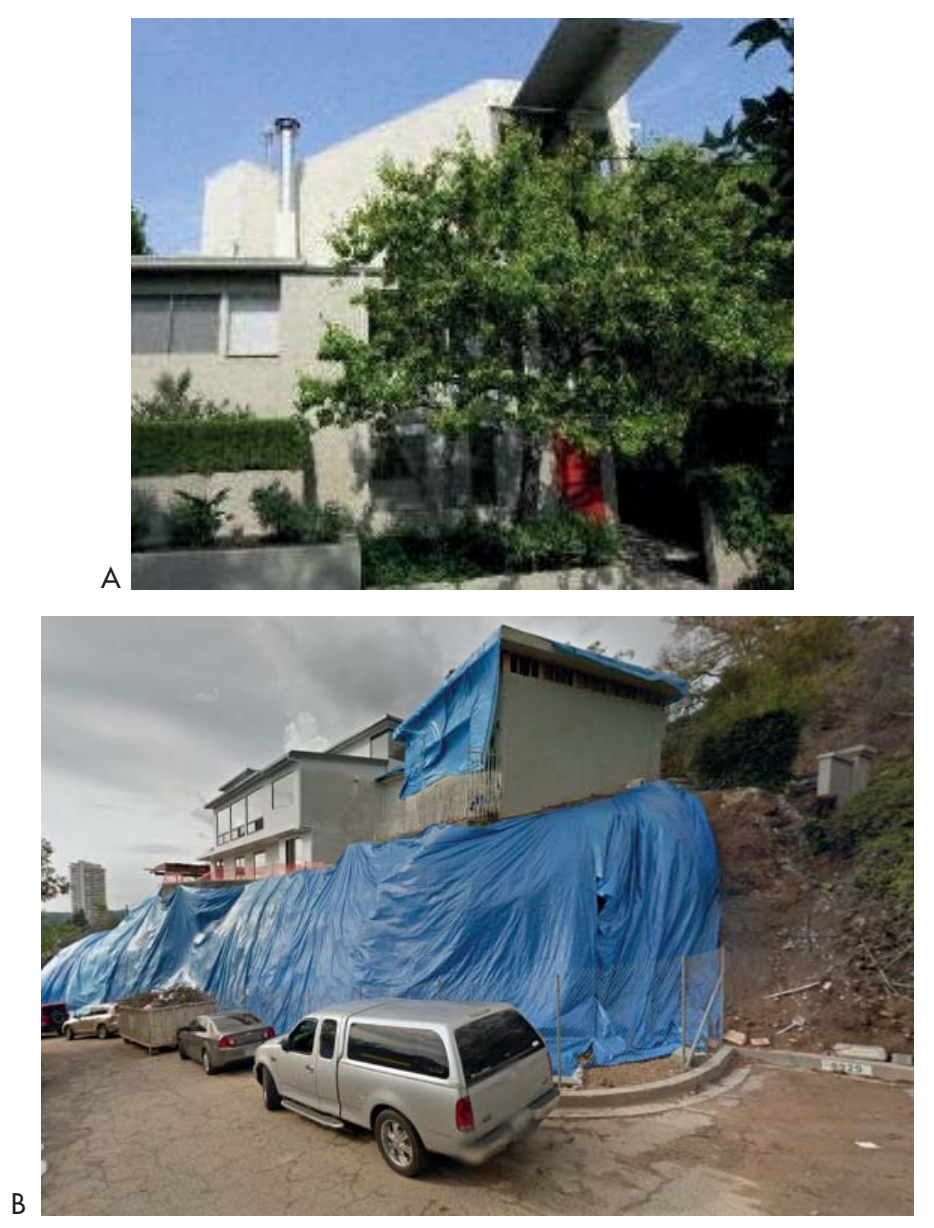
A. Frank Gehry. Reforma y expansión de un apartamento en el 8952 de St. Ives Drive (1976). B. St. Ives Drive hoy en día. hadn't really explored it enough, so when I got this house, I decided to take that idea further." ${ }^{\prime 132}$

La reforma y expansión de este apartamento situado en el 8952 de St. Ives Drive en Hollywood se realiza en 1976, un año antes de empezar la suya. Más allá de citarla como un precedente, el propio Gehry nunca ha prestado mucha atención a esta obra, ni ha sido publicada en libros, revistas o monografías. Existe poca información de ese apartamento salvo que la pieza original era una casa moderna de estuco blanco y que allí vivió una vez el actor Al Pacino. La reforma de St. Ives Drive no explica si la idea de la adición cobró una vida antes de su materialización en la casa-rosa. Parece evidente que el valor que le da es testimonial, el de marcar un giro casual, pero no contiene los imaginarios que habían de movilizar la nueva casa. Puede que en esta reforma estuviera la chispa, pero si de algo estamos seguros es que allí no estaba la leña.

La casa de Santa Mónica forma parte de un conjunto de obras más experimentales que marcan un cambio de actitud en el trabajo de Gehry de aquella época. Algunos críticos lo han vinculado a la fascinación y "contaminación" del mundo del arte. Kurt Forster ${ }^{133}$ recuerda que cuando Gehry era un estudiante, los artistas representaban algo parecido a una encarnación mítica de la libertad personal en la cultura Americana. El dinero podía comprar la independencia, la política asegurarte el poder y Hollywood darte visibilidad y la fama, pero ninguna de esas conquistas compensaba el gran sacrificio que suponía para la creación. Solo los artistas parecían capaces de obtener las ventajas de todo aquello sin renunciar a su libertad.

A mediados de 1960, Gehry entró en contacto con los artistas jóvenes de Los Ángeles. Eran frecuentes sus visitas a Venice y Ocean Park, barrios donde estos solían vivir y trabajar. Encontraba el trabajo de artistas como Billy Al

Isenberg, 2009: 65

Forster, Gehry y Bechtler, 1999

Literalmente Gehry se incorporó al

134. Literalmente Gehry se incorporó al y cuyo explicito nombre era Five Bags of Shit. El quinto artista podía variar entre Ken Price o Sam Francis. James Turrell también solía estar en los ensayos pero nunca tocaba. Gehry comentaba con ironia: "My instrument was bicycle handlebars tha had a ringy-ding bell, then I graduated to a toile plunger in a pail". Drohojowska-philp, 2011: 177 Bengston, Ed Moses, Ed Ruscha, Ken Price, Robert Irwin, Ron Davis, Tony Berlant, Larry Bell, Peter Alexander, and John Altoon más atractivo que el de los arquitectos contemporáneos. Su relación se fue haciendo próxima y no tardó en hacerse un hueco en el grupo. ${ }^{134}$ Para Gehry más allá de ser unos inmejorables colegas de juerga eran un reflejo de lo que ansiaba para sí mismo: 


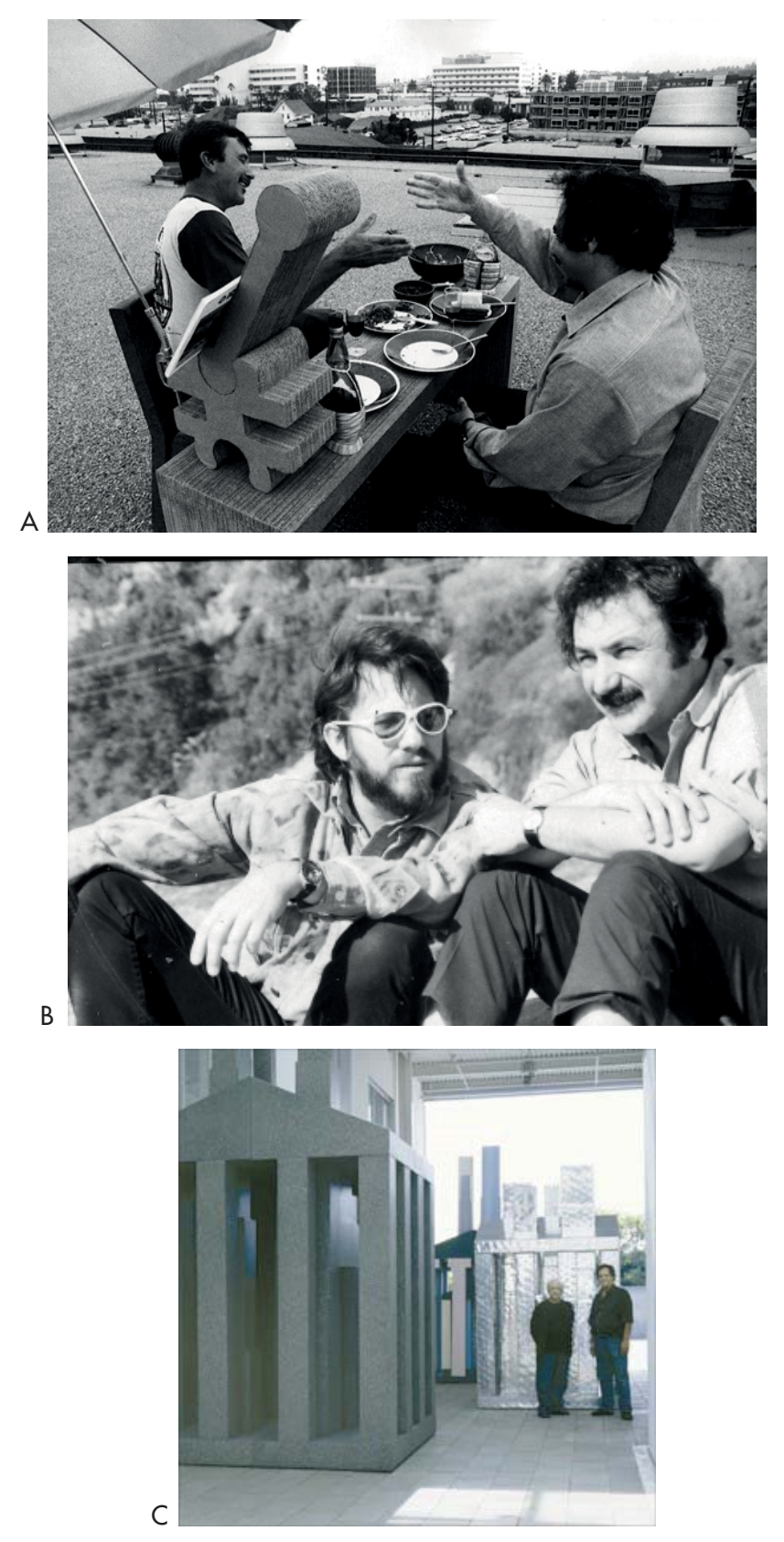


A. Billy Al Bengston y Frank Gehry en la cubierta de la oficina de Gehry en Santa Monica, ca. 1970.

B. Frank Gehry y Ed Moses, años 70.

C. Frank Gehry y Tony Berlant, años 80.
135. Isenberg, 2009: 58

136. Entrevista a Chuck Arnoldi en

Goldberger, 2015: 132-133

137. Colomina, 2006: 125
"Their work was more direct and in such contrast to what I was doing in architecture, which was so rigid. You have to deal with safety issues- fireproofing, sprinklers, handrails for stairways, things like that... When I got close to these guys. I'd hang out at their studios and watch them work and observe how they dealt with things, and it was very different. I was terribly enamored with directness of it and the Mount Everest-ness of it, how they had to confront a white canvas. That whole process seemed so much more likely to produce beautiful work than architectural process did. I knew pragmatic things had to be taken care of, and I could do that, but it wasn't enough"135

Chuck Arnoldi, artista y amigo cercano a Gehry, ha contado como fue el encuentro con Gehry. La escena artística de Los Ángeles en aquella época era muy pequeña, todo el mundo conocía a todo el mundo. Gehry tenía la reputación de comprar arte, lo que al principio le hizo muy atractivo para los artistas porque por aquellas fechas nadie vendía nada. Pero en realidad lo que hizo que se hiciera un hueco fue que él se sentía uno de ellos. "He was interested in what we were doing. Anybody that was interested in what you were doing was just immediately, you know, taken into scene, because there was no, there wasn't a big audience.”136 Gehry era feliz con aquel grupo y se sintió halagado cuando muchos de ellos se empezaron a interesar por su trabajo. Con el tiempo le fueron encargando algunos trabajos, proyectos en los que se permitiría explorar nuevos territorios como la casa estudio para Lou Danziger (1965) o la extensión para Gemini G.E.L. en 1975.

Beatriz Colomina afirma que "para Gehry, los artistas son ante todo modelos a imitar debido al envidiable control que ejercen sobre su obra. Algunas cualidades específicas de su casa las atribuye a la influencia de artistas o movimientos específicos." ${ }^{137} \mathrm{Y}$ cita, como demostración, la anécdota que el arquitecto cuenta sobre la ventana del comedor, que se descuelga intentando crear el efecto dinámico del Desnudo bajando la escalera de Duchamp, o como los juegos de malla metálica de la cubierta se parecen a la obra de tramas superpuestas de Brice Marden. En realidad hay múltiples obras y artistas que podrían invocarse como influencia de la casa de Gehry, pero son tantas y tan diferentes que sería ingenuo pensar que todas ellas forman una influencia común y unitaria sobre la casa. Las interpretaciones que identifican su origen 

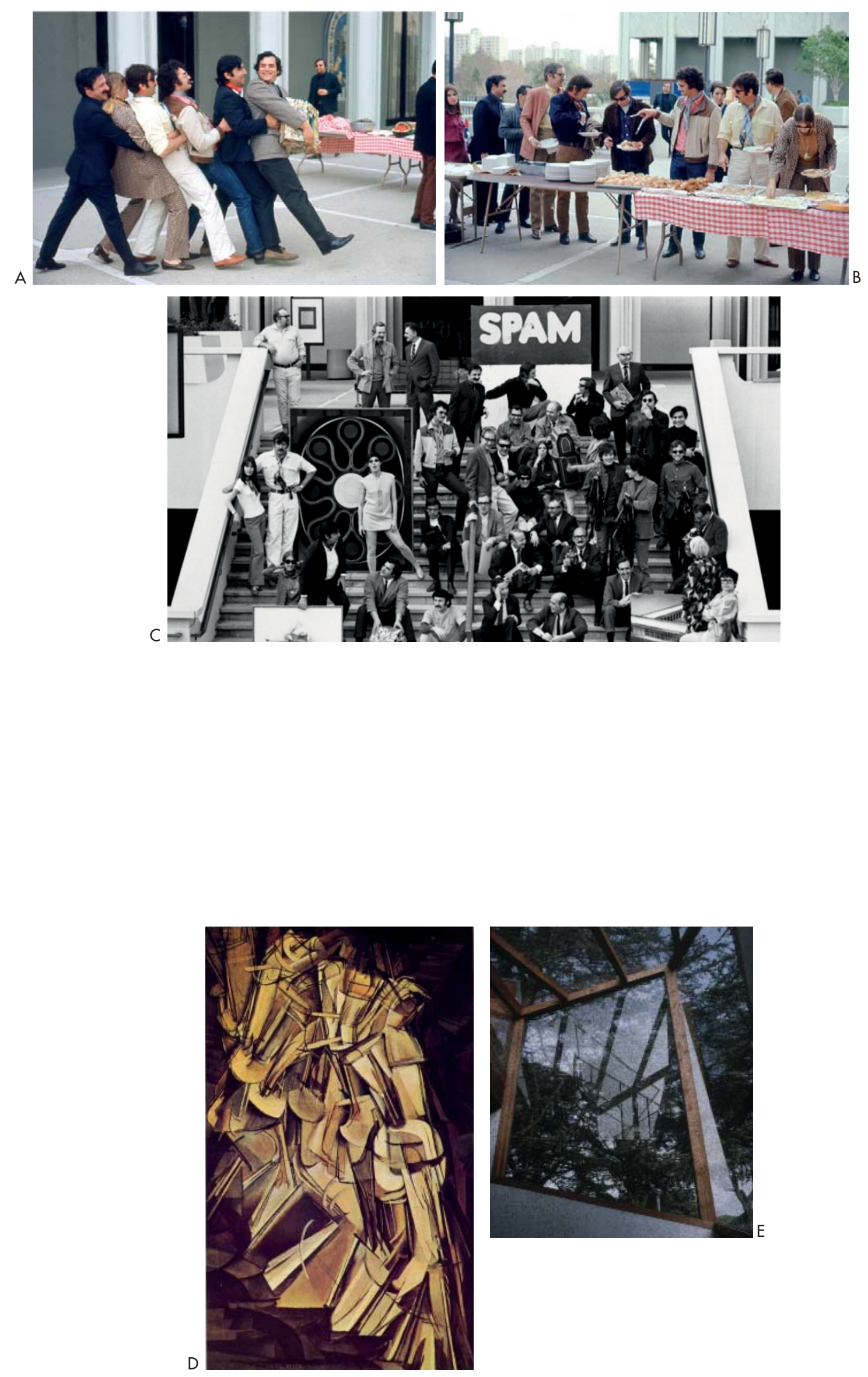
A. Frank Gehry, Babs Altoon, Billy Al Bengston, Larry Bell, John Altoon y Tony Berlant en Culture Day en el LACMA (L.A. County Museum of Art), 1968

B. rank Gehry, Ed Ruscha, Ken Price, Larry Bell, Billy Al Bengston, Babs Altoon, comiendo en Culture Day en el LACMA (L.A. County Museum of Art), 1968 .

C. En orden alfabético: Babs Altoon, John Altoon, Larry Bell, Billy Al Bengston, Tony Berlant, Leon Bing, Judy Chicago, John Coplans, Lou Danziger, Jules Engels, Frank Gehry, Rudi Gernreich, Lloyd Hamrol, Craig Kaufmann, ... en el LACMA IL.A. County Museum of Art), 1968

D. Marcel Duchamp. Nu descendant un escalier. (Desnudo bajando una escalera) (1912).

E. Frank Gehry. Santa Monica House (1978) Fotografía del interior.
138. Isenberg, 2009: 58
139. Goldberger, 2015: 134
140. Sirva como ejemplo de estas

$140 . \quad$ Sirva como elastas espacio que Larry Bell tenía en Market Street en Venice: "And in the dining room, there weren't just pictures on the walls. There was a hole in the wall where you sow the studs inside, with glass on either side. So you were looking at the wood studs as if they were a picture, and I loved that." Este mismo detalle lo utilizará en la ventana de su dormitorio en la segunda planta. Isenberg, 2009: 59

141. Drohojowska-Philp Cuenta la historia de forma ligeramente diferente y con dos origenes: "Bell had not covered the plumbing pipes in his bathroom with plaster but with glass. Moses had applied a similar solution to the dining room of art collector Laura Stearns by extending the glass of a window over the exposed studs in a wall. These examples led Gehry to leave the studs exposed in his work and to start using chain-link as fence as a building material." Drohojwska-Philp, 2011: 177

142

Friedman, 2009: 66 con el arte coetáneo conducen por lo general a comparaciones formales. Incluso lecturas críticas simplificadas interpretan con literalidad que las geometrías quebradas y las formas inestables son, por sí mismas, una práctica artística. En cualquier caso el propio Gehry se encarga de desmontar esa afirmación:

"The way these artists thought and approached making things was a lot more intuitive and in touch with who they were. It seemed that was the way to find your voice not the way I had been doing it. So I started mimicking their process, which was hard to do in architecture. And of course now you can see where it led.”138

A Gehry lo que le interesaba de los artistas más allá de su obra concreta o de sus hallazgos formales- que no dudaría en "robar" como el artista Billy Al Bengston afirmaría llamándole "the best thief of all time"139- era la manera en la que se aproximaban a hacer las cosas. ${ }^{140}$ Por eso comenzó a imitarles, pero no tanto en lo objetual sino en algo mucho más difícil y también con mucho más recorrido: empezó a entender los procesos que tenían lugar en la creación de las obras de los artistas.

"I was trained by Rudy Baumfeld, a Viennese architect who was Victor Gruen's partner. He did all this extraordinary detailing, the sort they do in Vienna. He was a perfectionist. He drove me crazy. But he trained me for five years, so I was trained very well. At that time Rauschenberg was making 'combines'; Jasper was doing what he was doing. My friends Ed Moses and Larry Bell and Billy Al Bengston were doing their thing. It wasn't fussy and finicky, and it was so beautiful. So I said to myself at that period, 'If I like all of this stud and if people are spending a lot of money for it, then why am fighting all this depression? Why not go that way?' Thus, the biggest influence on the design of my houses was Robert Rauschenberg. My support system came from artists."’142

Ese sistema de apoyo, ese hallazgo, no fue otro que comprender que el arte funcionaba por desplazamientos que permitían cambios semánticos. Gehry entendió que esos desplazamientos tenían cabida en la arquitectura. A pesar de esa influencia él tenía muy claro dónde estaba su territorio de actuación. A la aseveración de Peter Arnell considerándole también un artista él responde: 


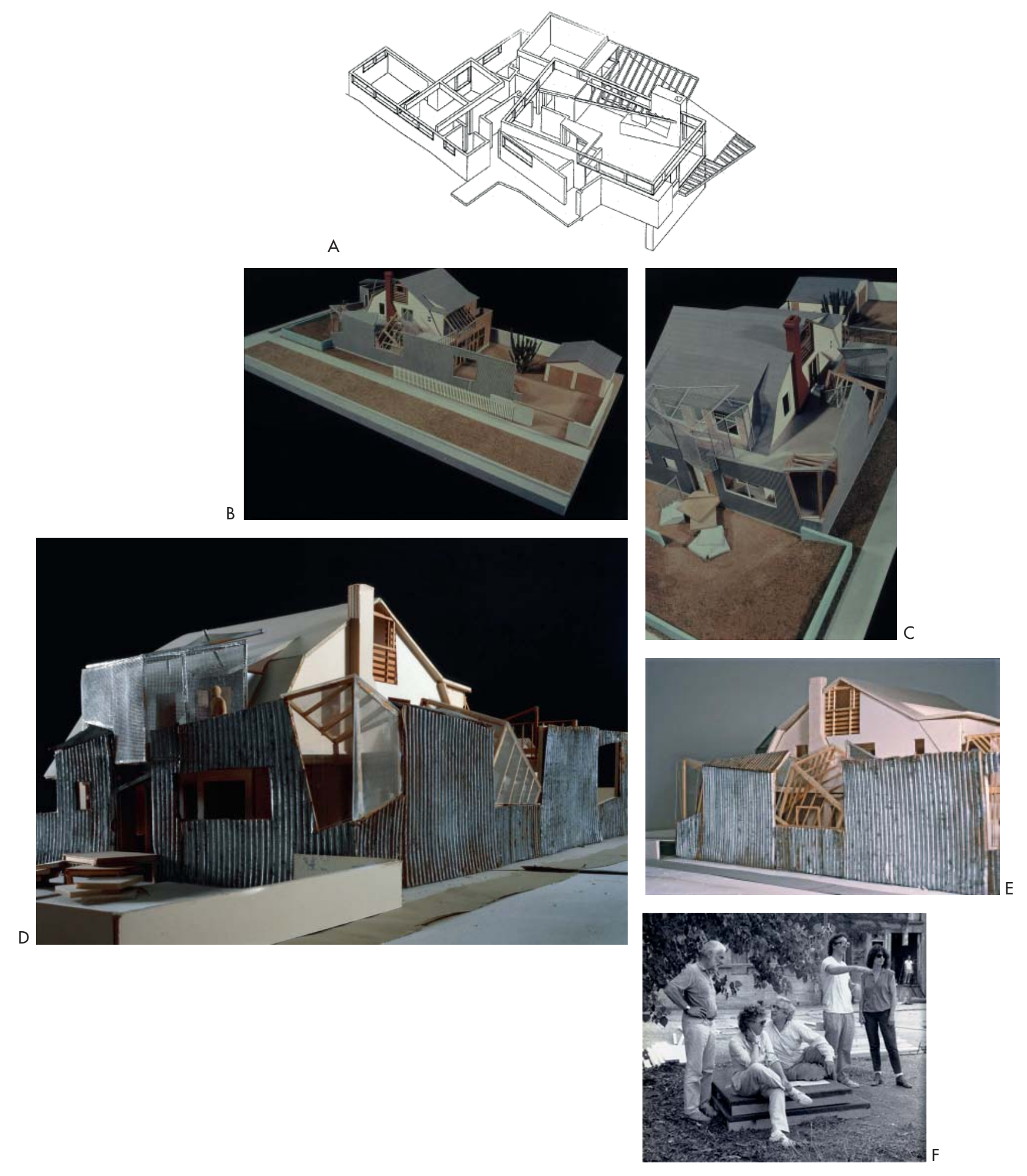


A. R. Schindler. Casa Armon, Los Ángeles, California,

(1946-1949). Axonometría.

B-E. Frank Gehry. Santa Monica (1978). Maqueta.

F. Anthony Caro, Sheila Girling, Frank Gehry,

Paul Lubowicki y Susan Nardulli trabajando en

Architectural Village, 1987.

\footnotetext{
143. Arnell, 1985: 14

144. Colomina, 2006: 126

145. Labarta sintetiza su posición: "El

estudio de la obra de Schindler no sólo nace de interés de recoger el eco del más olvidado de los pioneros de la arquitectura moderna sino que surge principalmente, desde la percepción de que su obra anticipa y coincide en determinados planteamientos que la vanguardia y la crítica contemporáneas han atribuido, con cierto aire de singular y exclusiva originalidad, al arquitecto canadiense-californiano Frank Gehry. El inicio de su trayectoria más conocida que culmina con su propia casa en Santa Mónica, está directamente relacionada con las actitudes, búsquedas y construcciones de Schindler, hasta el extremo de que no es posible, como la crítica especializada ha mantenido, sostener por más tiempo la mitificación de una supuesta vanguardia escondiendo las fuentes de donde surgió." Labarta, 2012: 71
}

"Soy un arquitecto. Salgo mucho con artistas y estoy muy cerca de ellos. Estoy muy involucrado con su trabajo. Pienso en lo que ha salido de allí...(pero) mi intención es hacer arquitectura." ${ }^{143}$

Tomemos la indicación del arquitecto californiano y profundicemos en el proyecto de la casa a través de nuestra disciplina. Como reconoce Colomina, muy rara vez se refieren Gehry o sus críticos a la influencia de otros arquitectos ${ }^{144}$ y cuando ocurre suelen ser lecturas críticas a través de analogías formales casi siempre para establecer un vínculo a través del aspecto del objeto. Sirva de ejemplo la comparación con la producción tardía de Rudolf Schindler que realiza Carlos Labarta para desmontar la presunta originalidad de Gehry. ${ }^{145}$ Pero, aunque vislumbremos un parecido razonable entre la Casa Armon de Schindler y la Casa de Santa Mónica, la comparación no deja de ser estéril para entender la obra de Gehry de aquella época. No es suficiente para explicar aquello que reconocemos en la obra como proceso innovador.

Es por eso que la mejor opción que se abre ante nosotros para seguir indagando es quizá recurrir a "la cocina" y a los que allí estuvieron. Este camino como vamos a ver es muy revelador y nos permitirá trazar una ascendencia diferente del proyecto, no como copia, sino como proceso y como evolución. Volvamos pues a los meses en los que Gehry estaba proyectando la casa.

Gehry hizo la mayor parte del proyecto por su cuenta, no quería involucrar a nadie hasta que no tuviera claro qué iba a hacer, lo que no ocurrió hasta pasado un tiempo. Gehry consiguió un joven colaborador que le ayudaría a desarrollar sus ideas. Lo había conocido meses antes en una visita a la Cooper Union con motivo de una conferencia y unas sesiones críticas a las que había sido invitado por John Hedjuk. Le gustó especialmente el trabajo de un estudiante de último año llamado Paul Lubowicki y le ofreció unas prácticas de seis meses en su estudio de California. Cuenta Lubowicki que cuando llegó a la oficina lo primero que encontró del proyecto fueron unos croquis en los que se podía ver una versión de la Ron Davis House, la casa estudio para un amigo pintor que había realizado en 1972, colocada delante de la vieja casa-rosa: 

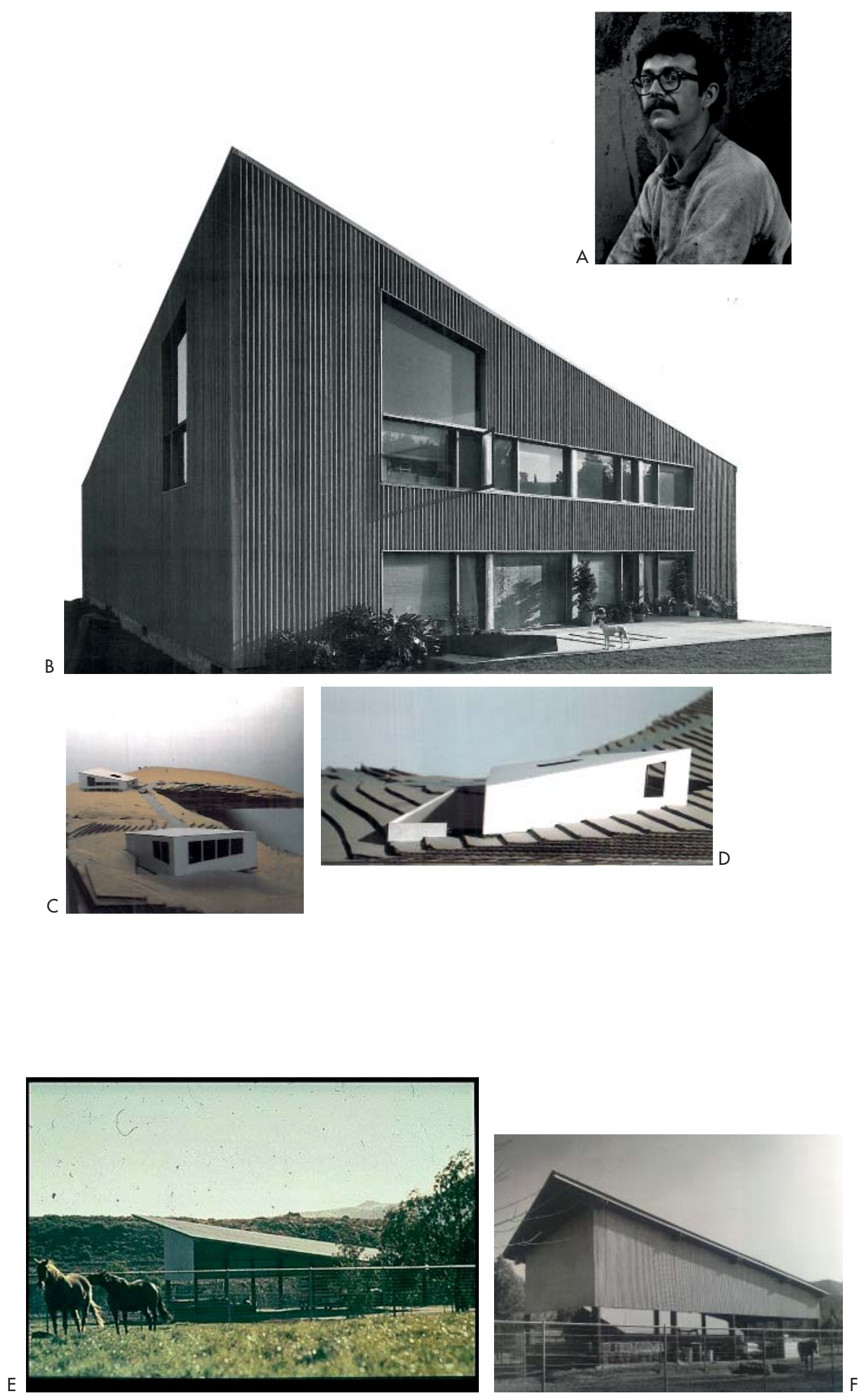
A. Ron Davis.

B. Frank Gehry. Ron Davis House (1972).

C-D. Frank Gehry. Ron Davis House (1972)

Maqueta.

E-F. Frank Gehry. Granja O'neill (1968)
"He [Gehry] was determined to push the house beyond the Ron Davis house" $" 146$

Lubowicki se puso a trabajar en el proyecto e hizo una primera maqueta con aquellos dibujos. Gehry empezó entonces a cortar y quitar partes de la maqueta. Como se dice, el resto es historia. Sin embargo, de esta anécdota lo que más nos interesa es precisamente el comentario de Lubowicki, ¿Qué quería decir llevar más allá el proyecto de la Ron Davis House?

Ron Davis era un pintor abstracto que pertenecía al grupo de artistas amigos de Gehry. Era de los pocos que había empezado a hacer algo de dinero con su obra y decidió invertirlo en comprar tres hectáreas de terreno de una granja para la cría de caballos en Malibu y hacer su casa estudio. Davis le ofreció a Gehry diseñar el proyecto con la idea de conseguir un espacio flexible para vivir y un estudio para pintar cuadros de gran formato. El proceso duró casi tres años en los que Gehry fue dando forma a las "fantasías" del artista, según diría el propio Davis. ${ }^{147}$ El proyecto acabó siendo una gran caja de metal corrugado, con planta trapezoidal y una gran cubierta inclinada cuya línea de máxima pendiente quedaba definida por esquinas opuestas lo que hacía que todas las paredes de la casa tuvieran diferente inclinación. La estructura se resolvió mediante el sistema constructivo de balloon frame dejando la madera expuesta al interior. La propuesta debía mucho en lo formal a un proyecto previo que había hecho Gehry para el almacén de paja de la granja O’Neill en 1968. Sin embargo quizá lo más singular de la casa no se encontraba en su volumetría sino en el espacio interior donde la gran carcasa metálica creaba un espacio urbano a partir de construcciones independientes que no llegaban al techo. Gehry dispuso las piezas de tal forma que la sensación era la de estar en una réplica abstracta de una aldea con calles, patios y casas que se conectan mediante pintorescas escaleras de madera.

En un primer momento al mirar el proyecto podríamos pensar que el gran contenedor alude al espacio del loft que los artistas de Nueva York habían empezado a colonizar por aquella época. Construir un gran volumen para ser habitado con la libertad de una vida desenfadada. Pero si miramos con detenimiento los dibujos y las plantas hay algo en esa interpretación que no encaja. El interior, aunque al principio estuviera pensado así, no es tan flexible ni esta liberado de construcción, por el contrario el espacio es mucho 

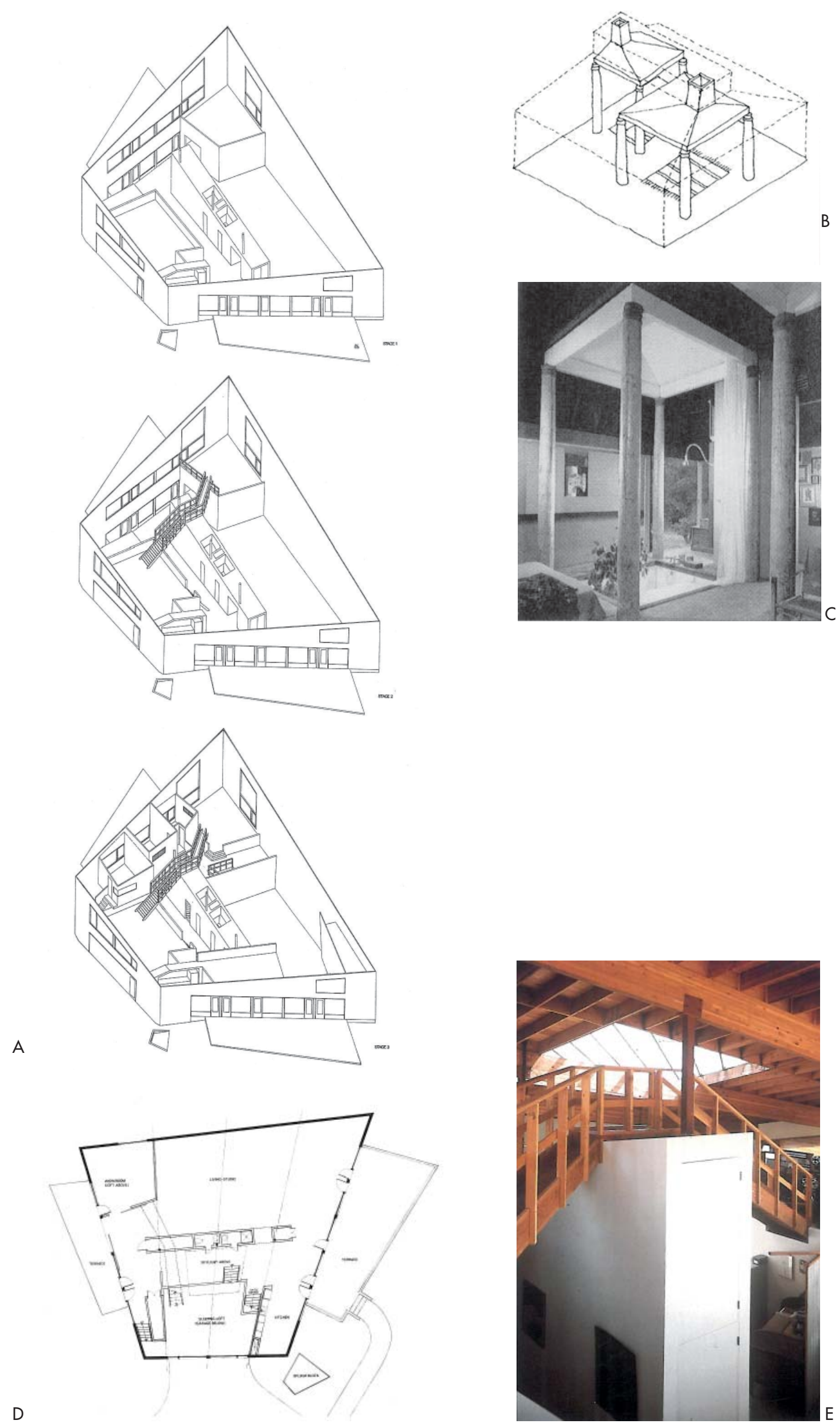
A. Frank Gehry. Ron Davis House (1972) Axonometrías.

B. Charles Moore. Charles Moore House (1962). Planta. Axonometría.

C. Charles Moore. Charles Moore House (1962) Planta. Aediculae.

D. Frank Gehry. Ron Davis House (1972). Planta. E. Frank Gehry. Ron Davis House (1972). Fotografía del interior.
148. Una interpretación de la casa desde esta perspectiva se puede consultar en el artículo de Rosemarie Haag Bletter "Las reconstrucciones espaciales de Frank Gehry". Cobb, 1988: 24-63 más juguetón y menos severo que el de los almacenes habitados por los artistas de la Costa Este. Es como si existiera la intención de recrear una escenográfica con interiores-interiores e interiores-exteriores o un amueblar con lo urbano. El proyecto es en realidad mucho más complejo. Frente a la habitual domesticidad de las habitaciones consecutivas o a la exaltación del vacío diáfano del loft, Gehry propone un camino más enrevesado: crea una gran contenedor deformado que se coloniza con una ciudad para ser habitada como una casa.

En la casa Davis volvemos a encontrarnos, igual que en la casa de Santa Mónica, con un proyecto fascinante en el que tiene lugar un evocador desplazamiento de estructuras espaciales y culturales desde territorios en principio ajenos al mundo de lo doméstico. Son proyectos que sin ninguna duda siguen lógicas genuinamente arquitectónicas y sin embargo resultan esquivas cuando intentamos entender su procedencia dentro de la obra de Gehry. Aunque, una vez más, hay múltiples lecturas de la casa Davis que sitúan la concepción del proyecto en esa genealogía de la invención formal vinculada con el arte, siguen siendo igual de estériles a la hora de explicar el proyecto como edificio y como proceso.

No es menos difícil encontrar, en el contexto arquitectónico académico de la época, referentes capaces de explicar los mecanismos que tienen lugar en esta obra de Gehry. Como otros jóvenes arquitectos, él se estaba intentando sacudir de encima la tradición moderna californiana de Neutra o Soriano y su arquitectura en ese sentido es especialmente explícita. Rosemarie Haag Bletter ${ }^{148}$ ha trazado una genealogía que lo emparenta con Louis Kahn, Richard Meier o Charles Moore por la forma en la que estos establecen relaciones de gradación desde el interior con el exterior. Quizá la más pertinente puede ser la que se establece con la residencia de Moore en Orinda de 1962. La casa un volumen simple contiene en el interior dos doseles similares a baldaquinos cuya finalidad es producir la sensación de intimidad en el ambiente de un espacio abierto. Sin embargo, la creación de esa "aediculae" interior es, como la definió el propio Moore, creado para conseguir una reverberación de la luz entre los planos de ambas cubiertas parece muy distante del interés de Gehry que, como podemos apreciar, no le dedica especial atención al diseño del lucernario. La casa Davis se resuelve sin articulaciones o alusiones históricas es, por el contrario, directa y cruda. 

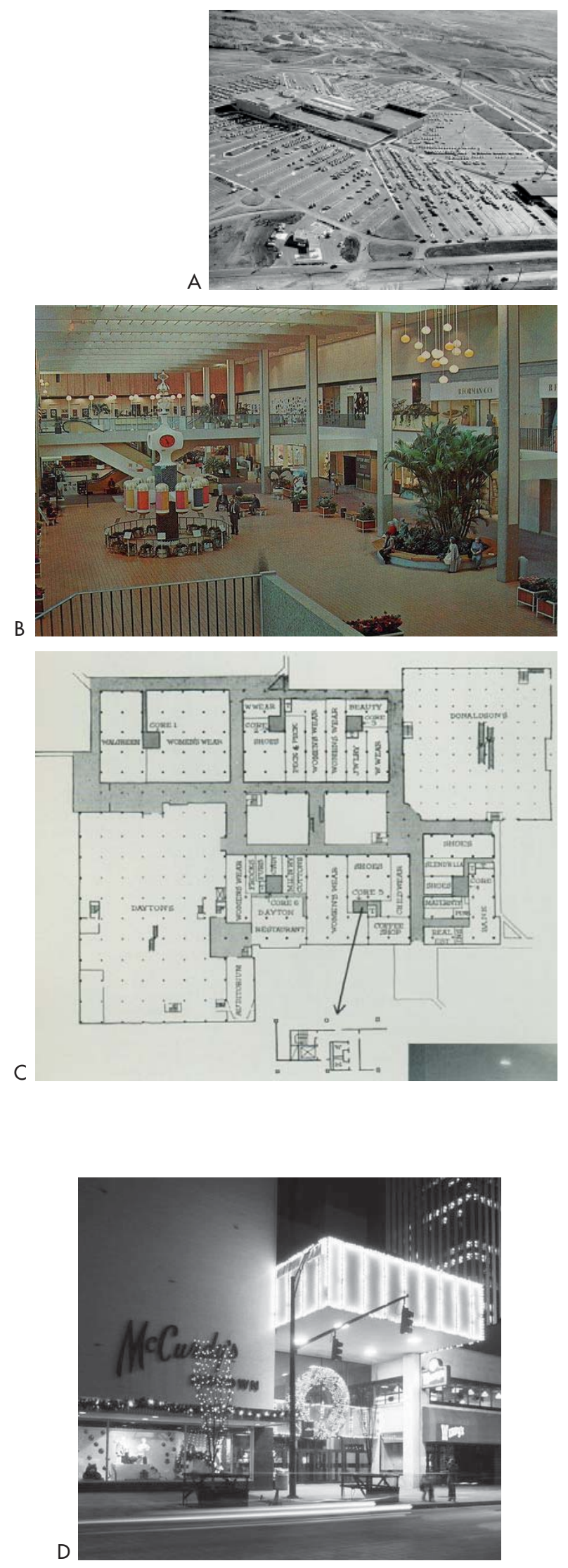
A. Victor Gruen. Southdale Center (1956). Imagen del exterior.

B. Victor Gruen. Southdale Center (1956). Interior C. Victor Gruen. Southdale Center (1956). Planta. D. Victor Gruen. Midtown Plaza, Roschester Nueva York (1962).

\footnotetext{
149. Moneo, 2004: 260

150. Recordemos que Gehry al inicio de su carrera estaba dirigida al urbanismo y que en Harvard en realidad entró a estudiar Planeamiento Urbano aunque fuera para él frustrante y lo acabara dejando.
}

Desde nuestro punto de vista es necesario trazar una genealogía mucho más simple y que no proviene de los archivos de la cultura, ya sean los del arte o los de la arquitectura sino establecer una con raíces en lo profano y menos intelectual. Lo que sostenemos es que en realidad lo que hace Gehry en la Casa Ron Davis es darle una vuelta de tuerca más a lo que había venido haciendo desde que terminara sus estudios de arquitectura en Los Ángeles y empezara su colaboración profesional con el arquitecto Víctor Gruen. Y tiene sentido que sea precisamente durante esos años de juventud donde se gesta todo porque suele coincidir con el momento en el que las ideas de los arquitectos se fijan con la persistencia de los tatuajes duraderos. Rafael Moneo se ha referido a esta etapa de la vida profesional de Gehry como "aquellos oscuros años de su formación," reivindicaremos como fuente de su arquitectura.

Gehry se graduó arquitecto en la Universidad del Sur de California en 1954 y comenzó a trabajar en el estudio de Victor Gruen en Los Ángeles. Tras un periodo en Harvard volvió otra vez en 1957 para colaborar durante cuatro años más. Por aquellas fechas Victor Gruen, austriaco emigrado, era una autoridad internacional en todo aquello que tuviera que ver con rehabilitación urbana ${ }^{150}$ y fue precisamente esto lo que atrajo a Gehry. Hoy, sin embargo, Gruen es recordado por ser el padre de los centros comerciales contemporáneos. La intención detrás del desarrollo esta tipología, hoy tan denostada, no era el de la especulación o el rendimiento económico sino, por el contrario, el de crear dispositivos densificadores del tejido urbano que ayudarán a crear una ciudad más amable para el peatón y menos dependiente del coche. Su idea inicial era que estos edificios se convirtieran en atractores con los que aumentar la densidad y así evitar la creciente e imparable dispersión de los suburbios. Gruen era un creyente de los espacios peatonales y pensaba que uno de los beneficios fundamentales de sus centros comerciales era que animarían a pasear a las personas de la misma manera que lo hacían las calles de los pueblos tradicionales en Europa. Gruen se equivocó diametralmente en sus previsiones: los centros comerciales se convirtieron en una pieza clave del modelo de ciudad dispersa centrada en el coche. Gruen renegó de su invención. Cualquiera que fuera el beneficio para la gente que andaba dentro del edificio no era comparable con el desastroso impacto que los centros comerciales tuvieron en el paisaje y en el ya de por si raquítico tejido peatonal de los pueblos americanos. 

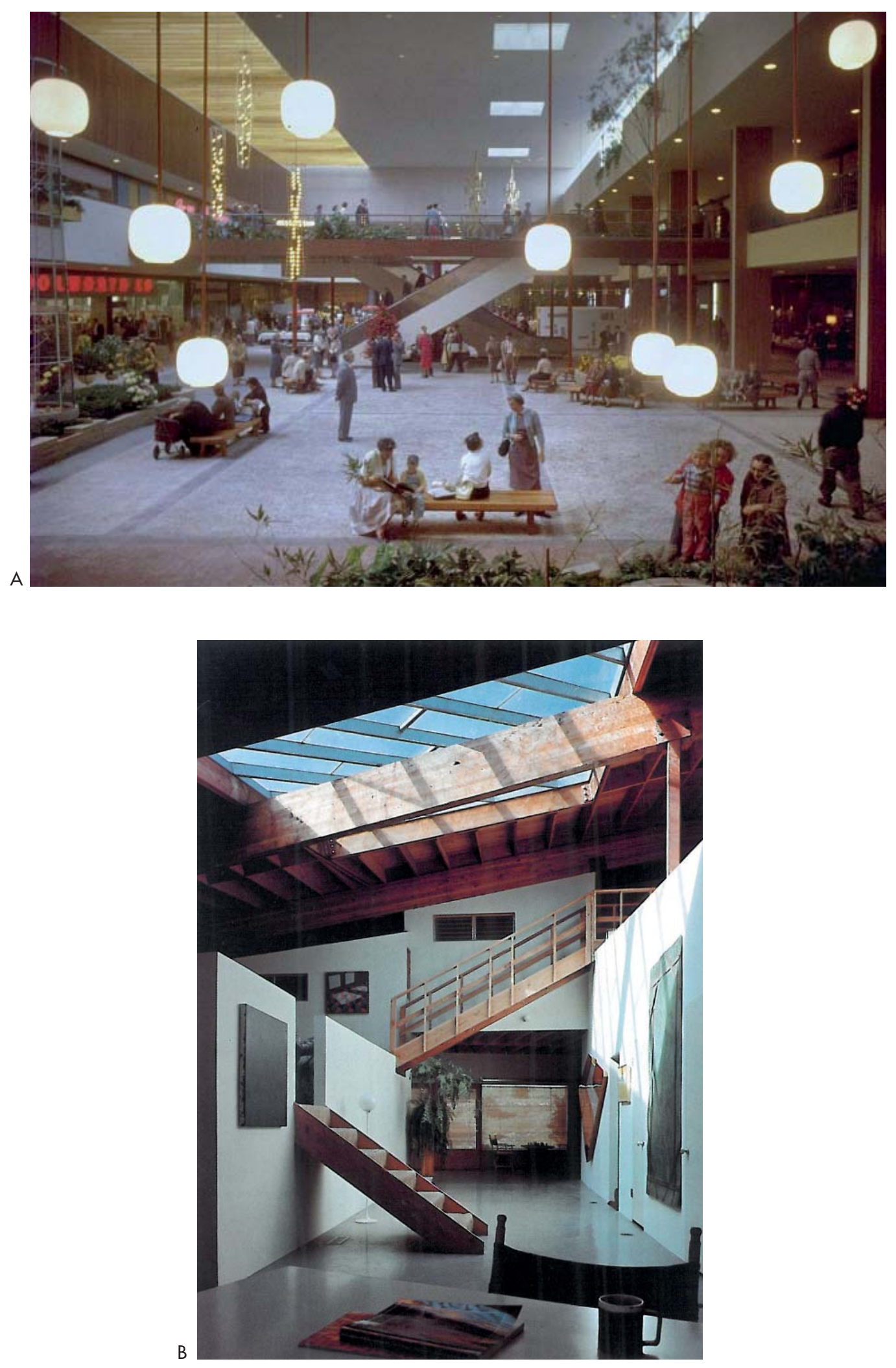
A. Victor Gruen. Southdale Center (1956). B. Frank Gehry. Ron Davis House (1972).
Cuando Gehry volvió al estudio en 1957 entró a trabajar directamente en el encargo más importante que en ese momento estaba haciendo la oficina: el proyecto del Midtown Plaza en Roschester, Nueva York. Consistía en un complejo de tiendas, oficinas y hotel que estaba pensado para sacar del declive y revivir el centro urbano de la ciudad. Fue terminado en 1962 y es considerado como el primer centro comercial cubierto en los Estados Unidos. Las ideas generadoras del proyecto ya se habían puesto a prueba un año antes en el Southdale Center, en las afueras de Minneapolis en 1956. Margaret Crawford describe así los mecanismo básicos utilizados:

"By enclosing the open spaces and controlling the temperature, Gruen created a completely introverted building type, which severed all perceptual connections with the mall's surroundings. Inside, the commercial potential of enormous spaces was realized in theatrical "sets" where "retail drama" could occur."

Midtown Plaza incluía dos grandes almacenes, cincuenta tiendas pequeñas, seis restaurantes y un gran parking subterráneo. En este proyecto Gruen tuvo libertad para diseñar el interior del edificio como si fuera una plaza urbana a imagen y semejanza de los centros europeos en los que la gente podría andar, comer y comprar sin necesidad de coger el coche. Era un simulacro de espacio público dentro de un gran espacio cerrado y controlado en el que se creaba la fantasía de un mundo exterior que reproducía la estructura de calles y plazas de una ciudad exclusivamente comercial.

Ahora quizá ya estemos en condiciones de realizar una afirmación que suene convincente y que trace una genealogía creíble para el proyecto. En la casa para Ron Davis, Ghery estaba utilizando la tipología del centro comercial con la que había experimentado mientras trabajaba para Gruen. Estaba poniendo a prueba la misma filosofía que intentaba aplicar a las tiendas. Quería construir un teatro, un espacio escenográfico similar al perseguido en el centro comercial. Un espacio urbano pintoresco con calles y patios; pasarelas y terrazas bajo las condiciones controladas de una enorme nave.

Si tomamos las imágenes de los centros comerciales en los que Gehry trabajó con Gruen, ya sea Southdale o Rochester, y las comparamos con el proyecto de la casa Davis encontramos múltiples similitudes a la hora de enfrentarse 


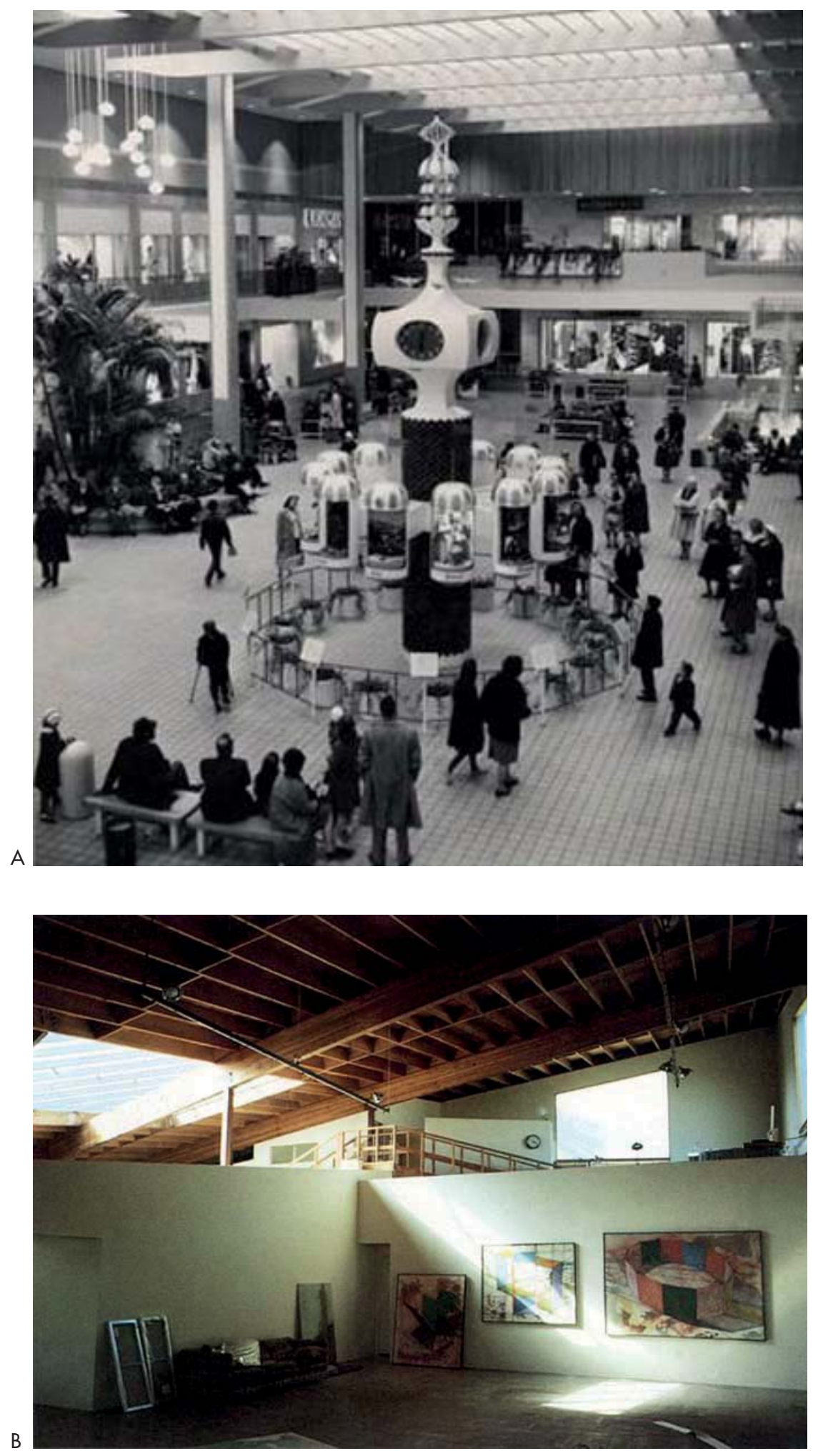


A. Victor Gruen. Southdale Center (1956) Fotografía del interior.

B. Frank Gehry. Ron Davis House (1972). Fotografía del interior.

\footnotetext{
152. Cobb, 1988: 26

153. En realidad tras la posguerra toda la industria que se dedicaba a la maquinaria de guerra tuvo que ser transformada para dar servicio a otros campos. Uno de ellos fue la construcción de perfiles de acero para la construcción. Sin embargo, en 1979, por la crisis energética de 1973 y el encarecimiento de las materias primas, la madera era un material mucho más económico.
}

al proyecto. Al contrario de lecturas críticas anteriormente revisadas, no nos fijaremos en las formas sino en las tácticas. Recorreremos las estrategias del centro comercial y veremos cómo estas se trasladaron en un inicio al diseño de la casa Davis y posteriormente a su propia casa.

El primer desplazamiento del centro comercial a la casa sería la idea de un gran volumen contendor capaz de crear un ambiente óptimo y controlado. Una Big Box en la más pura tradición americana. La idea detrás de esta pieza es que se puede crear la ilusión de un exterior si el espacio es suficientemente grande y se garantiza la suficiente iluminación natural. El contenedor se convierte así en un intermediario para crear una ficción que, al contrario de los contenedores temáticos que vendrían después, se comporta como una caja moderna y pragmática. El mecanismo en la casa Davis es idéntico, se crea un gran volumen que no pretende tener ningún tipo de identidad simbólica vinculada a lo doméstico. Gehry la define como "una cáscara estructuralmente vigorosa sin merma de la flexibilidad interior." ${ }^{152} \mathrm{La}$ estructura queda expuesta mostrando con crudeza su construcción, matizada por la calidez de la madera pero eludiendo de nuevo las retóricas domésticas. Es interesante ver también como frente a la tradición de las casas modernas californianas que fundamentalmente utilizaban el acero como material de construcción Gehry recurre al aún más barato sistema del balloon frame. ${ }^{153}$

Los mecanismos de relación con el exterior serán el segundo desplazamiento. El centro comercial selecciona solo una parte del mundo externo para recrear en su interior el suyo propio. La ubicación de las tiendas y el tamaño del contenedor hacen que la cubierta se convierta en el único intermediario directo con lo que está fuera. La visión horizontal se pierde de forma intencionada, desaparece la transparencia de las oficinas o de las casas modernas. Sin embargo los lucernarios aquí no se resuelven con articulaciones complejas como las que desarrollan los arquitectos canónicos de la época -pensemos en Louis Kahn-, sino que son mucho más pragmáticos y directos. En la casa Davis el lucernario de la cubierta sigue el mismo patrón: es un corte limpio de la cubierta que no altera la estructura. La luz no se conduce ni se entuba, directamente se desborda. Las ventanas altas tienen una función parecida, enfocan al cielo, y construyen un nuevo tipo de contacto. Constatamos ahora, y no solo para esta casa, que Gehry siempre tiende a fotografiar los espacios mirando hacia el techo, levantando el objetivo para capturar lo que pasa por allí arriba. 


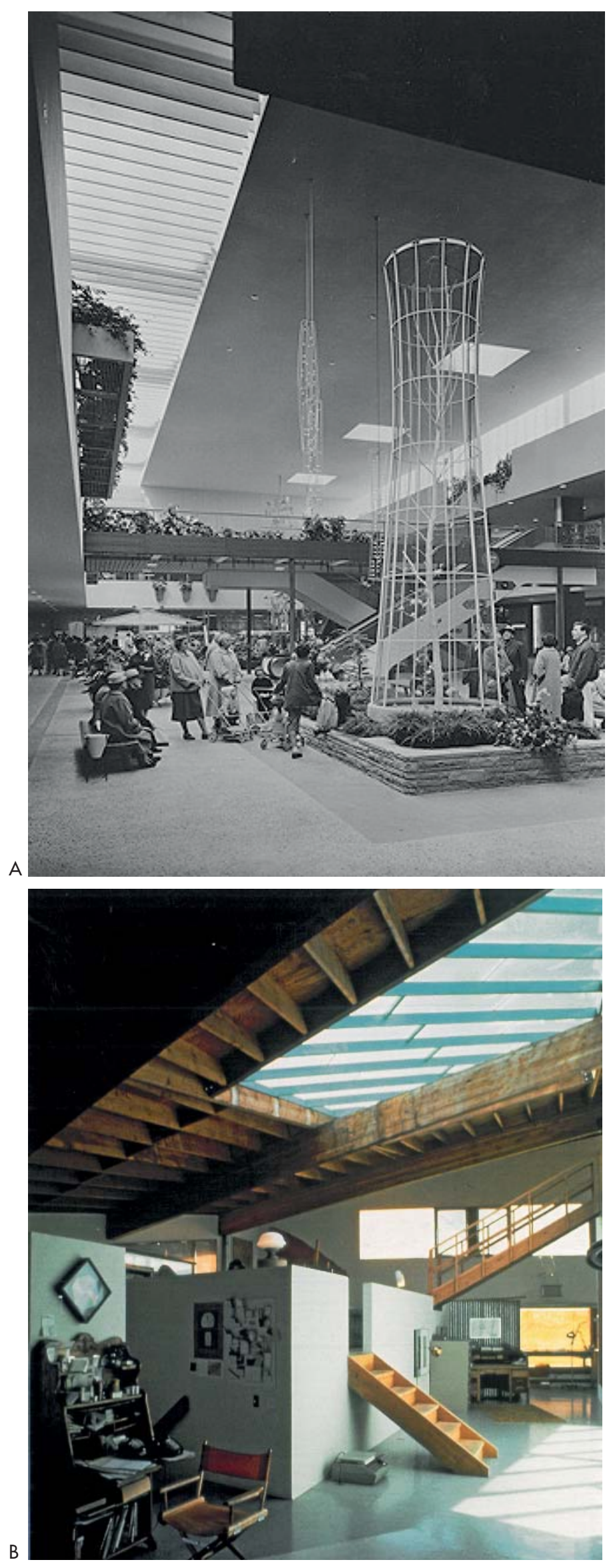


A. Victor Gruen. Southdale Center (1956) Fotografía del interior

B. Frank Gehry. Ron Davis House (1972). Fotografía del interior.
El último desplazamiento es la construcción de una urbanidad ficticia. Recrean la ilusión de un mundo exterior a pequeña escala en el que no falta de nada. Los centros comerciales recomponen un espacio público fantasmagórico y maquillado, en el que se eliminan las fricciones y solo dejan las ilusiones de una vida normalizada y feliz. El atrezzo compuesto por fuentes, plantas de interior, bancos y pequeñas construcciones arma una escenografía que permanece invariable día tras día, mes tras mes. Frente a lo imprevisible del espacio exterior este espacio es predecible, constante, higiénico y seguro. Los mecanismos arquitectónicos puestos en marcha son sencillos pero muy efectivos. Buscan multiplicar la conexión interior mediante un dispositivo espacial y visual que funciona en sección: el atrio. En este espacio central, alrededor del cual gira toda la actividad, se sobrexponen los elementos de comunicación y se genera una calle abalconada en la que todo queda a la vista. En la casa Davis, Gehry aprovecha los mismos mecanismos espaciales aprendidos en el mall. Se apropia de la alegoría de la ciudad y la proyecta dentro de la gran caja. Construye una réplica a escala de un espacio urbano condensado, con calles, patios, miradores y plazas. El efecto, lo sabe bien Gehry, se consigue evitando que los tabiques lleguen al techo, fragmentando e independizando los volúmenes hasta crear una calleatrio llena de acontecimientos. Utiliza los recursos aprendidos en el centro comercial: las visiones cruzadas, la escalera como protagonista y reclamo, los balcones, o los espacios diáfanos. Los fines subrepticios de lo comercial han desaparecido, ya no tienen sentido, pero sin embargo los dispositivos arquitectónicos que los sustentaban se muestran tan eficaces como en su antigua función.

El recorrido que hemos hecho nos ha permitido describir una genealogía del proceso del proyecto que entronca con la etapa de Gehry como joven empleado en el despacho de Victor Gruen, donde aprenderá los mecanismos de la arquitectura de ficción. Una arquitectura que promueve unos desajustes intencionados con la "realidad" para crear fantasías alternativas, fuera de escala y de contexto. Todo ello en complicidad con un habitante que es capaz de asumir la ficción y desea participar de ella.

Gehry siguió haciendo interiores de centros comerciales cuando abrió su propia oficina. A pesar de la mala fama y las críticas que estos fueron cosechando desde ámbitos académicos e intelectuales nunca renegó de ellos. 

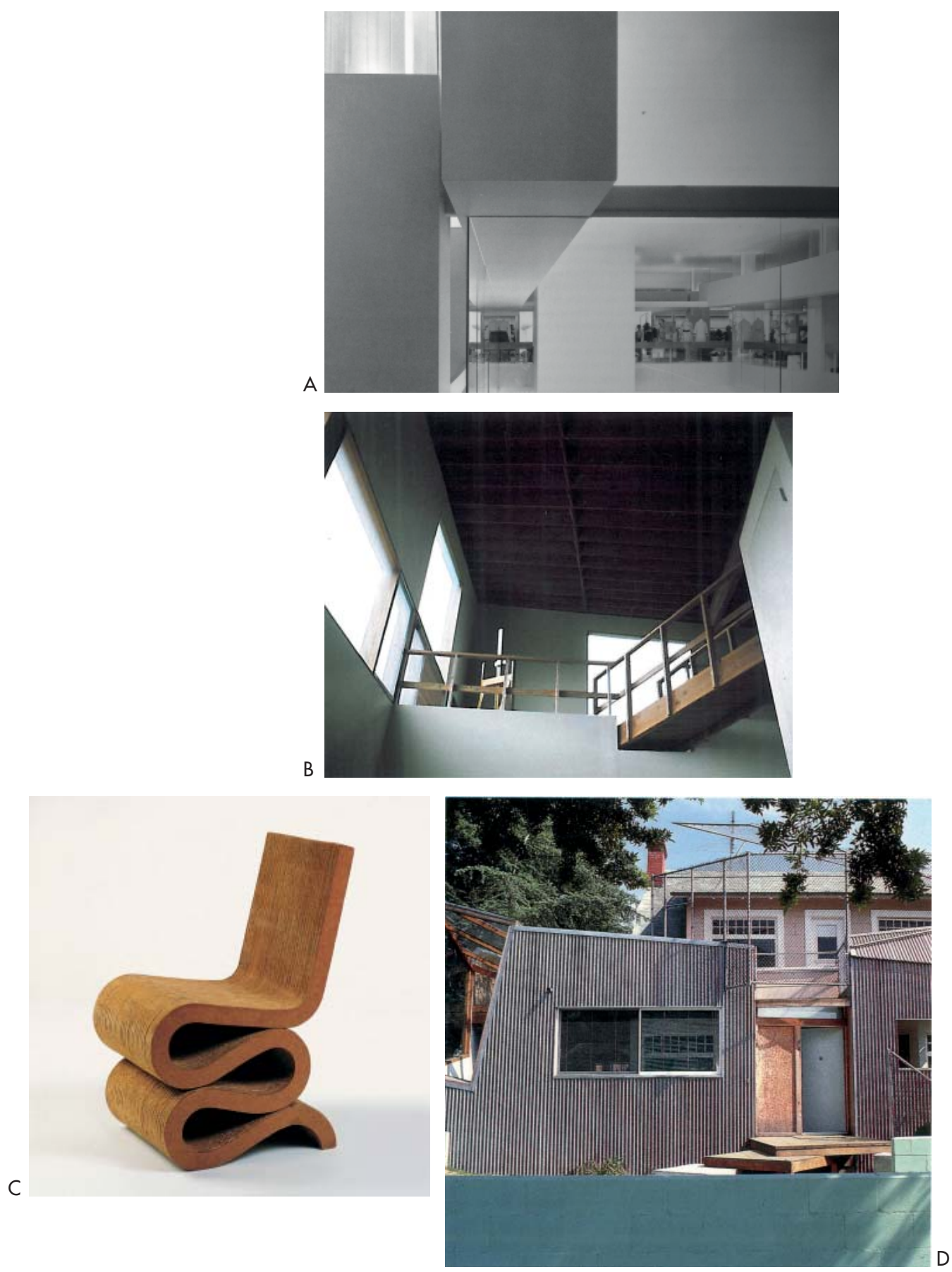
A. Frank Gehry. Locales comerciales para Joseph Magnin (1968).

B. Frank Gehry. Ron Davis House (1972). Fotografía del interior.

C. Frank Gehry. Wiggle Side Chair (1972).

D. Frank Gehry. Santa Monica (1978). Fotografía de la entrada norte.

\footnotetext{
154. Cobb, 1988: 67

155. Gehry desarrolló en 1972 una exitosa línea de mobiliario hecho con cartón corrugado encolado llamada Easy Edges.
}

Al contrario, defendía sus virtudes arquitectónicas. Al referirse a su trabajo para los locales comerciales de Joseph Magnin en 1968 lo hace patente:

"Durante el tiempo que trabajé en el despacho de Victor Gruen analicé reiteradamente el tema de los locales comerciales, puse frente a frente la cantidad destinada a materiales como la teca, el roble, los vidrios especiales o los accesorios de iluminación y el problema que suponía para una tienda responder correctamente a las demandas del mercado. Me molestaba el estatismo de esta tipología, el modo de servirse de los materiales, no su contenido arquitectónico. Cuando comprendí estos proyectos quise, primero, desembarazarme de los materiales caros, después hacer un escenario, un teatro dónde vender moda de vestir." 154

Lo único que le incomodaba de verdad era la ostentación con la que se construían, el recurso obligado a los materiales caros. Es ahí donde podemos fijar el origen de la utilización de materiales baratos encontrados en los catálogos más ordinarios de la construcción: malla de simple torsión, chapa ondulada, contrachapado o cartón. ${ }^{155}$

El resto de aspectos que se ponían en juego en la arquitectura de los centros comerciales como la teatralización, la ficción o el simulacro eran precisamente la forma en la que quería construir su arquitectura e iba a ser la herramienta con la que iba a generar la mayor parte de su trabajo posterior. De ahí que afirmemos que los desplazamientos proyectuales, del centro comercial al espacio doméstico, que Gehry realiza en la casa Davis se reproducirán, con limitaciones y por lo tanto alterados, en la totalidad-casa. 

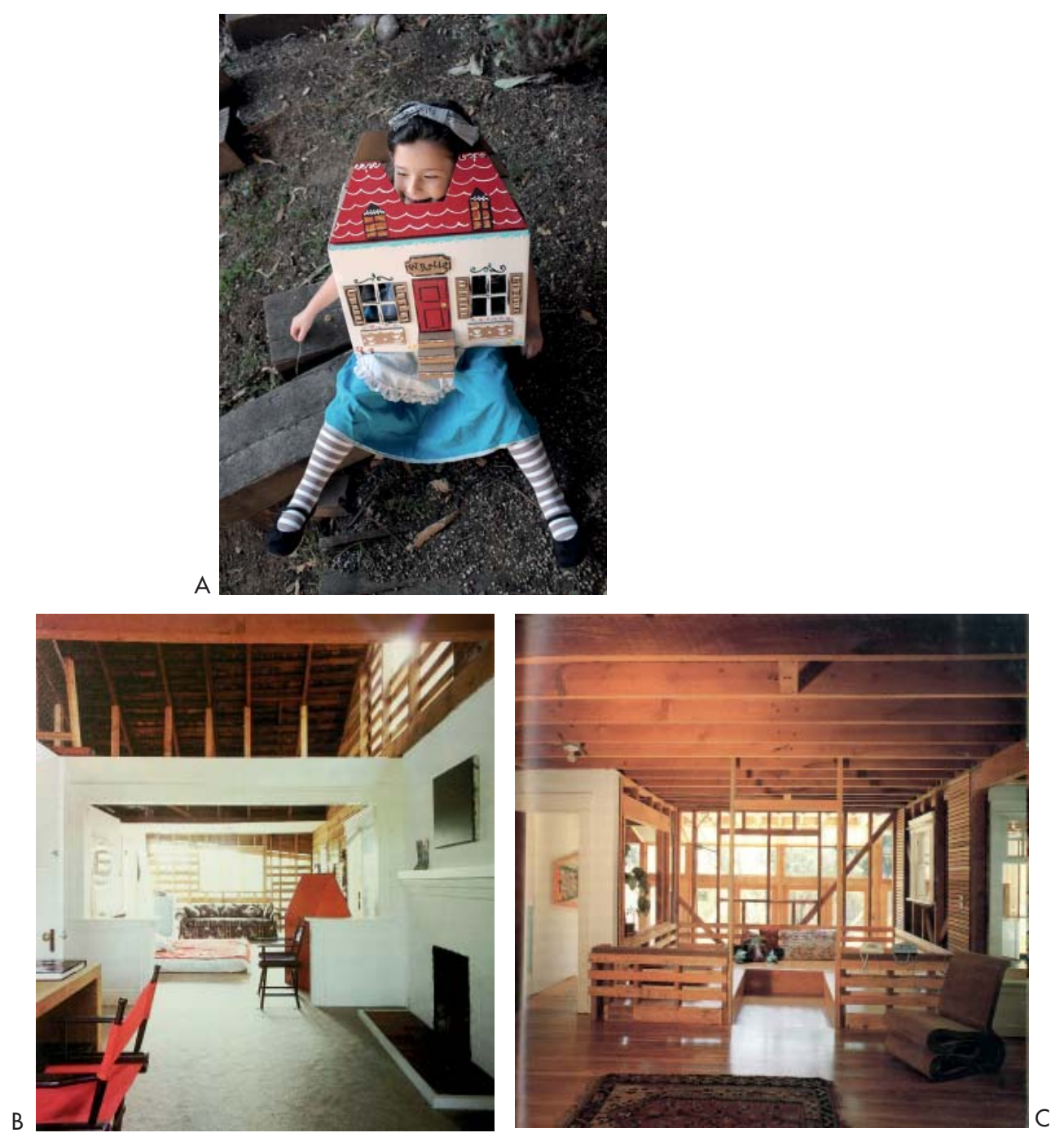
A. Disfraz de Alicia en el País de las Maravillas. B-C. Frank Gehry. Santa Monica House (1978). Fotografías del interior.

\subsection{LA TOTALIDAD-CASA COMO ESTADO DE ENCUENTRO}

Tras esta visita por la casa-rosa y la casa-Gehry y después de haber recolectado el instrumental crítico necesario en los capítulos anteriores, estamos en disposición de analizar la totalidad-casa. Vamos a explicar cómo, en esta agrupación heterogénea, se produce un estado de encuentro por el desplazamiento de imaginarios.

Como ya hemos visto, Gehry se impone como objetivo establecer una dualidad que se manifieste en lo simbólico y en lo físico. El reto es, por un lado, conservar la casa original ni interrumpiendo su lectura en ningún momento y, por otro, incorporar la teatralización y las propiedades de la Big Box que había explorado en la Casa Davis. Estos objetivos determinan toda una serie de ajustes que acabarán por dar forma al proyecto definitivo. Gehry en un artículo de la época lo explica así:

"The only important thing about my house is the neighbourhood it's in. The house isn't a significant example of period architecture. It was just a dumb little house with charm and I became interested in trying to make it more important. I became fascinated with creating a shell around it, one that allowed the old house to exist as an object, and, in a sense, defined the house by only showing parts. When you look through the new house you see featured parts of the old house in an edited fashion." ${ }^{156}$

Parece pues que la intención de Gehry, como narraba el ayudante en prácticas Paul Lubowicki, era superponer la casa Davis y la casa-rosa. El tamaño de la parcela y de la construcción existente hacía imposible semejante tarea. Ante la imposibilidad de la coexistencia de ambas tal cual eran, y en un giro irónico, Gehry decide cambiar las escalas, propone que la casa nueva no contenga la casa vieja sino que la casa vieja supere y atraviese la nueva carcasa miniaturizada. El resultado tiene algo de alucinación y de fantasía. Como en Alicia en el país de las maravillas, se produce un encogimiento del contenedor y, entonces, el cuerpo de la casa-rosa acaba desbordando sus límites. Sin embargo Gehry no renuncia al espacio híper conectado del centro comercial que estaba latente en la casa Davis y opta por realizar una operación que se 

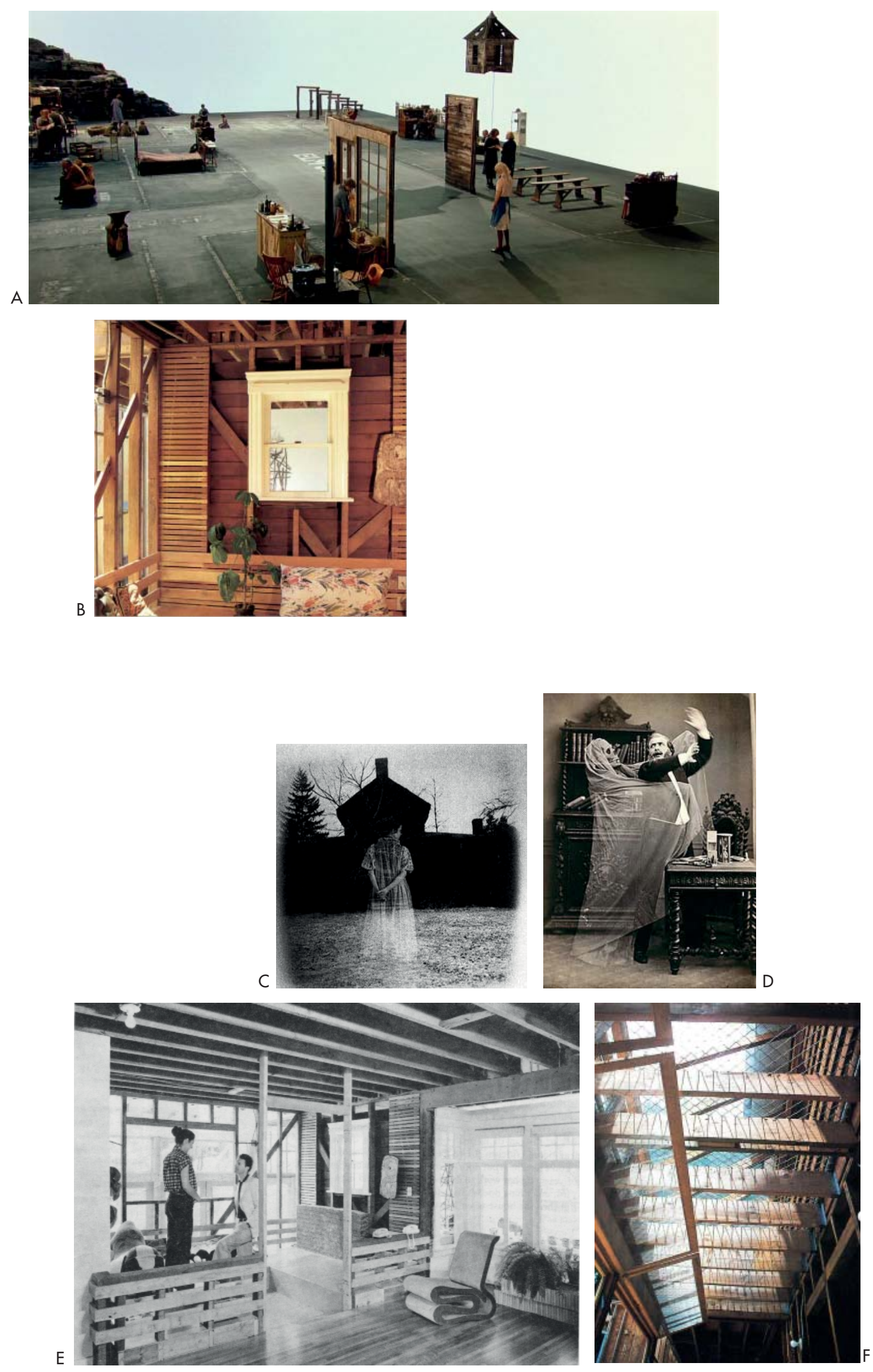
A. Fotograma de la película Dogville de Lars von Trier (2003)

B. Frank Gehry. Santa Monica House (1978) Fotografía de la ventana.

C-D. Fantasmas.

E-F. Frank Gehry. Santa Monica House (1978). Fotografías del interior.

\footnotetext{
157. Gehry, 1979a: 83

158. Forster, Gehry y Bechtler, 1999: 73

159. Lars Von Trier para su película Dogville

utiliza los mismos mecanismos para crear e decorado escenográfico en la que transcurre la película. Selecciona unos objetos que son capaces de hablar por el todo
}

tornará fundamental en el proyecto: recrear, en la intersección con la casarosa, el vacío virtual de la Big Box. "Conceptually the old house is a like one big room"157 dirá Gehry. Para conseguir la continuidad visual y física retira la materia que recubre las paredes sin perder la estructura portante y la organización original de los espacios. Gehry crea la ilusión del espacio continuo. Esa misma idea que sostenemos aquí es la que percibió Richard Serra cuando visitó la casa por vez primera:

"The first work of Frank that I saw was his house in Santa Monica in the seventies. It wasn't that he was reckless, rather he was fearless as he went about cutting and tearing his house apart, and simultaneously reconstructing the shattered remains with mundane industrial materials.-this was innovation. It immediately impelled me to reconsider the house as a container." ${ }^{158}$

La casa-rosa sufre una regresión material. Gehry pondrá a prueba el límite a partir del cual es admisible deshacer lo construido en el bungalow sin que pierda su identidad. El hallazgo de Gehry durante esta operación es entender que los componentes de la casa-rosa participan de una estratificación del significado. Es decir, el habitante no percibe por igual las diferentes capas de la casa porque las asociaciones semánticas que pueden realizar a partir de estas tienen alcances diferentes. ${ }^{159}$ En una suerte de sinécdoque espacial, Gehry delega en unos pocos objetos la labor de reconstruir el sentido del espacio original mientras que con otros llega hasta el límite físico, hasta su capacidad portante. Este hecho es fundamental en su ejercicio de teatralización. Por un lado respeta las ventanas en una especie de híper figuración y por otro plantea una abstracción radical al descarnar los tabiques originales hasta dejar vistos los montantes de madera.

El contraste hace saltar por los aires las convenciones de lo domestico y, al mismo tiempo, hace aún más evidente la existencia de una casa fantasma. Y decimos fantasma porque en la intersección de ambas casas, la superposición adquiere unas formas espectrales en las que la transparencia de una se superpone a la otra, no como una entidad física sólida sino como una forma desvaída, transparente. La casa antigua es atravesada virtualmente por el vacío del contenedor de la casa Davis en una superposición ambigua. No será esta la única forma de describir la totalidad-casa como un estado de encuentro 

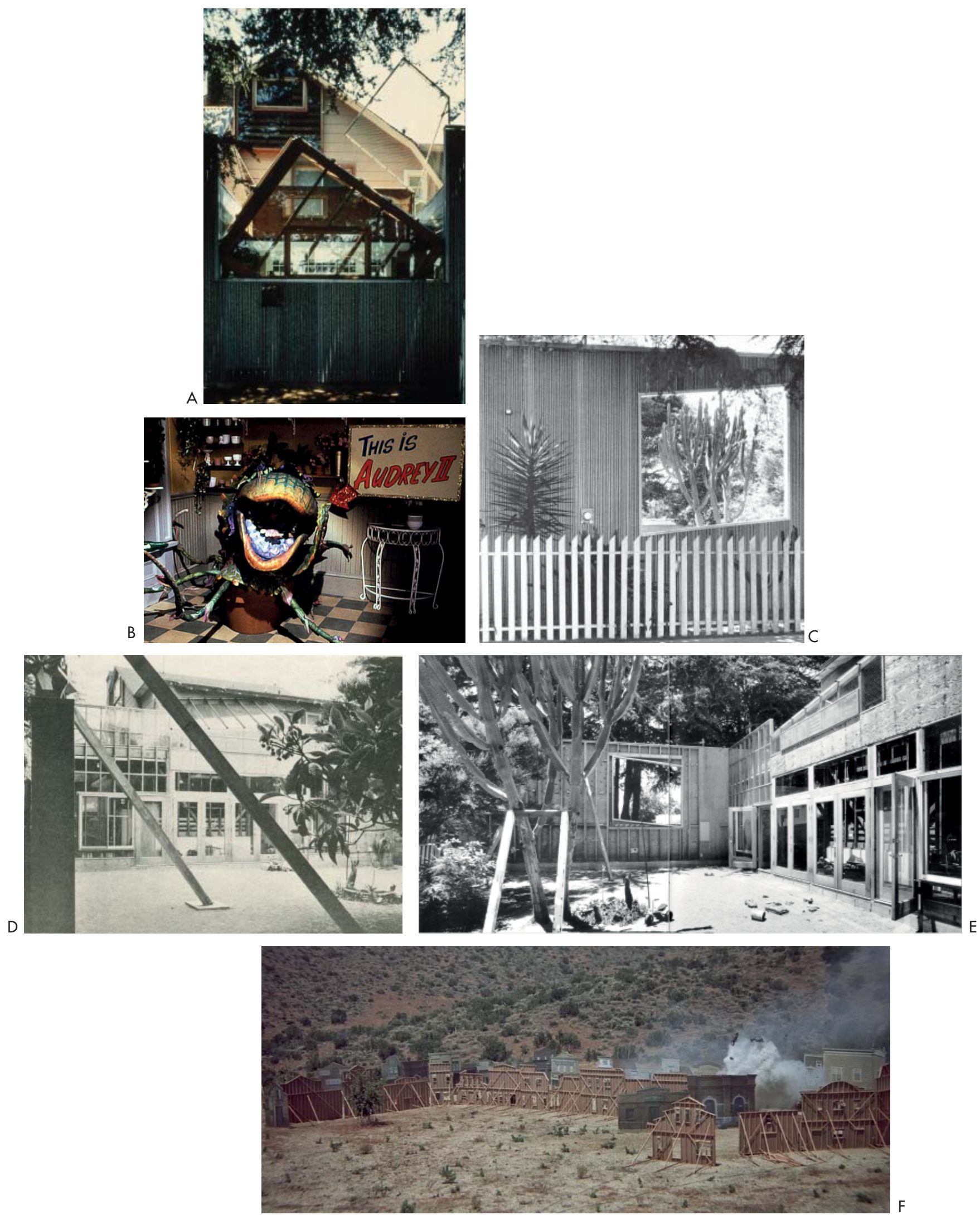
A. Frank Gehry. Santa Monica House (1978) Fotografía exterior.

B. Fotograma de la película americana The Little Shop of Horrors de Roger Corman (1986).

C-E Frank Gehry. Santa Monica House (1978) Fotografías del exterior.

F. Montaje de la película Blazing Saddles de Mel Brooks (1974).
160. Gehry, 1979b: 45
161. Ibíd.: 42
En nuestra visita a la casa Davis hemos visto como los mecanismos de relación con el exterior habían sido importados de la experiencia del mall. En la casa de Santa Mónica, estos mecanismos se confrontarán con los de la vivienda original. En la casa-rosa se mantienen las convencionales ventanas practicables a la altura de los ojos. Estas no solo sirven para seguir mirando a la calle sino que también se aprovechan en el interior para relacionar los antiguos espacios con los nuevos añadidos. Estas ventanas ficticias parecen formar parte de una dramatización espacial. Por el contrario la casa-Gehry utiliza los mecanismos del centro comercial, coloca las ventanas por encima de la altura de los ojos para asegurarse que la ficción se construye según las voluntades del arquitecto y no del contexto. Se limitan las distracciones y se potencia el interior como escenario. En la casa-Gehry todas las ventanas están altas, muy por encima del horizonte, salvan la visión del contexto construido y enfocan a las copas de los árboles y al cielo. Las ventanas de la adición evitan que desde el exterior se pueda fisgar lo que hacen sus moradores, en cambio, lo que sí permiten ver es la permanencia de la casarosa.

"From inside, all the windows are above eye level so they force your attention away from the street and give a sense of privacy, while maintaining a lot of the openness to the trees and the sky. Inside it's very light and airy and private, yet from the outside you can see into the house much more than into any of the neighbouring houses"160

En realidad todas estas decisiones ayudan a construir la ficción del decorado. Al conservar los exteriores, Gehry juega con los dobles sentidos y crea situaciones inesperadas en el interior. Este juego de confusiones no se da solo dentro de la casa sino que también involucra a los paseantes del vecindario. En el perímetro de la casa, la única ventana que queda a la altura de los ojos y a través de la cual esperamos ver por fin un interior, muestra la imagen de un curioso personaje, un cactus que nos mira.

"From the rear of the house, if you get far enough around, the exterior corrugated wall, looking toward the kitchen, reads like a stage-set- there are even diagonals holding it up."161 

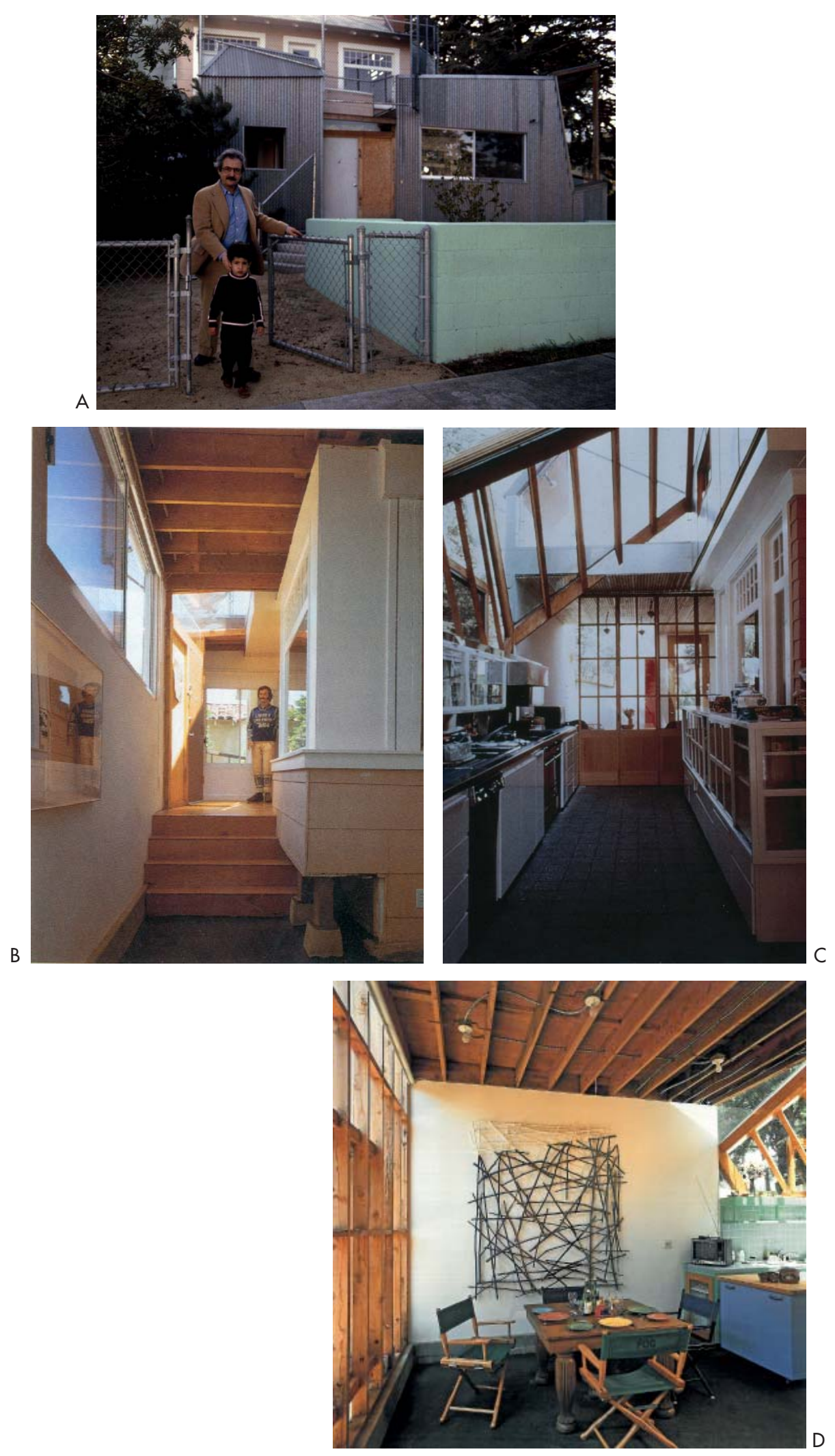
A. Frank Gehry. Santa Monica House (1978) Fotografía del exterior con Frank Gerhy y su hijo. B. Frank Gehry. Santa Monica House (1978). Vista del pasillo situado junto a la cocina. C-D. Frank Gehry. Santa Monica House (1978) Vista de la cocina.
Gehry reconoce que la casa se construye como un escenario e incluso lo hace explícito con humor al colocar soportes diagonales como los utilizados en los decorados del cine para sujetar la valla del jardín. A Gehry no le importa dar muestras en su construcción de esa fragilidad cinematográfica que la conecta con el mundo de lo efímero pero al mismo tiempo simbólico y fantástico. Gehry juega a crear ficciones e ironías solidificadas, ilusiones que intentan buscar acomodo y que, en la incapacidad de realizarse tal cual se habían pensado, acaban por encontrar formas adaptadas e inesperadas. Hablando sobre el resultado del lucernario sobre la cocina, Gehry recuerda:

"The idea grew from a fantasy in which these cube ghosts had been entrapped in the space when we built the new shell. Although, I wanted it to look like a cube, we couldn't actually make a cube out of it. The results is not exactly the illusion I had in mind, but it came out fairly well"162

Quizá es en la ambigüedad entre interior y el exterior donde se hace más explícita la condición de la totalidad-casa como estado de encuentro. Gehry interviene en lo construido y en sus significados para crear una lectura irónica del dentro y el fuera. Gehry sitúa el nuevo espacio a ras de calle, casi un metro por debajo del nivel de la casa original, y lo pavimenta con un asfalto negro para que no haya lugar a dudas del juego en el que nos quiere hacer participar. Esta elección colisiona con la decisión de ubicar allí programas genuinamente domésticos, como la cocina y el comedor. La confusión se hace aún mayor al mantener, como separación con el salón, la fachada original con sus ventanas, cornisas y tablones pintados de rosa. Así lo reconocía Phlip Johsnon que quedó fascinado con la casa cuando la visitó en 1979.

"It is the most thought provoking house in America, an amazing collection of bits and pieces. I like the window in the upstairs john and the sense of confusion in the dining room. I asked myself when I was there, "Am I in the dining room or the driveway?" It's an ordered confusion and a enormous house on a small lot."163

Gehry describía también como intencionada esa mezcla de ilusiones y confusión en dos artículos diferentes: 


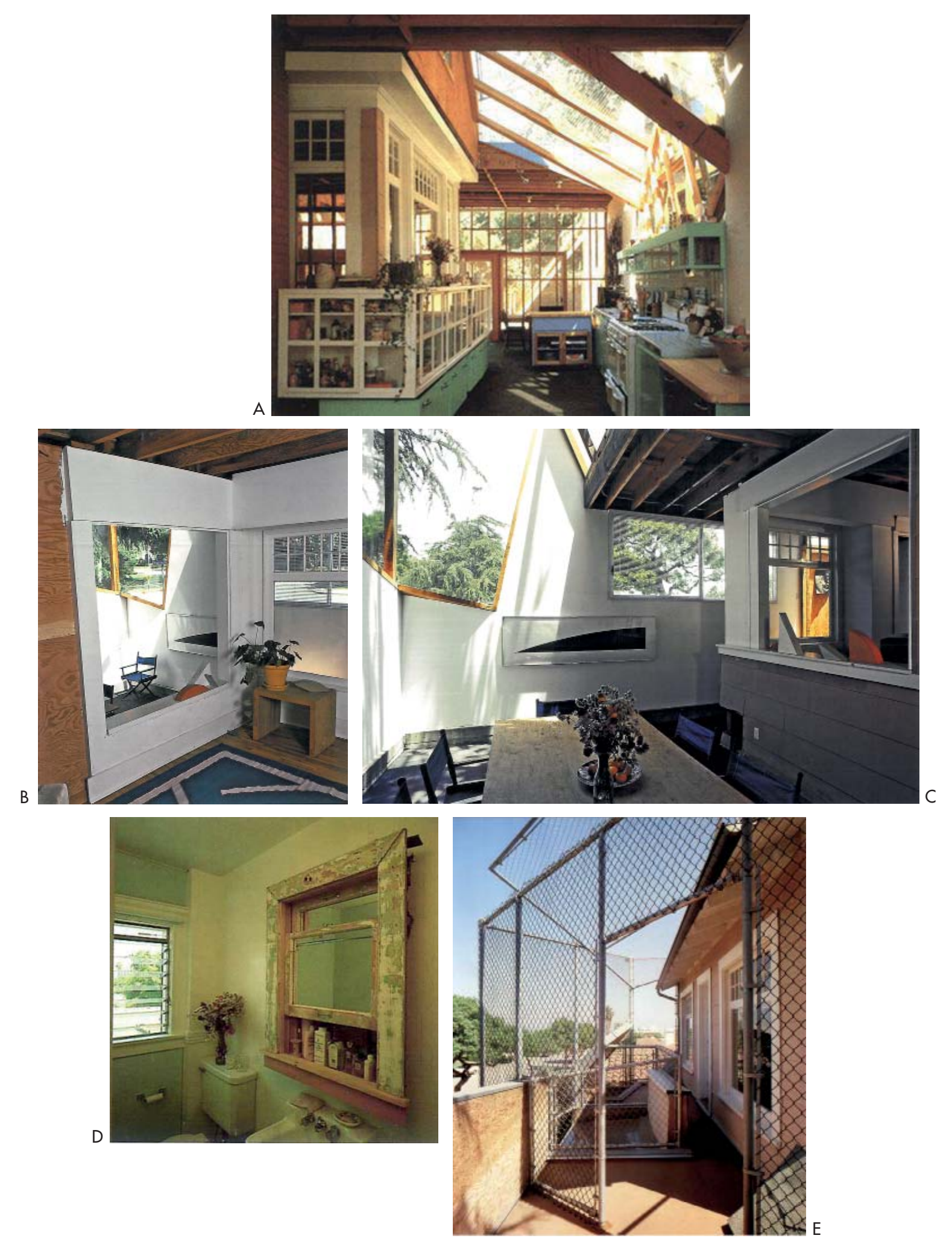


A. Frank Gehry. Santa Monica House (1978) Vista de la cocina.

B-C. Frank Gehry. Santa Monica House (1978) Vista de la cocina y del comedor.

D. Frank Gehry. Santa Monica House (1978) Fotografía del aseo.

E. Frank Gehry. Santa Monica House (1978) Fotografía del exterior.
164. Gehry, 1979b: 46
165. Frank Gehry: Architecture in Motion
Princeton: Films for the Humanities \& Sciences, 1996
"Sitting in the dining room and looking toward the window on the old house is quite surreal. The feeling is of being outside of the old house on the driveway- which is heightened by the asphalt paved floor. So there you are, sitting on a driveway, having dinner, looking back at the old house, and you're enclosed- yet the skylights reflect parts of the old house and reaffirm its presence in a very strong way, and the experience is surreal... when somebody walks through the old house and you see them through the window from the dining area or from the bay window in the kitchen, it's as if you're in a theater, and there are people on stage." 164

"if you go into my kitchen, and sit at the table, the sunlight passes overhead and leaves beautiful patterns from the trellises of the skylight on the walls, and it is very comforting, I think, and warm and friendly, etc. It's from that base then, you are sitting there and then you notice that you're in a room in which an existing old house is in the room with you, which is disconcerting, for a moment. I think you gotta put people in ease and then you can introduce the new information. Somehow." 165

El desconcierto es la expresión que mejor describe el efecto que estas simultaneidades generan en el visitante. La intervención desdibuja la idea de la casa, no solo de esta sino de todas las casas, de su genérico convencional $\mathrm{y}$, sin embargo, todos los desplazamientos se producen dentro del campo de lo doméstico. La casa-rosa se pone a prueba mediante pequeños desajustes intencionados que pretenden subvertir los significados de lo casero. Es una forma de trabajar con lo existente forzando los límites de la materia y del significado. Se opera mediante pequeñas acciones como trasladar la malla de simple torsión del lindero al tejado o como reutilizar para espejo del baño una de las ventanas originales. La casa-rosa ejerce de patrón o medida de lo convenido, constituye aquello que se considera "normal" en la construcción de lo doméstico. La casa-Gehry, por el contrario, realiza sus trucos de ilusión con la materia de la primera, la perturba para explorar tu límite. La intención no es violentar o desagradar, sino la de buscar la complicidad y la ironía de aquellos que contemplan la simultaneidad de la totalidad-casa. 

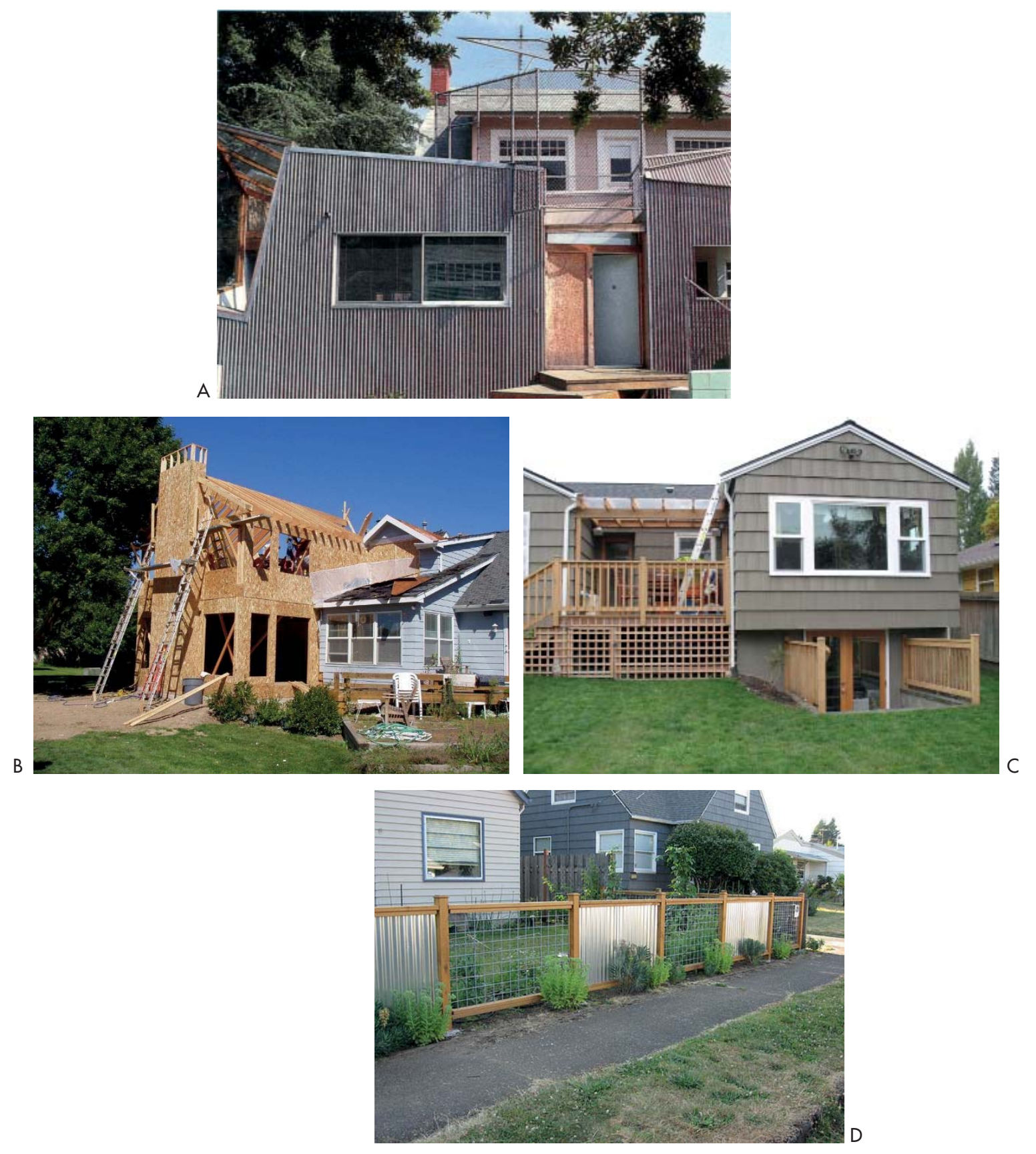


\subsection{RESISTENCIA A LOS \\ IMAGINARIOS EN LA CASA DE SANTA MÓNICA}

A. Frank Gehry. Santa Monica House (1978) Fotografía de la cocina.

B. Casa americana construida con Balloon Frame. Arquitecto anónimo.

C-D. Valla de casa americana. Arquitecto anónimo.
Algunas interpretaciones han asociado la casa de Santa Mónica con el bricolaje del hogar o el do-it-yourself. Craig Hodgetts se refería al proyecto en esos términos: "he is an uniniated, vernacular, honest, do-it-yourself style for the first time." ${ }^{160}$ Más allá del resultado final lo que se pone de relieve en la casa es una actitud que parece más próxima a los modos de operar desde lo ordinario que a las prácticas de la disciplina. Gehry adopta las maneras de los ciudadanos anónimos que mejoran el jardín o el porche de su casa en los tiempos libres después del trabajo. Pequeñas obras que a lo largo de una vida van haciendo que su casa sea más grande, más acogedora, en definitiva, que sea mejor. Como ha indicado Stewart Brand, la gente arregla sus casas por diversas razones pero una de las más comunes es para atenuar la frustración que sienten con el hogar. ${ }^{167}$ Este proceso se puede convertir en el trabajo de toda una vida. Una labor de adición constante. Es el tipo de transformación que hace que una misma casa en 20 años sea irreconocible a pesar de no haber sufrido nunca una transformación radical. Brand describe el proceso normal de una casa americana, aquello que moviliza las transformaciones:

"Homes are the domain of slowly shifting fantasies and rapidly shifting needs. The widowed parent moves in; the teenager moves out; finances require letting out a room (new door and outside stair); accumulating stuff needs more storage (or public storage frees up some home space); a home office or studio becomes essential. Meanwhile desires accumulate for a new deck, a hot dub, a modernized Kitchen, a luxurious bathroom, a walk-in closet, a hobby refuge in the garage, a kid refuge in the basement or attic, a whole new master bedroom." 168

Comparemos las expresiones de Brand y de Gehry, suenan muy similares:

"The kids needed bedrooms and stuff, and we had more money to spend. We built a pool. We fixed the roof. We fixed the skylights and the electrical system. A lot was done that unraveled that old house, and I lost it. The house has vestigial reminders of the old strength, 

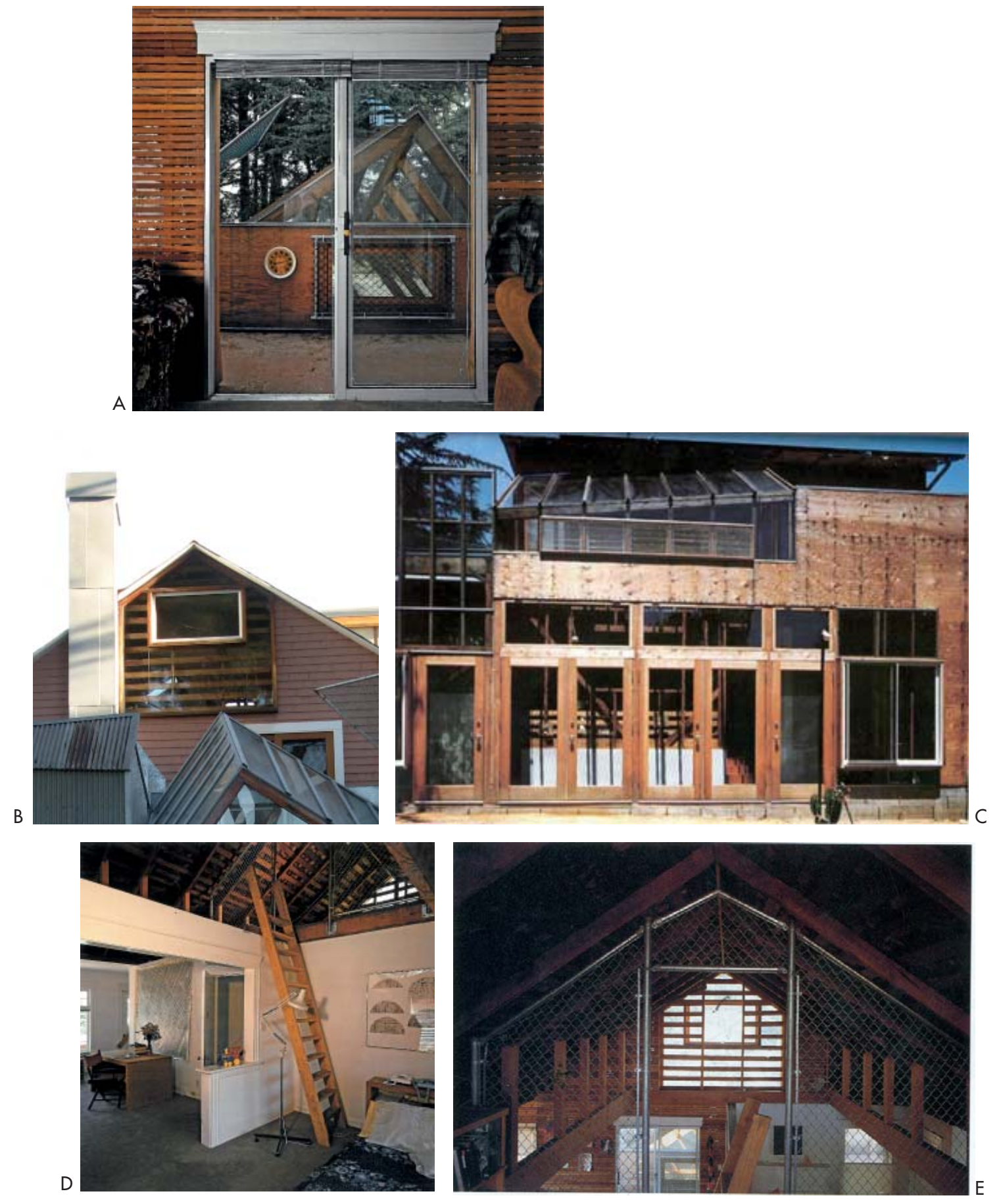
A. Frank Gehry. Santa Monica House (1978) Vista desde la ventana de la habitación principal hacia la cocina.

B-C. Frank Gehry. Santa Monica House (1978) Vistas exteriores.

D. Frank Gehry. Santa Monica House (1978). Vista interior de la habitación principal.

E. Frank Gehry. Santa Monica House (1978). Vista interior de la segunda planta de la habitación principal.

\footnotetext{
169. Isenberg, 2009: 68-69

170. Brand, $1994: 136$

171. |bíd.: 164

172. Como curiosidad cabe apuntar que los sistemas de reproducción casero de video llamado Betamax o VHS fueron lanzados en 1975 y 1976 respectivamente. En 1979, el mismo año en el que se construía la casa-Gehry, Betamax introdujo las funciones de búsqueda rápida llamada BetaScan y pausa con imagen. El cambio sustancial con respecto a la televisión es que este sistema permitía al espectador alterar la linealidad del visionado y cambiar el ritmo de la acción, ya fuera a hacia el futuro o el pasado.

173. Frampton, 1995: 216

174. También se podría leer esta confluencia como un estado de encuentro.
}

but it's not as good as house. It's not as good a piece of art, if you want to call it art, as it was on the first go-round. That's my opinion, although I'm pretty sure it would be shared by others who knew both. But I couldn't do anything about it. I had to lose it because I needed the room for the kids, and there was no way to preserve that original idea without contriving it in a second instance, and I didn't want to do that. So I just charged ahead and took it on the chin. Took one for the team."169

Gehry en cierto modo estaba siguiendo el patrón incremental de una casa ordinaria. "Vernacular houses assume the inevitability of later expansion and always seek the economical path, they are universally expert at growing by stages." ${ }^{170}$ Este crecimiento por fases está basado en la mejora de la habitabilidad y en la economía, no en la coherencia estilística. ${ }^{171}$ De ahí la habitual confusión que se suele apreciar en las construcciones ordinarias tras el pasar de los años. El proyecto de Gehry tiene algo de esos ensamblajes caóticos. Sin embargo, en la casa ese proceso parece condensado, como si el crecimiento habitual que se produce a lo largo de toda una vida se hubiera acelerado en un breve periodo de tiempo. La casa-Gehry es un fast forward, un avance rápido del proceso habitual de cambio de una casa ordinaria. La casa-rosa, por el contrario refleja un proceso inverso. Muestra una aceleración en la dirección opuesta, se empieza a deconstruir, pero no en el sentido arquitectónico que todos conocemos, sino en un mucho más literal. La construcción va perdiendo capas de pintura, yeso, entramados de madera hasta quedar en los huesos. Realmente la casa-rosa se está rebobinado. ${ }^{172}$ El crítico de arquitectura Kenneth Frampton apunta a este doble estado también:

$$
\begin{aligned}
& \text { “Usando literalmente 'la estrategia deconstructivista’ iniciada por el } \\
& \text { arquitecto Gordon Matta-Clark, Gehry crea una imagen ambigua. } \\
& \text { Siempre es difícil decir dónde está uno cuando habita el interior de la } \\
& \text { casa, si en una ruina abandonada o en un edificio en construcción." }{ }^{173}
\end{aligned}
$$

En su casa, Gehry está estimulando ambos procesos, el de construir y el de deconstruir, de forma simultánea ${ }^{174}$ para erradicar la frustración de lo edificado. Quiere transformar los significados de la casa no hacerlos desaparecer. Como ya hemos dicho anteriormente Gehry expresó en 


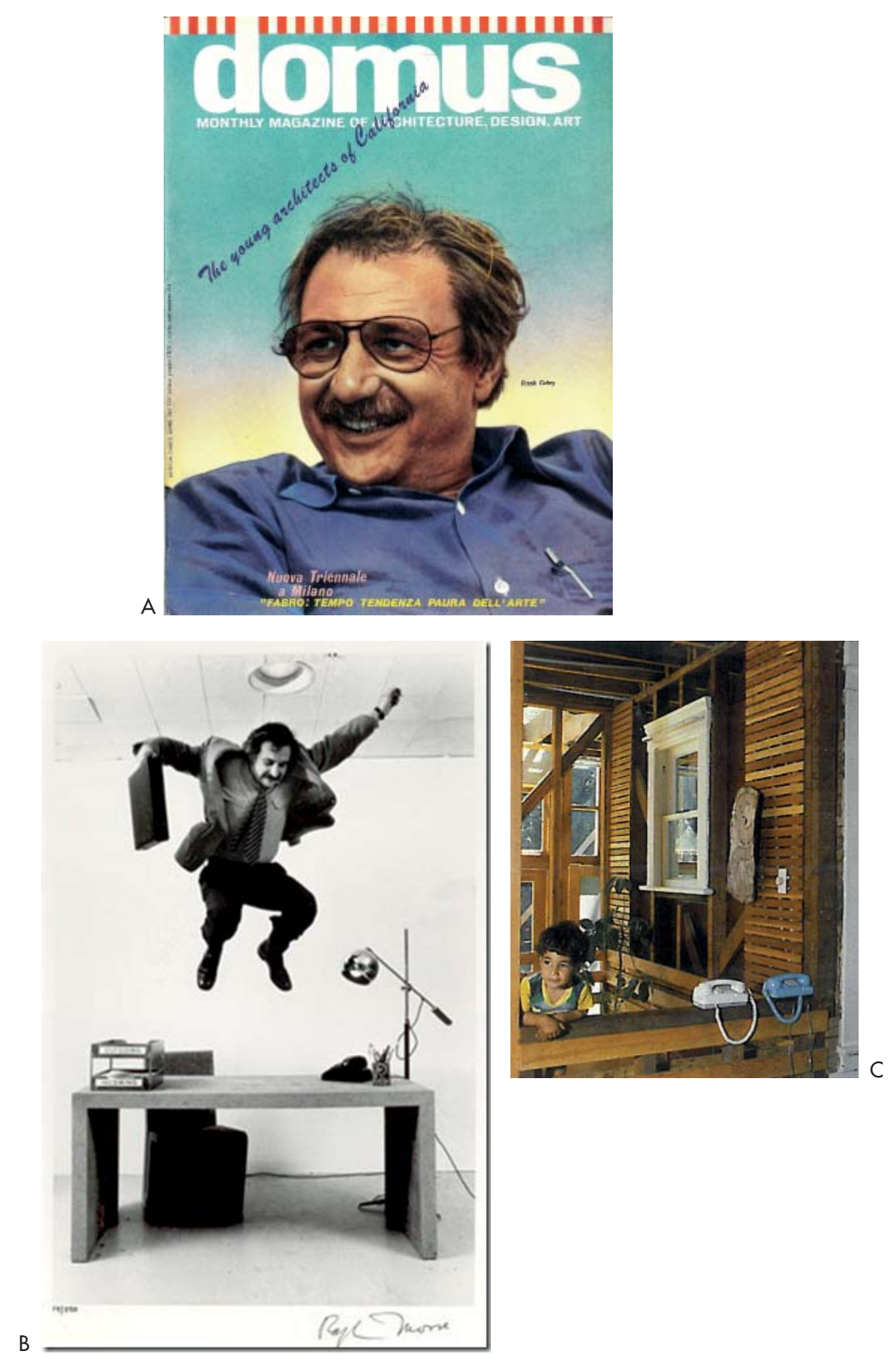


A. Portada de Domus, mothly magazine of architecture, design art. The young architects of california. Número 604, marzo de 1980. Caricatura de Frank Gehry.

B. Frank Gehry probando su mobilario. C. Frank Gehry. Santa Monica House (1978). Vista del interior, con Alejandro Gehry al frente.
175. en Cobb, 1986: 34

176. Este concepto alude a las ideas desarrolladas por Harvie Ferguson en su libro La pasión agotada: estilos de vida contemporáneos. Ferguson, 2010 reiteradas ocasiones su malestar con la anodina casa suburbana que su esposa compró. Le desagradaba tanto el barrio de clase media como la construcción, una "dinky little cutesy-pie house."175 Una casa vulgar en un barrio vulgar, lo opuesto a lo que su vida "artística" ansiaba. En cambio, para su mujer, la casa poseía un cierto encanto y sus pegas apuntaban sobre todo a un problema de tamaño y distribución. Gehry desdeñaba aquella edificación ordinaria y sin embargo quiso o se vio obligado a preservarla.

En realidad, la casa ponía de relieve el agotamiento habitual en las sociedades que tienen sus necesidades cubiertas. Responden a cambios que no parten de la miseria o la escasez sino de un distanciamiento hacia lo construido por su incapacidad para representarnos o satisfacernos. Habitualmente se tiende a pensar que las acciones de reparación o mantenimiento solo operan desde una dimensión funcional. Una ecuación que se plantea como problema y se resuelve como solución. En cambio, es difícil que se entiendan como modos de insuflar ilusión en lo edificado. La obsolescencia de la casarosa, más allá de los problemas de distribución, era esencialmente una obsolescencia del entusiasmo. Lo que Gehry mostraba con sus comentarios era un desapasionamiento por la materia construida, incapaz de colmar sus expectativas o de materializar sus deseos.

Desde un pensamiento puramente moderno, esta pasión agotada ${ }^{176}$ se habría resuelto mediante la ruptura con lo existente y la búsqueda de un nuevo origen libre del pasado, es decir, erradicando lo edificado para construir con ilusión algo nuevo. Sin embargo, el proyecto de la casa tomó otro camino. Es difícil saber si el origen estuvo en una decisión pragmática -no tenía dinero para tirarla y construir de cero-, o si realmente era un posicionamiento coherente con la posmodernidad de la década de los 70 .

Gehry necesitaba una herramienta que diera sentido a esta suerte de esquizofrenia: por un lado la necesidad de mantener la integridad de la casa, siguiendo la voluntad de su mujer y también de su limitada economía, y por otro, el deseo de establecer un proyecto capaz de doblegar la pobreza experiencial de la construcción. Visto desde esta perspectiva, el proyecto desarrollado por Gehry consiste, literalmente, en la coexistencia de ambas inquietudes. Gehry podría haber tomado la decisión de realizar su proyecto siguiendo el imaginario de la casa existente, como ya había hecho en 


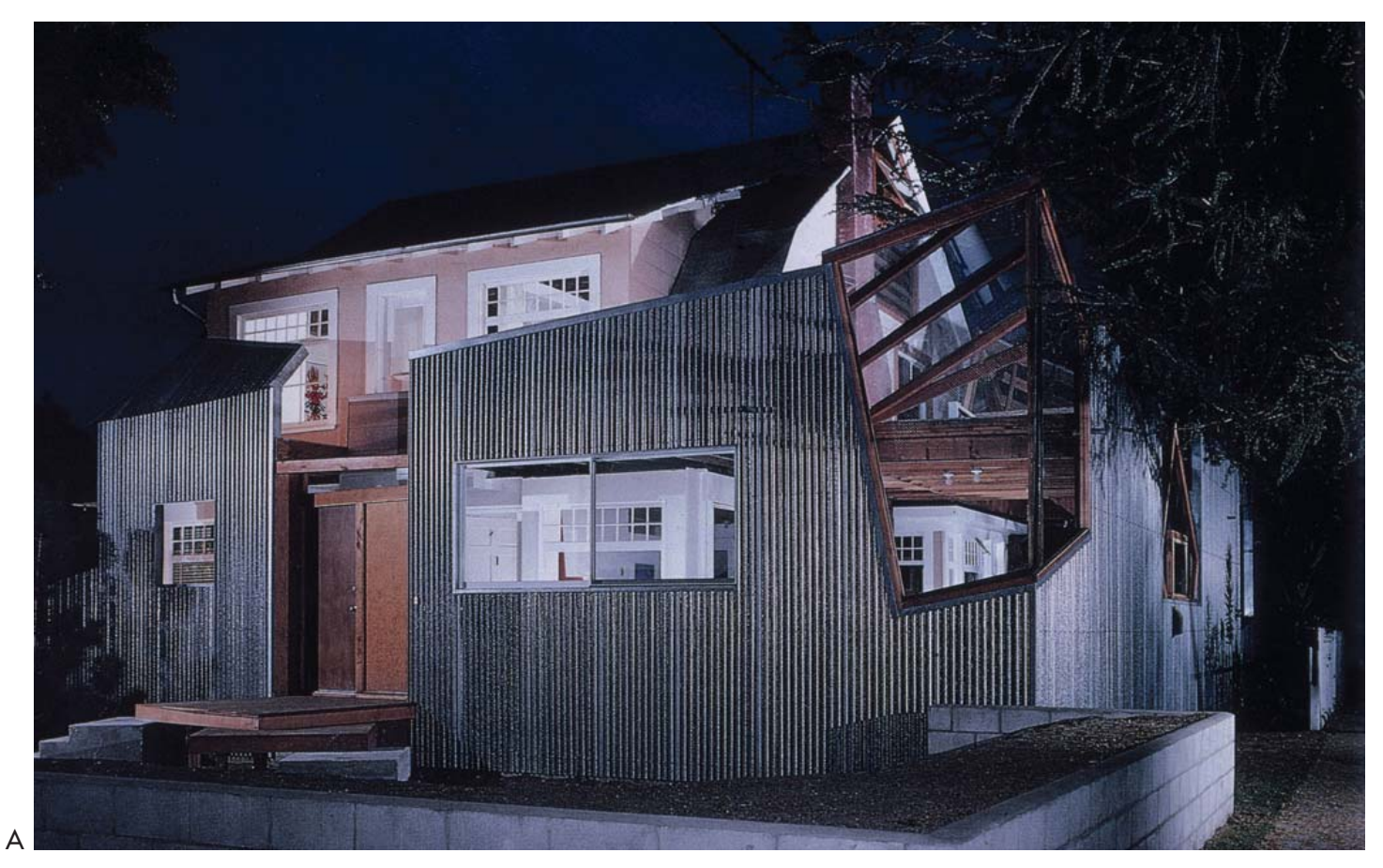


A. Frank Gehry. Santa Monica House (1978) Fotografía nocturna del exterior. también para referirse a la arquitectura de Gehry: "por ejemplo, Frank Gehry usó algo parecido a una técnica de 'montaje' en varios de sus proyectos de finales de los años 1970 en Los Ángeles y sus alrededores." Curtis, 2006: 605 el proyecto para el apartamento de St. Ives Drive, aunque, seguramente, ese camino hubiera sido estéril para resarcir la aparente mediocridad que asediaba a la casa. Sin embargo, al optar por traer el los imaginarios de la ficción del centro comercial revisitados en la casa Davis, el planteamiento cambia por completo. El resultado es el de un cuerpo arquitectónico en el que cohabitan dos sensibilidades; dos mundos; dos casas. Es un ejercicio de montaje ${ }^{177}$, una agrupación heterogénea.

El proyecto de la casa de Santa Mónica se convierte en una suma de decisiones en torno al dilema de la permanencia y el cambio. En todas las actuaciones derivadas de ese dilema entra en juego la Teoría de la resistencia a los imaginarios. Por un lado, tenemos el apego asociado a la materia: Berta se identifica con la casa que, sin la ayuda de su ocupado marido, se había encargado de elegir. Los afectos de Berta impregnan el antiguo bungalow y de alguna forma lo previenen de la destrucción. También lo simbólico emerge y determina lo que caracteriza y constituye la casa, aquello que si se perdiera haría que esta dejara de ser. Por otro lado, la casa cuenta con su propia defensa, los componentes que la constituyen establecen su oposición estratificada según la jerarquía marcada por las técnicas constructivas y los materiales utilizados. Por separado determinan un tipo de agencia de la materia que tiene que ver con la volatilidad pero también con la permanencia.

El trabajo de Gehry desafía la tenacidad de la casa-rosa desde una doble perspectiva. Primero, desde su resistencia material, preguntándose de dónde y cuánto puede quitar, y segundo, cuestionando las convenciones asumidas en torno a la construcción de lo doméstico, qué es una valla, un muro, una ventana, etc.; y por lo tanto, redefiniendo la semántica de los objetos que constituyen la casa. No se debe confundir esta deriva con un desafío a los modos de vida. Desde el punto de vista de los rituales hogareños, la casa es tan convencional como lo era antes de la remodelación. A Gehry lo que le interesa es construir una escenografía que movilice el extrañamiento y renueve el interés de sus habitantes. En definitiva, crear una ficción tan precaria e inestable como emocionante. 

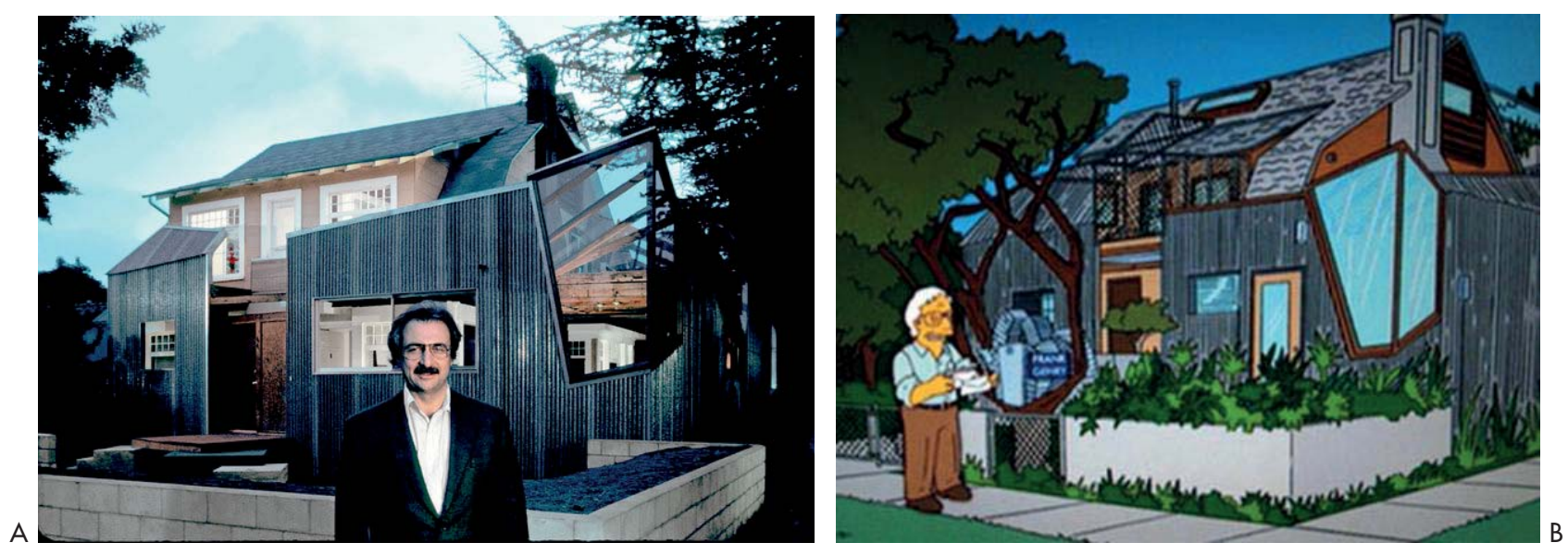


\subsection{CARTOGRAFIA DE LA INNOVACIÓN. GUÍA DE DESPLAZAMIENTOS}

\begin{abstract}
A. Frank Gehry. Santa Monica House (1978). Fotografía del arquitecto junto a la casa antes de las ampliaciones de malla.

B. The Seven-Beer Snitch, Ilamado El soplón vive arriba en España y El informante en Hispanoamérica, es un episodio perteneciente a la decimosexta temporada de la serie animada The Simpsons, emitido originalmente el 3 de abril de 2005. El episodio fue escrito por Bill Odenkirk y dirigido por Matthew Nastuk. Frank Gehry fue la estrella invitada, interpretándose a sí mismo.
\end{abstract}

La casa de Santa Mónica es hoy un clásico de la arquitectura del siglo XX, forma parte de la historia de la arquitectura contemporánea y es reconocida como una de las obras más importantes del último cuarto de siglo. No obstante, hubiera sido una apuesta arriesgada ubicarla en tan alta posición cuando empezó a ser proyectada. A priori, el proyecto tenía poco recorrido y muchos condicionantes en su contra: era apenas una ampliación en el jardín delantero de una casa anónima y sin gracia, una intervención precaria en lo económico y con un programa convencional. Tampoco Gehry tenía el reconocimiento que tiene hoy en día ni contaba con el aval del prestigio. El proyecto, sin embargo, desencadeno poderosos cambios. No solo para la trayectoria profesional de Gehry sino también para la forma en la que la casa-rosa afrontaría sus viajes en el tiempo. No nos referimos solo a los cambios físicos sino también a cambios inmateriales. La incertidumbre sobre el futuro del bungalow holandés, inherente a su condición de objeto ordinario, se despejó; la operación de Gehry le concedió una trascendencia que tenía vetada por su origen profano. La casa-rosa pasó a formar parte de una construcción singular, de una obra de arte. Rafael Moneo, refiriéndose a la obra de Gehry, hace una interpretación parecida:

\footnotetext{
"Paradójicamente, la obra de Gehry se defenderá de su manifiesta debilidad por el valor de que la dota el ser considerada singular, única, obra de arte. En efecto, la obra de Gehry, sobre todo al comienzo de su carrera, es extraordinariamente frágil. Débil en los términos más literales de la palabra. Pero aquel objeto frágil, consecuente con la condición efímera y cambiante de Los Ángeles, tan solo perdurará si se reconoce como obra de arte: en Los Ángeles un edificio merece que lo conservemos tan solo si es considerado una obra de arte."178
}

Aunque el comentario es general para las primeras obras de Gehry, Moneo hace explícito dos de las condiciones fundamentales que entran en juego en la casa de Santa Mónica. El primero es entender la casa como obra de arte y por lo tanto como un objeto significado, el segundo es señalar como su condición de obra de arte estimula su preservación. Estos dos 

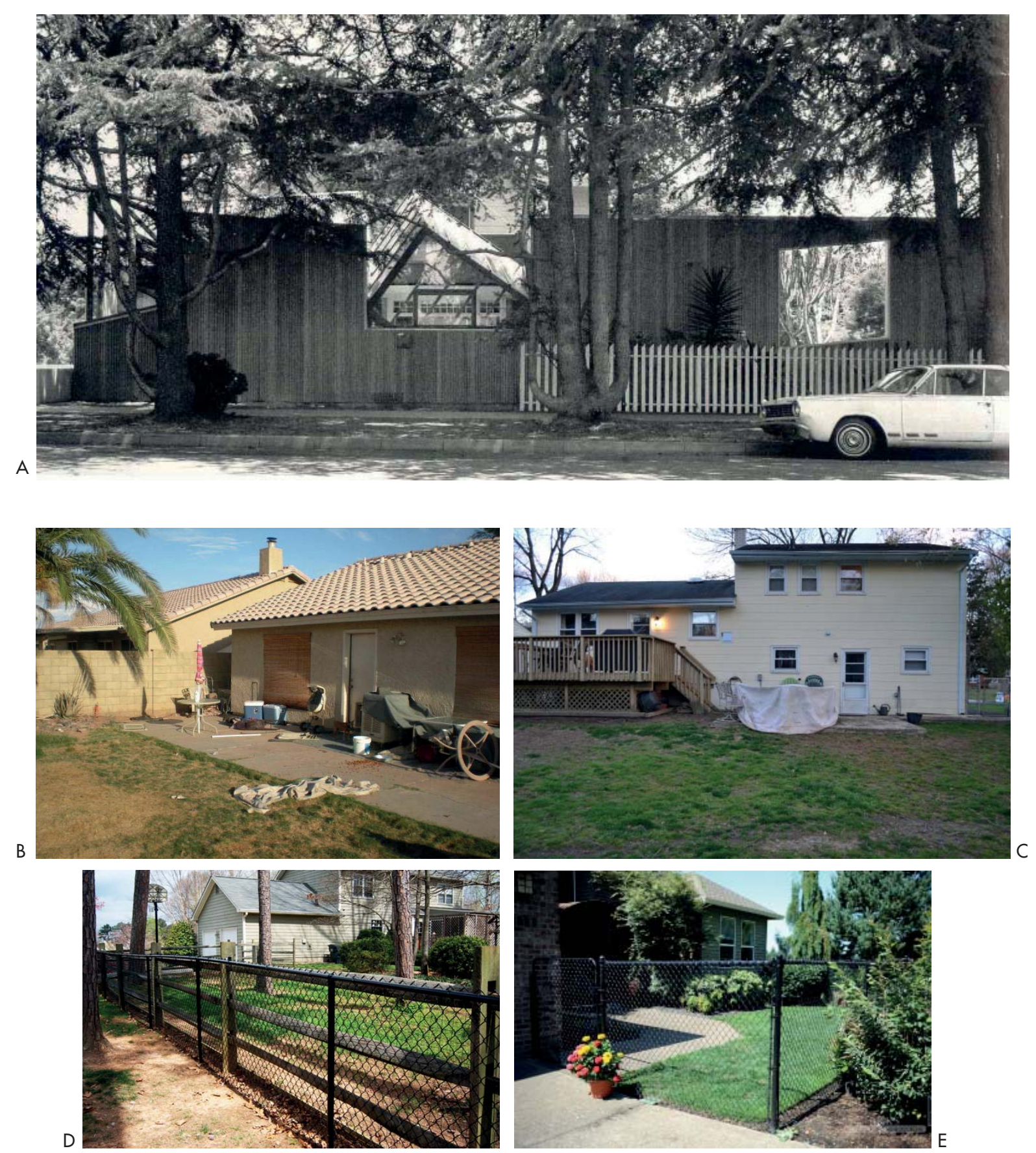
A. Frank Gehry. Santa Monica House (1978) Fachada lateral, años 1980

B-E. Casas americanas. Arquitecto anónimo. vectores nos ayudarán a trazar un mapa de los procesos de innovación que se despliegan en la casa y comprender los desplazamientos que tienen lugar como consecuencia del proyecto.

Afirma Boris Groys que para que un producto cultural- la obra de arte- pueda significar, representar, describir y manifestar la realidad exterior a la cultura, ese producto cultural debe, en primer lugar, distinguirse de esa realidad. ${ }^{179}$ Esa diferencia se puede expresar de muchos modos, pero siempre ha de ser bajo la comparación con lo existente. La diferencia no es lo desconocido. Es, por así decir, lo conocido de una manera nunca vista. Este primer momento es fundamental para la percepción de la obra por que inaugura un tiempo de incertidumbres. Así lo reflejaba Gehry con cierto enfado:

"Me fastidia la conciencia de respetabilidad que impera en los barrios burgueses. Todo el mundo coloca frente a su casa la camioneta o la barca. Hay mucho lío de trastos, chatarra, coches y barcas. Pero mis vecinos me abordan para decirme..."no me gusta su casa", a lo que respondo, "¿Y qué me dice de la barca que tiene en el patio de atrás?, ¿y de su camioneta?, es lo mismo, es la misma estética.” Pero contestan "No, no, eso es normal". Me sorprende que la gente no lo entienda cuando a mí me parece evidente que alguien quiera utilizar un material tan diáfano como la tela metálica." ${ }^{180}$

La extrañeza de la casa era una afrenta para los vecinos. Gehry por el contrario se defiende argumentando que lo que está haciendo es simplemente un desplazamiento de materiales cotidianos y ubicuos a los que nadie presta atención. La malla metálica está por todas partes, argumenta Gehry, no solo en los linderos de los solares vacíos sino también en las pistas de tenis de las casas de los más ricos. La malla forma parte de su vida diaria y en cambio, trasladada de contexto, adquiere una incómoda visibilidad. Como ha apuntado Beatriz Colomina, la afrenta se produce solo porque la casa original sigue allí. Esa proximidad es percibida como violenta por los vecinos:

"Lo que realmente ofende no es simplemente el empleo artístico de materiales no convencionales, sino la persistente presencia de la casa original, atrapada por así decir en un cuerpo extraño. Lejos de ser eliminada o simplemente asaltada, a la casa se la tortura en público. 


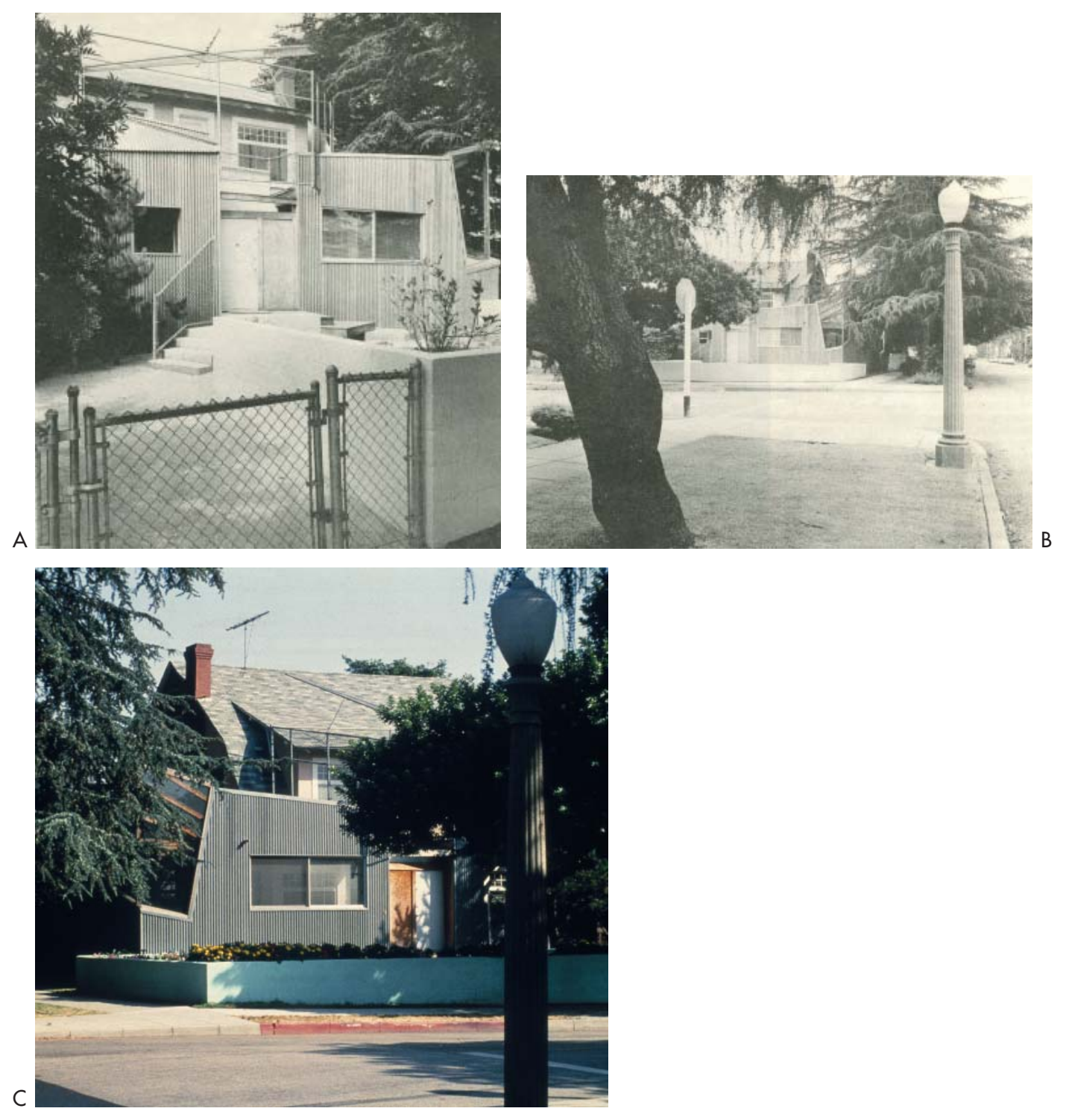


A-C. Frank Gehry. Santa Monica House (1978) Vistas exteriores de la fachada y valla.
181. La cita continua con la reacción de los vecinos: "hubo protestas e intentos de detener las obras por parte de los vecinos, llamadas telefónicas y cartas al alcalde y a los periódicos; un abogado que vivía en la misma calle trató de demandar a Gehry; un arquitecto intentó que el departamento de vivienda lo metiera en la cárcel; Paul Lubowicki, un recién licenciado que trabajaba con Gehry en el proyecto, dice que los vecinos le chillaban; un crítico de arquitectura llevaba a su perro a pasear en el césped; y en dos ocasiones alguien disparó contra una ventana". Colomina, 2007

182. Groys, 2005: 43

183. Groys, 2008: 15
Que permanezca a la vista es lo que provocó las iras de quienes vivían en casas parecidas. Se sintieron atacados ellos mismos." ${ }^{181}$

El cuerpo arquitectónico resultante altera las convenciones y pone en alerta al vecindario. En la transformación de la casa de Gehry no pueden reconocer lo doméstico -lo construido no corresponde con las reformas convencionales de las casa en cualquiera de sus estilos- ni como cotidiano -la propuesta va mucho más allá de poner una valla, un cobertizo de chapa ondulada o cualquier instalación auxiliar en la parcela de la casa-. Lo que produce un verdadero rechazo es que Gehry intercambie los roles y cambie sus jerarquías. Los vecinos advierten la diferencia y expresan su contrariedad. Sin embargo, aquí conviene aclarar un punto fundamental. La casa no se convierte en un objeto innovador por "el empleo artístico de materiales no convencionales" o por que llame la atención a sus vecinos. Con ambas acciones la casa podría solo mostrar la diversidad sin implicar que en si misma propusiera una innovación. O dicho de otro modo: “¿cómo se distingue la diferencia culturalmente valiosa de la diferencia sin valor cultural?". ${ }^{182}$

Aquí es donde la acción de Gehry deja de tener importancia sólo para sí mismo y pasa a ser un asunto de todos, una labor compartida como sociedad. La evidencia de la diferencia y el extrañamiento es lo que moviliza la atención sobre la casa, no solo de los vecinos o de los interesados sino también de las instituciones y agentes que custodian la memoria cultural. Estos, ante la existencia de un principio de contraste estético y en su afán exhaustivo por recolector las manifestaciones de lo vivo, ponen en práctica sus métodos de evaluación y análisis. Comparan la obra con la tradición del archivo para verificar si esta es capaz de ser lo nuevo en el mundo profano. Para el archivo, lo nuevo no sólo consiste en la otredad de una cosa cualquiera, sino sobre todo en su capacidad de representar, al menos durante un tiempo, el entero ámbito profano exterior al archivo, sugiriendo con ello que ha cumplido con aquella vocación de exhaustividad. ${ }^{183}$

A partir de ese momento, se inaugura un nuevo tiempo para la casa de Santa Mónica. El escáner del archivo, incapaz de encontrar en las tradiciones que custodia una "imagen" de referencia que recuerde a la agrupación heterogénea de la totalidad-casa, se ve obligado a incorporarla como una 

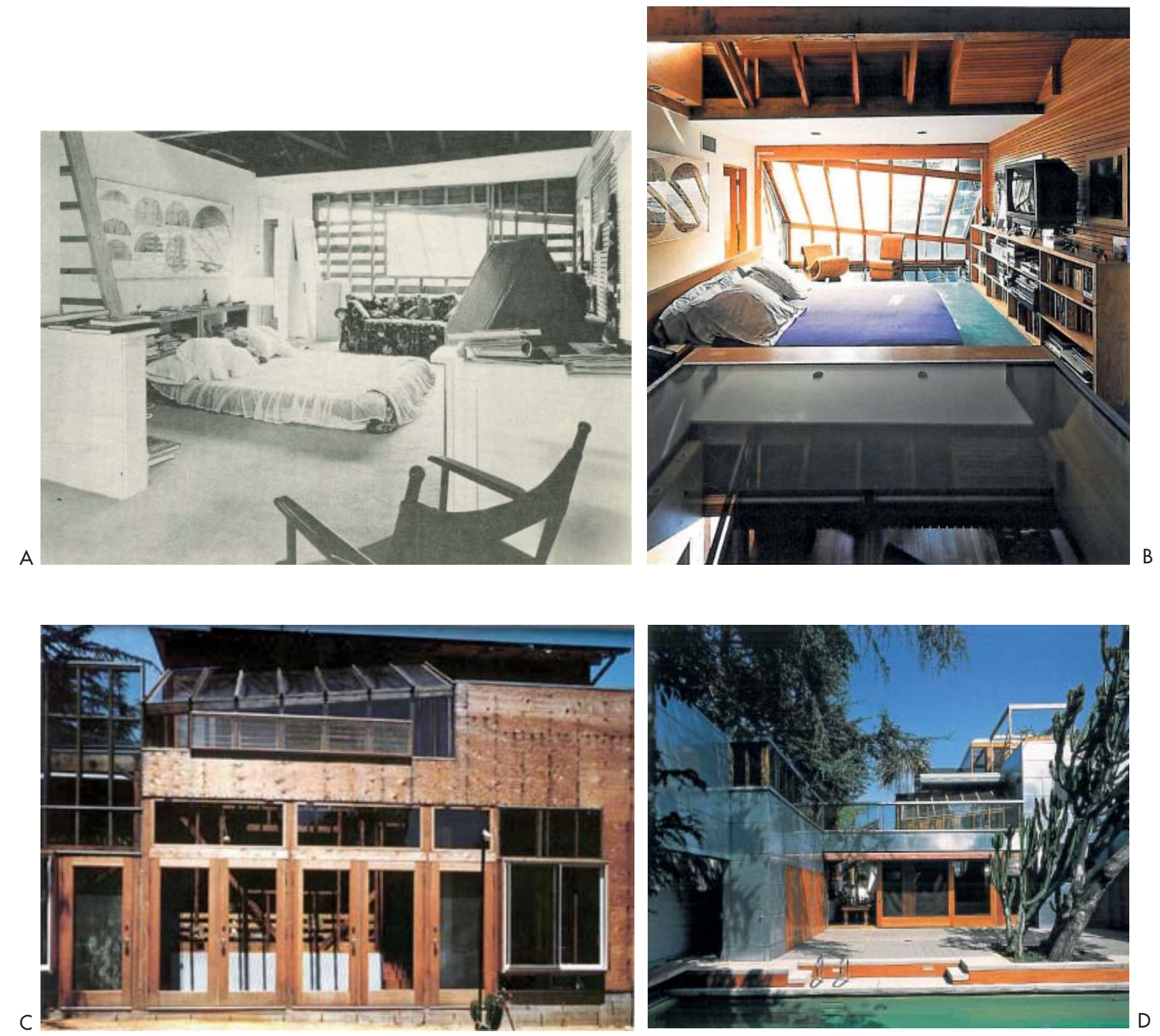
A. Frank Gehry. Santa Monica House (1978) Vista interior de la habitación principal.

B. Frank Gehry. Santa Monica House. Vista interior de la habitación principal, 1982.

C. Frank Gehry. Santa Monica House (1978) Vista exterior desde el patio del cactus y piscina.

D. Frank Gehry. Santa Monica House. Fotografía del exterior con la piscina y el cactus, 1994. representación de lo nuevo, es decir de lo vivo. Podemos decir, por lo tanto, que la innovación se produce en dos etapas: en la primera Gehry propone una trasmutación de significado para su objet trowvé. En la segunda, con la incorporación a los archivos de la cultura se produce su transmutación de valor. El arquitecto propone los desplazamientos pero son los mecanismos del archivo los que, con sus métodos de interpretación -como lo es esta tesis-, valoricen y guarden su memoria.

Sin embargo, aquí surge una de las contradicciones del archivo. Sus limitaciones y la incapacidad de seguir el ritmo de la vida exterior producen siempre un conflicto de representación. ¿Qué se conserva realmente en el archivo? Rara vez en arquitectura, el objeto construido se convierte en sí mismo en parte del archivo. Cuando ocurre pueden conservase a veces como momias, como en el caso de los edificios musealizados; a veces como zombis, edificios protegidos que habitan lo vivo pero se les ha otorgado la categoría de muertos; y otras como fantasmas, como la presencia intuida de lo desaparecido en las ruinas. Sin embargo, en la mayoría de las ocasiones, de lo edificado custodiado en el archivo únicamente se conserva su lectura, su interpretación, su descripción. Mientras tanto, el "original" sigue habitando el mundo de lo real otra vez expuesto a lo vivo y por lo tanto a su transformación.

En este sentido, el caso de Gehry es revelador de los conflictos que tienen lugar en ese espacio intermedio entre lo profano y el archivo: lo más propio de la realidad - esto es, su caducidad- no puede ser reproducido o representado en el archivo. Incluso el arte que pretende escenificar en los espacios del museo su propia caducidad acaba documentado, archivado y custodiado. Para los archivos, la interpretación es la obra. En cambio, la casa real, hace mucho que no se parece a aquella de la que hablan la mayoría de los textos. No se parece tampoco a la que nosotros hemos descrito a lo largo de este capítulo. Esa casa solo existe en los textos y en las imágenes de los repositorios. Hace tiempo que la casa de los archivos se desligó de la casa habitada. De hecho, el propio Gehry reconoce que en el propio proceso de transformación la casa ha perdido muchos de sus valores, y sin embargo, ha ganado en comodidad. La casa ha vuelto a lo profano, mientras su copia "idealizada" ahora ha quedado guardada en los ficheros de lo significado. Y ahí seguirá, parece, por un tiempo. 

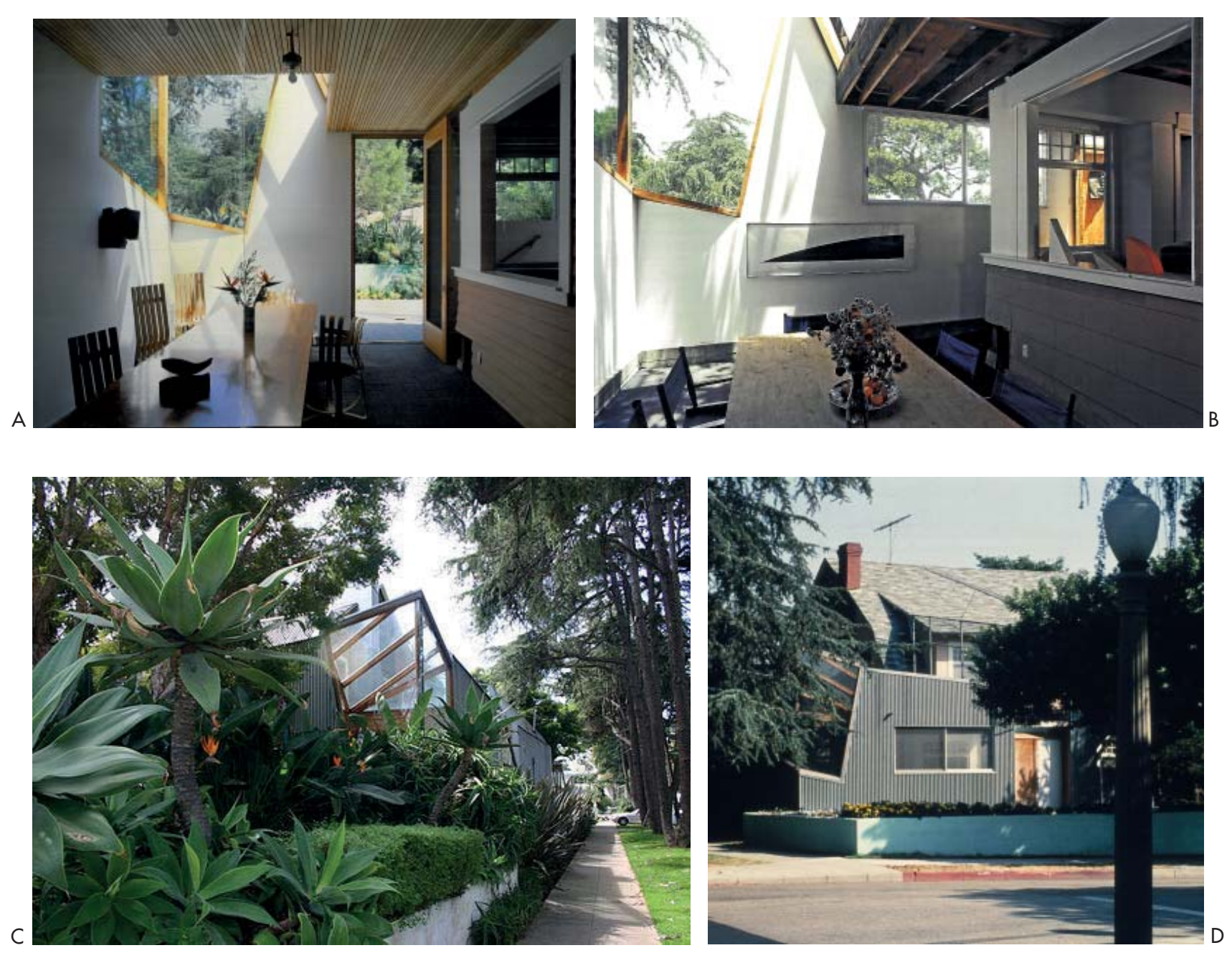
A-B. Frank Gehry. Santa Monica House (1978) Fotografías de la entrada con vistas a la cocina y al comedor.

C-D. Frank Gehry. Santa Monica House (1978) Vistas exteriores.
Desde 1978 la casa ha sufrido varias modificaciones y en cambio, como ha dicho Beatriz Colomina, "la mayoría de los críticos actúan como si nunca hubiera sucedido." ${ }^{184}$ Se sigue hablando de una casa que ya no existe, que ya no está allí.

Ya en 1983, muy poco después de construirla, Gehry soñaba con hacer cambios:

"La casa está completa aunque yo sigo fantaseando sobre ella, como suprimir el interior y sustituirlo por una caja miesiana, y luego demoler el exterior; o terminarla de forma convencional pintándola de rosa y cubriéndola con una capa de yeso. Eso, de alguna manera, me atrae" 185

A pesar del éxito y los elogios que recibió Gehry no tuvo el impulso de congelar la casa. Había sido pensada como un proceso abierto- a work in progress- ${ }^{186}$ y lo continuó siendo. El caso de Gehry, al igual que muchos otros, evidencian una ley de evolución: toda obra inaugura un espacio de posibilidades, con el tiempo esas posibilidades se van matizando, las soluciones se ponen en entredicho, las limitaciones funcionales se van consolidando, el entusiasmo va decreciendo, y la casa es empujada a una nueva mutación.

La lógica de la construcción de la casa-Gehry, inestable y frágil, a medio hacer, era propicia para la transformación en esos términos. Las actuaciones que desplegará en los años por venir son una mezcla de la respuesta a necesidades familiares al mismo tiempo que otra vez una obsolescencia del entusiasmo, esta vez orientada por deseos que provienen desde la prosperidad y el confort. Para 1994 se habían producido cambios sustanciales. Se compartimentaron y aislaron mejor los espacios interiores y la crudeza de los montantes vistos fue sustituida por maderas refinadas y detalles cuidados. Las modificaciones en el exterior fueron aún más radicales. Se abrió una puerta en la parte delantera de la casa junto al comedor, también se cegó la ventana que daba a la Euphoria del patio trasero. Se perdió la conexión con la calle y se hizo un jardín más privado. Los juegos semánticos de la valla se perdieron, desaparecieron las diagonales de los decorados escenográficos y el límite se volvió infranqueable y convencional. En la fachada del patio, la inestabilidad e inmediatez de las carpinterías se sustituyó por robustas puertas de madera y 


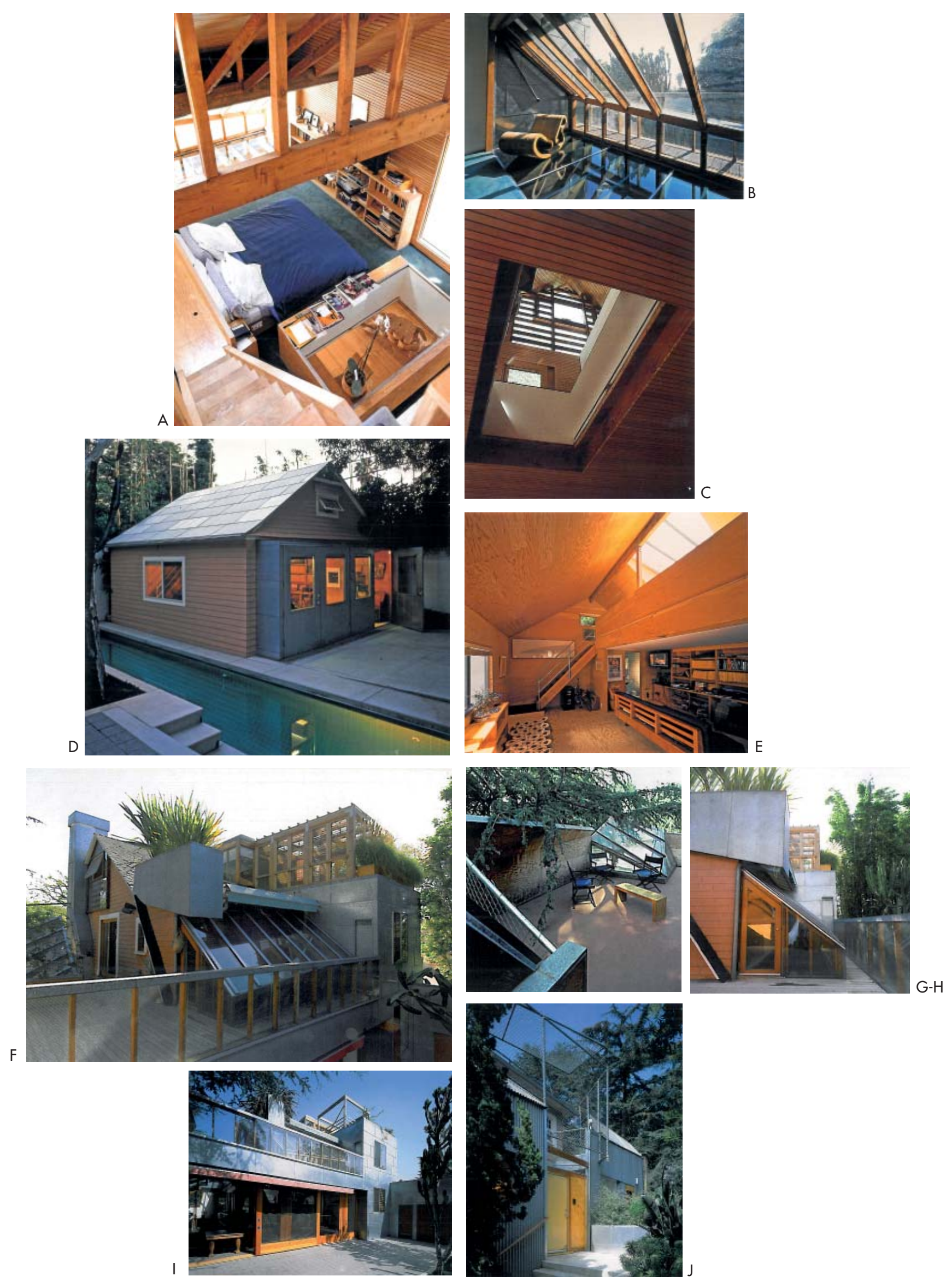


A-C. Frank Gehry. Santa Monica House. Habitación principal, 1994.

D-E. Frank Gehry. Santa Monica House. Interior y exterior del garaje convertido en habitación para invitados, 1994

F-H. Frank Gehry. Santa Monica House. Vistas de las adiciones en la cubierta de la casa, 2006. I-J. Frank Gehry. Santa Monica House. Fotografías exteriores de la casa tras la segunda reforma, 1994. vidrio, los paneles de contrachapado se sustituyeron por aplacados metálicos de fino acabado y las barandillas dejaron de ser de malla para construirse con vidrio. Las comodidades y los deseos omnipresentes de la ciudad de Los Ángeles también penetraron en la casa, decidieron construir una piscina. Sin embargo, como Berta nos advierte, la emoción no dura para siempre: "We all swam in the lap pool, but none of us uses it now." ${ }^{187}$

En una perpetua y humana sensación de hogar incompleto o insuficiente la casa sigue transformándose en su lógica perfeccionista. Años más tarde la familia Gehry compró una parcela cercana para tener más espacio para un jardín más amplio, un garaje y un estudio. Más tarde, entre 2003 y 2007 la casa volvió a sufrir modificaciones, esta vez añadiendo unas terrazas en el piso superior y creciendo en superficie desde la buhardilla. La familia Gehry encargó el paisajismo del porche de acceso a Nancy Goslee Power para suavizar la fachada. El césped marchito de las primeras fotos es sustituido por un bello y exuberante jardín. Gehry explicó así el resultado de su transformación:

"The kids needed bedrooms and stuff, and we had more money to spend. We built a pool. We fixed the roof. We fixed the skylights and the electrical system. A lot was done that unraveled that old house, and I lost it. The house has vestigial reminders of the old strength, but it's not as good as house. It's not as good as piece of art, if you want to call it art, as it was on the first go-round. That's my opinion, although I'm pretty sure it would be shared by others who knew both. But I couldn't do anything about it. I had to lose it because I needed the room for the kids, and there was no way to preserve that original idea without contriving it in a second instance, and I didn't want to do that. So I just charged ahead and took it on the chin. Took one for the team.”188

Gehry reconoce que, tras sus transformaciones posteriores, la casa ya no es una obra de arte singular, tampoco para el archivo parece que las nuevas adaptaciones sean innovadoras y por eso apenas ha hecho esfuerzos por registrarlas. Fueron las necesidades que surgen del mundo de lo profano, de lo vivo, las que obligaron a realizar los cambios. Sin embargo, esta vez, la agrupación heterogénea que constituye la totalidad-casa si está significada. 


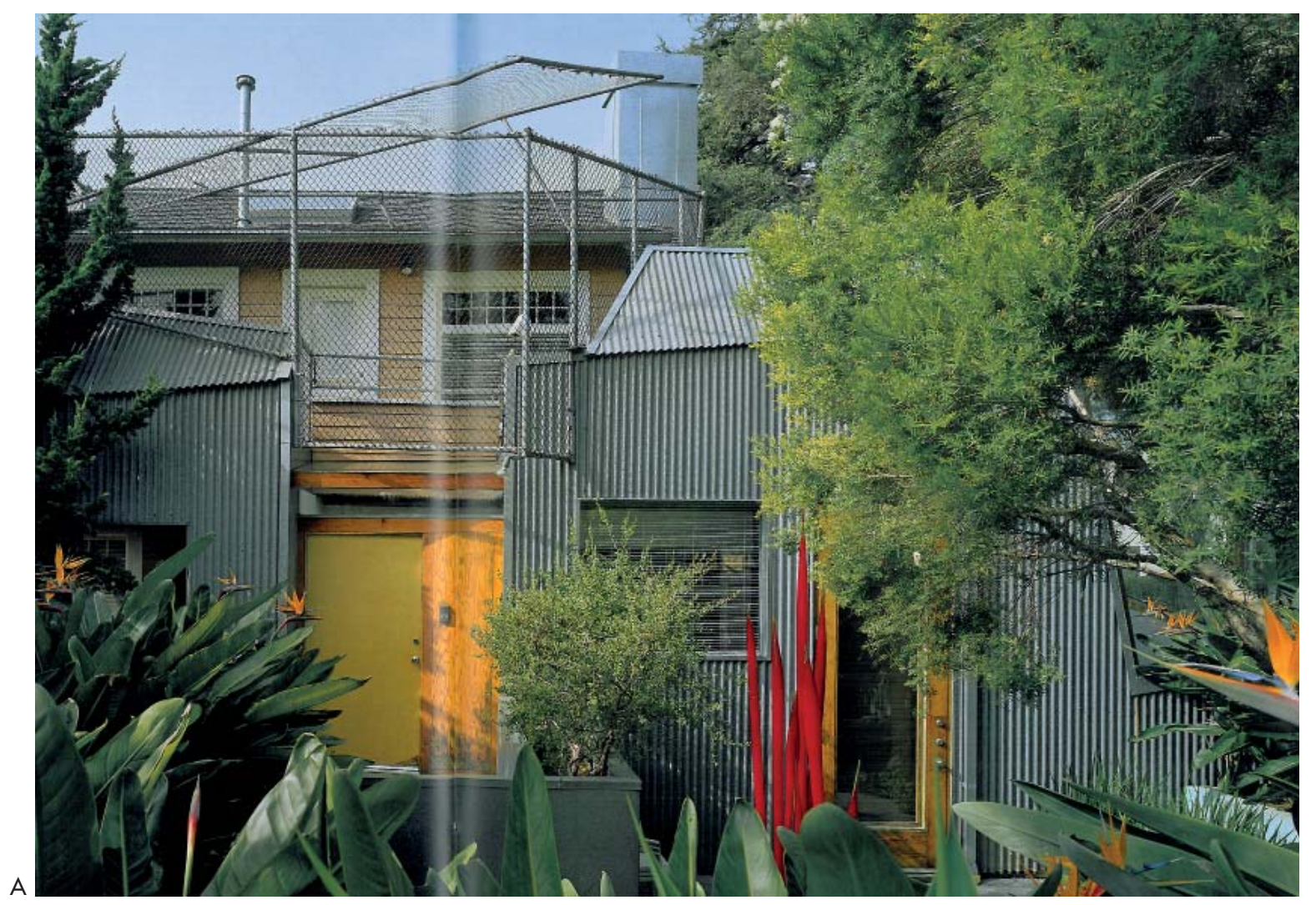


A. Frank Gehry. Santa Monica House. Fotografía de la fachada noreste con vistas del muro rosa de la casa original y la entrada principal debajo 2007.
Ahora la casa tiene otros mecanismos que garantizan su supervivencia y su preservación. La casa de Santa Mónica no es una casa más, ya no es ordinaria. Y por eso ya no tiene sentido que desde aquí la estudiemos más.

En 1978 Gehry se aprovechó de las energías cautivas de la casa-rosa para establecer una transmutación del significado y, a su vez, la casa-rosa se aprovechó de la trasmutación de valor para conservar su materia y viajar en el tiempo. Gehry diseño una estrategia con la que habitar el mundo en lugar de construirlo de cero y la casa-rosa aportó su materia y sus resistencias para que fuera posible. Entre ambos diseñaron una jugada que tiene ya más de treinta y cinco años y en la que somos muchos los que seguimos participando. 

CONCLUSIONES 



\section{CONCLUSIONES}

Llegamos al final de la investigación con la esperanza de haber recorrido los observatorios adecuados para abarcar la región que ocupa nuestra hipótesis de partida. La virtud que tiene enfrentarse a una tarea desde diferentes flancos es que al movernos en torno a ella para tomar nuevas posiciones se producen hallazgos imprevistos. Todo estudio arranca con intuiciones propias y lecturas prestadas, sin embargo, es fácil desecharlas si, según se avanza, se recolectan otras más valiosas que hacen que todo adquiera más sentido y que se explique mejor. Ese ha sido el caso de esta investigación en la que se han revisado las posiciones sostenidas en las diferentes partes de la argumentación y se han replanteado según se iban produciendo nuevos hallazgos. Por ello parece apropiado incluir, en las conclusiones, tanto la comprobación de nuestra hipótesis como los descubrimientos más valiosos y que consideramos también merecedores de otras posibles investigaciones. Las conclusiones se expondrán desde dos perspectivas: Las confirmaciones y los hallazgos. Las confirmaciones agrupan aquellas hipótesis de partida verificadas con nuestra investigación. Los hallazgos son, por el contrario, descubrimientos que el autor considera valiosos para la práctica del proyecto y que quedan enunciados para que él u otros puedan instalar los observatorios apropiados desde los que estudiarlos.

\section{CONFIRMACIÓN DE LAS HIPÓTESIS DE PARTIDA}

La investigación se iniciaba con una afirmación general basada en dos hipótesis parciales. Empezaremos por estas últimas para llegar después a la general.

La primera tomaba como punto de partida la posibilidad de considerar la plastic chair de Charles y Ray Eames como ejemplo paradigmático con el que entender la herramienta proyectual de las agrupaciones heterogéneas. Se ha demostrado, a través de las manifestaciones de sus autores y las lecturas críticas de otros, que puede ser considerada una arquitectura. También ha desvelado que su condición de mobiliario no solo no reduce su capacidad de descripción sino que, lejos de los condicionantes de lo edificado, ayuda a focalizar y condensar con precisión las lógicas de la herramienta proyectual y los posicionamientos teóricos de la que participan. 
La segunda establecía que era posible revertir la obsolescencia de arquitecturas existentes ordinarias cuando estas eran sometidas a ejercicios de transformación no basados en la significación o en aproximaciones exclusivamente cuantitativas. La obra teórica Plus de Druot, Lacaton \& Vassal y su prototipo construido, la torre Bois-le-Pretre nos ha permitido comprobar que dichas obsolescencia eran en realidad agotamientos del entusiasmo. Se ha demostrado que el desplazamiento de imaginarios ilusionantes, al aprovechar las energías cautivas de lo construido, puede invertir el proceso de degradación. Al mismo tiempo, las resistencias de lo construido obligan a los imaginarios a adoptar nuevas e imprevistas configuraciones.

Por último, y como confirmación general, se considera demostrado que es posible revertir la obsolescencia de las arquitecturas existentes ordinaras a través de la técnica proyectual que interviene en la formación de las agrupaciones heterogéneas. Esta acción permitiría a lo construido ordinario continuar su viaje en el tiempo. En el caso estudiado, la casa de Santa Mónica de Frank Gehry, este proceso tiene lugar al constituir un estado de encuentro entre la arquitectura ordinaria y el imaginario heterogéneo desplazado. A través de este acto Gehry propone una trasmutación de significado para su objet trouvé que es capaz, primero, de atraer la atención del archivo al advertir la diferencia con la preexistencia profana, segundo, de ser comparada con sus fuentes para verificar que realmente se ha producido una innovación y, por último, construir en torno a él un andamiaje de teorías que acaben por afianzarlo al archivo. Este proceso garantiza su preservación, como estructura visible de lo ordinario, pero ya desplazada al archivo. La tesis verifica así que en la arquitectura también se cumplen los mecanismo de la innovación de la teoría de la Economía cultural de Boris Groys. Sin embargo, también advertimos que la herramienta de las agrupaciones heterogéneas por sí misma no garantiza la innovación, pues al requerir el escrutinio desde lo colectivo deja de ser un acto individual para construirse como un acto compartido.

Por ello, una vez comprobado el funcionamiento de la herramienta, se propone establecer como punto de partida para otras tesis la necesidad de realizar una genealogía de intervenciones que bajo esta lógica nos den una perspectiva amplia de su aplicación. 


\section{HALLAZGOS}

Los hallazgos, como ya se ha explicado, han sido encuentros o intuiciones que han adquirido forma y se han consolidando en el proceso de esta investigación. Destacamos aquí los más relevantes, aquellos que por sí mismos podrían sostener el cuerpo de una tesis. Son tres: el estado de encuentro de las agrupaciones heterogéneas, la teoría de la resistencia a los imaginarios y las fuentes de Gehry

\section{El estado de encuentro de las agrupaciones heterogéneas}

Las agrupaciones heterogéneas son el resultado de la coexistencia de dos o más sistemas diferenciados entre los que se manifiesta una tensión. Es un cuerpo arquitectónico en el que se da una relación entre distintos sin subordinación o jerarquías. Al carecer de la uniformidad de lo homogéneo sus partes están condenadas a ser continuamente revisitadas ya sea para localizar sus diferencias o para reconocer sus parecidos. Este estado de indeterminación demanda una percepción activa y crítica. Las agrupaciones heterogéneas son, por la lógica del montaje con la que han sido construidas, una duración. O por decirlo de otra forma, un estado de encuentro. Tanto en la plastic chair como en la casa de Santa Mónica de Frank Gehry hemos descubierto la riqueza de interpretaciones que proporciona mirar atentamente a ese estado de encuentro y que nos permite dejar de ver los objetos como monótonamente continuos para descubrir en ellos visiones encontradas del mundo.

\section{Teoría de la resistencia a los imaginarios}

$\mathrm{Al}$ actuar sobre una arquitectura existente se pone de manifiesto que lo construido ordinario no se comporta como un material inerte y homogéneo sino que se comporta como un conjunto estratificado cuya resistencia al cambio es variable. Partiendo de la teoría de las Shearing layers of change de Stewart Brand hemos llegado a la conclusión de que la resistencia a los imaginarios depende, por un lado, de la función y la posición que ocupa dentro del sistema de estratos del edifico y, por otra, de la capacidad de participar de la red de afectos de sus habitantes. El potencial de la arquitectura existente de recibir nuevos imaginarios estaría condicionada por esas variables de resistencia. 
La torre Bois-le-Prêtre y la casa de Santa Mónica de Gehry nos han ofrecido la posibilidad de profundizar en el salto entre el imaginario desplazado y su nueva configuración. Otras investigaciones posibles y necesarias serían aquellas que evalúen qué imaginarios han sido utilizados en otros casos de la intervención sobre lo existente ordinario y cómo se comportan bajo la teoría enunciada.

\section{Las fuentes de Gehry}

Este quizá sea el hallazgo más concreto de esta investigación, pero sin embargo, no por ello debería considerarse menor. Cualquier visión que arroje nuevas posibilidades de interpretación sobre la obra de un arquitecto reconocido es recomendable para volver a reivindicar su valor. Como en muchas otras lecturas precedentes de la obra de Gehry estábamos convencidos de que la aproximación más adecuada para entender la casa de Santa Mónica estaba en entender la influencia del arte y de sus amigos artistas como fuente del proyecto. Sin embargo, fue al entrar en profundidad en el tema y recorrer el trabajo de Gehry sin prejuicios, cuando nuevas perspectivas alumbraron otra posible interpretación: la arquitectura de Gehry podría también entenderse desde las arquitecturas de la ficción del centro comercial. Los años de colaboración junto a Victor Gruen le habrían dado a Gehry unas herramientas, denostadas por muchos críticos, para producir una arquitectura de las experiencias y de la ficción. Esta tesis reconoce su incursión limitada en este descubrimiento al ser tangencial a su campo de trabajo pero el autor considera necesario y relevante realizar una lectura de la primera obra de Gehry bajo esta perspectiva.

Quedan así aquí recogidas las conclusiones y hallazgos principales, sirvan todas ellas para seguir haciendo arquitectura. 


BIBLIOGRAFIA 



\section{BIBLIOGRAFÍA}

VV.AA. (1979) "Building of the Quarter. The Gehry House, per Voco" en Archetype, 2. pp. 23-28.

ÁBALOS, I. y SENTKIEWICZ, R., (2015) Dualisms. Exbibition catalogue. Cambridge, Department of Exhibitions, Harvard GSD.

ÁBALOS, I., (2012) "Una cartografía imaginaria" en 2G: Revista Internacional De Arquitectura, 60, pp. 4-16.

ALBRECHT, D., (1997) The work of Charles y Ray Eames: a legacy of invention. Nueva York, Harry N. Abrams.

ALEXANDER, C.J., (2010) Los Ángeles de Julius Shulman. Madrid, Comunidad de Madrid.

ARNELL, P., BICKFORD, T., y GEHRY, F.O., (1985) Frank Gehry: buildings y projects. Nueva York, Rizzoli.

BOISSIÈRE, O., (1981) Gehry, Site, Tigerman: trois portraits de l'artiste en architecte. Paris, Cep Editions.

BOURRIAUD, N., (2004) L'esthétique relationnelle. Dijon, Les Presses du réel. Traducción al castellano BOURRIAUD, N., (2006) Estética relacional. Buenos Aires, Adriana Hidalgo.

BRAND, S., (1994) How buildings learn: what happens after they're built. London, Phoenix illustrated.

CAPLAN, R., (1976) Connections: The Work of Charlesy Ray Eames. Los Angeles, UCLA Art Council.

CHOAY, F., (2007) Alegoría del patrimonio. Barcelona, Gustavo Gili.

COBB, H., (1986) The Architecture of Frank Gehry. New York, Rizzoli. Traducción al castellano COBB, H., (1988) La arquitectura de Frank Gehry. Barcelona, Gustavo Gili. 
COLOMINA, B., (2007) "Reflexiones sobre la casa Eames" en Revista de Arquitectura, 9, pp. 3-16.

- (2006) Doble exposición: arquitectura a través del arte. Madrid, Akal.

- (2003) “Una conversación con Frank Gehry” en El Croquis, 117, pp.6-34.

- (2001) "Enclosed by images: the Eameses' multimedia architecture" en Grey Room, 02, pp. 7-29.

CRAWFORD, M. (1992) “The World in a Shopping Mall” en SORKIN, M. (Ed.) (1992) Variations on a Theme Park: The New American City and the End of Public Space. New York, Hill and Wang.

CURTIS, W. (2006) La arquitectura moderna desde 1900. Londres, Nueva York, Phaidon.

DALCO, F., (1998) Frank O. Gehry: the complete works. New York, Monacelli Press.

DANA, K., (2011) “A propósito de Lacaton \& Vassal, una tentativa de voz en off” $2 G, 60$, pp. 17-25.

DEMETRIOS, E., (2001) An Eamesprimer. New York, Universe Publications.

DEPARTMENT OF ECONOMIC Y SOCIALAFFAIRS, POPULATION DIVISION, UNITED NATIONS, (2014) World Urbanization Prospects: The 2014 Revision, Highlights (ST/ESA/SER.A/352). 2014 edn. Nueva York, United Nations.

DIAMONSTEIN-SPIELVOGEL, B., (1980) “Frank O. Gehry” (entrevista) en American Architecture Now. Nueva York, Rizzoli.

DIAZ MORENO, C. y GARCÍA GRINDA, E., 2015. "Placeres cotidianos: una conversación con Anne Lacaton \& Jean Philippe Vassal" en el Croquis, 177, pp. 5-31.

DIDI-HUBERMAN, G., (2010) Atlas, ¿Cómo llevar el mundo a cuestas? Madrid, Museo Reina Sofia. 
DOUGLAS, J., (2006) Building adaptation. Amsterdam; Boston; London, Butterworth-Heinemann.

DROHOJOWSKA-PHILP, H., (2011) Rebels in Paradise: The Los Angeles Art Scene y the 1960s. Nueva York, Macmillan.

DRUOT, F., LACATON, A. y VASSAL, J., (2012) Tour Bois Le Prêtre. Ilka \& Andreas Ruby (eds.). Frankfurt, Ruby Press

- (2007) Plus, la vivienda colectiva: territorio de excepción = les grands ensembles de logements: territoire d'exception = large-scale housing developments: an exceptional case. Barcelona, Gustavo Gili.

- (2004) Étude Plus. [online] calameo.com. Accesible en: http://es.calameo. com/read/000002636b63c2f73a01c [último acceso 25 Noviembre de 2015].

DUFFY, F. y DEGW, L.L., (1998) Design for change: the architecture of DEGW. Basel; Boston, Haslemere, Birkhäuser; Watermark.

EAMES, C. y EAMES, R., (2015) An Eames Anthology: Articles, Film Scripts, Interviews, Letters, Notes, y Speeches. New Haven, Yale University Press.

FERGUSON, H., (2010) La pasión agotada: estilos de vida contemporánea. Buenos Aires; Madrid; Barcelona: Katz; Cccb.

FORSTER, K.W. y GEHRY, F.O, (1999) Frank O. Gebry - Kurt W. Forster. Cristina Bechtler (ed.). Ostfildern-R., Cantz.

FOSTER, H., BOIS, Y., KRAUSS, R.E. y BUCHLOH, B.H., (2006) Arte desde 1900. Madrid, Ediciones AKAL.

FRAMPTON, K., (1995) American masterworks: the twentieth-century house. New York, Rizzoli.

FRIEDMAN, M., (2009) Frank Gehry. The houses. New York, Rizzoli.

GARCÍA VÁZQUEZ, C., (2004) Ciudad hojaldre: visiones urbanas del siglo XXI. Barcelona, Gustavo Gili. 
GARDNER, J.E., (1989) "Decision making for sustainable development: Selected approaches to environmental assessment y management" Environmental Impact Assessment Review, 9, pp. 337-366.

GEHRY, F.O., (2004) Gehry draws. Cambridge, MIT Press \& Violette Editions.

- (1980) “Architect’s house, Santa Monica, California, 1978; architects: Frank O. Gehry y Associates" Architecture \& urbanism, 7, pp. 3-14.

- (1979a) "Frank O. Gehry: Gehry residence, Santa Monica, California, U.S.A., 1979" en GA bouses, 101, pp. 88-91.

- (1979b). "Suburban Changes: Architect's House, Santa Monica 1978)" en International Arcbitect (U.K.), 1, pp. 33-46.

GEORGESCU-ROEGEN, N., (1996) La ley de la entropía y el proceso económico. Madrid, Fundación Argentaria; Visor.

GIEDION, S., (1967) Space, time and architecture: the growth of a new tradition. Cambridge, Harvard University Press. Traducción al castellano, GIEDION, S., (2009) Espacio, tiempo y arquitectura: origen y desarrollo de una nueva tradición. Barcelona, Reverté.

GINGERICH, O. y EAMES, C., (1977) "A Conversation with Charles Eames"en The American Scholar, 46, pp. 326-337.

GLISSANT, É., (2002) Introducción a una poética de lo diverso. Barcelona, Ediciones del Bronce.

GOLDBERGER, P., (2015) Building Art, The Life y Work of Frank Gehry. Nueva York, Alfred A.Knopf.

GOLLNER, A., (2005, 20 de Marzo) Gander Airport: When the Going was Good. The New York Times.

GOULET, P., LACATON, A. y VASSAL, J., 2010. "Dos conversaciones con Patrice Goulet” en $2 G$, pp. 130-155. 
GROYS, B., (2008) Bajo sospecha. Una fenomenología de los medios. Valencia, Pretextos.

GROYS, B., (2005) Sobre lo nuevo: Ensayo de una economía cultural. Valencia, Pre-textos.

GUASCH, A.M., (2011) Arte y archivo, 1920-2010: genealogías, tipologias y discontinuidades. Tres Cantos Madrid, Akal.

HERREROS, J., 2015. "Nada excepcional: siete acciones revisitadas en la obra de Lacaton \& Vassal” en el Croquis, 177, pp. 360-369.

ISENBERG, B.S., (2009) Conversations with Frank Gebry. Nueva York, ST. Martins Griffin.

JENCKS, C., (1993) Heteropolis: Los Angeles, the riotsy the strange beauty of heteroarchitecture. London; Berlin, Academy; Ernst \& Sohn.

KEPES, G., (1944) Language of vision. Chicago, Paul Theobald.

KIRHAM, P., (1995) Charles y Ray Eames: designers of the twentieth century. Cambridge, MIT Press.

KOOLHAAS, R., (2006) La ciudad genérica. Barcelona, GG minima.

KUBLER, G., (1962) The shape of time; remarks on the history of things. New Haven, Yale University Press. Traducción al castellano: KUBLER, G., (1988) La configuración del tiempo: observaciones sobre la historia de las cosas. Madrid, Nerea.

LABARTA, C., (2012) "Revisitando a Schindler, comprendiendo a Gehry. Los ángeles 1921-1978” en Revista de Arquitectura, 14, pp.71-80

LACATON, A. y VASSAL, J., (2015) Lacaton \& Vassal, 1993-2015: horizonte post-mediático $=$ post-media horizon. El Escorial Madrid, El Croquis.

- (2011) “La libertad estructural, condición del milagro.” en 2G, 60, pp. 162175

LAI, C.C., (1999). Charles Eames y Communication: From Education to Computers. Cambridge, Massachusetts Institute of Technology. 
LANGARITA, M. y NAVARRO, V., 2015. “Trabajar con máquinas del tiempo" en 2G, 70, pp. 161-165.

- (2011) “Amueblar el mundo” en Quaderns, 262, p.20.

LATHAM, D., (2000) Creative re-use of buildings. Shaftesbury, Donhead.

MANSILLA, L.M., (2002) Apuntes de viaje al interior del tiempo. Barcelona, Fundación Caja de Arquitectos.

MILLER, R., (1990) “The Master of Mud Pies” en Interview 20, 1 p.46.

MASON, R., 2004. "Fixing Historic Preservation: A Constructive Critique of 'Significance"' en Places, 16, pp. 64-74.

MOHOLY-NAGY, L., (1965) Vision in motion. Chicago, Paul Theobald.

MONEO, R., (2004) Inquietud teórica y estrategia proyectual en la obra de ocho arquitectos contemporáneos. Barcelona, Actar.

NAVARRO, V., 2014. "Plastic Furniture: las sillas-mundo" en REIA, 2, pp. 115-126.

NEUHART, J., EAMES, R. y NEUHART, M., (1989) Eames design: the work of the office of Charlesy Ray Eames. New York, Abrams.

NEUHART, M. y NEUHART, J., (2010) The story of Eames furniture. Berlin, Gestalten.

NEUHART, J., NEUHART, M., CAPLAN, R., (1976) Connections: The Work of Charles y Ray Eames. Los Angeles, Frederick S. Wight Art Gallery.

PALLASMAA, J., (2012) Frammenti: collage e discontinuità nell'immaginario architettonico. Pordenone, Giavedoni.

PETZET, M., HEILMEYER, F., (2012) Reduce, Resue, Recycle: Architecture as Resource. German Pavilion, 13th international Architecture Exbibition La Biennale di Venezia 2012. Osfildern, Hatje Cantz Verlag.

RAMÍREZ, J.A., (2000) Duchamp: el amory la muerte, incluso. Madrid, Siruela. 
RIVKIN, A., (2015) "Espaciar: el horizonte post-mediático de la obra de Lacaton \& Vassal" en El Croquis, 177, pp. 33-47.

ROWE, C. y KOETTER, F., (1978) Ciudad collage. Barcelona, Gustavo Gili. RUBINO, L., (1984) Frank O. Gehry special. Roma, Kappa.

RUBY, I. y RUBY, A., (2004) The challenge of suburbia. London, Wiley-Academy.

- (2002. "Naïve architecture: Notes on the Work of Lacaton \& Vassal" en 2G, 21, pp. 4-19.

SCHRADER, P., 1970. "Poetry of Ideas: The Films of Charles Eames" Film Quarterly, pp. 2-19.

SCOTT, T. y WESTEROTH, E., (2014) A Homage To Modern Design. Disponible en: http://www.xtcdesign.com/blog/a-homage-to-modern-design/

SEMES, S.W., (2009) The future of the past: a conservation ethic for architecture, urbanism, y historic preservation. New York, W. W. Norton \& Company.

SHIELDS, J.A.E., (2014) Collage y architecture. New York, Routledge.

SMITHSON, A. y SMITHSON, P., (2001) Cambiando el arte de habitar: Piezas de Mies, Sueños de los Eames, Los Smithsons. Barcelona, Gustavo Gili.

- (1966) “Eames Celebration” en Architectural Design, September.

SORKIN, M., et al. (1992) Variations on a Theme Park: The New American City and the End of Public Space. SORKIN, M. (Ed.) New York, Hill and Wang

TAINTER, J.A. y LUCAS, G.J., (1983) "Epistemology of the Significance Concept” American Antiquity, 48, pp. 707-719.

TAYLOR, A.J., (2014) Forms of Persuasion: Art and Corporate Image in the 1960s. Oxford, University of Oxford.

WALDMAN, D., (1992) Collage, assemblage y the found object. New York, Harry N. Abrams. 
WALKER, E., (2010) Lo ordinario. Barcelona, Gustavo Gili.

WARHOL, A., (2011) America. London, Penguin.

- (1998) Mi filosofía de A a B y de B a A. Barcelona, Tusquets Editores.

WILKINSON, S., (2014) Sustainable building adaptation: innovations in decisionmaking. Oxford, Wiley Blackwell.

\section{VIDEOGRAFÍA}

HLM, Habitations Légèrement Modifiées (2013) documental dirigido por Guillaume Meigneux, Francia, Cellulo Prod e Interland Films 

